REPORT ON SURVEY OF LAND AND WATER RESOURCES

AFGHANI STAN

VOLUME - II

SECTION I - GEOLOAY

SECTION II - TOPOARAPHIC SURVEYS

FOOD AND AGRICULTURE ORGAIIIZATION OF THE UNITED NATIONS UNI TED NATIONS SPECIAL FUND ROME 1965 


\begin{tabular}{|c|c|c|}
\hline VOLUME I & QENERAL RHPORT & N.D. TKACHEV AND \\
\hline VOLUME II & $\begin{array}{l}\text { SECTION I - OEOLOOY } \\
\text { SECTION II - TOPOGRAPHIC SURVEYS }\end{array}$ & $\begin{array}{l}\text { J.B. AUDEN } \\
\text { A.E. PALLISTER }\end{array}$ \\
\hline VOLUME III & HYDROLOGY & A.P. JIDIKOV \\
\hline VOLUME IV & SOILS AND LAND CLASSIFICATION & $\begin{array}{l}\text { V.S. SUBRAMANIAN } \\
\text { Y.M. N.ASSYROV } \\
\text { K.N. SATYAPAL } \\
\text { R.G. MENON }\end{array}$ \\
\hline VOLUME: V & $\begin{array}{l}\text { WATER CONTROL, IRRIGATION } \\
\text { AND POWER }\end{array}$ & $\begin{array}{l}\text { Q.N. EREMEEVV AND } \\
\text { I.P. AKSAKOVSKY }\end{array}$ \\
\hline VOLUME VI & $\begin{array}{l}\text { IRRIQATION DEVELOPMENT - } \\
\text { HARI RUD AND KABUL BASINS }\end{array}$ & I.P. AKSAKOVSKY \\
\hline
\end{tabular}

Eaoh Volume contains its own Table of Contents, inoluding Appendioes, and a list of the Maps and Drawings attached to it. 
$\Delta f_{8}$

Alluvium

Bed Load

Catohment Area

Colluvium

Dead Storage

Orose Heotares

Ha.

Hydromorphio

Karez

$\mathbf{K W}$

I/seo.

Loes8

$\mathrm{M}^{3} / \mathrm{S} \odot$ o.

M.S.I.

Monsoon (India)

Net Heotares
Afghani, equal (1964) to about 0.022 US\$

Soil material deposited by water.

Coarse sediment rolled down stream bed by flow of water.

The area from whioh surface flows are tributary to a river at any particular point.

Detritus accumulated at the foot of a steep slope.

Storage capacity in a reservoir not available for effective use, which may be because it is below the outlet level or because it is silted up, or liable to siltation, eto.

Total area of lands within the outer limits of an irrigation scheme.

Hectare - 10,000 sq. metres.

Soil condition developed with excessive water.

Unlined tunnel in hillside, bringing water by free flow from underground acquifers for surface irrigation. Dug by local craftsmen from shafts at close intervals, they are small in dimensions but may be many kilometres in length.

1 Kilowatt $=1,000$ Watts $=1.34$ British horsepower.

Litres per second. 1,000 Litres $=1$ cubic metre.

Fine sediment, in general deposited by wind.

Cubic metres per second.

Height (metres) above Mean Sea Level.

Summer season of heavy rains.

Area of lands within an irrigation scheme, on which crops can actually be grown, i.e. excluding areas occupied by canals, drains, roads, villages etc. (In this Report tentatively assumed at 0.88 of Gross Hectares, but this proportion may vary over a considerable range). 
Piedmont

Plaoe Namer

Probability

Sediment Discharge

Sierozem

Solonohak

Speoif'ic Index

Suspended Load

Talus

Ton

V.I.

Wadi

Water Control Coefficient

Watiershed
Land of moderate or gentle slope at the foot of a range.

There is no otandard authority in Afghanistan in this matter. In the preparation of this Report, slishtly different spellings of the same place names, have been used in different volumes, and it has not been possible to make all these uniform. It is believed, however, that this will not cause any confusion

The expression a "year of X\% probability" is discussed in Volume III - Hydrology, Chapter 5. In effect, in this Report it is taken to mean a year such that its discharge (whether mean, maximum or minimum) will probably be reached or exceeded in $X$ years out of 100 . For example, a year of $75 \%$ probability is a low year, below the average; a year of $20 \%$ probability is a high year above the average.

Amount of solid matter moved by the flow of a stream or river.

Gray desert soil overlying calcareous layer

Saline soil, without structure

Quantity per Unit of Area, e.g. Run-off in $\mathrm{L} / \mathrm{sec} / \mathrm{hectare}$ or Cost or Value in Afg/hectare.

Finer sediment carried in suspension by flow of water in stream.

Detritus accumulated at the foot of a steep slope.

In this Report is Metrio Ton of 1,000 kilogrammes

Vertical interval between contours.

Stream course, small or large, normally dry but subject to flows which may be sudden, large, fast, and laden with silt and debris.

Ratio of net effective storage capacity of a reservoir to the amount of the annual flow reaching it.

The line of higher ground forming the boundary between two adjacent catchments. 


\section{VOLUME II : SECTION I}

a EOLOOY

Chapters

Part 1

Regional Setting

$1-7$

Introduction

Functions of a Geological Survey in Engineering Projects

General Geology

Tectonios

Seismicity of Afghanistan

Silt Content of Rivers

Karstic Conditions

1

2

3

4

5

6

7

Projects on the Farah Rud

Previous Investigations

General Geology

Dam-Site and Reservoir Topography

Bakhshabad Dam Site

Aliki Nai Dain Site

12

Lashkar Ghar Dam Site

Conditions of Watertightness in the three reservoir basins

Tabulated Comparison between three projects

Lower Farah Rud

Projects on the Hari Rud

Hari Ruà Valley

Salmah Dam Site

Assarisum and Tasra Kai Dam Sites

19

Tangi Shah Dam Site

20

Tangi Azao Dam Site.

21

Marwa Weir Site : Pashdan Dam Site

22

Hari Rud Valley below Obeh

23

Adraskand and Kash Rud

$24-25$

Adraskand

24

Kash Rud

Kabul River System

General Description Kajao Dam Site: Logar River

'Tangi Saidan Dam Sites Bala Maidan River including Report by J.P. Hunger 
Volume II - Section 1

Part I

II

III

V

VI

Regional Setting

Map 1 Afghanistan : Key Map

2 Major Faults in Southern Afghanistan and Contiguous Countries

3 Seismic Map of parts of Asia, based on maps of Gutenberg, Richter and Vvedenskaya, with additions.

4 Photo-geological Interpretation of a Part of NorthWestern Afghanistan, checked by local traverses on the ground

Farah Rud

5 Geological Map of the Bakhshabad Dam Site

6 Geological Map of the Bakhshabad Area

7 Geological Map of the Aliki Nai Dam Site

8 Geological Map of the Aliki Nai Area

9 Geological Map of the Lashkar Ghar Dam Site

10 Geological Map of the Lashkar Ghar Area

Hari Rud

11 Outline Map of the Upper Hari Rud and Kawgan Tributary showing basins and faults, based on uncontrolled Photo-Index Mosaics

12 Geological Map of the Salmah Dam Site

13 Geological Map of the Asarisum Dam Site

14 Geological Map of the Pasra Kai Area

15 Geological Map of the Tangi Shah Dam Site

16 Geological Map of the Tangi Shah Area

Kabul River

17 Geological Map of the Kajao Dam Site, Logar River

18 Geological Map of the Tangi Saidan Dam Site, Bala Maidan River (by J.P. Hunger)

\section{Katawaz}

19 Preliminary Geological Map of a part of Katawaz, Ghazni Province 


\section{CONTENTS}

Chapter 1. INTRODUCTION

\section{Dates}

Status of Topographioal Mapping

Status of Geological Surveys

Seismic Information

References

Accessibility

Acknowledgments

2. FUNCTIONS OF A GEOLOGICAL SURVEY

IN ENGINEERING PROJECTS

General Procedures

Sequence of Investigations in Afghanistan

3. GENERAL GEOLOGY

Different Areas

The Cuestion of a Basement

Ubiquitous Flysch

Metamorphism of Flysch

Cretaceous Limestone

Formations below the Limestone

Post-Cretaceous Erosion

4. TECTONICS

The Main Units

Extensive Fault System

Convergence of Fault System

General Tectonic Framework

5. SEISMICITY OF AFGHANISTAN

Historical Data

Seismic Map

Seismic Zones

Position of Afghanistan

6. SIIT CONTENT OF RIVERS

7. KARSTIC CONDITIONS
$1-15$

$1-3$

$4-5$

$6-13$

$14-15$

16

$17-20$

$21-25$

$1-15$

$1-8$

$9-15$

$1-28$

$1-2$

$3-8$

$9-13$

$14-18$

$19-22$

$23-26$

$27-28$

$1-18$

$1-5$

$6-14$

$15-17$
18

$1-22$

1
$2-\quad 5$

$6-13$

$14-23$

$1-11$

$1-10$ 


\section{Maps}

Map I

Afthanistan: Key Map

Major Faults in Southern Afgnanistan and Contiguous Countries

Seismic Map of parts of Asia, based on maps of Gutenberg, Richter and Vvedenskaya, with additions.

Photo-geological Interpretation of a Part of North-Western Afghanistan, checked by local traverses on the ground. 
CHAPTER 1 - INTRODUCTION

1.1 The following account is conoerned with geological investigations in connection with dam sites, reservoir basins and groundwater carried out in collaboration with members of the Land and Water Resources Survey, U.N. Special Fund, Afghanistan.

1.2 The geologioal work was undertaken during three periods as follows:-

September 1960 to May 1962

August to October 1962

Mid-June to mid-August 1963.

1.3 The following rivers and areas were studied:-

$\begin{array}{ll}\text { Farah Rud } & 1960,1961,1962 \\ \text { Hari Rud } & 1961,1963 \\ \text { Kawgan } & 1961,1962 \\ \text { Adraskand } & 1961,1963 \\ \text { Logar } & 1962,1963 \\ \text { Bala Maidan } & 1962,1963 \\ \text { Panjshir Ghorband } 1962 \\ \text { Katawaz } & 1962\end{array}$

Status of Topographical Mapping

1.4 Until near the end of work on the Project in Afghanistan, the only maps which were available were the Survey of India "Quarter-inch". $(1: 253,440)$ reconnaissance sheets of the country. These maps; although quite lacking in detail, are for the most part astonishingly accurate regarding the positions of mountains, river confluences and villages.

1.5 The whole of Afghanistan was covered by aerial photography between 1957 and 1959. The northern part was photographed by Soviet agencies. The southern twothirds of the country were flown by Fairchild. Copies of the Soviet photographs could be consulted in Kabul, but were not available for use in the field. The Special Fund team was able, however, to obtain copies of the Fairchild photographs for field use. In the main, photography with cameras of 6-inch $(15.24 \mathrm{~cm}$.) focal length was used, but for some purposes 12-inch $(30.48 \mathrm{~cm}$.) photography was preferable.

By the middle of 1962 advance copies of the topographical maps based on the aerial photography, on the scale of 1:50,000, gradually became available for some of the areas with which the team was concerned.

Status of Geological Surveys

1.6 The area of Afghanistan is approximately $650,000 \mathrm{Km}^{2}$. Much of this area is mountainous, with peaks rising to $6940 \mathrm{~m}$. in the Wakhan, and $6040 \mathrm{~m}$. in Afghanistan proper, and is difficult of access. Historical reasons have resulted in the country for long having been closed to normal travel. Such earlier topographic and geological work as was done was mainly from British-Indian sources. 
1.7 Various traverses were made by ariesbach and Hayden, of the Geologioal survey of India, between 1880 and 1913 in parts of southern and northern Afghanistan. In 1940-42 W. D. West, also of the Geological Survey of India, undertook an important detailed survey of coal measures in the Ishpushta area.

1.8 In 1937-1938 Fox, Buie and Clapp oarried out reconnaissance mapping in parts of the area between Kandabar and Parjuman on behalf of the Government of Afghaniatan. One progress report was made available to the writer in 1962, after work had almost Pinished on the Farah Rud, but the geologioal maps had apparently been lost.

1.9 In 1953-1954 His Excollenoy Dr. Sultan Ahmad Popol, and Dr. S.W. Tromp, traversed round Afghanistan and published an important paper on the stratigraphy and main struotural features of Afghanistan.

1.10 In $1955 \mathrm{H}$. Furrer was appointed Geologioal Adviser to the Government of Afghanistan under the U.N. Technical Assistance Program and undertook several investigations mainly in connection with hydro-geology. He summarised his conclusions in Report TAA/AFG/12, dated 12.12.1958. Dr. Furrer initiated the preparation of a geological reoonnaissance map on the scale 1:1,000,000. Additions to this map have since been made by Dr. J.P. Hunger, appointed by the U.N. Teohnical Assistanoe Board as Mineralogist and Ceologist to the Government. Dr. Hunger also undertook the geologioal mapping of the Tangi Saidan dam site which is described in Chapter of this present report.

1.11 Some geological sketch maps based on the Fairohild photography were prepared by members of the French Atomic Energy team. These showed the hilly area between Anardara and Shindand, with which the Speoial fund team was not concerned.

1.12 Systematic geological surveys have been undertaken in the northern part of the country by Soviet scientiats, but their results have not been made available.

1.13 The German Geologioal Mission in Afghanistan started work in 1958. Aside from detailed investigations of northern ooal areas, the greater part of its work has until recently been confined to the area north and east of Kandahar. No geologioal maps or reports prepared by this Mission have been seen.

\section{Seismic Information}

1.14 There is no seismographic station in Afghanistan. Numerous seismographs exist in Turkmeniya and Uzbekistan, north of the Amu Darya, and under UNESCO auspices a modern seismographio laboratory was installed in Quetta in 1954. All information about epicentral positions must therefore be obtained from countries whioh are contiguous with Afghanistan.

1.15 It is evident, therefore, that there was a great paucity of information regarding the geology of the areas in which the Special Fund team operated.

\section{References}

1.16 A complete list of references to geological literature up to 1954 is given in the publioation of Popol and Tromp cited below, ( $n .7)$. The following is an abridged list of some important literature.

1. Griesbach, C.L. 1881

Report on the Geology of the Section between the Bolan Pass in Baluchistan and the (jirishk Section in southern Afghanistan.

Mem. Geol. Surv. Ind., 18, Pt.1. 
Discusses the geology of the area east of that with which this present report is concerned.

2. Vredenburg, E.

3. Hayden, H.H.

4. Furon, R.

5. Tim de Jong

6. Furon, R.

7. Popol, S.A. and Tromp, S.W.
1901

1913

Mem. Geol. Surv. Ind., 31.

Geology of Northern Afghanistan

Mem. Geol. Surv. Ind., 39, Pt.1.

A classic memoir describing the region between Kabul and Ishpushta, but only of indirect concern to most of the Special Fund area.

1942 La géologie du plateau Iranien (Perse, Afghanistan, Béloutchistan)

Mem. Mus. Nat. d'Hist. Naturelle, Paris

of general interest.

1950 Kandahar-Herat Dam Inspection Report.

1951 J'Iran Perse et Afghanistan, Payot Paris

1954 The Stratigraphy and Main Structural Features of Afghanistan.

Koninkl. Nederl. Akad. van Wetenschappen, Amsterdam. B.57

A very useful summary of stratigraphical information resulting from traverses throughout Afghanistan.

8. Gutenberg, B. and Richter, C.F.

1954 Seismicity of the Earth.

Princeton University Press.

9. Furrer, K.

1956 Geology in Afghanistan

U.N. Technical Assistance Program TAA/AFG/12

Attemated geological information, but with a geological sketch map on the scale of $1: 5,000,000$.

10. International Engineering Co. Inc. San Francisco
1956 Report on Potential Dam Sites in Afghanistan. 
A slender report based on air and ground reoonnaissance desoribing 7 dam sites situated on 5 rivers in southern and south-eastern Afghanistan.

11. National Iranian Oil Company

1959

Explanatory Notes to the Geologioal Map of Iran. Tables, and a map on the soale $1: 2,500,000$.

A very valuable geologioal map with explanatory tables.

12. Gansser, A.

1959

Ausseralpine Ophilithprobleme

Eclog. Geol. Helv. 52, p.659.

13. Vvedenskaya, I.A. 1960

Problems of Seismic Zoning (in Russian)

Bull. Council of Seismology No.8.

Academy of Soienoes, U.S.S.R.

14. Desio, A.

1960
Ricognizioni Geologiche nell'Afghanistan

Boll. d. Soc. Geol. Italiana, Fasc.III.

Accessibility

1.17 Two major highways are at present under construction in Afghanistan. One highway, from Kushka to Kandahar, constructed with Soviet assistance, by-passes Farah, and joins the old Farah-Kandahar road west of Dilaram. The other highway from Kandahar to Kabul, built with help from U.S.A.I.D., runs parallel to the existing track. Until 1962 no part of these routes was available for traffic.

1.18 The principal route from Kabul to Herat is at present via Kandahar and Farah, and is $1162 \mathrm{Km}$. in length. The surface of this route is extremely rough except between Kandahar and Girishk. A speed of 40-60 Km.p.h. is possible. Gasoline consumption in the case of a Willys Jeep is about $7 \mathrm{Km} / \mathrm{litre}$.

1.19 The central route between Kabul and Herat through Hazarajat is $853 \mathrm{Km}$. in length. In general the surface is better than the more heavily used circuitous route via Kandahar, but there are many passes to cross up to 3200 metres in elevation, and numerous dangerous hairpin bends. The aggregate climb, excluding descents, on this central route is of the order of 9,500 metres. The highland part of the route is snow-bound from about mid-November to the end of May.

1.20 Motorable tracks exist off the main highways. Especially along the Farah Pud it was necessary to take the vehicles up wadi courses and over voloanic hills, with extensive use of 4-wheel drive and low-range gears. Gasoline oonsumption for the jeeps was of the order of $4 \mathrm{Km} / \mathrm{litre}$, and for the truoks, whioh were not able everywhere to follow the jeeps, $1.5 \mathrm{Km} / \mathrm{litre}$. 


\section{Aoknowledgments}

1.21 The writer wishes to record his thanks to his counterparts, at different times Mr. Ghulam Jan, Mr. Abdul Rauf and Mr. Ghulam Mohammed, for companionship in the field and much assistance, often under diffioult conditions.

1.22 His Exoellenoy Dr. Sultan Ahmad Popol, Deputy Minister, Ministry of Mines and Industries, and Mr. Salim, Direotor General of the Geological Survey, provided many faoilities.

1.23 From Mr. E.O. Dahle, and his successor Mr. S. Svindland, both of U.N.T.A.B., and Mr. D. Yakubi, of the Office of Aerial Photography and Mapping, there was unfailing and invaluable help over the supply and use of the air photographs, and examination of advance copies of the topographical sheets.

1.24 His Excellency Mr. Reza, formerly Co-Manager, and now Deputy Minister, Ministry of Aericulture, did much to facilitate the movements of the group.

1.25 Dr. Daniel Wirtz, and Dr. Mathias Kaever, of the German Geologioal Mission, kindly arranged for thin sections of rocks to be made and for the writer to examine them under a petrological microscope. 
CHAPTER 2 - FUNCTIONS OF A GEOLOGICAL SURVEY IN

ENG INEERING PROJECTS

\section{Qeneral Procedure}

2.1 In geological investigations of dam sites and reservoir basins it is necessary first to understand the background of regional geology and structure, before localising the studies to particular and limited areas. This is important in order to place the detailed picture within the regional framework, so that the structural disposition of bedded stratigraphic units, and the sequence of tectonic episodes, may be deciphered. For example, the delineation of active, and possibly seismic, faults may require a survey over a much wider area than that in whioh it is considered likely that a particular engineering project may be located.

2.2 Further, it is necessary to determine the location of raw materials for construction, such as cement limestones, and geological formations suitable for concrete acgregate, rock-fill and earth-fill dams.

2.3 Consequently a geological survey connected with dam sites, reservoir basins, hydro-electric schemes, and diversion tunnels cannot be confined solely to the immediate areas of such projects, but must extend over a wider region. It is therefore necessary to utilize geological maps on various scales, ranging from small soale generalized maps of the order of $1: 250,000$ to detailed geological maps of individual dam sites on scales such as $1: 2,000$.

2.4 In regard to the seismic stability of a region, it is required to obtain data from seismographic stations located in the country as well as in neighbouring terrains, in order to have a picture of the distribution of epicentres in relation to the project. The closer the network of indigenous seismographic stations, the more reliable become the data concerning the incidence of earthquakes in the region, and the desree of earthquake hazard.

2.5 The normal procedure therefore is to consult the geological maps of the country in order to obtain infornation regarding the regional framework, and to locate earthquake epicentres from seismic observatories.

2.6 As is evident from the previous section, however, such maps were not available in Afghanistan, and geological information was virtually absent. It was necessary to rely on photo-geological interpretation, and such traverses and detailed work in the field as it was possible to undertake.

2.7 At the very beginning of the survey two members of the team were able, on September 8 th 1960, to make a reconnaissance flight from Kandahar towards the Hari Rud near obeh and back over Ziarat $\left(33^{\circ} 17^{\prime} \mathrm{N}\right.$ : $\left.62^{\circ} 59^{\prime} \mathrm{E}\right)$. In a terrain with such a complex river pattern and geological structure as west-central Afghanistan, a first reconnaissance flight can do little more than indicate visually the nature of the country. It would in fact have been desirable to make several flights in order progressively to elucidate perplexities which have arisen from ground surveys, but under conditions obtaining during the investigations such recurrent reconnaissance flights were not possible.

2.8 It may be mentioned that while the writer was working on a Special Fund Projeot in Antalya Province of Turkey in 1963, a Turkish Airforce helicopter was twice put at his disposal, not only in order quickly to reach otherwise almost inaccessible gorges, 
whioh would have taken days to approach by land trails, but also to obtain an overhead perspective of geological conditions. Air photographs are often an invaluable means of determining geological structure, particularly in the oase of sedimentary formations which have been folded in a Jura manner, but in most parts of Afghanistan west of the Chaman fault (later to be desoribed) the photography may be very misleading unless areas are checked in detail on the ground, and periodically viewed from the air.

\section{Sequence of Investigations in Afghanistan}

2.9 Constant reference was made to the air photography whioh, in the areas covered by Fairohild, was on the following scales:-

$\begin{array}{lr}\text { Photo-Index unoontrolled Mosaion approximate soale: } & 1: 250,000 \text { to } 1: 300,000 \\ \text { 6" Photography } & 1: 50,000 \text { to } 1: 60,000 \\ \text { 12" Photography } & 1: 25,000 \text { to } 1: 30,000\end{array}$

Photo-creolotical interpretations were attempted of some of the areas with which the Project was concerned, but it was quickly realised how ambiguous such interpretations could be.

2.10 In some terrains a photo-geological interpretation, calibrated with a limited number of traverses on the ground, is sufficient to produce an accurate geological map. Such a map has recently been completed under the Colombo Plan of the area between the Makran coast and Baluchistan, as far north as Fort Sandeman, and a map must also be in course of preparation by the German Geological Mission from Wazikhwa northwards to Gardez. West-central Afghanistan is however a region with a less obvious structural Grain, where different geological informations often present the satne photographic appearance in black and white, and where a carapace of Neogene sediments frequently obscures the underlying formations. In such a refion there has to ke a much more extensive ground survey in order to discover the geological stmucture and succession.

2.11 In India, it was considered possible for one person to make a detailed geologic -al survey of a terrain of moderate complexity on the scale of 1 inch $=1 \mathrm{mile}$ $(1: 63,360)$ of $700 \mathrm{Km}^{2}$ during a season lasting 6 months. In western Afghanistan the concern is with an area of $70,000 \mathrm{~km}^{2}$, to cover which on Indian standards would require 100 man-seasons. Actually it is not the function of this particular special Fund Project to make a detailed geological survey of the region. But since no surveys are available, from which background information might have been obtained, and since some knowledge of the regional geology is essential in undertaking any work on encineering geology, the writer was compelled to make some compromise between what is ideal and what is feasible with the particular objectives of the project in view. It should be stressed, therefore, that the smaller-scale geological maps which accompany this report lack the accuracy of identification and structure which would more probably have ensued had it been possible to undertake systematic regional mappins.

2.12 There is little doubt that if it had been possible to undertake colour aerial photography, many of the ambiguities of identification would have been resolved. Colour photography would, however, have been prohibitively expensive. 
2.13 Dam sites and reservoir basins which had initially been selected from the air photographs were visited on the ground on a first reconnaissance, during which it was possible to eliminate obviously unsatisfactory locations. The more satisfactory sites and reservoirs were then selected for detailed topographical survey, on a scele of $1: 2,000$ or $1: 2,500$. The topographical survey of an area of 1 to $2.5 \mathrm{Km}^{2}$ having been completed, a geologioal survey was then made on the contoured foundation.

2.14 In addition, in some instances a photo-geological study, accompanied by ground traverses, was made of a wider area surrounding the dam site and into the reservoir basin. (Maps 6,8,10,14)

2.15 Laboratory facilities were not available under the Special Fund but, through the courtesy of the German Geological Mission, a limited number of thin sections of rooks were made for study under a petrological microscope, and Dr. Kaever of the Mission undertook determinations of certain fossils. 
CHAPTER 3 - GENERAL GEOLOGY

\section{Different Areas}

3.1 The writer was ooncerned with the following main areas:-

(1) W.S.W. of Kabul

(2) South of Ghazni: Katawaz

(3) Kash Rud to Farah Fud

(4) Farah Rud to Adraskand

(5) Hari Rud and Kawgan
Quartzites and slates, possibly Palaeozoic.

Neogene. Cretaceous-Eocene Limestone. Flysch, probably Mesozoio-Eocene.

Zone of Cretaceous Limestones strongly infolded with probably Mesozoic Flysch.

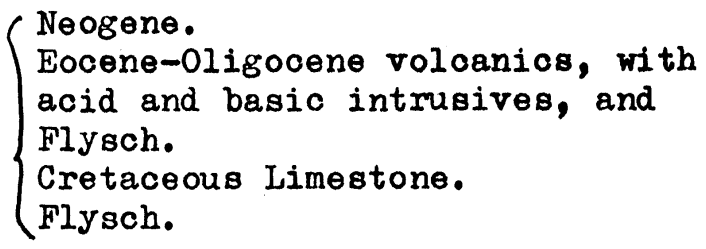

3.2 Over such an extensive area, not connected by regional geological mapping, it is impossible to provide any comprehensive stratigraphical sequenoe. From the point of view of engineering geology, excessive finesse in determining stratigraphical horizons is unnecessary. It should be stressed, however, that the determination of a correct historical succession of rocks is not just an academic luxury, divoroed from engineering applioations, because on the sequence depends the elucidation of structure, and the ages of earth movement. In this general discussion it is proposed only to touch upon certain aspects of the regional geology.

The Question of a Basement

3.3 No meso-grade metamorphic rocks have been found in the western part of Afghanistan except for the outcrops on both sides of the Hari Rud:- north and south of Herat; and between Salma, Obeh, Langar and Tangi Shah. These outorops expose injection gneiss, amphibolite, biotite gneiss, granulites, biotite sohist, phyllite, slate, quartzite. Their age is not known. It might be pre-Cambrian, but it oould be lower Palaeozoic. The rocks may be regarded as a true Basement which has been fraotured and re-juvenated by younger east-west faulting along the Hari Rud.

3.4 At Garmao, north of Tangi Azao, and around Tangi Shah, there are zones of slates and phyllites. At Tangi Shah there is a marked contrast between the slates and the more definite meso-grade metamorphic rooks, such as to suggest that the two groups are quite distinct. The slates are presumably Palaeozoic, but there is no fossil evidence in support. 
3.5 The granodioritic complex of Tasra Kai which underlies the Cretaceous Limestones, has a very "young" aspeot, and is provisionally regarded as Mesozoio. A oareful examination of the contact with the overlying Cretaceous limestones showed that the Cretaceous is entirely unmetamorphosed and includes detrital fragments of feldspars and quartz which have been derived from erosion of the underlying plutonio complex. It should be stressed, however, that if the complex was intruded during the Mesozoio, the country rook into whioh it was injected must have been entirely remored by erosion before deposition of the marine Cretaceous limestones. Consequently, on this assumption, there must have been not only the teotonic forces whioh accompanied intrusion of the magma into a cover of sediments, but those which caused uplift and erosion of the cover, all within the compass of the pre-Campanian (Senonian) Mesozoic.

3.6 No Basement has been observed over the whole of the Flysoh area south of latitude $34^{\circ}$. This condition obtains eastwards into Pakistan. The widespread Cretaceous-Eocene aoid and basic plutonio intrusions which extend from near Koh-iSultan to Mazari, Chagai, Dalbandin and to Farah, Kandahar, Hindubagh, and peak $11532 \mathrm{ft}$. ( $3515 \mathrm{~m}$. $60 \mathrm{Km}$. ESE of Urgun), in no way represent a Basement to the sedimentary succession. True Basement is not exposed until the outorops of the Kirana. Hills (31 ${ }^{\circ} 5^{\prime}$ : $\left.72^{\circ} 43^{\prime}\right)$, south of Sarghoda, are reached, whioh are part of the pre-Cambrian continental shield of peninsular Indo-Pakistan.

3.7 On the western side, in Iran, Metamorphic rocks, probably representing Basement, are present in the following locations, as indicated in the Geological Map of Iran:-

(1) On the west side of the Djaz Murian, $670 \mathrm{Km}$. south-west of Farah town. These outcrops form part of a NW-SE zone extending as far as Hamadan and Lake Rezayeh, and Turkish Khurdistan.

(2) In the core of a triangular area of uplift, $600 \mathrm{Km}$. west of Farah town.

(3) $70 \mathrm{Km}$. south-east of Mashhad, where the outcrops possibly represent an extension of the Herat Metamorphics. Towards the north-west the metamorphios may continue into the Elburz mountains.

3.8 No Basement is observed in the $1600 \mathrm{Km}$. between the central Iranian outorops of Metamorphios and the Kirana Hills near Sarghode.

\section{Ubiquitous Flysch}

3.9 One of the most striking geological characteristics of southern Afghanistan is the extent of Flysch. In this report the term Flysch is applied to rapid alternations of calcarous shale, calcareous sandstone and thin argillaceous limestone. The thiokness of individual beds usually varies from a few millimetres to $50 \mathrm{~cm}$, , but in some areas beds 20-metre in thickness occur. There is no clear lithological type. The sandstones are fine grained and contain silt and a caloium carbonate matrix. The shales are silty and almost invariably calcareous. Hence, all the beds fall well within a triangle, the corners of which are represented by quartz, calcium carbonate and clay material. The seas into which these beds were deposited must have been muddy and poor in animal life because fossils are rare in suoh a formation. Some of the Flysoh may have arisen by sub-marine slumping of sediments down the continental shelf and secondary accumulation in deep water at the foot. 
3.10 Associated with the younger Flysch are occasionally thick beds of conglomerate consisting mainly of pebbles, cobbles and boulders of Cretaceous limestone. This is an exceptional condition, but the writer has seen similar conglomerates within Flysoh in Antalya Province of Turkey.

3.11 According to the Pakistan Geological Survey, the extensive Flysoh in the area east of Chaman $\left(30^{\circ} 55^{\prime}, 66^{\circ} 27^{\prime}\right)$ has an age rangine from Oligocene to Miocene. Flysch occurs associated with post-Cretaceous volcanics, in the Farah Rud area, which are currently thought to be Eocene-0ligocene in age. The greater part of the Flysch in the Farah area is however certainly pre-Cretaceous, and it follows that in the area now covered by southern Afghanistan and Baluchistan, there has been a reourrence of palaeo-geographical oonditions which have given rise to successive produotion of the Flysch facies. It is possible that the Flysoh becomes progressively younger from south-oentral Afghanistan to Baluchistan.

3.12 In the region of the Kash Rud, north-east of Dilaram, there is a zone of Flysoh which is $30 \mathrm{Km}$. wide and has a persistent S.S.E. dip ranging from $30^{\circ}$ to $50^{\circ}$. The Flysch occurs in a group of high bare hills rising to over $3,000 \mathrm{~m}$. in elevation, into which the Kash Rud is deeply incised. It is evident that such a wide horizontal extent of outcrop must imply some degree of repetition by isoclinal folding or thrust-imbrication, but even so the probable true thickness must be several thousand metres.

3.13 Provisionally it is considered that in western Afghanistan there are two main periods of Flysch:-

(1) Pre-Cretaceous Flysch

(2) Post-Cretaceous Flysch
Well exposed between Siah $A b$ and Farah; $20 \mathrm{Km}$. from Jija Sarai on the road from Farah to Shindand; $25 \mathrm{Km}$. from Shindand on the road to Herat.

It is uncertain if the wide contimuous outcrop of Flysoh cut by the Kash kud is the same as the above or may be even Palaeozoic in age.

Well exposed up the Farah Rud from Urriah $\left(32^{\circ} 48^{\prime}\right.$ : $\left.62^{\circ} 43^{\prime}\right)$ to Robai Turkan $\left(32^{\circ} 48^{\prime}: 62^{\circ} 55^{\prime}\right)$ and northwards to west of the Farah-Malman confluence at 32053':63015'. This Flysch is associated with the Farah Volcanics and in some places is seen to overlie Cretaceous Limestone.

Metamorphism of Flysch

3.14 In the vicinity of Gul Kach (31056':69033') the Flysoh has developed a moderately high degree of epi-metamorphism, the more argillaceous units beins in form of a quasi-phyllite, with lenticular arcuate veins of quartz at the orests of the sharp folds. A similar condition exists in the Pishin Lora near coordinates $30^{\circ} 17^{\prime}$ ' $66^{\circ} 6^{\prime}$. Had the Gul Kach rooks been found in isolation, without the known context of fossiliferous formations, they could easily have been placed in the Palaeozoic or even pre-Cambrian. Yet the evidence suggests that this formation is 0ligoceneMiooene. 
3.15 The writer has had little opportunity to determine the varying degrees of metamorphian within the Cretaoeous limestones, though the literature indioates that these limestones are converted into marble where adjacent to granitio intrusions. The caloareous shales of the Flyseh are generally permeated with a fracture oleavage, some of the cleavage planes being occupled by calcite veins. The fracture oleavage becomes in some areas so intense that it approaches true oleavage in type, as is well seen on the north side of the Farah-Shindand road ahout $20 \mathrm{Km}$. from the Adraskand bridge at Jija Sarai $\left(33^{\circ} 01^{\prime}, 62^{\circ} 04^{\prime}\right)$. Here there is an antioline with a sharp south-east limb and a gentle north-west limb. The pronounoed fracture oleavage otrikes $280^{\circ}-100^{\circ}$, either vertical or with a steep S.S.W. dip.

3.16 A moderate to high degree of thermal metamorphism is found looally in the Flysoh, and in two localities can be attributed with certainty to intrusive plutonio masses:-

(a) South-west of Dehzak on hill $902 \mathrm{~m}$. near coordinates 32034' , 62029'. A granodiorite complex has caused the metamorphism of the calcareous shales, calcareous sandstones and limestones into banded hornfels, wollastonite rook and marble. The wollastonite orystals are up to $20 \mathrm{~mm}$. in length.

(b) Conical hill $17 \mathrm{Km}$. west of the Farah at coordinates 32022' \& 61056'. Here the banded Flysch has been converted into an intensely hard and tough hornfels, of which it is almost impossible to obtain hand specimens with a normal geologioal hammer. This hill is immediately adjacent to a gabbro complex.

3.17 A similar hornfels to that desoribed in paragraph 3.16 (b) above is found west of Robai Turkan, though no major intmusive mass is seen in the immediate vioinity.

3.18 That the fracture oleavage was earlier than the thermal metamorphism is demonotrated at the conical hill exposure mentioned above, where the oleavage is olearly visible, but is entirely sealed by re-crystallisation. It follows that the fracture cleavage arose from earth movements which were prior to the intrusion of the plutonio masses.

\section{Cretaoeous Limestone}

3.19 Cretaceous limestone is present throughout the area under consideration, and is characterised by the presence of Orbitolinas and Rudistes. The most fossiliferous localities which were seen are:

(1) Lashkar Ghar Gorge, and northwards along the lower 2 kilometres of the Ghor Rud.

(2) In the ravine from 3.2 to $4.7 \mathrm{Km}$. north of Jija Sarai bridge over the Adraskand river.

3.20 The limestone is not uniformly fossiliferous. At Assarasum and Tangi Shah no fossils were observed. At Tangi Azao there are sporadic large gastropods, and somewhat doubtful sections of Rudistes. At Tasra Kai the greater part of the limestone is unfossiliferous, but small broken fragments and mioro-foraminfera at the base, near the erosional contact with granodiorite, were identified by Dr. Kaever of the German Geological Mission as representative of the Upper Campanian. 
3.21 At Tangi Shah and Tangi Azao the limestone is massive and without visible bedding planes, forming a virtually monolithio mass. At Tasra Kal and Assarasum the limestone is more interbedded with oaloarous shales and some zones are highly oharged with ohert nodules. At Assarasum the limestone and shales have developed fraoture oleavage and slaty cleavage, and on the hillaide north of the dam oite it is diffioult from a distanoe to determine whioh divisional planes represent bedding and whioh are in fact oleavage.

3.22 The thiokness of the limestone is very variable. At Lashkar Ghar it is not less than 1,000 metres. At Tasra Kai between 500 and 1,000 m. At Tangi Shah the thiokness varies from 0 to about $140 \mathrm{~m}$., for the limestone has suffered erosion prior to the deposition of the Neogene.

Formations Below the Limestone

3.23 The formations underlying the Cretaceous Limestone are variable, and may be listed as follows:-

Tasra Kai

Assarasum

Tangi Azao

Tangi Shah

Adraskand south of Shind and

Farah Rud at Lashkar Ghar

Farah area
Granodiorite of presumed Mesozoic age.

Carbonaceous slates.

Phyllites, grey-greon slates with veins of caloite and quartz, oarbonaceous slates.

Green and purple shale, slate, phyllite, quartzitic phyllite, altered diabase. Vein quartz. This group of mainly argillaceous rocks is faulted against more high-grade metamorphics on the south-west side.

Flysch in a oleaved condition.

It was not possible to pass through the gorge to the outorops north of the limestone, but there is no doubt from the air photographs that the formation underlying the limestone is Flysch, with a swarm of intermediate or basic dykes.

Flysch, with a very strong unconformity which may be tectonic.

3.24 The idea was considered at first that the Flysch which underlies the Cretaceous limestone over wide areas around Farah may have been folded, and succumbed to oleavage and erosion, before deposition of the limestone itself. It was pointed out above, however, that at Assarasum the limestone and assooiated shales are also cleaved. No fossils were observed in this Assarasum limestone, and it is an assumption that the limestone is of Cretaceous age. But if the limestone is in fact Cretaceous, it follows that the dating of the cleavage must be either late Cretaceous or postCretaceous. An upper time limit can be assigned to the age of the cleavage, sinoe it developed before intrusion of the post-volcanic plutonic rooks (paragraph 3.18 ) and before intrusion of the Assarasum basalt which forms part of the volcanic series. The basalt, entirely uncleaved, cuts orthogonally across the cleavage planes of the carbonaceous slates on the right abutment. 
3.25 Consequently, it is possible that the regional oleavage, so well developed in some areas in the Flysch, and found also in the Assarasum limestone, may have developed subsequent to the deposition of the Cretaceous limestone, but before the extrusion of the Farah Voloanics and their associated plutonic rocks. The cleavage would thus have resulted from the same earth-movements that were responsible for the folding of the Limestone-Flysoh complex.

3.26 It is unwise to be dogmatic on this matter, but an alternative explanation may be that the strong unconformity between the Cretaceous Limestone and the underlying Flysoh is the consequence of different competence of the Limestone and Flysch to the tectonic stresses which affected both formations simultaneously. A locality where this explanation appears to be reasonable is on the WNE-ESE ridge at coordinates $322^{\circ} 8^{\prime}$; $620^{\circ} 5^{\prime}$, about $17 \mathrm{Km}$. from Farah gasoline station. The diapirio condition of a thick group of shales underlying massive limestone or sandstone in many anticlines is another example of a tectonic disoordance that is connected with a single perjod of folding rather than one which is due to two separate periods of folding acoompanied by an intervening erosion interval.

\section{Post-Cretaoeous Erosion}

3.27 At Tangi Shah, $85 \mathrm{Km}$. ESE of Herat, Cretaceous limestone whioh is about $140 \mathrm{~m}$. thick in the gorge totally disappears only $2 \mathrm{~km}$. to the north, near Safed Khara village. Around Lashkar Ghar, $180 \mathrm{Km}$. south-east of Herat, the Cretaoeous and Flysoh a.re both folded along NNW-SSE axes, and were subsequently partially eroded before eruption of the Farah Volaanics. The limestone and volcanics were then re-folded along a N.E.-S.W. axis, with much fracturing by thrust faults at the northern end of the syncline.

3.28 It is more difficult to decide on the relationships between Flysch, Limestone and Volcanios around Shindand. At a distance of $30 \mathrm{Km}$. south of Shindand there is the Cretaceous Ridge of Jija Sarai, with the normal sequence of Flysch-Cretaceous Limestone-Farah Voloanics. East of Shindand the sequence appears to be FlyschVolcanics-Neogene, without intervening Cretaceous Limestone. It is presumed that the Cretaceous limestone was totally removed by erosion, before eruption of the Shindand Volcanics, north of about latitude 33010', with the result that the Volcanios rest direotly upon Flysch.

3.29 Similarly, along the Slate zone south of the Hari Rud, $320 \mathrm{Km}$. east of Herat, Neogene rests direotly upon slates without intervening Cretaceous Limestone, although this limestone is present in force around Tasra Kai. 
CHAPTER 4 - TECTONICS

\section{Main Units}

4.1 The tectonio structure of southern Afghanistan is oomplex. An attempt has been made in map No. 4 to provide a superficial interpretation of the distribution of rooks types in the area west of longitude $65^{\circ}$ and between latitudes $32^{\circ}$ and $35^{\circ}$, but this has not been accompanied by any satisfactory understanding of the three-dimensional relationships of the rock units.

4.2 Aside from the zone of Metamorphic rocks along the Hari Rud, it was pointed out in paragraph 3.3 that no Basement is exposed over the whole area, and the exposed sub-stratum is everywhere Flysch. Along certain zones the Flysoh and Cretacoous limestone are present in a sharply interfolded manner, ridges of limestone standing perohed upon Flysoh or sometimes, as in Biboha Baran WNW of Farah, simulating an antiolinal structure within the Flysoh. This zone of interfolded Flysch and Cretaceous limestone has eeveral plutonic intrusions, and over wide areas volcanios may be present.

4.3 The Kash Rud area is exceptional, however, in having no broken oover of Cretaceous Limestone resting upon Flysoh. Here the Flysoh occurs over a wide zone with uniform SSE dip and great apparent thiokness. It is presumed that the Flysoh has been folded in concertina fashion upon a hidden Basement, but there is nothing to indicate the manner in which the inferred Basement has responded to the stresses which upended the Flysoh oover to such an extent.

4.4 The Flysch of southern Afghanistan, and the Rudistes Cretaceous limestone, probably resemble in structure the rocks of Tibet. Tibet and Afghanistan lie in equivalent positions beyond the geosynclinal rooks of the Himalaya and of the Waziristan-Baluchistan ranges, and are symmetrically disposed to the continental platform of peninsular Indo-Pakistan.

4.5 In the Farah-Shindand area, and around Kandahar, there are strong developments of voloanic rocks, of probable Eocene-0ligocene age, the Farah voloanios probably having a thickness of $2,500 \mathrm{~m}$. Intruded amongst these voloanics are acid to basio plutonio masses, of relatively small exposed dimensions :-

Visible Areas of Intrusive Rooks

\begin{tabular}{|c|c|c|}
\hline & & Area \\
\hline $\begin{array}{l}\text { Gabbro } \\
\text { Granodiorite } \\
\text { Granodiorite } \\
\text { Granite-granophyre }\end{array}$ & $\begin{array}{l}31^{\circ} 23^{\prime}: 61053^{\prime} \\
33^{\circ} 05^{\prime}: 610^{\circ}: 2^{\prime} \\
32^{\circ} 43^{\prime}: 63^{\circ} 00^{\prime} \\
32^{\circ} 42^{\prime}: 63^{\circ} 18^{\prime}\end{array}$ & $\begin{aligned} 38 & \mathrm{Km}^{2} \\
110 & \mathrm{Km}^{2} \\
50 & \mathrm{Km}^{2} \\
57 & \mathrm{Km}^{2}\end{aligned}$ \\
\hline
\end{tabular}

The acid intrusion of Maiwand, near Kandahar, is larger, having an area of approximately $250 \mathrm{~km}^{2}$. 
Bxtensive Fault System (Map 2)

4.6 Although the manner of folding at depth is not known, a very important feature of southern Afghanistan is the existence of major regional faults. An attempt has been made to demaroate the faults on map No. 2. The four faults of first importance are :-

Name of Fault Zone

Hari Rud

Farab Zone

Washir Zone

Chaman Zone
Direction

East-West

ENE-WSW

NE-SW

NNEE-SSW

\section{Length of Fault Zone}

$160 \mathrm{Km}$.

$150 \mathrm{Km}$. possibly 200

$200 \mathrm{Km}$.

$700 \mathrm{Km}$. with splinter

extensions of

$200 \mathrm{Km}$. towards

the north.

4.7 The existence of the Chamen Fault zone was knom long ago to the Geologioal Survey of India, but its full extent has only now become manifest from the air photography recently undertaken in Afghanistan and Baluchistan. The Chaman Fault is clearly developed from about $27^{\circ}$ latitude northwards almost to $32^{\circ} 45^{\prime}$, between Mukur and the Ab-i-Istada, north of which it becomes obsoured by superfioial deposits. The fault probably splays out, and one branch is almost certainly represented by the fault which follows the longitudinal depression in the mountains between Kabul and Ghazni that is oocupied by the motor road.

4.8 The Chaman fault is one of the major dislooations of the world. It probably has a strong component of horizontal shift, with the west orustal block moving south relative to the western one. Everywhere along it are pronounced tectonio discordanoes, the Flysch of the east block striking NE-SW into the NNE-SSW fault. At Chaman movement along the fault is thought to have been responsible for seismio shocks.

4.9 Similar angular discordances are evident in plan along the Farah and Washir faults. The Flysch of hill $1340 \mathrm{~m}$. (32026', 62028') is folded in a large arch which is partially truncated against the ENE-WSW fault.

4.10 A feature of the Farah and Washir faults is the existence of long narrow slivers of basic volcanic and perhaps intmasive rocks. The following may be indicated:-

\section{Positions of Voloanic Slivers along Fault Zone}

Related

Fault Zone

Coordinates

Farah Fault

Washir

$$
32^{\circ} 49^{\prime}: 63^{\circ} 31^{\prime}
$$$$
32^{\circ} 48^{\prime}: 63^{\circ} 35^{\prime}
$$

Length

Breadth

$15 \mathrm{Km}$.

$$
12
$$

$2.5 \mathrm{Km}$.

$2-3$

1.5

$32^{\circ} 08^{\prime}: 64^{\circ} 00^{\prime} \quad 16$

$32^{\circ} 52^{\prime}, 64^{\circ} 41^{\prime}$

60

$1 \cdot 5$
Direction

NNE-SSW) Offshoots from the NE-SW $\left\{\begin{array}{l}\text { main ENE-WSW Farah } \\ \text { Fault }\end{array}\right.$

NNE-SWW Parallel to the main fault

NNE-SSW Series of slivers with aggregate length 60 $\mathrm{Km}$. but sheared off and separated into chain of beads. Parallel to the main fault. 
It is probable that there is a causal connection between the faulting and the intrusion of basic magma along narrow zones parallel with or adjacent to the dislooations. The voloanio aotivity may have developed simultaneously with the formation of the block faulting and complex lateral crustal shifts between the blooke.

4.11 The Washir fault separates the wide zone of Kash Rud Flysoh, disoussed in paragraph 3.12, from the Helmand zone of limestones, voloanios and intrusives. The Farah fault in one area separates a zone of interfolded Flysch and limestone from the Farah voloanio and limestone zone. The abrupt change aoross the fault is well dieplayed at the headwaters of the Malman Rud, $30 \mathrm{Km}$. SSE of the Malman-Farah confluence, where volcanics on the north side are flanked by strongly folded Flysoh and limestone on the south side. Towards Farah the change is from the highly interfolded Flysch and limestone zone of Siah $\mathrm{Ab}$ on the south side to more extensive and massive outorops of limestone, suoh as that of the Siah Band Koh, together with Flysoh and voicanios, on the north side.

4.12 The Hari Rud fault system is of'interest in having a zone of considerable width, up to $500 \mathrm{~m}$. which is oocupied by a mélange of limestone blooks embedded within sheared purple conglomerate, purple and green shales and much fraotured slate approaching phyllite in sheen. Such rooks are seen north of the river around $34^{\circ} 22^{\prime}: 63^{\circ} 29^{\prime}$, and south of the river $135 \mathrm{Km}$. further east at $34^{\circ} 26^{\prime}: 64^{\circ} 57$. In the latter area, south-west of the Assarasum dam site, the drainage pattern shows a marked shift across the fault suggesting that the northern block has moved in relatively recent times about $750 \mathrm{~m}$. eastwards relative to the southern block.

4.13 In contrast to the signs of recently active faults south of the Hari fud near Assarasum, it does not appear that any of the faults in the Farah Rud region are still active. The cemented gravels, of probable Plio-Pleistocene age, which form such a contimuous spread west of Girishk, around Dilaram, and between Urriah, Daulatabad and Wadi Zamardan, are only very slightly tilted and have ouffered no folding or faulting (other than contemporaneous slump faults). These gravels abut directly and undisturbed against the highly folded and faulted Lower Tertiary and Cretaceous rocks, the movements in which must have been pre-Plio-Pleistocene. It would seem that this part of Afghanistan escaped the strong folding and overthrusting which involve even the Pleistocene Upper Siwalik rocks in northern India, Nepal and Pakistan.

4.14 Consequently, in the Farah Rud area it is assumed that the faults, whioh are seen so prominently in the Lower Tertiary volcanics and Flysch, have not been active since the time deposition of the Plio-Pleistocene gravels. Apart from the gentle warping of these gravels of very long wave length and low amplitude, the Farah area of Afghanistan has probably been immune from major teotonic disturbance since before the Pliocene.

\section{Convergence of Fault System}

4.15 It may be noted that the major faults converge towards the north-east in the area between Panjao and Charikar. The significance of this is not understood, but there is evidently a connection between the faulting and rotational movements whioh took place when the geosyncline was compressed between the continental platforms of Indo-Pakistan and Angara.

4.16 The faults in Iran, near the frontier with Afghanistan, are aligned north-south to NNW-SSE. Feults along a similar direction are suggested from a study of the Photo-Index mosaics of western Afghanistan, such as that which is present $70 \mathrm{Km}$. WNW of Farah town. The abrupt change in direction of both folds and faults between NNWSSE and ENE-WSW takes place in the depressions of Namakzur, Dasht-i-Barang and Seistan. 
4.17 South-western Afghanistan in fact forms part of a struotural triangle, with apex to the south, and it would appear from seismological evidenoe that the interior of this inverted triangle is relatively immune from major indigenous earthquake shooks. The Iranian, Mekran and Baluohistan fold systems form a perimeter to this triangle, which occurs as an enolave lacking any singular orogenio direotion. The area has figuratively been by-passed by the stresses whioh produoed the major folded zones between the northern and southern continental shields (paragraph 5.11).

\section{General Tectonio Framework}

4.18 Southern Afghanistan, south-eastern Iran and Baluohistan-Chagai belong to a palaeo-geographic unit which during the Mesozoic and Tertiary was quite distinot from that of Pakistan and India south of the Main Himalaya Range. In the writer's opinion it is suggested that the following are some of the characteristios of the structural unit in south Afghanistan:-

(a) Repetitions of Flysoh facies during the Mesozoic and Lower Tertiary

(b) Prevalence of Orbitolina and Rudistes Limestone in the Cretaceous

(o) Partition of the area into sub-units by major fault zones converging towards the north-east. Along some of these zones there was an outpouring of lavas, probably during the EoceneOligocene. The faults probably have a strong horizontal component of movement. One, at least, south of the Hari Rud near Assarasum, was active in recent times.

(d) Presence of mumerous plutonic masses, ranging from ultrabasic to acid in composition, and Upper Cretaceous to Lower Eocene in age. Several of these plutonic masses are mineralized:

Certain Mineralized Plutonic Rocks of late-Cretaceous to Eocene Age

Type of

Mineralization

Copper : Iron

Copper

Chromite

Iron

Wollastonite (contact metamorphism)

Zino

\begin{abstract}
Plutonic Rock

Granodiorite Ultrabasic Granodiorite Peridotite Granodiorite

Granodiorite
\end{abstract}

Gabbro Trootolite
Mountain Mass

Ras Koh $3009 \mathrm{~m}$.
Lar Koh
Hindubagh
Mai wand

Hill

Shuidar $3515 \mathrm{~m}$. $3279 \mathrm{~m}$.

$902 \mathrm{~m}$.

\section{Coordinates}

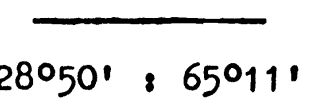

$300401: 670531$ $31^{\circ} 45^{\prime}: 65^{\circ} 23^{\prime}$ $32^{\circ} 24^{\prime}$ : 62029' $32036^{\prime}, 69^{\circ} 42^{\prime}$ $32^{\circ} 27^{\prime}$ : 69023'
Country

Chagais

Pakistan Iran Pakistan Afghanis$\tan$ Afghanis$\tan$

Pakistan with exten sions west wards into Afghani 8$\tan$ Iron Granodiorite
Damar Nissar $35^{\circ} 19^{\prime}, 71^{\circ} 41^{\prime}$

\section{Chitral}


CHAPTER 5 - SEISMICITY OF AFOHANISTAN

$$
\text { (Map 3) }
$$

\title{
Historioal Data
}

\subsection{Furon, in his book "I'Iran: Perse ot Afghanistan" (1951), lists oertain disastrous shocks that are stated to have devastated parts or much of Afghanistan during the last 460 years. These are emmerated below:-}

\author{
6.7.1505 Recorded by the Emperor Babur as affeoting India, \\ Afghanistan and Iran, with destruction of houses \\ and ramparts. \\ Jan. 1832 \\ Badakhshan was devastated. \\ 19.2 .1842 \\ 25 shocks during the day and 15 during the night, \\ "ravagent Kabul, Djellalabad et Peshawar". \\ 1874 \\ Almost the whole of Afghanistan was violently \\ affected, and houses were destroyed in an area \\ extending from Jebel es Seraj to Khorassan. \\ 30.3 .1934 \\ The province of Maimana was devastated.
}

It might be conoluded, therefore, that Afghanistan is an area which is subject to severe earthquakes, and that a large seismic factor should be included in the design of encineering structures. For reasons which are given below, however, it is suggested that the greater part of Afghanistan is probably not within the seismic zone, even though it must feel the effects of earthquakes in contiguous areas that are seismio.

Seismic Map

5.2 Accompanying this present report is reproduced a seismic map of parts of Asia (Map No. 3), which is based primarily on one published by Gutenberg and Richter entitled "The Seismicity of Asia". To this have been added more detailed information from Vvedenskaya regarding south central Soviet Asia. The epicentres of the majority of shocks indicated on the map are derived from seismographic evidence dating from the introduction of seismographs at the beginning of the century. Two shocks of the first magnitude which occurred within the last 200 years have also been included. The Ramree-Cheduba islands off the Arakan coast of Burma were elevated up to a maximurn of 6.7 metres as a consequence of a shook during April 1762. The Kutoh earthquake of 1819 initiated differential vertical movement along a fault within the Rann of Kutch, the upthrow side of which became known as the "Allah Band", and caused very extensive damage over westerm India and Sind. The effects of this earthquake were well studied by sound observers, so that the reports of destruction were not exaggerated and may be trusted. It is safe to regard both of 1762 and 1819 shooks as having had a magnitude of 8 or over on the Richter scale. Finally, the major transcurrent fault of northern Turkey has been taken from the "Notice Explicative de la Carte Tectonique de Turquie au $1: 2500000$ by Ketin (Ankara 1960). The other faults have been added by the writer. 
5.3 The largest conoentration of shallow shooks of the first magnitude is in southern Soviet Asia, along the Tien Shan between Do Shambe and the Issyk Kol. Other major shooks are conoentrated around the perimeter of the Tibetan plateau and its southern border of the Gangetio downwarp. Most of these large magnitude shocks are not associated with any known fault, but originate at depths of 10-30 $\mathrm{Km}$. below the earth's surface, some below strongly folded zones with sharp defleotions in the fold axes, and others where the continental orust shows a rapid increase in thickness at the edge of orogenic belt.

5.4 In northern Turkey, on the other hand, the great transcurrent fault, whioh is shown by Ketin to extend $1100 \mathrm{Km}$. from the Marmara Denizili to Erzinoan and almost to Van Gölü, has been the locus of several major shooks, that near Erzinoan being of first magnitude.

5.5 The Ramree-Cheduba shock off the Arakan coast of Burma is in comparable position to that of 1945 whioh had an epicentre in the Arabian Sea just off the Mekran coast. To these shooks may be added that of Kutch in 1819 whioh was oonneoted with the Kutch folds at the northern edge of the Indian peninsula.

\section{Seismic Zones}

5.6 An attempt has been made in this map to demarcate the seismic zones in which there is a concentration of epicentres. In certain parts of these broader zones the epicentres exhibit a particular orientation and closer spacing which justifies separate demarcation. Examples are in the two sub-zones of major shallow shocks, and one sub-zone of deep-focus shocks, which are present in south-central Soviet Asia and Badakhshan.

5.7 The delineation of seismic zones does not indicate that areas outside these zones are immune from shocks. For instance, although Delhi is located within a relatively stable area near the northern edge of peninsular India, it suffered some damage from the great Kangra earthquake of 1905, the epicentre of which was within the Himalayan foothills $400 \mathrm{Km}$. to the north. Again, the extremely severe shock of August 1950, which occurred near the tri-junction of India, China and Burma and had a macnitude of 8.6 or more, was strongly felt at a distance of $1100 \mathrm{Km}$. in Calcutta, where however only minor damage happened to old buildings. In general, it may be considered that a shook of the first magnitude will be felt over an area with a mean radius of $800 \mathrm{Km}$., while severe damage may be expected within a radius of $200 \mathrm{Km}$. from the epicentre.

5.8 Severe damage is not always confined to a sinele symmetrical area around the epicentre. In the case of the Bihar-Nepal earthquake of 1934 there were three distinct and quite separate zones of maximum damage:- in the Nepal valley; in the Gangetic plains north of the Ganga; and along the edge of peninsular India between Monghyr and Patna. This shock was felt over an area of $2,500,000 \mathrm{Km}^{2}$ (D.N. Wadia, J.A. Dunn, J.B. Auden, A.M.N. Ghosh: Mem. Geol. Surv. India, 73, 1939). The explanation for this peculiarity is that the northern and southern zones of high damage were connected with the juxtaposition of alluvium against hard rocks with very different elastic properties. More usually, however, it is normal to have a central area of severe destruction, surrounded by successively less damaged areas radially from the epicentre. 
5.9 Continental Basement areas of ancient metamorphic and intmaive rocks are usually stable and devoid of indigenous shooks. Most of peninsular India, Arabia and large parts of Africa may be regarded as free from serious seismio disturbanoes. On the other hand, areas of metamorphio rocks, which formerly belonged to a stable oontinental shield, but which later have beoome incorporated within orogenio zones, may coase to be stable. Two examples are oited. The lentioular mass of metamorphio rooks, which has a length of $350 \mathrm{Km}$, and is orientated NW-SE through Hamadan in Iran, is highly seismic. Indeed, the orientated area of partioular seismicity is approximately coincident with the metamorphio outcrop. Again, the Shillong plateau in India consists of Basement gneisses and intrusives of Archaean age which were oertainly part of peninsular India until the end of the Mesozoio. The plateau was later involved in uplift between two major downwarps, of Sylhet on the south side, with Tertiary sediments exceeding 10,000 metres in thickness, and upper Assam on the north side. The Shillong plateau formed the epioentral region of the great Assam earthquake of 1897, which is regarded as one of the greatest shocks of the last 100 years.

5.10 It has been indicated in Chapter 4 that Basement rooks are absent from western Afghanistan except for exposures along the Hari Rud valley, which have been involved in recent faulting. This is a condition which might lead to seismicity, but there is no evidence during the last 60 years of earthquakes being connected with these faulted metamorphics.

5.11 For the most part, western Afghanistan is characterised by a highly folded Flysch base (as distinct from true Basement) upon which Cretaceous limestone and volcanics have been superimposed. The region shows sharp folding limestones and minor thrust-faulting, such as at Lashkar Ghar. It lacks, however, the fartravelled nappe-de-charriage tectonics that are characteristic of the Alps and Himalaya along strongly orientated and relatively narrow orogenic chains. Instead, the region has the nature rather of a Zwischengebirge, with the splaying out of folds, and lateral shifts alone transcurrent faults which run across country along straight courses, with steep inclination. Within this region of Flysch and Cretaceous limestone are abundant volcanic rocks, together with basic and acid plutonic intrusions. Neither the association of rocks, nor the tectonics, is typical of a true orogenic zone (paragraph 4.17 ).

5.12 The seismic data provided by Gutenberg and Richter indicate that during the last 60 years, since the establishment of seismograph stations, there have been remarkably few shocks with epicentres that fall within Afghanistan proper. It is of interest to note that the major faults which traverse southern Afghanistan, and converge towards Panjao and Charikar, do not show any concentration of epicentres such as is characteristic of the San Andreas fault of California and the Erzinoan fault of northern Anatolia, Turkey. Even the long Chaman fault, which extends for $700 \mathrm{Km}$. and possibly $900 \mathrm{Km}$., lacks epicentres except where it approaches the fold deflections of the Quetta re-entrant. The shocks around Quetta are probably connected more with the fold deflections than with the Chaman fault, and the Baluohistan epicentres are orientated more in a NW-SE direction, extending across the Indus and being related poseibly to the conoealed Basement "High" of Jacobabad. The conclusion which may be reached is that the major faults of southern Afghanistan are not seismic.

$5.13^{\circ}$ In contrast to Afghanistan proper, there are concentrations of shocks in south-central Soviet Asia, in Badakhshan, around the Quetta re-entrant of Baluohistan, and some distance to the west in Iran. Maimana, in northern Afghanistan, is $400 \mathrm{Km}$. distant from the epicentre of the nearest first-magnitude earthquake olose to Do Shambe. Herat is $500 \mathrm{Km}$. away from the major shocks which have occurred near 
Ashkhabad. Kandahar is $200 \mathrm{Km}$. from the epicentre of the quetta earthquake of 1935, which caused great destruotion over a limited area, but was of second magnitude, and was not felt much beyond the confines of Baluchistan.

\section{Position of Afghanistan}

5.14 In paragraph 5.1 there is a list of five apparently very severe shooks, based on Furon, which are stated to have affected Afghanistan. In the map, however, it has tentatively been suggested that most of Afghanistan may lie outside the seismio zone, although it is in fact almost surrounded by seismic areas. There would thus appear to be a discrepancy.

5.15 As stated in paragraph 5.12, no shock of any magnitude has had an epicentre, within Afghanistan proper, during the last 60 years. Yet elsewhere, within the same period, umerous shocks have occurred with epicentres that display a strong concentration and a well-marked orientation. Thus even an interval of time of only 60 years has been suffioient to differentiate in a general manner zones with olusters of epicentres from areas which are virtually lacking in epicentres.

5.16 Admittedly, 60 years represent a very short period in comparison with geologioal time, and there can be no guarantes that in the future severe shocks will be strictly confined to the seismic zone which has been delineated on the basis of a short time interval. Since, however, there is a connection between seismicity and regional crustal structure, it need not be anticipated that any great departures will occur from the limits already indicated since 1905.

5.17 In regard to the historical evidence, the shock of 1505 recorded by the Emperor Babur is mentioned as having affected India, Afghanistan and Iran. If the boundaries of these countries had been the same as at present, this shock would cortainly have been of great magnitude, whether it had an epicentre near quetta or in southern Turkemeniya. In the 16 th century, however, the frontiers were much more fluid, and Babur did not capture Kandahar until 1507. Kandahar did not become the capital of a united Afghanistan until 1747, after havine changed hands between Iran and the Moghuls for over two centuries. The fact that Iran held both Kandahar and Herat at many times during this period would sugeest that to the contemporary mind Iran was probably considered to be much closer to India (modern India and Pakistan) than is so with the present politioal boundaries. Consequently, the area involved in the 1505 earthquake may not have been so large as is now implied by a modern Atlas.

5.18 The earthquake at Badakhshan in 1832 calls for no comment, because Badakhshan is on present seismological evidence a highly unstable area. The earthquake of 1842 may have originated in Badakhshan, which is $300 \mathrm{Km}$. north of Peshawar. The earthquake of 1874, which was felt between Jebel-es-Saraj and Khorassan, may have originated in southern Soviet Asia.

5.19 The earthquake of 30.3 .1934 , which is stated to have devastated Maimana Provinoe, lacks authenticity. A search through the catalogue of shallow, intermediate and deep-focus shocks prepared by Gutenberg and Richter (1954 edition of the "Seismicity of the Earth") has failed to reveal any important shock in or around Afghanistan during 1934. Only two class "a" (first magnitude) shocks occurred throughout the world in 1934, the nearest being that of 15.1.1934 in India, the epicentre of which is $2,200 \mathrm{Km}$. from Maimana. The nearest class "b" ahock, of 15.12.1934, originated $200 \mathrm{Km}$. north-west of Lhasa in Tibet. One minor olass "d" shock has been figured with an epicentre near Maimana, but it has not been possible to determine its date. Such a shock could certainly not have caused devastation over a wide area. 
5.20 It is a common experience that popular desoriptive acoounts of the damage incurred by earthquakes usually exaggerate the extent of the damage. It is necersary therefore to be cautious in accepting reports of severe damage unless oubstantiated by reliable eye-witnesses. The majority of houses in the general region of Afghanistan are likely to be oracked even from relatively amall local shocks. The oity of Kabul oertainly experiences numerous tremors, oufficient to cause oreaking of house structures, but within living memory no severe damage has been ocossioned.

5.21 On the other hand, it is possible to draw incorrect oonclusions about the absence of shocks based on the survival of apparently weak struotures. It was suggested in the writer's geological report on the Central Farah lud (FAO Report No.18147, para. 51, 1961) that the delioate Minars of the Massala at Herat would soarcely have survived if there had been any major earthquake in north-westerm Afghanistan. Mr. Tkachev, the Project, Manager, has pointed out, however, that the Minars of the Askhabad mosques have stood up very well to major shooks with opioentres very olose to the town, whereas many other sound structures oollapsed. The Massala minars of Herat are far from vertical, and look in a very precarious oondition, but it would appear that too much stress should not be given to their preservation throughout the centuries in regard to earthquake inoidence.

5.22 Reviewing the existing data, therefore, it is suggested that Afghanistan proper is an area in whioh large shooks do not originate, but that allowanoe must be given to the fringe effeots of major shocks which arise in surrounding countries, that are truly within the seismic zone. On present evidence, shocks of first magnitude are limited in the nelghbourhood of Afghanistan to southern Soviet Asia, and KutohMakran. Baluchistan is the loous of many shooks of secondary magnitude. There are olusters of smaller shooks in easterm Iran, but hitherto no large shook has ooourred in Iran since 1905 nearer than 1,000 Km. to Farah. Since the Special Fund Projeot is only conoerned in western Afghanistan with an area south of latitude $35^{\circ}$, it is suggested that only moderate allowanoes should be made against earthquakes in the design of structures. In parts of Northern India the reoommendation of the Geologioal survey of India was that a faotor of 12.5 percent $g$ should be adopted in design. In Afghanistan it is possible that 10 percent $g$ is a suffioient design factor.

5.23 In regard to Special Fund projeots within the Kabul River basin of northeastern Afghanistan, it may be noted that Kabul oity is $500 \mathrm{Km}$. distant from the nearest known zone of first magnitude shallow shocks, but is oloser to the zone of deep-foous shooks in Badakhshan. A slightly higher seismio faotor may be necessary in design of struotures in this area. 


\section{CHAPTER 6 - SILT CONTENT OF RIVERS}

6.1 The question of the silt content of the Afghan rivers is disoussed in rolumes

3 and 5 . Certain points may however be discussed in this present seotion. Vegetation is very ocarce in the Central Farah Rud, and is for the most part confined to about five species of xerophytic prickly shrub. Along the usually dry water courses leading from the mountain ridges, the Awal is the prinoipal bush, and may grow to a height of 3 metres, although 1 metre is more common. On the bare hill sides, for most of the year without any grass, except after the February-Maroh rains, there are scattered bushes most of which do not exceed half a metre in height, the most characteristic being the Koz-ba.

\subsection{The density of spacing of these bushes was measured on the terrace of the} Aliki Nai camp $\left(32^{\circ} 48^{\prime}, 63^{\circ} 03^{\prime}\right.$ : elevation $920 \mathrm{~m}$.). Over an area of $1,000 \mathrm{~m}^{2}$ it was found that there were 250 shrubs, making an average density of spacing of 1 shrub in every $4 \mathrm{~m}^{2}$. In spite of light rain having fallen on the terrace during the first week of March 1961, no blade of grass grew to relieve the barren stony ground. After extended rain, however, grass comes up and the bare hills assume a less arid aspect. This was very noticeable at Tangi Shah (34011':63006': elevation 1280 m.) in March 1962.

6.3 A slightly denser spacing of bushes was observed on the phyllite hillside at col 10552 feet $\left(34^{\circ} 20^{\prime}\right.$; 64\%58': elevation $3216 \mathrm{~m}$ ), of the order of 1 bush every $2 \mathrm{~m}^{2}$, but again no blade of grass was present when this ool was traversed in November 1961. It is indeed a mystery on what the goats manage to live in such a barren terrain, but the flocks wander the hillside long before rain has brought up the grass, and the shrubs at that time lack any succulence.

6.4 Muoh of the higher reaches of the Hari Rud and Farah Rud is covered by a carapace of Neogene silts and conglomerates. To such an extent is this cover developed that it is almost impossible from a study of the air photographs, and very diffioult even on the ground, to outline the complex boundary that exists between the Neogene and the underlying older rocks. An attempt has been made, in Map No. 14 of the Tasra Kai area of the Hari Rud, to make such a demarcation, but the true boundary is certainly more intricate than that which is shown on the map.

6.5 The signifioance of this cover of Neogene rocks is that it is very susceptible to rosion. In so far as the area above $2,000 \mathrm{~m}$. is under snow for several months in the year, erosion during the winter is absent. But run-off from the melting of the snows is responsible for the existence of abundant runnels and small side tributaries, and it is olear that the easily eroded silts must add greatly to the silt content of the rivers.

6.6 The very large area of Flysch exposed in the Farah fud catchment north of latitude $33^{\circ} 07^{\prime}$, and of the Ghor Rud north of $33^{\circ} 06^{\prime}$, exposes abundant calcareous shales which erode with ease. During the dry season the Farah Rud at Lashkar Ghar is faintly turbid with an almost colloidal suspension, which leaves a very fine ind slippery soum on the rooks. This fine transported load quickly changes, however, to a chocolate coloured opaque fluid after storms, and a glassful of such water may leave a precipitate of $5 \mathrm{~mm}$. after two or three days of rain. 
6.7 Data provided by the Helmand Authority for the Arghandab demonstrate that during the year November 1955 to October 1956 the silt load (presumably suspended silt) was $8,422,062$ tons for a discharge of $2,065,000,000 \mathrm{~m}^{3}$, equivalent to an anmual average of $4.07 \mathrm{Kg} / \mathrm{m}^{3}$. During April 1956, the silt load was 5,543,000 tons for a discharge of $640,000,000 \mathrm{~m} 3$, equivalent to a load of $8.65 \mathrm{Kg} / \mathrm{m} 3$. The catohment area at the point of measurement is $15,150 \mathrm{~km}^{2}$, implying a removal of suspended silt during 1955-1956 of 555 tons per square kilometre. Assuming a density of settled silt of 1.3 , it follows that the volume of silt removed during 1955-56 was $422 \mathrm{~m}^{3}$ per square kilometre. The specific discharge during 1955-56 was 4.32 litres/ $\mathrm{Km}^{2} / \mathrm{s}$. Furon (1951, p.194) cites a figure of 8 grammes of silt per litre for the Helmand when in flood $\left(8 \mathrm{Kg} / \mathrm{m}^{3}\right)$, which agrees olosely with the data which were subsequently obtained for the Arghandab that are cited above.

6.8 For a comparison, reference may bo made to a paper entitled "Sediment in Rivera of the Indus Basin" published by Nazir Ahmad and three other authors (Pakistan Journal of Soience, Vol.9, No.6, p.250, 1957). The following data refer to the Kabul river at Warsak, which is $34 \mathrm{Km}$. downstream from the frontier with Afghanistan. The catohment area of the Kabul river at Warsak is $67,000 \mathrm{Km}^{2}$. The original data for discharge and sediment content were given in acre-feet, but these figures have been re-calculated to metric units, in columns 2 and 4 , and further data have been derived from them in the other columns. The Pakistan engineers have assumed a density of $87 \mathrm{lbs} / \mathrm{cu}$. ft. equivalent to $1.4 \mathrm{~g} / \mathrm{cm}^{3}$. For Afghanistan, following Meade, a figure of $1.3 \mathrm{~g} / \mathrm{cm}^{3}$ has been adopted.

\section{Sedimentation in Kabul River at Warsak}

\begin{tabular}{|c|c|c|c|c|c|c|}
\hline Year & $\begin{array}{l}\text { Discharge of } \\
\text { Kabul River } \\
\mathrm{m}^{3}\end{array}$ & $\begin{array}{l}\text { Specific } \\
\text { Discharge } \\
\text { litres } / \mathrm{Km}^{2} / \mathrm{s}\end{array}$ & $\begin{array}{l}\text { Volume } \\
\text { of } \\
\text { sediment } \\
\text { axsuming } \\
\text { density } \\
1.4 \mathrm{~g} / \mathrm{cm}^{3} \\
\end{array}$ & $\begin{array}{l}\text { Weight of } \\
\text { sediment } \\
\text { derived } \\
\text { from volume } \\
\text { in col. } 4 \text { - } \\
\text { tons } \\
\end{array}$ & $\begin{array}{l}\text { Overall } \\
\text { oontent } \\
\text { for the } \\
\text { anmual } \\
\text { discharge } \\
\mathrm{Kg} / \mathrm{m} 3 \\
\end{array}$ & $\begin{array}{l}\text { Unit Rate } \\
\text { of silting } \\
\mathrm{m} / \mathrm{Km}^{2} / \\
\text { annum }\end{array}$ \\
\hline $\begin{array}{l}95 \\
95\end{array}$ & $\begin{array}{l}16,670,000,000 \\
18,790,000,000\end{array}$ & $\begin{array}{l}7.9 \\
8.9\end{array}$ & $\begin{array}{l}6,530,000 \\
1,420,000\end{array}$ & $\begin{array}{l}37,000,000 \\
58,000,000\end{array}$ & $\begin{array}{l}2.2 \\
3.1\end{array}$ & $\begin{array}{l}396 \\
618\end{array}$ \\
\hline
\end{tabular}

6.9 It is seen that the unit rate of silting for the two years under observation varied from 396 to $618 \mathrm{~m} 3 / \mathrm{Km}^{2} /$ annum, which may be compared with the Arghandab rate for one year of $422 \mathrm{~m}$. On the other hand, the overall average silt content of the Kabul river per cubic metre of the annual flow was less than that of the Arghandab. This fact must be considered in the light of the higher specific discharge of the Kabul river, which is about twice that of the Arghandab, and the different nature of the catohments, since the Panjshir and Kunar tributaries of the Kabul river are largely glacier-fed.

6.10 It may be of interest to give some indication of the silt content of Himalayan rivers which were determined by the Central Water and Power Commission of the Govermment of India. A.N. Khosla had previously indicated from a study of rivers located mainly in the western states of the U.S.A. that the average rate of silting into reservoirs may be taken as 0.75 acre-feet of silt per square mile of catchment per annum. This is equivalent to 357 cubic metres of silt per square kilometre per anmum. It had been regarded as a matter of doubt if this rate would be applioable to Himalayan rivers, and when measurements were carried out on the Beas and Kosi rivers it was found that the suspended silt discharge was some 5 to 7 times that indicated from a study of American catchments. For the Kosi it appeared probable that the silt discharge would be 2,500 cubic metres per square kilometre per annum. 
6.11 The Himalayan rivers have a different geological background, and a different olimate, to those in Afghanistan. They flow for part of their course through easily eroded up-ended Siwalik sediments, which are absent in this condition in the Farah area. Moreover, $90 \%$ of the anmual rainfall of 1,500 to $2,000 \mathrm{~mm}$. falls within 5 months of the year, implying a concentration of erosive aotivity. Nevertheless, south-western Afghanistan presents extensive areas of easily eroded Flysoh and Neogene sediments, and the rainfall, weak though it be, is confined to a few months in the year. While it would be unsound to draw rigid conclusions from comparisons made between terrains that are not strictly equivalent, the fact remains that the rivers of south-western Afghanistan are remarkably silty when in flood, and it may be advigable to assume a rate of silting during years of high precipitation, of $1,000 \mathrm{~m} / \mathrm{Km}^{2} /$ annum. For a period of several years, includine years of low precipitation, an average rate of silting might tentatively be regarded as within the range of $400-700 \mathrm{~m} 3 / \mathrm{km}^{2} /$ annum. 
CHAPTER I - KARSTIC CONDITIONS

7.1 Extensive terraces of Travertine, or calcarous tufa, exist in the Kajao tributary of the Logar river upstream of the Kajao dam site, reaching a width of $1.4 \mathrm{Km}$. These form part of an earlier erosion cycle, for the terraces lie upon slates, and the river has now cut down through the travertine and into 20-80 metres of the underlying slates. The thickness of the tufa and assooiates marls is about 50-70 m.

7.2 Travertine is also exposed up the Rud-i-Turkman tributary of the Ghorband, and small travertine mounds exist at the Tangi Saidan dam site in the Bala Maidan river close to Kabul. This tufa nay possibly be connected with spring discharge along a fault plane.

7.3 The most interesting development of Travertine is at the lowest of the Band-iAmir lakes (approximately 34050': 67009') at an elevation of about $2700 \mathrm{~m}$. This lake is blocked by a self-produced semicircular dam of Travertine with a maximum height of about $8 \mathrm{~m}$. There has clearly been much solution of limestone or calcarous marl within the catchment, in order that so much tufa could be deposited from the lake water.

7.4 These occurrences are $a l l$ in northern and eastern Afghanistan and they point to some degree of solution and to the probable existence of karstic limestones.

7.5 Conditions appear to be different in western Afghanistan, with which this report is mainly concerned. The Cretaceous limestone is relatively ubiquitous, and in places reaches a thickness of 1000 metres. So far as can be determined, however, these limestones are not karstio. Streams do not disappear into Düdens, and the air photographs do not indicate the characteristic pitted or indented surface to the limestone outcrops such as are common, for example, in Antalya Province of Southern Turkey.

7.6 The principal reason for the absence of obvious karstic characteristics is probably the low rainfall. It is not thought that the precipitation in the western highlands of Hazarajat exceeds $300 \mathrm{~mm}$., while in the lower foothills and plains near Farah it is probably of the order of $100 \mathrm{~mm}$. Karstic conditions are not normally developed unless the rainfall exceeds $600 \mathrm{~mm}$.

7.7 A contributary factor to the apparent lack of karstic solution effects in areas such as the Lashkar Ghar and Tasra Kai dam sites is the presence of less permeable beds of calcarous shale between the more massive beds of limestone. These shales act as barriers to migration of groundwater through the joints and bedding planes of the purer and more persistently jointed limestone.

7.8 The significance of this tentative conclusion in regard to western Afghanistan is that there is less fear of reservoir losses in a terrain that lacks karstic characteristics, and does not appear in the limestone zones to have an underground system of water migration that is entirely separate from, and with a different orientation to, the surface drainage pattern. 
7.9 In regard to north-eastern Afghanistan, the frequent ocourrence of travertine suggests karstic or quasi-karstic conditions, and this would indicate a higher rainfall. Nuch of the travertine is found above an elevation of 2,000 metres, in a region where the precipitation may lie between 600 and $800 \mathrm{~mm}$.

7.10 In spite of the abundance of travertine along the Kajao river, no fear need arise regarding karstic conditions within the proposed reservoir. The travertine of the Kajao valley belongs to an earlier erosion cycle, and was derived from. solution of limestones which are not actually within the reservoir basin. The reservoir itself would be located mainly within slates and quartzites, together with travertine terraces that are based and flanked by slates and quartzites. The reservoir should, therefore, be watertight. 


\section{PART II - PROJEC'PS ON THE FARAH RUD}

CONTENTS

Chapter 8. PREVIOUS INVESTIGATIONS OF DAM SITES

ON THE FARAH RUD

$1-14$

Tim de Jong Report 1950

International Engineoring, Co. Inc. 1956

$1-8$

$9-14$

9. GENHRAL GEOLOGY: CHITRRAL FARAH RUD

$1-13$

Broad Relationships

$1-12$

Faults and Shatter Zones

10. DAM SITE AND RESERVOIR TOPOGRAPHY

$1-11$

Bakhshabad-Gashakbar Tangi and heservoir

Aliki Nai Tangi and Reservoir

Lashkar Ghar Gorge and Reservoir

$3-6$

$7-8$

$9-11$

11. GEOLOGY OF BAKHSHABAD DAM SITE

$1-19$

General

$1-4$

Nature of AEglomerate

Shatter Zones

Alternative Alignments

Exploration Required

$5-7$

$8-10$

$11-14$

Raw Materials for Construction

15

$16-19$

12. GEOLOGY OF ALIKI NAI DAF SITE

$1-18$

General

Lithology

Alternative Alignments

Excavation Grade in River Bed

Spill way Channel

$1-4$

$5-7$

$8-12$

Raw Materials for Construction

14

$15-18$

13. LASHKAR GHAR DAM SITE

$1-42$

Date of Fxamination

Acoess

General Geology

Detailed Geology of the Gorge

$1-3$

$4-5$

$6-15$

Location of Dam

$16-19$

Raw Materials for Construction

$20-26$

Exploration

$27-34$

$35-37$

Conclusions

$38-42$ 
14. CONDITIONS OF WATERTIGHTNESS IN THE THREE RESERVOIR BASINS

$$
\begin{array}{r}
1-13 \\
1-6 \\
7-10 \\
11-13
\end{array}
$$

Bakhshabad

Aliki Nai

Lashkar Ghar

15. TABULATHD COMPARISON BETWEEN BASHSHABAD, ALIKI NAI AND LASHKAR GHAR

16. LOWER FARAH RUD

$M a p a$

Map 5 Geological Map of the Bakshabad Dam Site

6 Geological Map of the Bakshabad Area

7 deologioal Map of the Aliki Nai Dam Site

8 deological Map of the Aliki Nai Area

9 Geologioal Map of the Lashkar Ghar Dam Site

10 Geologioal Map of the Lashkar Ghar Area 
PART II - PROJECTS ON THE FARAH RUD

CHAPTER 8 - PREVIOUS INVESTIGATICNS OF DAM SITES ON THE FARAH RUD

8.1 Two reports were made available in regard to geologioal investigations of dam sites on the Farah Rud:

(a) Kandahar-Herat Dam Inspection Report by Tim de Jong, General Engineer - 25.3.1950.

(b) Report on potential Dam Sites in Afghanistan by the International Engineering Company, San Francisco. December 1956.

Tim de Jong Report 1950

8.2 Tim de Jong investigated the Aliki Nai and Lashkar Ghar dam sites on the Farah Rud, together with the Kaoghan dam site $\left(34^{\circ} 12^{\prime}\right.$; 63002') on the main tributary of the Hari Rud (Tagao Haft Qala or Tagao Ishlan), and the northern Karmuck tributary of the Hari Rud.

8.3 Tim de Jong's descriptions are somewhat lacking in topographical details, but the first site which he examined on the Farah Rud was that which he termed the Peechee site. From his account it would appear that the Peechee site should be the same as that now mapped by Messrs. Meade and Pallister as the Gashakbar site (approx. coordinates 32053': 62049'). Tin de Jong did not see any storage capacity upstream of this site, and in 1950 there were no aerial photographs, so that ho was unable to appreciate, without actually traversing up the gorge, that the Farah Rud valley opened out into a wide basin only $3 \mathrm{~km}$. upstream of the Tangi. He accordingly rejected the Peechee (Gashakbar) site as providing no storage potentiality, and went on upstream by a circuitous route away from the river.

\section{Aliki Nai Dam Site}

8.4 Reaching the Farah Rud from Aliki Nai village in the south, Tim de Jong solected two possible dam sites, the first choice of which is located about 100 metres upstream of the confluence of the Aliki Nai river with the Farah Rud. An alternative site was considered by him to lie 1,000 feet downstream of the first one, but this is more likely to be the site about 500 metres downstream just below the right-angle bend in the Farah Rud.

8.5 Tim de Jong described the right abutment as consisting of a sandstone bluff, while the left abutment was regarded as a sloping layered sandstone formation. A natural spillway was found on the right bank about 1,000 feet away from the river in the form of a saddle 160 feet (say $50 \mathrm{~m}$ ) above river level. This was also thought to be located in sandstone.

8.6. It should be remarked that Tim de Jong was mistaken in identifying the rocks as sandstone. The rocks at his dam site are voloanio, and the so-called sandstone is in reality a banded rhyolite grading into a banded rhyolitio ash. His two dam sites are both upstream of the Aliki Nai Tangi which the Special Fund has studied. 
8.7 The following are the tentative figures given by Tim de Jong for a dam provisionally estimated to be 150 feet (say 46 metres) in height:

\author{
Width of river \\ Length of reservoir \\ Storage oapacity \\ Stream flow on 17.1 .50 . \\ Estimated flood
}

180 metres
$14.4 \mathrm{Kmm}$.
$740,000,000 \mathrm{~m}^{3}$
$9.5 \mathrm{~m} 3 /$ seo.
$460 \mathrm{~m}^{3} / \mathrm{sec}$.

He estimated that material was probably present for the construotion of an earthfill dam.

Lashkar Ghar (Gah)

8.8 Tim de Jong finally went upstream to visit the Lashkar Ghar (Gah) dam site, which is situated at the downstream end of a very tight gorge near ooordinates 33002': 63020'. The abutments of this site were shown by him to consist of solid limestone, capable of taking thrust aotion. River width was estimated at 18 metres. For a dam of 300 feet height ( $92 \mathrm{~m}$ ) ) the orest length from his description would be only about $70 \mathrm{~m}$. He considered that this site would be suitable for the oonstruo$t$ ion of a concrete-arch or masonry-aroh dam.

International Enginoering Company Ino., San Francisco. 1956

8.9 In January 1956 the International Engineering Company of San Franoisco issued a Report on Potential Dam Sites in Afghanistan, based partly on ground reconnaissanoe and partly on air reconnaissance. The following were the sites considered:-

$\begin{array}{ll}\text { Farah Rud } & \text { Upper Dam Site } \\ & \text { Lower Dam Site } \\ \text { Khash Rud } & \text { One Site } \\ \text { Arghandab River } & \text { Middle Dam Site } \\ & \text { Upper Dam Site } \\ \text { Arghastan River } & \text { Upper Dam Site } \\ \text { Pishin Lora } & \text { One Site }\end{array}$

8.10 As far as the Farah Rud is concerned, their work appeared to have been confined to air reconnaissance, although the photograph taken of the Upper Farah Rud site might have been taken from the ground.

Upper Farah Rud (Lashkar Ghar)

8.11 There is no doubt that the Upper dam site of the United States Company is that at Lashkar Ghar, the oblique photograph No.3 of their report clearly oovering the aame part of the river as is inoluded within Fairohild air photographs 9/14309 and 9-A/14256.

8.12 The site was stated to be in a limestone gorge and was considered as capable of taking a $150 \mathrm{~m}$. dam, which might have a crest length at that height of $700 \mathrm{~m}$. and be of a thin-aroh design. Suitable fine and coarse aggregate was thought to be looated on an old meander about $5 \mathrm{Km}$. upstream of the dam site, a suggestion whioh is not borne out by subsequent study. 
Lower Farah Rud Dam Site

8.13 This site was definitely only seen from the air, and the oblique photographs 4 and 5 of the company report cover respectively Fairchild air photographs $7 / 14715$ 14716 and $6-D / 14685$.

8.14 The rocks were thought to be thin-bedded shales, limestone and sandstones, and a rock-fill or earth-fill dam of $70 \mathrm{~m}$. height was considered to be feasible. It should be stated at once that the geological formations which were thought from air reconnaissance in 1956 to be a bedded sedinentary series, have been found by ground inspeotion during the present investigation to be voloanic lava flows and acid intrusive sills. It is in fact a matter of some difficulty in this particular terrain of Afehanistan to be sure of the lithology solely from a study of air photographs. 
CHAPTER 2 - GENERAL GEOLOGY: FARAH RUD

Broad Relationships

\section{Sequence}

9.1 The apparent sequence of formations is given in the adjacent table. Cretaceous limestones crop out extensively to the north in major ridges orientated roughly east-west, from Lashkar Ghar westwards to Zarmardan and Ab Khurma Sarai. The limestone mountains which are displayed south of the Farah Rud, from south of Robai Turkan to east of Urriah, are also probably Cretaceous, and form the southern flank to the volcanic basin.

9.2 The basin of Farah Rud volcanics and Flysch sediments is itself corrugated into subsidiary anticlines and synclines, with a Flysch facies coming up exposed in the anticlinal cores just east of the Gashakbar Tangi and around Robai Turkan. The Bakhshabad dam site lies on the eastern limb of the Bakhshabad synoline, which is a secondary synoline within the main basin.

9.3 An excellent route for studying the local relationships is by ascending the wadi which joins the left bank of the Farah Rud about $3 \mathrm{Km}$. upstream of the centre of Urriah village. On marching from Urriah the inferred Plio-Pleistocene cemented gravels are found resting on the Farah Volcanics, which dip westwards. After entering the wadi the volcanics are seen to be underlain by the thick series of red limestone conglomerates. These in turn are followed by chocolate and brown coloured contorted Flysch shales, calc sandstones and thin limestones.

9.4 The contact with the limestones on the south side of the Farah Rud has not been observed, but disturbed contacts are seen west of the Malman confluence with the Farah Rud. Here the Cretaceous limestone of the beautiful Malman peak arch over toward the east until they become vertical or even overturned. Above them lies a limestone conglomerate with pebbles of fossiliferous Cretaceous Limestone, and then a mixed voloanic-flysch series, all dipping eastwards, on the west side of the Malman synoline.

9.5 Another locality where the relationships are well exposed is along the path between Aliki Nai and Robai Turkan, about $4.5 \mathrm{Km}$. W.S.W. of the Aliki Nai/Farah Rud confluence. Here the Flysch at the bottom of the local succession is slightly metamorphosed to a micro-crystalline hornfels. Above the Flysch come several beds of $20 \mathrm{~m}$. thickness of a coarse limestone conglomerate, many of the cobbles being of fossiliferous oretaceous limestone, ranging in age from Aptian to Albian (determination M. Kaever). Above the limestone conglomerates are found the Farah Volcanics dipping westwards on the east limb of the Robai Turkan syncline.

9.6 The metamorphism of the Flysch is due to the major plutonic mass of Aliki Nai which lies just to the east of the exposure. Cutting the pluton, the sediments and the volcanics, are muerous dykes, ranging in composition from trachyte to andesite.

9.7 The boulders in the limestone conglomerate reach size of $30 \mathrm{~cm}$, and must have been of relatively local origin. The conglomerates were evidently deposited by rivers flowing with considerable gradients over up-ended Cretaceous limestones. 
Apparent Geological Succession in the Area of the Central Farah Rud and Adraskand

\begin{tabular}{|c|c|c|c|c|}
\hline & & $\begin{array}{l}\text { Approx. } \\
\text { Thickness } \\
\text { Metres }\end{array}$ & & Representative Looalities \\
\hline Reoent & 7 & & River Alluvium. & Farah Rud downstream of Dehzak. \\
\hline $\begin{array}{l}\text { ? Plio- } \\
\text { Pleistocene }\end{array}$ & 6 & $30+$ & $\begin{array}{l}\text { Cemented gravels } \\
\text { \& oonglomerates }\end{array}$ & $\begin{array}{l}\text { Urriah; Daulatabad; Wadi; } \\
\text { Zarmardan Farah Rud } 40 \mathrm{Km} \text {. dom- } \\
\text { stream of Farah Bridge. }\end{array}$ \\
\hline Neogene & 5 & $? 1,000$ & $\begin{array}{l}\text { Clays and sand- } \\
\text { stones of Siwalik } \\
\text { type (? volcanics) }\end{array}$ & $\begin{array}{l}\text { On road } 38 \mathrm{Km} \text {. from Shindand } \\
\text { towards Herat. }\end{array}$ \\
\hline & & & & $\begin{array}{l}\text { The Red Beds seen from the dir } \\
\text { in the centre of the Ziarat } \\
\text { triangular basin }\left(33^{\circ} 20^{\prime}, 62^{\circ} 58^{\prime}\right) \\
\text { are possibly Neogene. They } \\
\text { overlie Shindand volcanics. }\end{array}$ \\
\hline $\begin{array}{l}\text { ? Oligocene } \\
\text { ? Eoceno }\end{array}$ & 4 & $\begin{array}{l}\text { up to } \\
2,500\end{array}$ & $\begin{array}{l}\text { Farah Rud volcanics } \\
\text { and inter-trappean } \\
\text { sediments }\end{array}$ & $\begin{array}{l}\text { Farah Rud from Bakhshabad to } \\
\text { Aliki Nai, Malman and Lashkar } \\
\text { Ghar. }\end{array}$ \\
\hline ? Eocene & 3 & 500 & $\begin{array}{l}\text { Limestone Conslom- } \\
\text { erate and Flysch }\end{array}$ & $\begin{array}{l}3.5 \mathrm{Km} \text {. ENE of Urriahs } 4.25 \mathrm{Km} \text {. } \\
\text { WNW of Aliki Nai/Farah Rud } \\
\text { confluences South of Robai Turkan. }\end{array}$ \\
\hline $\begin{array}{l}\text { U. Cretaceous } \\
\text { Aptian- } \\
\text { Cenoman }\end{array}$ & 2 & $\begin{array}{l}\text { up to } \\
1,000\end{array}$ & $\begin{array}{l}\text { Rudistes Limestone } \\
\text { Orbitoline Limestone }\end{array}$ & $\begin{array}{l}3.4 \mathrm{Km} \text {. north of Adraskand Bridge } \\
\text { Jija Sarai; Lashkar Ghar, Lower } \\
\text { Ghor Rud. }\end{array}$ \\
\hline $\begin{array}{l}\text { ? Jura } \\
\text { Trias }\end{array}$ & 1 & $\begin{array}{l}\text { several } \\
1,000\end{array}$ & Flysch & $\begin{array}{l}\text { Farah-Shindand road } 20 \mathrm{Km} \text {. from } \\
\text { Jija Sarai Shindand-Herat road } \\
25 \mathrm{Km} \text {. from Shindand. }\end{array}$ \\
\hline & & & Intrusive Rooks & \\
\hline ? Oligocene & III & & $\begin{array}{l}\text { Basalt, Andesite \& } \\
\text { Porphyry Dykes }\end{array}$ & $\begin{array}{l}\text { As swarms throughout the area of } \\
\text { the Farah and Shindand Volcanics } \\
\text { and in Adjacent Flysch }\end{array}$ \\
\hline $\begin{array}{l}\text { Probably late } \\
\text { Cretaceous to } \\
\text { lower Eocene }\end{array}$ & $\begin{array}{l}I I b \\
I I a\end{array}$ & & $\begin{array}{l}\text { Granodiorite Complex } \\
\text { Gabbro Complex }\end{array}$ & $\begin{array}{l}\text { Aliki Nai ridge }\left(32^{\circ} 43^{\prime}, 63^{\circ} \mathrm{O} 0^{\prime}\right) \\
\text { Char-i-Tir Koh Massif } 17 \mathrm{Km} \text {. west } \\
\text { of Farah Town }\end{array}$ \\
\hline & Ib & & $\begin{array}{l}\text { Acid Injeotion } \\
\text { Complex }\end{array}$ & $\begin{array}{l}\text { b-ii as white-weathering sills } \\
\text { and dykes especially between } \\
\text { Bakhshabad and Aliki Nai } \\
\text { b-i as a major elliptical hollow } \\
\text { around } 32^{\circ} 42^{\prime} \text { '63'18', overlain } \\
\text { on the perimeter by basio lavas } \\
\text { and possibly layered gabbros only } \\
\text { seen from the air. }\end{array}$ \\
\hline
\end{tabular}


The limestone conglomerates are not seen everywhere between the Flysch and the Volcanics, and their sporadic outcrops probably mark the courses of the ancient rivers which flowed over the newly folded and elevated Cretaceous limestones, during movements which were initiated at the end of the Mesozoic.

9.8 In the part of the Farah Rud upon which there may be construction of dams and storage reservoirs, the essential sequence would thus appear to be:

Top

Plio-Pleistocene Cemented Gravels

Farah Rud Volcanics with interbedded sediments

Local Limestone Conglomerate

Flysch, in some places of considerable thickness

Local Limestone conglomerate (east flank, Malman Peak)

Bottom

Cretaceous Limestone of the Malman Peak

9.9 The sequence is of importanoe to the question of the probable water tightness of the basin. If the Cretaceous Limestones had oropped out at the surface along the course of the Farah Rud, they might have been an avenue of considerable leakage to any reservoir which would be formed above them. On the oontrary, aside from the outcrops of Cretaceous limestone along the rim of the basin, no limestones are seen within the basin, and the effective floor of the basin, where exposed in anticlines, is composed of Flysch. The Flysch is characteristically a calcareous shale formation, with less common beds of sandy limestone, calcereous sandstone, and impure limestone. Essentially, therefore, it is impervious, and forms a non-permeable insulating bottom between the lavas and the foundation of Cretaceous Limestone.

Irregular distribution of Volcanics

9.10 The voloanics present a difficult problem to map. Unlike in areas of widespread plateau basalts, where individual lava flows behave over considerable distances with a geometric consistenoy of thickness and extent which is characteristic of an undisturbed sedimentary succession, the lava flows of the Farah Rud are more variable in composition and thickness, and more localized in distribution. In addition they are strongly folded and faulted, so that a structural discontinuity is superimposed on irregularities in original extent and thickness.

9.11 It is not indeed always possible to differentiate between the irregularities inherent in extrusion of acid to intermediate lavas, and emission of pyroclastics, from localized vents, and those which were due to fault displacements which must have occurred during volcanio eruption.

9.12 To add to these difficulties, extensive zones of acid intrusion, and acid intrusive complex, are present, particularly between Bakhshabad and Aliki Nai. The more uncontaminated intrusions stand out clearly in the air photographs as white masses. In the field they reflect sunlight with a dazzling intensity. They are, however, related zones of acid injection in which the lavas are caught up as blocks of varying size, and the whole becomes a complex of intrusive and extrusive 
material. This complex is not easy to unravel in cases where acid magma has been injected into rhyolites, for the intrusive rook itself may have a rhyolitio texture. Suoh cases are common both at the Bakhshabad and Aliki Nai dam sites.

Faults and Shatter Zones

9.13 The manner of displacement of orustal blocks in this region may be classified as followg:

(a) First Order regional fault zones, such as the Farah and Wakhir teotonic lines, mentioned in Chapter 4, with an extent of $100 \mathrm{Km}$. or more. These are regional lines of disturbance frequently marked by large-scale structural discordance between adjacent crustal blooks, and probably characterised by a strong horizontal component of movement. They may be compared with the San Andreas Rift and Hayward's fault of California. The faults in the Farah region are regarded as static and not seismic, but it is possible that one fault parallel to the Hari Rud south of Qal-eh-Ahangaran may still be active, and hence possibly seismic.

(b) Second Order faults, extending for several kilometres, such as those well displayed around Aliki Nai, and along the volcanic slivers in the upper Malman Rud. These faults split the lavas into strongly discordant blocks and probably also represent movements with a horizontal component.

(o) Thrust faults. A thrust fault is well developed along the left bank of the Farah Rud at the Aliki Nai dam site. There is a system of north-south thrust faults near Lashkar Ghar. The western fault is steep, but the fault which brings Cretaceous limestone to rest across the younger volcanics has an angle of about $45^{\circ}$ from the horizontal.

(d) Shatter Zones. The shatter zones are elongated fractures characterised by shattering and disorientation of the rocks over a width of several metres. There is frequently no net displacement, and the disturbance to the formations may have been due to oscillatory movements, or to shear under oonditions which did not permit of relief by actual shift. Three such shatter zones have been recognized in the Bakhshabad area, and one at Aliki Nai. Two of the Bakhshabad shatter zones have minor quantities of acid injection and carbonate mineralization, and head towards an acid injection complex. The fracturing may have been partially connected with strain as magma was implaced.

(e) Minor displacements along intrusive dykes. The dykes were intruded at a time of crustal tension, and there has evidently in some instances been a subsequent gravity settlement parallel to the original tension fissure. 
CHAPTER 10 - DAM SITES AND RESERVOIR TOPOGRAPHY

10.1 Topographioally there are three reaches of the central Farah Rud which are narrow enough to take a dam of not excessive dimensions. Upstream of each of these narrows the valley opens out to provide suitable storage reservoirs:-

(a) Bakhshabad-Gashakbar Tangi:

(b) Aliki Nai Tangi:

(o) Lashkar Ghar Gorge.

10.2 The Bakhshabad Tangi was visited, presumably near its middle, by Tim de Jong in 1950, but no storage possibilities were visible to him at the particular point of the river which he reached. It was photographed from the air by the International Engineering Corporation. The upper end of the Aliki Nai Tangi was considered by Tim de Jong as offering the best prospect for a dam, but the International Engineering Corporation made no mention of this gorge in their report.

\section{Bakhshabad-Gashakbar Tangi and Reserroir}

10.3 The Bakhshabad-Gashakbar Tangi has a total length of about $6 \mathrm{Km}$. measured along the river, but only the lower $2.8 \mathrm{Km}$. are of interest for the construction of a dam, and possible dam sites are confined to the upper and lower ends of this lower portion. Only the lowest site, at Bakhshabad, has been geologically mapped in detail, using the 1:2,000 topographical base prepared by G. Meade and provided piecemeal to the writer.

10.4 The minimum width of the gorge at the lower end at low water level is $60 \mathrm{~m}$. and at a height of $60 \mathrm{~m}$. above L.W.L. is $240 \mathrm{~m}$. The minimum width at Gashakbar is $53 \mathrm{~m}$. between two ribs of lava, but the average width is about $80 \mathrm{~m}$. Width at $+60 \mathrm{~m}$. is $330 \mathrm{~m}$. High flood level as indioated by sand-filled embayments is $9 \mathrm{~m}$. above L.W.I. The gradient between the Bakhshabad and Cashakbar sites is $3 \mathrm{~m} / \mathrm{km}$., or 1.333.

10.5 The Farah Rud valley opens out about $3.2 \mathrm{Km}$. upstream of Gashakbar and has been studied by the Topographical Section of the Special Fund. The reservoir upstream of Bakhshabad, with a dam at $+60 \mathrm{~m}$. elevation relative to L.W.L., would have a maximum width of about $10 \mathrm{~km}$. at two oppositely aligned tributaries. Storage increases rapidly at elevations exceeding $40 \mathrm{~m}$. above Bakhshabad L.W.I., but unfortunately the flat terraces of cemented gravels, which are so pronounced on the north side of the reservoir, are just too high to augment reservoir volume with a dam $60 \mathrm{~m}$. in elevation.

10.6 The reservoir volume for a dam of $60 \mathrm{~m}$. elevation above L.W.L. at Bakhshabad would be of the order of $573,000,000$ cubic metreg, whereas a dam at Gashakbar up to the same level would impound about $540,000,000 \mathrm{~m}^{3}$.

\section{Aliki Nai Tangi and Reservoir}

10.7 The Aliki Nai Tangi is about $4 \mathrm{Km}$. in length, but only about $0.5 \mathrm{Km}$. is of interest in the location of a dam. River width is $160 \mathrm{~m}$. Including, however, the low rook terrace or berm on the right bank, the width is more nearly $200 \mathrm{~m}$. between the steep abutment sides. At an elevation of $60 \mathrm{~m}$. above L.W.L. the width is about 
half a kilometre. Mr. Purtaph Singh has indicated from the maximum elevation of the sand pockets on the abutments that high flood level averages 8.5 metres above low-water regime. The river gradient at low water is $2.7 \mathrm{~m}$. in $1,700 \mathrm{~m}$., whioh is $1.6 \mathrm{~m} / \mathrm{km}$ or 18630 . The volume of a concrete dam in this tangi would be almost twice as large as that for a dam looated in the Bakhshabad tangi.

10.8 The Farah Rud valley opens out considerably above the confluenoe with the Aliki Nai stream, but no complete reservoir surveys have been made of this area, and a direct comparison with the Bakhshabad reservoir is not possible. Tim de Jong made a rough estimate, without any survey, of 600,000 acre-feet, or $740,000,000$ oubic metres with a dam $150 \mathrm{ft}$. or $46 \mathrm{~m}$. in height. A subsequent study of advance copies of the 1:50,000 Afghanistan maps by the Topographical Group has indicated that the reservoir volume at Aliki Naj for a dam 60 metres in height above present bed level would be $368,000,000 \mathrm{~m}^{3}$. The eye estimate, therefore, exaggerated the volume, which is probably to be explained by the deceptive appearance of the terraces which, though of gentle slope, may involve a considerable diminution in volume if they rise above a particular height of dam. The river gradient for $6.8 \mathrm{Km}$. upstream of the tangi was found to be $2.06 \mathrm{~m} / \mathrm{km}$.

\section{Lashkar Ghar Gorge and Reservoir}

10.9 The Lashkar Ghar gorge was not visited until October 1962, when advance copies of the 1:50,000 toposraphical maps of the area were available. The only really suitable section of the gorge for the construction of a dam is at the lower end just upstream of where the Farah Rud debouches into the structural basin of rolling voloanio hills. No suitable site exists upstream of this lower section, until on the Farah Rud about $1 \mathrm{Km}$. upstream of the confluence with the Ghor Rud. This second site was not visited, but the air photographs indicate that the gorge is out through limestones, which dip downstream towards the east.

10.10 The year 1962 was one of exceptionally low rainfall, and it is due to the fact that the river discharge at Lashkar Ghar was probably not greater than $6 \mathrm{~m} 3 / \mathrm{sec}-$ ond during october that it was possible to ford the river so easily. In a more normal year, with a winter disoharge of up to $10 \mathrm{~m} / \mathrm{second}$, there are seotions of the gorge which would require a rubber boat. The gradient within the gorge is $2.25 \mathrm{~m} / \mathrm{km}$.

10.11 A dam at Lashkar Ghar would create a reservoir which would flood up both the Farah Rud and the Ghor Rud. The reservoir would be narrow for a distance of $15 \mathrm{Km}$. on the Farah Rud, and $10 \mathrm{Km}$. on the Ghor Rud, upstream from the Lashkar Ghar dam site, but above these points the valleys open out into good storage basins. A dam of more than $30 \mathrm{~m}$. height would be required at Lashkar Ghar in order to develop any storage in the Farah Rud basin upstream of the gorge. 
CEAPTER 11 - BAKHSHABAD DAM SITE

(Maps 5, 6)

11.1 The geologioal formations present at the Bakhshabad dam site consist of the following units:-

\section{Thickness}

9 River sands and gravels

? $10 \mathrm{~m}$.

8 Gravels of the right bank ravine ? $20 \mathrm{~m}$.

7 Prophyry and basic dykes

6 Acid Intrusive Complex

5 Andesite Group

4 Amygdaloidal Group

3 Trachyte Group

2 Agglomerate Group

1 Infra-Agglomerate Group

not determined

100-110 m.

80-90 m.

$300 \mathrm{~m}$. in N.E. of area

uncertain

The identification of the lavas depends on a limited number of rook seotions whioh were examined in the Deutsche Geologische Mission.

11.2 Disposition: of these units, numbers 3,4 and 5 are relatively consistent in their disposition and thickness, while units 1 and 2 are much more variable. The width of the agglomerate outcrop is $340 \mathrm{~m}$. where exposed near survey station 64, and the following subdivisions can there be reoognized:

2-o non-bedded agglomerate by station 71.

2-b bedded agglomerate and ashes

2-a non-bedded agglomerate of station 64.

Towards the south-west the width of outcrop of the agglomerate group decreaces to 80 metres, and the subdivisions are not recognised. This variation is probably due to original irregularities in lava eruption and dropping of pyroclastios. On the other hand, the variations in the lowest mapped group of lavas and pyroclastics is probably due to a discordant intrusive contaot with the acid complex on the south-east side.

11.3 The voloanios atrike N.N.E.-S.S.W., which is obliquely across the gorge. The dip varies in magnitude from $45^{\circ}$ to $60^{\circ}$ from horizontal in a W.N.W. direction, whioh is obliquely downstream. The right bank is virtually a scarp slope, while the left bank at the provisional dam axis is a partial dip slope. This relationship changes to one that is almost orthogonal where the river bends towards the west.

11.4 There is a strong upstream E.S.E. - dipping joint system, particularly in units 2 and 3, which affords a deceptive impression of an actual upstream-dip in the voloanios, an impression whioh is much evident on making the descent to river level from survey station 69. In addition, there is a pronounced vertical eastwest jointing in the Trachyte unit 3 on the right bank, which is with little doubt causally related to the concealed western extension of the river shatter $z$ one. 


\section{Composite Nature of Agglomerate}

11.5 If the dam is located in the narrowest section of the gorge, it would be based entirely on the Agglomerate group No.2. This might on first consideration be regarded as an unfavourable foundation. The writer has however experienced difficulty in making a satisfactory petrological diagnosis of this so-called Agglomerate group, for the formation where it is well exposed and water-polished on the right bank is massive and gives a preliminary impression of being a lava flow. Yet closer inspection shows that the rock is manifestly heterogeneous, consisting of lava blocks of various sizes embedded in a fine-grained matrix. Some of the blocks are up to $30 \mathrm{~cm}$. in length but the more usual size is $10-15 \mathrm{~cm}$.

11.6 In thin section under the microscope there is the same heterogeneity, and fragments of different types of rhyolite, trachyte and andesite, from 1 to $2 \mathrm{~mm}$. in lensth, are found scattered in a fine matrix. But the matrix does not appear to be a normal ash, suggesting more nearly the nature of a fine-grained lava. It is also possible, however, that metasomatism has so altered an original ash as to give it the verisimilitude of a fine-grained lava. Two alternatives present themselves. First, that the material may be partly a true lava flow, into which were dropped at the time of extrusion ashes and lava blocks, which would suggest a designation asglomeratic lava. Second, that the material was formerly a true pyroclastic agglomerate, with ashes and lava blocks dropped from an eruptive and explosive source, and that a subsequent metasomatism has altered the ashy matrix so as to destroy its original porosity and give it a deceptive appearance of being a lava. In this case the material would have to be designated a metasomatised agglomerate. From a practical engineering point of view the precise petrological nomenclature is not of much importance, but it has nevertheless been necessary to discuss the nature of the rock because of the suspicion with which agglomerates are normally held as a foundation to a major dam.

11.7 The bulk of the Agglomeratic Lava, or Metasomatised Agglomerate, as exposed near river level in the gorge, would appear to have a low matrix porosity and permeability. Such permeability as may exist is likely to be along the strongly developed joint planes, which dip steeply in an E.S.E. direction. On the other hand, the bedded subdivision of the group 2, and the coarse agglomerates of station 64, may possess more permeability. On account of talus and poor exposures, it is uncertain how far the bedded agglomerates and ashes of subdivision 2-b extend to the upstream dam alignment, but an attenuated exposure of this subgroup may be expected around contour level $300 \mathrm{~m}$. , as soon as the right abutment has been stripped of its loose debris.

Shatter Zones

11.8 Structurally the most striking feature of the Bakhshabad dam site is the existence of three shatter zones; one on the north-west bank which is accompanied by faulting, one along the gorge entering the gorge from the left bank just upstream of the provisional dam axis, and the third on the left bank. The only shatter zone which concerns the dam foundations is that running along the river. On the left bank it is conspicuous as a gully running east-west. The gully is 12 metres wide at river level, but expands to 17 metres at a height of 10 metres above the river. A major jointing with $45^{\circ}$ dip in a south direction is developed within the shatter zone, but there is also extensive irregular jointing and the existence of a moderate amount of siderite mineralisation along some of the more sheared portions. 
11.9 The shatter zone is lost under river gravels along the axis of the gorge, but in the writer's opinion it must extend westwards and be responsible for the old course of the Farah Rud which is now marked by a gravel-filled ravine. As stated in paragraph 11.4, the marked vertical east-west sheet jointing of the Trachyte band on the right bank is likely to be related to the concealed shatter zone.

11.10 The gravel-filled ravine is of interest because, in addition to the normal current-bedded sands, and water-worn pebbles and cobbles in the gravels, there are embedded also large angular blocks of local lavas up to one metre in length within the old river deposits. It is evident that these blocks fell into the former ravine of the Farah Rud from one or both of its banks, and that the banks must have been steep enough to allow for gravity fall. The narrowness of the gravel-filled ravine, the presence of the lava blocks which fell into the old channel, and the east-west orientation of the channel in direct extrapolation with the pronounced gully on the left bank, all indicate that the river was then following a considerable length of the shatter zone, for a distance which is not less than 600 metres. It may therefore be concluded that this feature has important lateral extension, and will be present in the foundations of the dam with the likely three alternative axes.

\section{Alternative Alignments}

11.11 There are three alternative alignments, which can be emmerated as follows:

\begin{tabular}{ll}
\multicolumn{2}{c}{ Before Wxcavation } \\
\hline Width at & Width at \\
L.W.L. $280 \mathrm{~m}$. $\quad 340 \mathrm{~m}$. \\
\hline
\end{tabular}

Upstream

alignment N.N.W.S.S.E. $\quad 70 \mathrm{~m}$. $240 \mathrm{~m}$.

Central Alignment

N.N.E.-S.S.W.

62

340

Downstream

Alignment

N.N.E. -S.S.W.
112
Agglomerate Group 2. Irregular dip slope on left bank. Right bank possibly with ashes of 2-b near 300 contour

Geological Formation

Massive type of agglomerate on both banks. Axis along strike

Trachyte, but upstream heel of dam might encounter thin acid intrusive sill on excavation in bed of river. Axis of dam along strike.

11.12 All three alignments would meet the river shatter zone in the bed of the river. The upstream alignment would encounter this zone on the south-east side, while the other two would meet it on the north side. With the present topographical configuration there is no doubt that the upstream alignment would have the smallest volume, but it is probable that much of the present surface on the left bank would have to be stripped away, and that excavation grade may be considerably deeper than the surface as now exposed. A rough estimate suggests that the volume of a concrete or masonry gravity dam at the upstream alignment up to the $340 \mathrm{~m}$. contour might lie between 325,000 and 350,000 cubic metres. 
11.13 The two downstream alignments would definitely involve larger quantities of concrete, but they present advantages in the relation of the dam axis to the structural disposition of the geological formations. The geologically most predictable alignment would be the lowest, which would be located on the Trachyte unit No.3, which has lithological consistency and homogeneity. Moreover, the axis of the dam would coincide with the strike of the Trachyte. The dip of the Trachyte at river level is $60^{\circ}$ towards the W.N.W. The dam axis at river level (elevation $279.2 \mathrm{~m}$.) would be aligned approximately 20 metres downstream of the footwall contact of the Trachyte with the underlying Acid Injection Zone. With a downstream dip of $60^{\circ}$ this footwall contact would be at an elevation of $244.5 \mathrm{~m}$., or $35 \mathrm{~m}$., below the upstream face of the dam at river level. Allowing for an upstream batter of 9 metres at river level, and an average depth of excavation, except for the river shatter zone, of 15 metres, that is to elevation $264 \mathrm{~m}$., it would only be the batter heal which would at $264 \mathrm{~m}$. extend beyond the Trachyte into the underlying Acid Injection zone. If a total base width of the dam at foundation, with orest level $340 \mathrm{~m}$. and excavation level $264 \mathrm{~m}$., of $70 \mathrm{~m}$. (inoluding batter) is assumed, the downstream toe would be located in the Trachyte and virtually the whole foundation, except for a small portion of the upstream batter, would have a monolithic Trachyte base. This alignment would certainly involve a dam with greater volume than that at the upstream end of the gorge, but it might present fewer geological problems.

11.14 The two downstream alignments would have relatively narrow ridges as abutments, so that there would be a disposition towards loss of water at the downstream free exposed surfaces of these ridges, which would be virtually coincident with the downstream faces of the dams. In this respect, the upstream alignment has the advantage, because the two abutments are to a much less extent eroded into ridges and gullies orientated along the strike.

\section{Exploration Required}

11.15 It is not possible to go beyond these very provisional statements about the choice of alignment. The final selection must depend on extensive exploration of the abutments, and on a comparative study of the river shatter zone under the three alignments. This exploration will involve the following principal operations:-

(a) The sinking of a shaft on the right bank near station 24 to a depth between 20 and 30 metres, and the driving of an under-river tunnel about $100 \mathrm{~m}$. in length to explore the shatter zone below the bed of the river.

(b) Exploration of the river bed and abutments by means of diamond drill holes, both vertical and at an angle from the vertical, and a detailed study of the cores.

(c) The driving of several tunnels on the abutments in order to obtain a visual impression of the joints and shear zones, and the general soundness of the rock.

(d) The undertaking of water-percolation tests through many of the diamond drill holes, in order to study the water losses in the different geological formations, and to decide on the extent of the grouting programme. 
Raw Materials for Construotion

11.16 The indigenous volcanic rooks would not in general be suitable for the preparation of crushed aggregate on account of the strong jointing and splintery fragments which would be produced. The Bakhshabad Tangi is, however, favourably placed in regard to river gravels and to terrace gravels, both of which are present downstream of the Tangi.

11.17 The river gravels immediately downstream of the Tangi are about 200 metres in width, and are present contimuously throughout the course of the river to Farah. In addition, there are high-level terrace gravels, the nearest of which fill the ravine that forms the old course of the Farah Rud that was discussed in paragraphs above. This gravel-filled ravine is only 50-60 m. wide at the upstream end, but expands to more than $200 \mathrm{~m}$. on the west side. The largest terrace, from which an unlimited source of supply may be assumed, muns for $7.5 \mathrm{Km}$. in a N.E.-S.W. direction, from near the right bank $2.5 \mathrm{Km}$. downstream of the Bakhshabad gorge. These gravels rest on an irregular surface of volcanics, and have an average thickness of perhaps 20 metres.

11.18 The bulk of the constituents of these gravels are:

Volcanio rooks: Plutonic rocks: Limestones:

Sand stones : Shales: aoid, intermediate and basio granodiorites from the Cretaceous outcrops in mountains flanking the Farah Rud in the Malman-Lashkar Ghar area Flysch calcareous fine-grained sandstones from the Flysch, and Inter-trappeans.

The majority of these terrace gravels have a strong calcareous cement between the sandy matrix. To work them will probably involve blasting. Volcanic rocks rich in opaline silica, which might initiate an alkali reaction with most normal cements, have not been noticed, and it is not thought likely that much danger need be anticipated from chemical interaction between aggregate and cement. This, however, is a matter which requires further consideration, should any decision be reached to construct a dam in the Bakhshabad Tangi.

11.19 There is no doubt whatever that the Bakhshabad Tangi is more favourably placed in regard to aggregate materials than that at Aliki Nai. 


\section{CHAPTER 12 - ALIKI NAI DAM SITE}

$$
\text { (Maps 7,8) }
$$

12.1 In 1950 the Dutch engineer Tim de Jong favoured the construction of a dam on the Farah Rud just upstream of its confluence with the Aliki Nai, and indicated an alternative alignment which is about $500 \mathrm{~m}$. downstream, at the right-angle bend in the river. The writer favoured the N.N.W.-S.S.E. Tangi downstream of both of Tim de Jong's alignments. It is this more or less straight Tangi that was mapped by Mr. Purtaph Singh on the scale of $1: 2,000$ with 5-metre contour intervals. This topographical map is the basis for the geological map accompanying the present report.

12.2 It has not been possible to givd a definite single geological succession of the volcanics of this Tangi, since the left and right banks have different lavas and pyroclastics, and major faulting runs along the bed of the river. The rightbank volcanics have not been seen in undistrubed contact with those on the left, but they are regarded as younger, and as having been faulted down on the E.N.E. side relative to the volcanics on the left bank. The following is the composite succession:-

\begin{tabular}{|c|c|c|}
\hline 8 & $\begin{array}{l}\text { River Gravels } \\
\text { Terrace Gravels }\end{array}$ & \\
\hline 6 & $\begin{array}{l}\text { Basic Dykes } \\
\text { Acid Injection Complex }\end{array}$ & \\
\hline & $\begin{array}{l}\text { Right-bank Trachy-Andesites } \\
\text { Right bank Pyroclastics }\end{array}$ & contact not seen \\
\hline & $\begin{array}{l}\text { left bank Rhyolites } \\
\text { Left-Bank Pyroclastics }\end{array}$ & \\
\hline
\end{tabular}

12.3 The left bank is made up essentially of rhyolites resting as a tilted basin on a very variable group of pyroclastics, and injected in a complex manner with acid intrusive along fault zones. The right bank has what may provisionally be termed Trachy-Andesites, warped into a flat arch, with a core of pyroclastics, and injected with acid intrusive complex along more regular sills.

12.4 Cutting through the successions on both banks are swarms of basic dykes whioh are aligned close on north-south, and W.N.W.-E.S.E. Converging from both banks are faults which meet in the bed of the river in the vicinity of the dam's alignments. The fault on the left bank which comes in from the south is an inclined thrustfault. The complex pattern of faults in this region is best seen in Map No. 7, which accompanies this report. The majority of the faults are aligned north-south to N.N.W.-S.S.E., but there are others with an east-west trend. A considerable amount of this faulting appears to be related to the intrusion of Granodiorite masses and the Acid Intrusive complex.

\section{Lithology}

12.5 Starting with the left bank, may be noted the very variable group of pyroclastics, which are present sometimes as well-bedded ashes and minor lavas, such as occur on the southern scarp slope of survey station 35, and sometimes as thick unbedded agglomerates, such as are well exposed in the stream which joins the left 
bank of the Farah Rud near Bench Mark 5, with arbitrary contour level $200 \mathrm{~m}$. In this stream may be seen large blocks of lava and partially cemented ashes embedded in an ash matrix, and it is evident that there must have been a quite local volcanio vent to have supplied such great masses of explosively ejected material. This pyroclastic group extends as an interrupted outcrop down to the left bank of the river just upstream of the possible alignments, and must be present below the river sands under the alignments. Unlike the massive agglomeratic lava, or metasomatised agglomerate, of the Bakhshabad Tangi, the pyroclastic rocks of the Aliki Nai area are frequently not cemented, and are likely to possess a considerable matrix porosity and permeability.

12.6 Overlying these pyroclastics is a pinkish-weathering Rhyolite which forms the left bank at the dam site. The Rhyolite occurs as a tilted basin or saucer which ends on the north side against a sharp arch. Although the regional trend is that of an easterly dip, the actual left abutments of the alternative dam sites are of westerly-disposed Rhyolite on the east flank of the tilted basin. The basin and downstream arch must be strongly faulted against the volcanics of the right bank, which dip northwards, eastwards and southwards in relation to the domelike structure exposed in the main tributary on the right bank. The Rhyolite of the left bank has a micro-crystalline ground-mass of quartz and feldspar, with feathery patches of ferric oxide and phenocrysts of turbid Orthoclase. It is highly jointed into sharp splintery masses. Permeability will be confined to the joints.

12.7 The pyroclastics exposed in the core of the right bank dome are not seen in juxtaposition with the presumed older rhyolites of the left bank, and it is not known at what depth on the right bank the left bank rhyolites may be expected. The greater part of the right bank is composed of several distinct flows of TrachyAndesite lava, some of the flows having a very variable thickness. Within a horizontal distance of about 400 metres on the north bank of the main tributary two lava flows change in combined thickness from 80 metres on the west side to 10 metres on the east side. The lowest of the flows appears to rest with unconformity on westerly-dipping celadonitic ashes. Under the microscope these lavas have a ground-mass of parallel feldspar laths and some $30 \%$ of floculated iron oxide, with phenocrysts of pink feldspar up to $3 \times 10 \mathrm{~mm}$. in dimension. Between the lava flows are thinner bands of poorly exposed ashy material. Injected conformably within the lavas are several sills of white to brown weathering acid intrusion, in a regular manner which is quite distinot from the confusion of injection and host material intruded along faults which prevail on the left bank. The Trachy-Andesite will have no matrix permeability, but there will be joint-permeability.

\section{Alternative Alignments}

12.8 There are three alternative alignments within a reach of the river which is 500 metres long; one downstream of the major tributary on the right bank, and two upstream thereof. Mention will also be made of the two alignments suggested by Tim de Jong in 1950.

Base Length at river level

Lower \begin{tabular}{l} 
Length at \\
$+60 \mathrm{~m}$. \\
\hline
\end{tabular}

$450 \mathrm{~m}$.

\section{Geological formation}

Much faulted left bank. Concealed faults in river bed. Aoid Injection zone on right bank at river level. Sound right abutment, part of main hill mass. 


\begin{tabular}{|c|c|c|c|}
\hline & $\begin{array}{l}\text { Base length } \\
\text { at river level }\end{array}$ & $\begin{array}{l}\text { Length at } \\
+60 \mathrm{~m} . \\
\end{array}$ & Geological Formation \\
\hline Middle & $160 \mathrm{~m}$. & $480 \mathrm{~m}$. & $\begin{array}{l}\text { Reasonably sound rhyolites on } \\
\text { left bank in form of basin. } \\
\text { Concealed faults in river bed. } \\
\text { Acid injection complex in lower } \\
\text { part of right abutment. At } \\
+60 \mathrm{~m} \text {. right abutment only } 70 \mathrm{~m} \text {. } \\
\text { wide. }\end{array}$ \\
\hline
\end{tabular}

Upper $\quad 150 \mathrm{~m}$. $\quad 470 \mathrm{~m}$.

Reasonably sound left abutment but greater dam volume to $+60 \mathrm{~m}$. Concealed faults in bed of river. At $+60 \mathrm{~m}$. the right abutment is $135 \mathrm{~m}$. wide.

Tim de Jong Aocurate figures not available Lower

Tim de Jong Upper
$160 \mathrm{~m}$. gravels approx. $500 \mathrm{~m}$.
Left abutment steeply dipping rhyolite. Isolated rock outorop in bed of river. N.N.W.-S.S.E. faults expected in bed and on right side. Broken ground on right abutment. River makes two bends near dam site.

Left abutment slopes $10^{\circ}-14^{\circ}$, up to hill $58 \mathrm{~m}$. above river level, but lower saddles exist beyond. Major fault in river bed. Right abutment steep. Aliki Nai tributary joins Farah Rud just downstream of alignment.

12.9 The lower site has a sound right abutment against the undissected hill which is present downstream of the right bank tributary. But the left abutment is in a broken condition, with steep dips in the rhyolites, and a considerable degree of faulting. The middle and upper sites have as their right abutment the left bank of the main tributary, an abutment which tapers off towards the north into a narrow and unsatisfactory ridge. At an elevation of $+60 \mathrm{~m}$. relative to L.W.L., the right abutment is only $70 \mathrm{~m}$. wide in the case of the middle alignment, and $135 \mathrm{~m}$. wide in the case of the upper alignment. There is no doubt that the upper alignment is superior to the middle one in having a wider right abutment, with a longer percolation path towards the east into the right-bank tributary. This upper alignment would have a deeper section on the left side since it has not the advantage of the steep left abutment which is present in the middle one.

12.10 All three alignments will be involved in strong faulting along the bed of the river, and in all of them it may be anticipated that the probably pervious agglomerates will be present below the river gravels on the left side. The $160 \mathrm{~m}$. width of river gravels and sands conceals much of the critical geology in this Tangi, but, in addition to the faults it may be anticipated that there is a considerable amount of acid injection material, such as is well seen exposed at the downstream end of the Tangi on the right bank. The cross section of the middle alignment is an 
attempt at showing the possible structure, but the writer freely admits that it is difficult to prepare a convincing section of these volcanic rocks which in plan are found to be intersected to such an extent by faults and anomalous discordant contacts.

12.11 The lower of Tim de Jong's alignment would be located at the right angle bend in the Farab Rud a short distance downstream of its confluence with the Aliki Nai. At this bend there is an isolated hillock of rock in situ which has the bedded appearanoe of a rhyolitic ash, or banded tuff, but which in thin section under the microsoope gives the impression of being a flow-banded spherulitic rhyolite with phenocrysts of orthoclase. The presence of this outcrop would suggest that the river sands and gravels are not of great depth. The right abutment of this alignment would be located over topographically irregular ground, with considerable disturbance by N.N.W.-S.S.E. faults.

12.12 The alignment actually studied by Tim de Jong has a steep right abutment of massive rhyolite resting on bedded ashes, some of which are coloured bright green, possibly with the mineral celadonite. It is likely that the same rhyolite is present on the left bank where it dips gently E.N.E. towards the river, and must have been severely faulted down by a displacement exceeding 100 metres. The left abutment slopes upwards with a gradient between $1: 4$ and $1: 5.7$ to a hill which is about $58 \mathrm{~m}$. above river level. This hill forms part of a ridge with saddles that are probably only 35-40 m. above river level, and a dam between 50 and 60 metres in height above L.W.L. would necessitate the construction of dykes on each of the saddles. Finally, the Aliki Nai stream enters the Farah Rud just downstream of the alignment, from a catchment which is of the order of $150 \mathrm{Km}^{2}$ in area. This stream would have to be diverted in order to avoid erosion of the downstream toe of the dam in time of flood.

Excavation Grade in River Bed

12.13 It is difficult to guess the thickness of the river gravels along the main Tangi. The gravels are never less than 150 metres wide, and it is very probable that they would have an average depth of the order of 10 metres. In view of the amount of faultine which is anticipated in the rock bottorn of the river and the inferred disturbed nature of the rocks, it is likely that excavation grade would have to be some depth below the base of the river sravels, and possibly 15-20 metres below low water level. This would make a total height of the dam 75-80 metres. The volume of concrete dam constructed in the lower Tangi would be virtually double that of a dam located in the Bakhshabad Tangi. R. Caspar is, however, in favour of a rock-fill structure in the Aliki Nai Tangi. River gravels are probably thinner in the part of the river examined by Tim de Jone; particularly at his lower alignment.

Spillway for the Three Lower Dams

12.14 A natural spillway exists on the left bank which could be utilized by a dam constructed in the three lower alignments, in the main Tangi. This is in the form of a narrow depression running almost north-south about 400 metres west of the centre of the Farah Rud, along which there has been faulting and injection of acid magma. The rocks of this acid injection zone are considerably weathered, and would be easily eroded in the event of a major flood discharge. From the most northern saddle along this depression to the Farah Rud downstream of the dam alignments the gradient would be about $1: 17$. The lining of this weak and weathered zone is likely to be costly. 


\section{Raw Materials for Construction}

12.15 Small terraces of river gravels occur on the left and right banks of the Tangi, but the gravels attain no significant thickness. The left bank terrace, upstream of the three lower alignments, has an area of approximately $65,000 \mathrm{~m}^{2}$, and it is doubtful if the volume would exceed $200,000 \mathrm{~m}^{3}$. It is necessary to 80 from 4 to 5 kilometres upstream before an important terrace is reached on the left bank, just downstream from the confluence of the Rhodedoz stream with the Farah Rud. These terrace gravels consist of pebbles, cobbles and boulders set in a sandy matrix with a calcareous cement. The coarse aggregate consists of volcanic rocks, limestones, shales, calcareous sandstones, together with minor amounts of granodiorite and basic intrusive material.

12.16 The major granodiorite massif of the Aliki Nai pluton crops out 3 air kilometres S.W.S. of the dam site Tangi, and an access road or aerial ropeway could be constructed without much difficulty. In a north-east direotion there is an outcrop of oretaceous limestone 6.5 air kilometres distant from the Tangi, but access to this limestone massif would be difficult. If non-volcanio rock is to be quarried, the granodiorite massif is preferable.

12.17 The nearest source of rock is in the volcanios on either side of the Tangi. The lavas, however, are strongly jointed, and crushing would result in very angular and splintery blocks, which are unlikely to be suitable for concrete aggregate, but might be used in a rock-fill structure with allowance for considerable settlement. A large amount of weathered material would be available from excavations in the acid injection zone of the north-south spillway channel (paragraph 12.14).

12.18 The immediate area of the dam site has little impervious material, as the terrace gravels have few silt or clay lenses. Shale crops out interbedded with lavas in the Rhodedoz sliver about $9 \mathrm{Km}$. S.S.E. of the Tangi. There are also shales below lavas and pyroclastics in outcrops 3 to $4 \mathrm{Km}$. N.N.W. of the Tangi, close to Ghodeghazak village, where the dip of the mixed volcanics and sedimentary rocks is $25^{\circ}$ to $30^{\circ}$ in a S.S.E. direction. 


\section{CHAPTER 13 - ILASHKAR GHAR DAM SITE \\ (Maps 9,10)}

Introduction

Date of Examination

13.1 The site was visited in the company of the Project Manager and three topographical engineers between October $11 \mathrm{th}$ and 19th, 1962. The topographers stayed on at Lashkar Ghar in order to complete the topographical map on the scale of $1,2,000$. The writer was out of Afghanistan on other assignments for a period of 8 months from November 2nd 1962 until June 16th 1963, and it was not possible to return to Lashkar Ghar in 1963 with the completed topographical map and make a detailed geological study.

13.2 If the Lashkar Ghar site had been regarded as the most important of the three sites on the Farah Rud, it would certainly have been necessary to have visited it once again for detailed geological mapping. Since, however, the Lashkar Ghar gorge is very remote, and a dam located there would be less economical than one at Bakhshabad, it was considered sufficient if the geological details obtained from the 1962 reconnaissance were inserted on to the topographical map, without actually making a second visit to the gorge. Moreover, no visit could be made there at that time of year on account of absence of camel transport; it is very probable also that the river discharge of the Farah Rud would have been too high in mid-1963, due to the relatively high rainfall which occurred during the early months of the year, for access to the gorge without carrying a boat.

13.3 It should be stressed, therefore, that the present report is based on a reconnaissance which was made 9 months previously, before the topographical map of the gorge had been made, and that there is a concentration on the weak zones rather than a delineation of the many varied types of limestone, marl and shale which are present at the dam site, and could only be satisfactorily demarcated when a topographical map is actually available and used in the field. There must inevitably be a loss of memory concerning many of the geologioal features, but it is hoped that the essential structural elements and relationships have not be omitted, or distorted due to the lapse of time.

Aocess

13.4 The Jeep track beyond Shaharak was first reconnoitred in 1961 by the Hydrological group, U.N.S.F. The track goes from Farah to Dehzak and east to Shaharaks $82 \mathrm{Km}$. It orosses the USSR road alignment between Shindand and Dilararn just east

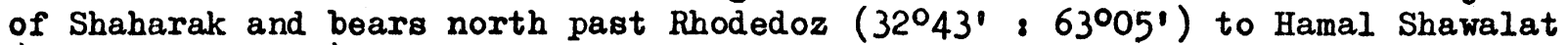
(32051', 63015'): distance $65 \mathrm{~km}$. Wuch of this is along wadi beds and over rough volcanio terrain. From Hamal Shawalat it is necessary to walk the remaining $31 \mathrm{Km}$. to the camp, about $1 \mathrm{Km}$. downstream of the Lashkar Ghar dam site, with two fordings of the Farah Rud. A construction road from the Soviet highway near Shaharak to Lashkar Ghar would be approximately $100 \mathrm{Km}$. in length, and would involve 2 bridges over the Farah Rud. 
13.5 By travelling overnight the $524 \mathrm{Km}$. from Kandahar airport to Farah town, and making a double march between Hamal Shawalat and Lashkar Ghar, the journey between Kabul and the dam site can be undertaken in 3 days. Supplies are scarce in this sparsely populated area, and animal transport (mainly camel but sometimes donkey or cow) is usually very difficult to obtain.

\section{General Geology}

13.6 The succession of formations in the Lashkar Ghar area is as follows:-

Period

4. Recent to Pleistocene

3.? Oligocene Eocene

2. Cretaceous

1. ? Lower Cretaceous to Jurassio

? Oligocene
Approx. Thiokness

up to $30 \mathrm{~m}$.

up to $2500 \mathrm{~m}$.

more than $1000 \mathrm{~m}$.

several $1000 \mathrm{~m}$.

Intrusions
Modern River Gravels Terrace Gravels

Farah Volcanic Series: basic to acid lavas; ashes; tuffs; agglomerates: together with interbedded sedimentary conglomerates, sandstones, shales and marls.

Massive creamy white limestone with abundant Rudistes; marly limestones; sandy limestones; shales. Some zones crowded with Orbitolina.

Flysch; shales; calcareous shales; calcareous sandstones; thin limestones.

4. Basic dykes in swarms orientated NNE-SSW within the Flysch of the Nizgan area (33008';63032').

3. Granopyhric intrusions within the Farah Volcanics, as sills, dykes, and probably as a core within a major intrusive centre at $32^{\circ} 42^{\prime}$ : $63^{\circ} 19^{\prime}$, on the upper Malman, with a surrounding rim of basic to ultrabasic rocks.

2. Granodiorite to gabbro intrusions in the Aliki Nai - Shaharak area.

1. Ring Intrusions of Trachyte within the lower part of the Farah Volcanic series near Malman-Farah confluence. 
13.7 The Flysch lies on the north side of Lashkar Ghar and has not been examined in this area. It occupies the broad valley of Nizgan ( $33^{\circ} 09^{\prime}: 63^{\circ} 33^{\prime}$ ), and extends southwards to the foot of the limestone scarp. It probably crops out along the Farah Rud within the major anticline which is seen on the air photographs, and may come to within $5 \mathrm{Km}$. north-west of the dam site at the pitching end of the anticline. Flysch is also suspected within the core of the dome which occurs 7.5 to $10 \mathrm{Km}$. W.S.W. of the dam site.

13.8 The Flysch is cut through by swarms of basic dykes orientated NNE-SSW, 8 dykes being exposed within an east-west distance of $3.25 \mathrm{Km}$. The direction of dykes is coincident with that of the major faults which cut up the limestone into prisms.

13.9 The Farah Volcanic series lies within a syncline, flanked on the west, north and east by highly folded and fractured Cretaceous limestone. The folds in the Cretaceous are orientated N.W.-S.E. to NNW-SSE, whereas the basin of Farah volcanics has a long axis aliened NNE-SSW, virtually orthogonal to the folds in the Cretaceous rocks.

13.10 Much of the boundary between the Farah Volcanics and the underlying limestone is probably a violent stratigraphic unconformity. The Cretaceous limestone and Flysch were evidently strongly folded and then succumbed to active erosion, with the formation of extensive limestone conglomerates and the simultaneous eruption of the first of the lavas.

13.11 Elsewhere the boundary between the limestone and volcanics, where conformable or unconformable, has been disturbed by overfolding, as north-west of the MalmanFarah confluence, and by overthrusting E.S.E. of Lashkar Ghar.

13.12 The Lashkar Ghar dam site is looated within the Cretaceous limestone group, in contrast to the sites at Aliki Nai and Bakhshabad which are within the Farah Volcanio series.

13.13 The Cretaceous limestone series has been broken up by almost north-south faults into a series of rectangular prismatic masses. Some of these faults are probably normal, but those around Lashkar Ghar are of an overthrust nature, the direction of movement of the over-riding blocks being from east to west. One of these faults occurs within the gorge, just downstream of the dam site, and will be described in paras 17,18. The most pronounced overthrust fault lies $1.2 \mathrm{Km}$. east of the dam site and brings Cretaceous limestone to rest with strong tectonic discordance upon different lava flows and interbedded sedimentary rocks of the Farah Volcanic series. About $2 \mathrm{Km}$. south-east of the dam site the overthrust can be seen to truncate a syncline of red sediments belonging to the volcanic series. These faults extend northwards and must cross the Ghor Rud, running parallel with the dykes of the Flysch swarm.

13.14 The fracture pattern, and presumably the dykes, originated towards the end of the volcanic episode, perhaps during the Oligocene.

13.15 There is no evidence that any of these faults has displaced the terrace gravels, and it may be accepted that the faults are dead and not seismic. 


\section{Detailed Geology of the Gorge}

13.16 The gorge in which the dam would be located is cut through Cretaceous limestones. Some of these limestones are dense, massive, pink, cryptocrystalline and almost monolithic. At the entrance to the gorge from the south the dip slope on the right bank is seen to be full of Rudistes fossils. There are however beds of less massive marly limestone and calcareous shales, often crowded with Orbitolinas, and frequently with a reddish colour.

13.17 Broadly, the limestone group has been folded into a sharp compressed synoline on the west side and an acute anticline on the east side. The common limb between the syncline and the anticline has been severed by a major reversed fault orientated NNE-SSW, which has resulted in the east side rising relative to the west side.

13.18 On the south side of the gorge there is a narrow band of volcanics located along the fault, the sequence from west to east being:

(a) massive limestone of the gorge syncline

(b) narrow zone of Farah Volcanics

(c) massive limestone of the gorge anticline.

The volcanic wedge is not seen at river level or on the left (north) bank. Instead, at river level, there is a zone almost $40 \mathrm{~m}$. in width of highly broken limestone. The original bedding planes in this zone have been obliterated, and replaced by vertical sheared lenticular slivers.

13.19 Further west, near survey station 6 , the limestone of the west limb of the syncline has been dropped down by a series of normal faults.

\section{Location of Dam}

13.20 The only possible location for a dam in the Lashkar Ghar gorge is along a section of the river 100 metres in length which is west of the major thrust fault zone, and east of the group of normal faults. This part of the river lies between survey stations 5 and 6 . Both upstream and downstream of the fault zones the gorge becomes wider and there are complications with the presence of the marly fossiliferous beds, along almost all of which severe shearing has taken place.

13.21 The 100 metre section has almost monolithic limestone on both banks, the rather obscure bedding planes suggesting that the narrowest section of the gorge is cut through the axis of the syncline.

13.22 The river is 29 metres wide in the narrowest part, and the chord length for a dam 90 metres in height is about 150 metres. Crest elevation would be at the arbitrary survey contour $145 \mathrm{~m}$. If a thick-arch type of dam is assumed, with a radius of 120 metres, and centre 48 metres ESE of survey station 5, the arc length would be about 162 metres. These figures are of course based on present topography, and do not take into account the stripping which would be necessary to reach foundation grade (paragraph 13.26).

13.23 On the south bank there is a very pronounced N.W.-S.E. gully, occupied by a shear zone, which runs from river level near station 6 for 130 metres in a southeast direotion and joins up with the major thrust fault. Along the provisional chord location suggested for the dam alignment this shear zone would be 60 metres south of the abutment at river level and about 25 metres at crest level from the south end of the dam. 
13.24 It would be possible to construct a dam 100 metres in height from river level, up to arbitrary contour $155 \mathrm{~m}$., but the right abutment becomes very thin at this elevation and it is doubtful to what extent it could take arch-thrust action in the topmost levels. Provisionally it may be suggested that it would be wiser to limit the height of the dam to $90 \mathrm{~m}$. above present bed level.

13.25 The depth of the river gravels is not known. In many gorges of this type the gravels are much thicker than the narrowness of the gorge would suggest on purely topographical considerations. The writer has recently seen the Keban dam site on the Euphrates (Firat) River in central Turkey. The river runs through an incised inner gorge about $60 \mathrm{~m}$. wide within the main much wider valley, and thickness of gravels below the river is $35 \mathrm{~m}$. The kuphrates is of course a major river, and was running about $3,000 \mathrm{~m} / \mathrm{sec}$. at the time of the writer's visit on 4.6 .63 , so that no exact comparison can be made with the Farah Rud. But even a rare exceptional flood of say $2,000 \mathrm{~m} / \mathrm{sec}$. On the Farah Rud could cause much scour in the Lashkar Ghar gorge, and it is possible that the gravels in the gorge may attain a thickness of 10 metres. This supposition will naturally have to be ohecked by boring in the bed of the river.

13.26 It is not considered that much stripping will be required at the lower levels on either abutment. The slope of the left abutment becomes gentler above arbitrary contour 120 (65 m. above river bed level) and it is probable that stripping above this elevation on the left abutment will be greater. At the lower levels for the purpose of preliminary design $5 \mathrm{~m}$. stripping on either abutment may be assumed. Above the 120 contour a provisional $10 \mathrm{~m}$. may be accepted, making the chord length at crest elevation about $170 \mathrm{~m}$.

\section{Raw Materials for Construction}

13.27 It is assumed that the dam will be constructed of concrete and may be of aroh type. Depending on the design, whether arch-gravity, arch or thin arch, the volume of the dam might vary from $400,000 \mathrm{~m}^{3}$ to $100,000 \mathrm{~m}^{3}$. It is necessary therefore to consider a source of material that might yield up to about $500,000 \mathrm{~m}^{3}$ of aggregate, if the most conservative design were adopted.

13.28 The gravel terraces at the camp site downstream of the gorge contain large boulders of limestone, $30-40 \mathrm{~cm}$. in diameter, enclosed within more typical conglomerate containing smaller cobbles of limestone, flaggy calcareous sandstone, flaggy calcareous shales, and some volcanics.

13.29 The terrace by the camp site is $100 \times 260$ metres in area and may have an average thickness of gravels of 8 metres. Combining this terrace with the lower one it should be possible to obtain $250,000 \mathrm{~m}^{3}$ of material. Some of this terrace material is cemented, and would require blasting for extraction. The larger limestone boulders would have to be crushed.

13.30 The present river gravels are also extensive. In the vicinity of the camp these gravels have mainly limestone cobbles, although there are numerous flaggy calc-sandstones and shales derived from the Flysch outcrops upstream of the gorge. There are also a few volcanic pebbles, but not to the same extent as further south after the. Farah Rud has flowed for some distance over the Volcanic series. The river gravels are uncemented. 
13. 31 There is no doubt that within the distance of one kilometre along the northsouth reach of the Farah Rud by the camp site enough material will be found within the gravel terraces and river gravels to provide coarse aggregate for the dam concrete.

13.32 In both the terraces and river gravels limestone boulders are in considerable excess, but it is not known if the more flaggy and shaly material derived from the Flysch would come volumetrically within the permissible limits for direct use of the deposits without selection and rejection of the unsuitable rock types.

13.33 The massive limestone would make suitable and more consistent aggregate on quarrying and crushing.

13.34 No beds of clean sand were however found which could be used as fine aggregate for the concrete mix, and it is probable that the gravel material will have to be orushed in order to produce the fines.

\section{Exploration}

13. 35 Three borings will be required in the bed of the river at the dam site, between survey stations 5 and 6 , in order to test the thickness of the gravels.

13. 36 At least two tunnels will be required on each abutment, making a minimum of four tunnels, in order to study the joints, shears and faults within the limestone. The tunnels on the right (south) bank will have to be driven far enough to reach the prominent weak zone which is orientated N.W.-S.E. (paragraph 13.23).

13. 37 Test pits will be required in the gravel terraces and river gravels in order to study the composition of the constituent cobbles and pebbles, and the proportion of unsuitable rock types.

\section{Conclusions}

13. 38 The limestone gorge at Lashkar Ghar is suitable for the construction of a concrete dam. It may be just possible to accommodate a dam 100 metres in height above present bed level, but topographically and geologically the right abutment between 90 and 100 metres above river level is thin and probably unsuitable to take arch thrust. A safer height for the dam would be 90 metres above river level, and possibly 100 metres above foundation level at the bottom of the river gravels.

13.39 The area is tectonically highly disturbed, but there are no indications that the numerous faults and overthrust faults are still in active condition. Those dislocations which are found in the dam abutments will require engineering treatment, like any other weak zone, but they are considered to be static and dead. The massive limestone, within the 100-metre length of the river which has been selected as suitable for construction, appears to be sound and almost monolithic.

13.40 For concrete aggregate the choice lies between crushing the massive limestone, or exploitation of the river gravels and gravel terraces. These gravels have predominant limestone boulders but there are some deleterious constituents. The larger boulders in the gravels would require crushing.

13.41 An access road from the recently completed Soviet highway would be about 100 $\mathrm{Km}$. in length, and would probably involve the construction of two bridges across the Farah Rud.

13.42 Investigation by means of borings and tunnels will be required. 
CHAPTER 14 - CONDITIONS OF WATER-TIGHTNESS IN THE THREE

RESERVOIR BASINS

\section{Bakhshabad Reservoir Basin}

14.1 The reservoir which would be impounded by a dam at Bakhshabad $60 \mathrm{~m}$. in height above low-water level would extend about $23 \mathrm{~km}$. straight distance upstream, to the head of the Aliki Nai Tangi. Noving from west to east up the Farah Rud, the following prinoipal structural features may be noted:

(a) N.E.-S.W. Bakhshabad synclinal axis which runs about $1.6 \mathrm{Km}$. N.W. of the Bakhshabad dam site and $2.5 \mathrm{Km}$. S.E. of Bakhshabad village.

(b) W.N.W. (downstream) dips in the volcanic succession for a distance of $7.5 \mathrm{Km}$., of which $5.5 \mathrm{Km}$. would be covered by the reservoir.

(c) North-South anticlinal axis exposing Flysch outcrops below the volcanics.

(d) Easterly (upstream) dips in volcanics as far as the Robai Turkan synclinal axis which muns through the piedmont slope east of Robai Turkan.

(e) Westerly (downstream) dips in volcanios as far as the Flysch and limestone-conglomerate anticline which runs north-south at the north end of the Aliki Nai plutonic mass.

(f) South-east dips in a mixed volcanic plus Flysch-type facies around Ghodeghazak village on the north bank of the river, about $3 \mathrm{Km}$. N.E. of the Aliki Nai dam alignment. These rolcanics and inter-trappean sediments are disposed as flat folds with N.E.-S.W. axes, and appear to be abruptly truncated by the faulted block of volcanics of the Aliki Nai Tangi on the Farah Rud (Photograph 8/14449).

(8) The fault-block of the Aliki Nai Tangi lavas is bounded on the north by an east-west fault, and on the west by a north-south fault which is part of the sliver munning for $6 \mathrm{Km}$. in a south direotion from the Farah Rud along the east flank of the Aliki Nai pluton (photo 8/14450). The detailed geology within this fault block is very complicated, as may be seen from the geological map of the Aliki Nai dam site, but the broad trend of the lavas is to dip in an E.N.E. direction away from the right bank of the river.

14.2 The greater part of the Bakhshabad reservoir would be located upstream of the anticline mentioned in paragraph 14.1 (c) above, and would cover alternations of anticlines and synclines, with anticlinal cores which are composed of either Flysch, or mixed Flysch facies cum voloanios. The structural grain is mainly north-south across the length of the reservoir, and any percolation into porous members of the 
voloanics would be inhibited from taking a course outside and downstream of the reservoir by the east-dipping limbs of the (c) and (e) anticlines. The major Flysch outcrop running to the south and west of Robai Turkan would prevent lateral migration of water to the south from outside the reservoir basin.

14.3 The lowest $5.5 \mathrm{Km}$. of the Bakhshabad reservoir would, on the other hand, be looated on downstream-dipping volcanics consisting of lavas, ashes and celadonite (?) beds, and this disposition must be regarded as providing potential zones of percolation from the reservoir westwards towards the axis of the Bakhshabad syncline.

14.4 The voloanic jile in this lowest part of the Bakhshabad reservoir is, however, broken up by abundarit intrusions, of two main kinds:

(a-i) Major acid intmusions, standing out as white masses in the air photographs. These intrusions are sometimes of sill type, running between the lava flows, but even the sills are demonstratably discordant to the lava flows, as may be well seen on the north bank of the Farah Rud, just opposite the camp occupied by the writer in November 1960. Other acid intrusions are in the form of vertical dykes, and feeders to the sills.

(a-ii) The acid intrusive complex is fundamentally part of the acid intrusions mentioned in $(a-i)$ above, but is more contaminated with mega-xenoliths of host lavas. Where this acid intrusive complex was studied on the south-east side of the Farah Rud at the Bakhshabad dam site it is transgressive against contiguous volcanics.

(b) Swarms of basic and prophyry dykes, with a prevalent direction varying from E.S.E. -W.N.W. to S.E. - N.W. The spacing of the dykes in these swarms varies, but in some exposures on the north bank of the Farah Rud it is as close as 1 dyke every 10 metres. Some of these dykes extend several kilometres, but in general individual dykes are less extended, but follow each other in echelon fashion. The dykes are either vertical or have steep dips of the order of $70^{\circ}$. The box-work pattern of basic dykes permeating the lavas is well displayed on the north bank of the Farah Rud at the Gashakbar dam site.

14.5 The effect of this system of acid and basic intrusions is to convert the succession of lavas in the Bakhshabad-Gashakbar Tangi into a series of compartments, with walls of aoid and basio material. It is a reasonable assumption that the intrusions extend downwards to the bottom of the lava column and into the underlying Flysch. Indeed, the basic dykes are very well exposed in the Flysch and Limestone Conglomerate outorop, which underlies the Volcanics at the north end of the Aliki Nai plutonio mass, $4.25 \mathrm{Km}$. W.S.W. of the Aliki Nai dam site. 
14.6 While, therefore, the basio struotural disposition of the Voloanics in the Bakhshabad-Gashakbar tangi is one that might permit of leakage of water through the more permeable ash members where these would be exposed in the bed of the reservoir, the volcanics are in actual fact so infested and broken up by acid, intermediate and basic intrusions, that the channels for water migration must throughout the area be repeatedly interrupted by abrupt contacts with intrusive material. It would appear, therefore, to the writer that the walls of acid and basic igneous rocks are likely effectively to check such percolation as may occur from the lower part of the reservoir into the up-ended exposed ends of the lavas and ashes.

Aliki Nai Reservoir Basin

14.7 The Aliki Nai reservoir would probably extend up the Farah Rud as far as the confluence of this river with the Malman Rud. In the region between the Aliki Nai dam site and Rhodedoz village the volcanics are extremely intersected with major north-south to N.N.W.-S.S.E. faults. Some of these faults are evidently connected with the small granodiorite mass which lies $18-21 \mathrm{Km}$. south-east of the Aliki Nai/ Farah Rud confluence. Other faults appear to be related to the acid intrusive complex (? Granophyre) covering $55 \mathrm{Km}^{2}$ which is centred on coordinates $32^{\circ} 42^{\prime}$ : 63018 '.

14.8 The lowest $8 \mathrm{Km}$. of the reservoir would be located across fault slivers in which the dips vary from eastwards in the Aliki Nai Tangi, to E.S.E. in the Rhodedoz sliver, and north-east about $4.5 \mathrm{Km}$. E.N.E. of Rhodedoz village. These easterly dips are upstream, and such percolation as there may be in the more permeable members of the volcanics would be upstream into the river basin.

14.9 The upper $16 \mathrm{Km}$. of the reservoir would be located over the N.N.E.-S.S.W. Malman syncline, on the flanks of which volcanics are seen to rest upon Flysch-type shales and interbedded volcanics. The syncline is excellently displayed $3.5 \mathrm{Km}$. north of the confluence of the Malman with the Farah Rud, and the axis of this structure crosses and re-crosses the Farah Rud until, towards Rhodedoz village, it is severed and dislocated by tear faults. Percolation in this area would be into the syncline with its floor of mainly argillaveous sediments, and would be confined, therefore, to the priming of the porous ashes and rare sandstones, without loss outside the basin.

14.10 Consequently, it appears definite that the Aliki Nai reservoir would not be subject to significant water losses outside the limits of the basin. This disposition is more satisfactory than that which obtains in the lowest $5.5 \mathrm{Km}$. of the Bakhshabad reservoir. As has been suggested, however, the presence of abundant acid and basic intrusives in the Bakhshabad basin should very materially decrease the possibility of water loss from the lower reservoir, on account of the numerous impermeable barriers or membranes of intrusive rock with which the volcanics are there ramified.

\section{Lashkar Ghar Reservoir Basin}

14.11 The greater part of the Lashkar Ghar reservoir basin along both the Farah Rud and Ghor Rud would be located on outcrops of Flysch. Since all the lithological types of the Flysch have an argillaceous content, the formation may be accepted as being impermeable. The Flysch up these two valleys is intersected by a north-south dyke swarm but the dykes are irrelevant to the question of permeability and groundwater migration, since the sedimentary country rock into which they are intruded is 
as stated above itself impermeable.

14.12 The lower $15 \mathrm{~km}$. of the reservoir along the Farah Rud, and about $5 \mathrm{~km}$. of the (hor Pud, would however be located on Cretaceous Limestone, and it is with these limestones that there might be some concern. The limestones and associated marls and shales are highly folded and up-ended. The rivers flow across a sequence of beds from bottom to top of the Cretaceous succession, which essentially crop out as a rim to the basin of Farah Volcanic Rocks south of Lashkar Ghar. Consequently, there is a condition which would permit of water losses from the rivers into the limestones, should the environment be a karstic one.

14.13 As discussed in Chapter 7, evidence has not been obtained in south-west Afghanistan for the existence of karstio conditions, and rivers are not found to disappear when they pass over limestone outcrops. To achieve a more positive answer to the problem, and to determine if some part of the river discharge may be lost into the limestone outcrop, it would be necessary to undertake accurate gauging on the Farah Rud and Ghor Rud before they enter the limestone, and to gauge at Lashkar Ghar where the combined rivers leave the limestone and flow over the volcanics. 
CHAPTER 15 - TABUIATED COMPARISON BETWEEN BAKHSHABAD, ALIKI NAI

AND IASHKAR GHAR DAM SITES AND RE'SERVOIR BASINS

15.1 The following table summarises the major differences between the dam sites and reservoir basins of Bakhohabad, Aliki Nai and Lashkar Ghar:-

Bakhshabad

Acoessibility

dimensions of a concrete dam metres of concrete. alignment between Shindand and Dilaram.
Possibly 350,000 cubic

The Bakhshabad dam site is about $35 \mathrm{Km}$. from the recently surveyed road

\section{Ceological}

Terrain

Main geologioal defects

Raw materials

\begin{abstract}
Volcanic and pyroclastio.
\end{abstract}

Shatter zone along bed of river. The agglomeritio lava, or metasomatised agglomerate, is likely to be impermeable except for joint permeability. Lavas dip downstream at site but are interrupted by dykes and acid injection material.
The Aliki Nai dam site is about $55 \mathrm{~km}$. from the surveyed road alignment.

About twice the Bakhshabad volume, but a rock-fill dam would probably be construoted here.
Lashkar Ghar

Lashka of Gar would require an access road from the newly constructed Soviet highway of about $100 \mathrm{Km}$. length.

An arch concrete dam could be constructed but trans port of cement would be costly. A rook-fill dam is calculated by the design engineer to be $927,000 \mathrm{~m}$ in volume.

Volcanic and pyroclastic.

No alignment has two good abutments. The right abutments of two alignments are narrow at $+60 \mathrm{~m}$. elevation above LWL. Concealed major faults exist in the river bed. Permeable pyroclastics are probably present below river bed under left abutment.

Terrace gravels are distant. The local rhyolite would yield very splintery fragments on crushing. Good quality Granodiorite is available $3.5 \mathrm{Km}$. to the W.S.W.
Limestone, marl and shale.

There is a zone along the river $100 \mathrm{~m}$. in length which is relatively free from faults. Upstream and downstream of this zone numerous faults cut across the valley. The thrust fault on the downstream side displays $40 \mathrm{~m}$. of highly broken

Terrace and river Eravels are available downstream of the erore. Limestone could be quarried on both abutments as a supply for rockfill. limestone rock. 
Reservoir

\author{
Permeable elements in the \\ lowest $5.5 \mathrm{Km}$. of the \\ reservoir have a down- \\ stream dip, towards the \\ Bakhshabad synclinal axis \\ which is west of the dam \\ site. It is thought that \\ the acid and basic intru- \\ sions which out through \\ the lavas and pyroclastics \\ shculd act as impermeable \\ membranes to the down-dip \\ percolation and loss of \\ water.
}

The upper part of the reservoir would be based on impermeable Flysch. The lower $15 \mathrm{Km}$. of the Farah Pud flows over Cretaoeous limestones, but the general absence of karstio conditions in the region suggests that reservoir losses should be small. 
CEAPTER 16 - LOWER FARAH RUD

16.1 For $25 \mathrm{Km}$. downstream of Bakhshabad the Farah Rud maintains its incised course within Plio-Pleistocene gravels. At Urriah (32048' : 62043') the river lies about $25 \mathrm{~m}$. below the plateau of gravels. In the Wadi Zermadan there are two terraces, each $13 \mathrm{~m}$. in height, the depth below the gravel plateau thus being $26 \mathrm{~m}$.

16.2 The gravels consist of beds of conglomerate, sand and silt, which carry a variable, but always present, quantity of calcium carbonate cement. The presence of this cement in the is ravels, and of relatively impermeable silts and mudstones, and the absence of jointing, all indicate that permeabilities are probably low.

16.3 Further downstream the river ceases th be incised, and flows over a flood plain of its own modern gravels, flanked by low terraces of cultivated land. This flood plain and cultivated area is bordered to the north-west and south-east by outwash fans from the isolated hills and hill ranges which are present on either side of the valley. The coalescing outwash fans from the Mil Koh range reach a width of 7-8 $\mathrm{Km}$. The river deposits, terraces and outwash fans completely obscure the "solid geology" and it becomes a matter of speculation what formations underlie the valley.

16.4 The river continues its open course to the south-west of Farah town. About $15 \mathrm{Km}$. south-west of Farah road bridge the Plio-Pleistocene cemented gravels begin to appear in the bed of the river. About $40 \mathrm{Km}$. from the Farah road bridge, and

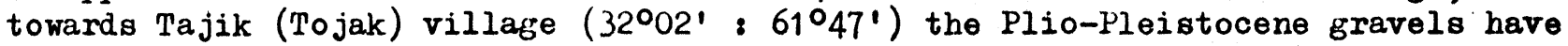
been warped up in the form of very flat swells, and have been incised by the river to a depth of 7 metres. A sequenoe in the oliffs is as follows:-

\begin{tabular}{|c|c|c|}
\hline \multirow[t]{2}{*}{ top } & $4.0 \mathrm{~m}$. & $\begin{array}{l}\text { gravels with thin beds of sands, } \\
\text { all cemented by calcium carbonate. }\end{array}$ \\
\hline & 0.6 & $\begin{array}{l}\text { grey ball-weathering calcareous } \\
\text { clayey silt. }\end{array}$ \\
\hline bot & 2.4 & $\begin{array}{l}\text { gravels with matrix of calcified } \\
\text { sandstone. }\end{array}$ \\
\hline
\end{tabular}

The warping of these Plio-Pleistocene beds has possibly taken place along northsouth axes, a direction strongly divergent from the ENE-WSW folds and faults whioh affect the Cretaceous limestones and Flysch.

16.5 Between the Tajik area and near Daulatabad there is an area $100 \mathrm{Km}$. in extent along the valley in which the Plio-Pleistocene gravels are submerged below recent river gravels and alluvium. The full thickness of the Plio-Pleistocene is not known as older bed-rock is never seen except towards the north-east edge of their outcrop, where the gravels overlie volcanics and Flysch, as near Urriah. A minimum thickness of $30 \mathrm{~m}$. must be assumed in the Wadi Zermadan area, and this may be exceeded further south-west.

16.6 In regard to the older bed-rock to the Plio-Pleistocene over the greater part of the Farah valley, it may be noted that the hills on the south-east side of the valley consist of Flysch with a folded capping of Cretaceous limestone. Six kilometres south-west of Dehzak the Flysch has no limestone cap, but is stronely contactmetamorphosed by granodiorite. The Koh-i-Safrak hill is a limestone dome ( $32^{\circ} 42^{\prime}$ : 
$62^{\circ} 33^{\prime}$ ), by inference with a Flysch core. The Bibcha Baran range which lies $20 \mathrm{Km}$. W.N.W. of Farah has the appearance of being a very tight anticline. When see, however, at the south-west end, (near coordinates 32027', 61053') vertical limestone is found to have been thrust towards the N.N.W., and it is probable that the anticline has been severed along the north-west limb. The hillock which is $17 \mathrm{Km}$. west of Farah town consists of Flysch that has been contact-metamorphosed into tough hornfels by the gabbro mass of Char-i-Tir-Koh.

16.7 From all these isolated exposures, and the virtually ubiquitous Fiysch, it may be suggested that Flysch probably forms the major part of the foundation to the Farah valley, together with minor intrusive masses. The conclusion which may be tentatively drawn, therefore, is that the sequence over most of the wide Farah valley is as follows, represented diagrammetically:-

Centre

\begin{tabular}{|c|c|c|}
\hline $\begin{array}{l}\text { Colluvial } \\
\text { outwash } \\
\text { fans } \\
\end{array}$ & $\begin{array}{l}\text { F'arah fud flood- } \\
\text { plain gravels } \\
\text { and terraces }\end{array}$ & $\begin{array}{l}\text { Colluvial } \\
\text { outwash } \\
\text { fans }\end{array}$ \\
\hline P1i & $\begin{array}{l}\text { leistocene cement } \\
\text { s, sands and silt }\end{array}$ & \\
\hline
\end{tabular}
Ranees
North-West

South-East Irregular Hills

Limestone, folded and thrust upon Flysch, with intrusions.
Limestone, folded and thrust upon Flysch, with intrusions.

16.8 The Flysch is impermeable. The Plio-Pleistocene gravels, sand and silts have a cement of calcium carbonate, and are not jointed. Consequently these beds should also have low permeabilities. The fact that the Plio-Pleistocene gravels are slightly unwarped south-west of Farah town indicates that the alluvial and cultivated terrain around Farah may be present in a shallow basin, and that the Tajik outcrops prevent migration of ground-water from the alluvium towards the south-west and Chakansor. These features must be taken into consideration in connection with drainage measures in case the cultivated lands are submitted to increased irrigation from water stored at Bakhshabad.

16.9 It is recommended that, in the event of an increase in supply of irrigation water, more studies should be made of the Farah plain downstream from Dehzak. Such a study will involve test boring down to a depth of 100 to 200 metres. A limited number of shallow refraction seismic profiles, across and along the valley, should be sufficient for the geometry of the superficial formations to be deciphered, dom to the inferred floor of Flysch. The seismic data should be oalibrated with the results of the test borings. 
PART III - PROJECTS ON THE HARI RUD

\section{CONTENTS}

Chapter 17 THE HART RUD VALLEY

$\begin{array}{lr}\text { Topography } & 1 \\ \text { Geology } & 5 \\ \text { Dam Sites on the Hari fud and } & 12 \\ \text { Kaoghan (Kawgan) } & \end{array}$

18 SALMAH DAM SITE

Location

Valley Faul.ts

Dam Site

Permeability of Right Bank

Type of Dam

Stability of Tectonic Faults

19 ASARISUM AND TASRA KAI DAM SITES

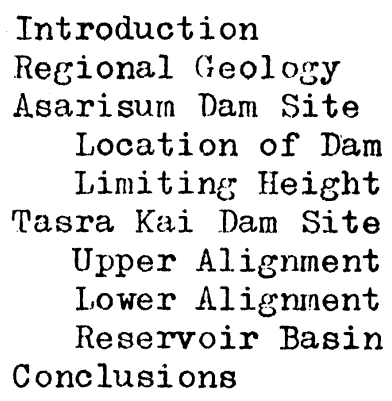

TANG-I-SHAH DAM SITE

$\begin{array}{lr}\text { Introduction } & 1 \\ \text { Location } & 5 \\ \text { Geological Succession } & 12 \\ \text { Lithological Characteristics } & 14 \\ \text { Regional Structure } & 33 \\ \text { Age of Faulting } & 40 \\ \text { Local Structure } & 44 \\ \text { Seismic Hazard } & 52 \\ \text { Location of Dam Axis } & 56 \\ \text { Leakage } & 63 \\ \quad \text { Reservoir Ba in } & 64 \\ \text { Area of Dam } & 69 \\ \text { Raw Materials for Construction } & 76 \\ \text { Conclusions } & \end{array}$




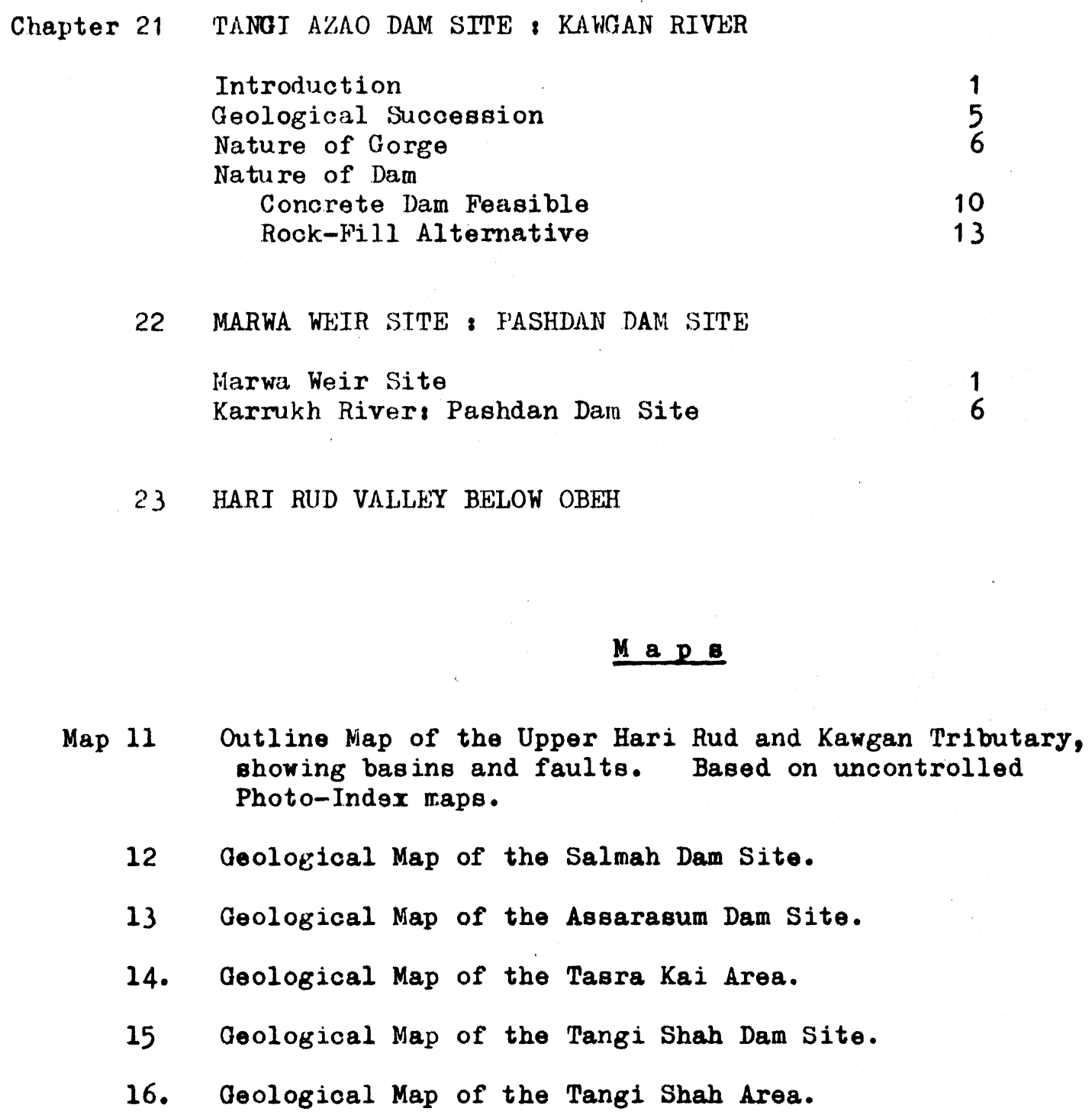

Map 11 Outline Map of the Upper Hari Rud and Kawgan Tributary, showing basins and faults. Based on uncontrolled Photo-Index maps.

12 Geological Map of the Salmah Dam Site.

13 Geological Map of the Assarasum Dam Site.

14. Geological Map of the Tarra Kai Area.

15 Geological Map of the Tangi Shah Dam Site.

16. Coological Map of the Tangi Shah Area. 
$\frac{\text { CHAPTER } 17 \text { - HARI RUD VALLEY }}{(\operatorname{Map~11)}}$

\section{Topography}

17.1 The Hari Rud has an east-west extent of $500 \mathrm{Km}$, or almost $6^{\circ}$ of longitude, before it turns north towards Soviet Asia. Its width in a north-south direction is much smaller. Including the important Kawgan (Kaoghan) tributary, the width is not more than $90 \mathrm{Km}$. The main Hari Rud may be divided into the following sections:-

1. Shahbash to Obeh: $160 \mathrm{Km} \cdot 3$ mainly an open valley, but with relatively narrow reaches that subdivide the valley into separate semi-basins. Gradient $2.5 \mathrm{~m} / \mathrm{Km}$. This is the main irrigable area.

2. Obeh to Zar-i-Darra: $80 \mathrm{Km} .3$ a narrow valley with some wider reaches which permit of limited storage. Gradient $5.4 \mathrm{~m} / \mathrm{Km}$. measured straight.

3. Zar-i-Darra to Shotor Khan: $90 \mathrm{Km} \cdot 3$ (or virtually between longitudes $64^{\circ}$ and $65^{\circ}$ ); the river occupies a deeply incised system of meanders. Very limited storage. Gradient $5.6 \mathrm{~m} / \mathrm{Km}$. measured straight. As an approximation, the meanders add $50 \%$ to the straight distance in the Zar-i-Darra to Shotor Khan section. The gradient as measured around the bends varies from 3.5 to $4.0 \mathrm{~m} / \mathrm{Km}$.

4. A zone of 4 basins, and tbree narrow tangis extending $90 \mathrm{Km}$. eastwards to east of Daulat Yar. Gradient $3.5 \mathrm{~m} / \mathrm{Km}$. measured straight.

5. Headwaters region, which has not been visited by the Special Fund team.

17.2 In regard to the Kawgan (Kaoghan) tributary, which enters the Hari Rud $25 \mathrm{Km}$. downstream of Obeh, the river is deeply incised, with poor storage potentialities, as far east as Tangi Azao. The average gradient over this reach, neglecting meanders, is $8.8 \mathrm{~m} / \mathrm{Km}$. Upstream of Tangi Azao the valley opens out into the Shararak basin, and there are few very narrow sections right up to the headwaters.

17.3 It is seen that both the main Hari Rud and its tributary have a zone where the river has cut deep valleys, with steep gradients, followed eastwards by wider valleys with gentler gradients. The zone of deep incision in the Hari Rud lies between longitudes $64^{\circ}$ and $65^{\circ}$, whereas that in the Kawgan is further west, between longitudes 63005' and 64011'. While Tangi Azao has an elevation of $2250 \mathrm{~m}$., the Hari Rud just to the north is as low as $1700 \mathrm{~m}$. It was thought feasible at one time during the writer's reconnaissance survey to divert the Kawgan water northwards through a tunnel and to utilise the 550 metre fall for power generation on the Hari Rud. This tunnel would, however, be about $17 \mathrm{Km}$. in length, and there would be long penstocks over difficult terrain. Such a scheme would, therefore, be very costly for the relatively small amount of water available at Tangi Azao (possibly 200,000,000 $\mathrm{m}^{3}$ ), and it has become evident from studies made by the irrigation engineers of the Project that the Tangi Azao water could be put to better use in conjunction with a dam at Tangi Shah, $100 \mathrm{Km}$. downstream on the same river. 
17.4 The disposition of the rivers is such, therefore, that the good storage basins occur only in their upper reaches, in remote terrains. The proposed Tangi Shah reservoir is an exception. This reservoir has poor capacity because it is in the narrow part of the kawran river. The exceptional narrowness of the gorge at Tangi Shah, and the apparent soundness of the rocks, has suggested however that an economical thin-arch dam could be constructed.

\section{Geology}

17.5 It is difficult to give any conneoted account of the geology of the Hari Rud valley because conditions vary rapidly, and only small isolated areas have been examined in any detail. The eastern part of the valley has certainly been controllod by post-Neogene faulting and folding. The main fault follows the north side for $70 \mathrm{Km}$., but further east it crosses the river to the south bank. The fault is associated with a mélange zone in which blocks of limestone are embedded within brecciated slate, shale, and purple conglomerate over a width of 500 metres.

17.6 Mesograde metamorphic rocks have not been seen east of Pul-i-Sher Khaj along the only route which was traversed. They are well exposed at Salmah, north of Obeh, west of Tangi Whah, and immediately north of Herat city. As stated in paragraph 3.4, the exposures at Tangi Shah indicate that the slates below the Cretaceous limestone are distinct from the mesorrade metamorphic rocks, against which they are faulted. Whether or not the group of dark slates and quartzites of Garmao $\left(34^{\circ} 29^{\prime}\right.$ : $65^{\circ} 3^{\prime}$ ) represent a less metamorphosed facies of the Metamorphics between Obeh and Herat cannot be determined on present evidence.

17.7 Lower Tertiary volcanic rocks are abundant east of longitude $64^{\circ} 55^{\prime}$. Where examined in the field they do not occur as large spreads of lava, but as more localised outcrops. In particular, the outcrops of pillow basalts, which occur at Asarisum and also $4 \mathrm{Km}$. north of the dam site, have the appearance of being the remnants of volcanic necks, injected within Flysch and Cretaceous sediments. More extensive volcanic outcrops do exist, however, on the north side of the Hari Rud. They were not visited, but were observed from the $10552 \mathrm{ft}$. col (3216 m.: $34^{\circ} 20^{\prime}$ : $64^{\circ} 5^{\prime}$ ) across the river in a north-west direction.

17.8 The chocolate, brown, grey and green-coloured conglomerates, sandstones and shales which are present over wide areas present a problem which has not yet been solved. On the south flank of the Paraponisus range, about $35 \mathrm{Km}$. north of where the Herat-Kushka road enters the hills, and again on the south side of the Hari Rud near Pul-i-Sher Khaj, there are exposures of steeply dipping conglomerates, sandstones and shales which may be of Mesozoic age. South of the Cretaceous Limestone at Tangi Azao there is a very thick series of chocolate-coloured sandstones, with minor conglomerates, reminiscent of the Miocene Murree beds of Pakistan and Dagshai beds of India. These beds are truncated and unconformably overlain by unquestionably younger Neogene fresh-water limestones, conglomerates and sandstones. The older beds may be Paleogene.

17.9 Between Langar and Tangi Shah, on the other hand, the steeply folded coloured oonglomerates, sandstones and shales, which lie as narrow down-faulted outorops within the Metamorphics, are suggestive of being Neogene sediments rather than Mesozoic. They rest across the Cretaceous limestone and underlying green and purple slates.

17.10 In the Asarisum and Tasra Kai areas, the Neogene is only gently tilted and warped over dome-like uplifts of limestone and volcanics, and covers and obscures very large areas. 
17.11 It appears, therefore, that there are three groups of conglomerates, sandstones and shales, all tending to display bright colours, and all probably of fluviatile nature:-

Young Neogene

Older Neogene, or perhaps Paleogene

Mesozoio.

Dam Sites on the Hari Rud and Kawgan

17.12 Three dam sites were investigated on the Hari Rud, and two on the major Kawgan (Kaoghan) tributary. These sites are as follows:-

\begin{tabular}{|c|c|c|c|c|c|}
\hline Dam Site & River & Coordinates & Elevation & $\begin{array}{l}\text { Approx. Road I } \\
\text { Herat }\end{array}$ & $\frac{\text { stance }}{\text { Kabul }}$ \\
\hline $\begin{array}{l}\text { Salmah } \\
\text { Asarisum = }\end{array}$ & Hari Rud & $34^{\circ} 20^{\prime} \cdot 63^{\circ} 49^{\prime}$ & $1580 \mathrm{~m}$. & $169 \mathrm{Km}$. & $684 \mathrm{Km}$. \\
\hline Assarassum & Hari Rud & $34^{\circ} 29^{\prime} \cdot 64^{\circ} 59^{\prime}$ & 2167 & 357 & 508 \\
\hline $\begin{array}{l}\text { Tasra Kai } \\
\text { Tangi Shah }=\end{array}$ & Hari Rud & $34^{\circ} 32^{\prime} \cdot 65^{\circ} 25^{\prime}$ & 2301 & 393 & 462 \\
\hline Tang-i-Shah & Kawgan & $34^{\circ} 10^{\prime}: 63^{\circ} 06^{\prime}$ & 1280 & $\begin{array}{l}84 \text { to Langar } \\
11 \mathrm{Km} \text {. march }\end{array}$ & \\
\hline Tangi Azao & Kawgan & $34^{\circ} 09^{\prime}: 64^{\circ} 11^{\prime}$ & 2250 & 237 & 616 \\
\hline
\end{tabular}

17.13 Of these sites, Asarisum, Tasra Kai and Tangi Azao are all at elevations exceoding 2,000 metres and are very isolated. Access is only possible during the summer months when the snow has melted. The wooden suspension bridge over the Hari Rud at Pul-i-Sher Khaj (180 road-Km. from Herat) is not in a safe condition, and the road eastwards from this bridge passes up a steep water course in a narrow ravine, liable to sudden imundation after storms.

17.14 In addition, the weir site at Marwa $\left(35^{\circ} 15^{\prime}, 62^{\circ} 56^{\prime}\right)$ was briefly examined, and a visit was made to the Pashdan site on the Karrukh tributary of the Hari Rud (34 $24^{\prime}$ 's $62^{\circ} 25^{\prime}$ ) which had been reported by Tim de Jong in 1950.

17.15 The usual procedure has been to make a separate report on each dam site. In the case of the Asarisum and Tasra Kai sites, however, a combined report was made, and both sites are discussed in the single chapter 19. Similarly, descriptions of Marwa and Pashdan are combined into Chapter 22.

17.16 One further dam site, at Tagau Kaza, should be mentioned on the middle reaches of the Hari Rud. This is located at co-ordinates $34^{\circ} 20.4^{\prime} \mathrm{N}$ : $63^{\circ} 40^{\prime} \mathrm{E}$ in topographical map 410-D/III, about $149 \mathrm{~km}$. by road eastwards from the Soviet highway at Herat. The site was briefly visited $b_{y^{\prime}}$ the German engineer Sakkit and was mentioned in a report issued from Sarobi in March 1952. Mr. Meade made a topographical survey in the oummer of 1961 and the site was visited in November 1961. The Hari Rud runs through Metamorphic rocks with a very variable cover of Terrace Gravels. At the Meade alicnment an outcrop of hornblende-gneiss occurs on the north bank up to a height of $30 \mathrm{~m}$. above river level, but on the south bank Terrace Gravels descend to within 10 metres of the river. The site was condemned on account of the abundance of Eravels which form a permeable cover. 
CHAPTER 18 - SALMAH DAM SITE

(Map 12)

Location

18.1 Maps $410 \mathrm{D} / 4,410 \mathrm{~F} / 2$

Air photographs $43 / 4048: 43-\mathrm{A} / 21501$

Coordinates $34^{\circ} 20^{\prime}: 63^{\circ} 49^{\prime}$

The dam site is located about $169 \mathrm{Km}$. east of the Soviet Highway at Herat kast, and is on the road from Herat to Shaharak, Lal, Panjao and Kabul.

Elevation: about $1580 \mathrm{~m}$, above sea level.

Period of Inspection

18.2 The site was visited for a few days in July 1963 in the company of the Topographical group of the U.N. Special Fund.

Valley Faults

18.3 The Salmah dam site is located within the Hari Rud Valley, the geological structure of which is extremely complicated. The valley is clearly partly controlled by east-west faults. In some parts of the valley there are faults along both sides of the river such as around Asarisum near longitude $65^{\circ} \mathrm{E}$. The southern fault zone at Asarisum is of transcurrent type, involving a shift with considerable horizontal component. In the Salmah area, however, it would appear that the fault system is confined to the north bank, and there is a zone some 500 metres in width occupied by a fault mélange, in which purple conglomerates and shales, green shales, and blocks of limestone of possible Mesozoic age are sheared together to produce a wild irregular complex of rock types. This fault zone lies $2.5 \mathrm{~km}$. north of the dam site.

Dam Site

18.4 The dam site itself is located in a complex of paragneiss and ortho-gneiss. The para-gneiss is probably a metamorphosed greywacke, associated with which are minor bands of limestone now in the condition of white marble. Intrusive into the paragneiss are sills and veins of acid ortho-gneiss. The whole complex is steeply folded, and the dam site is located on the more highly inclined part of a monocline. There are minor faults associated with the folding, one fault being seen on the left abutment, and another, of thrust type, being exposed on the right side, about $300 \mathrm{~m}$. downstream from the probable dam axis.

18.5 The prevailing dip of the metamorphic rocks is $40^{\circ}-50^{\circ}$ towards the N.N.W. with a tendency for the dip to change downstream towards the north. The left abutment has rather massive ribs of para-gneiss, interrupted by a wedge-shaped fault. The right abutment is less pronounced and consists of three more attenuated ribs.

18.6 The distance between normal high-water marks is between 45 and 50 metres, and between the ribs on the two banks near river level 70-80 metres. Upstream of the actual dam site, slightly round the bend in the river, there are submerged serrated outcrops of rock which prove that in some parts of the river the gravels are of negligible thickness. No rock outcrops are seen below water at the dam alignment, and it is difficult to assess the thickness of gravels which would be encountered in excavating the dam foundations. 


\section{Plio-Pleistocene}

18.7 Upstream of the dam gorge there are conglomerates and silts of probably PlioPleistocene age which dip about $20^{\circ}$ northwards, and rest with strong unconformity upon the more steeply up-ended metamorphic rocks. These beds are not present actually in the Salmah gorge.

Recent Gravels

18.8 On the north side of the Salmah gorge, as also on the north side of the Pul-iSher Khaj gorge, there are thick recent gravels which occupy a former erosion channel of the Hari Rud. These gravels are somewhat morainic in character, and include large and small blocks of rocks derived from the Hari Rud basin, such as sneiss, schist, limestone, rhyolite, andesite, agglomerate, conglomerate. The matrix oonsists of sand, predominant silt, and a slight proportion of olay. At the actual dam alignment the contact between these gravels and the underlying metamorphic rocks is at an elevation of about $50 \mathrm{~m}$. above river level. Further north, away from the river, the bed-rock of metamorphics descends to a lower level, and gravels fill the former erosion channel of the river.

Permeability of the Right Bank

18.9 The presence of gravels on the right bank, which can be seen to extend upstream to the western edge of the Salmah basin, raises the question of their permeability, and the water-tightness of the reservoir. A small test pit was dug on the right bank, about $80 \mathrm{~m}$. above river level, which indicated that the finer matrix of these gravels has a considerable silt content, with a very minor proportion of clay. It appears probable, therefore, that the gravels will have a low permeability.

18.10 Even if there is some leakage from the reservoir into the gravels on the right bank, it is considered that the water will be confined to the Hari Rud Valley, being unable to escape to north and south below the water-sheds on account of the impervious nature of the metamorphic rocks and slates which comprise the two sides of the valley. Any mild leakage that might occur into the gravels would remain within the gravels and come out downstream as minor springs, which would merely feed the small tributaries of the river Hari Rud.

18.11 The situation is reminiscent of the Sautet and St. Pierre-Cognet reservoirs on the Drac river, Isere, France. On the right (north-east) sides of these reservoirs there is a meandering pre-glacial channel of the Drac river which later became filled with morainic and fluvio-glacial sediments. In places along the perimeter of the reservoirs this old channel lies partially below reservoir level, and there has been considerable leakage from the reservoirs into the channels. The leakage in the case of the Sautet reservoir was estimated to be $2.5 \mathrm{~m}^{3} / \mathrm{sec}$. in 1935 but by 1957 had dropped to $1.9 \mathrm{~m} 3 / \mathrm{sec}$. on account of natural silting. In the case of the St. PierreCognet reservoir, the leakage at full supply level is between 180-200 litres/sec. The greater part of the material are fluvio-glacial gravels, some of which have a slight cement of calcium carbonate, while others are uncemented. Beds of coarse sands also occur, while true morainic formations are rather scarce.

18.12 The writer has visited both of the French reservoirs and has the impression that the fluvio-glacial deposits of the old Drac river valley are more permeable than the boulder gravels of Salmah, for there is an appreciable content of silt in the Hari Rud deposits, while silt is not common in the material which fills the old Drao channel. Consequently, it is not thought that the permeability of the Hari Rud gravelg is high, and the permeability ooefficient would probably not exceed about $10^{-4} \mathrm{~cm}^{3} / \mathrm{cm}^{2} / \mathrm{second}$. 
18.13 The dam itself would be founded on metamorphic rocks, and no fear need be entertained that the stability of the dam would be endangered by seepage through the gravels which are present in an earlier river channel just to the north of the dam alignment.

Type of Dam

18.14 The site is suitable for the construction of a concrete gravity dam $45-50 \mathrm{~m}$. in height above river level. The diversion tunnel could be on either side, that on the left bank probably being shorter than one on the right. No natural spillway exists.

18.15 The rock which forms the two abutments of the dam is unsuitable as a source of aggrefate because of its highly bedded and flaggy nature. The gravels on the north bank would provide better material, but of a very heterogeneous nature.

18.16 If a natural spillway were present at the Salmah site, it is possible that the dam could have been constructed largely of the moraine-like gravels of the right bank, though a search would be required for material suitable for the impervious section. The absence of such a spillway, and the failure to find exposures of homogeneous impervious material, would indicate that a gravity concrete dam may be the most suitable.

\section{Stability of Tectonic Faults}

18.17 While the Salmah dam site is located entirely within metamorphic rocks, and is involved with only minor faults, there is no doubt that the east-west Hari Rud valley owes its existence to major faults. Moreover, the displacement of the stream pattern along the east-west fault which runs $3.75 \mathrm{Km}$. south of the Asarisum dam site, $110 \mathrm{Km}$. east of the Salmah gorge, points to the existence of some very young faulting in the region. Although some of these faults must indeed be young, it is not possible to indicate on present evidence that they are still active. Information from seismographs outside Afghanistan only goes back 60 years, but during this period it would appear that the central part of Afghanistan has been free from major shocks originatinci within the region. The effects of shocks arising in the perimeter seismic areas of Badakhshan, Baluchistan and Iran are not likely to be severe along the central Hari Rud. 
CHAPTER 19 - ASARISUM DAM SITE AND TASRA KAI DAM SITE

(Maps 13,14)

Introduction

\section{Date of Investigation}

19.1 A dam site on the Upper Hari Rud near Asarisum was suspected in October 1960 from a study of the air photographs. The site was first visited on 14.8 .61 in the oompany of A.E.Pallister, Topographical Engineer, and was considered to be suitable for the construction of a concrete dam.

19.2 The Hari Rud gorge at Tasra Kai, downstream of Badgah was first visited on 7.8.61, during the reconnaissance of sites on the Upper Hari Rud.

19.3 As a result of the reoonnaissanoe visit which was made in August 1961, the Topographioal Group consisting of Messrs. Pallister and Rijskijk made $1: 2,000$ ourveys of both the Asarisum and Tasra Kai dam sites during October-November 1961. The present author followed them in late October 1961. The Tasra Kai map was not completed, and it was not therefore possible to undertake detailed geological mapping of that site. A week was however spent at Asarisum in the company of Mr. Abdul Rauf, during OctoberNovember 1961, preparing a geological map on the exoellent topographical foundation. The weather was already becoming cold, and ioe was forming along the banks of the Hari Rud.

19.4 A Progress Report was written in 1961 regarding both sites, but other duties prevented a fuller report being prepared, and it was not until over two years later that it was possible to produce the present description of the two dam sites.

\section{Looation}

19.5 The new 1:100,000 topographical maps of the Upper Hari Rud were not available until the end of 1963, and topographical particulars were made by the U.N. Special Fund from field observations, with the assistance of the air photographs. Height was based on the Soviet bench mark 2175.6 metres $(7,138$ feet) located on the flood plain of the Hari Rud near Shotor Khan village $\left(34^{\circ} 28^{\prime}: 65^{\circ} 01^{1 / 2} 2^{\prime}\right)$.

19.6

Asarisum Dam Site

Tasra Kai Dam Site
Air Photographs

$46-\mathrm{B} .16880,16881$

48-20337
Map No. Coordinates

$$
411-D-4 \quad 34^{\circ} 281: 64^{\circ} 59^{\prime}
$$$$
412-C-2 \quad 34^{\circ} 32^{\prime}: 65^{\circ} 25^{\prime}
$$

Elevation

$2167 \mathrm{~m}$. $2301 \mathrm{~m}$.

19.7 The new Fairchild map 412-C-3 gives a height of $2139 \mathrm{~m}$. near Shotor Khan village ( $\left.34^{\circ} 28^{\prime}, 65^{\circ} 01^{\prime} 45^{\prime \prime}\right)$, at a location which must be at least 5 metres above the former :Soviet bench mark 2175.6. Consequently there appears to be an error of about 41 metres (135 feet) between the U.S.A. and Soviet levels. This discrepancy has only now been discovered in Rome on first perusal of the newly received maps, and has not yet been elucidated. As far as the present report is concerned, levels are related to the Soviet and not to the U.S.A. datum. 


\section{Climate}

19.8 The area lies under snow from about the second week of November until the end of May. At the time of the writer's visit in October-November, side streams were beginning to freeze up entirely and ice was forming along the banks of the Hari Rud. During the summer the day temperature may reach $38^{\circ} \mathrm{C}$, but the nights are cool.

19.9 It is probable that the motor trail between Kabul and Herat is only open to traffic for a period of five months between mid-June and mid-November.

\section{Regional Geology}

Available Information

19.10 The following information was available in connection with the geology of the upper Hari Rud:-

Preliminary geological map of Afghanistan scale 1:1,000,000. First prepared by H. Furrer of U.N.T.A.B., and revised by P. Hunger, U.N.T.A.B. This is a reconnaissance sketch map along routes in Afghanistan.

Ricognizioni Geologiche nell'Afghanistan. Ardito Desio. Boll.d.Soc.Geol.Italiana, Fasc.III (1960).

This account of traverses made by Professor Desio only concerns the area east of longitude $67^{\circ}$, which is $130 \mathrm{Km}$. east of Tasra Kai.

19.11 It was necessary to rely very largely on a photo-geological interpretation of the air photographs. Such an interpretation is rendered difficult by the extensive cover of Upper Tertiary sediments which rest, in an irregular manner, unconformably upon the older formations, and have an intricate boundary with them. The Upper Tertiaries are themselves gently tilted, in particular around the Tasra Kai and Asarisum domes.

19.12 There are difficulties in interpretation also in the case of the older rocks, and the peculiarities of lighting at the time when photograph 48-20337 was taken have obscured the lithological contrast which should have existed between granodiorite and overlying limestone in the area $2 \mathrm{Km}$. north-east of the Tasra Kai gorge. The intense black outcrop at coordinates $34^{\circ} 30^{\prime} \mathrm{N}: 64^{\circ} 59^{\prime} \mathrm{E}, 3.75 \mathrm{Km}$. north of the Asarisum dam site, which consists of basalt and dark green ash and agglomerate in the form of a volcanic plug, has the same photographic appearance as carbonaceous graphitio phyllite which occurs within the metamorphic rocks at coordinates $34^{\circ} 1^{\prime} 5^{\prime}$. $63^{\circ} 04.5^{\prime}$ in photograph $41-A-21644,3 \mathrm{Km}$. north-west of the Tangi Shah dam site.

19.13 Consequently, photo-geological interpretation is liable in this region to large errors except in those places where traverses and more detailed field work were possible. 


\section{Qeological Succession}

19.14 The following is a tentative geological succession for three areas along the upper Hari Rud between longitudes $65^{\circ}$ and $66^{\circ}$. It will be noted that along the Garmao chain of slightly metamorphosed inferred Palaezoic slates and phyllites, Upper Tertiaries rest direct on the metamorphics, without intervening volcanics and Cretaceous limestones. It is possible that already by the end of the Mesozoic, or early in the Tertiary, an east-west system of fractures developed along what is now the Hari Rud valley, accompanied by volcanic activity. Uplift on the south side probably resulted in removal of the Cretaceous marine deposits.

\begin{tabular}{|c|c|c|c|}
\hline$\frac{\text { Inferred Age }}{\text { Map No. }}$ & $\frac{\text { Asarisum Area }}{411-D-4}$ & $\frac{\text { Tasra Kai Area }}{412-C-2}$ & $\frac{\text { Carmao Area }}{\text { Not available }}$ \\
\hline Recent & $\begin{array}{l}\text { Valley-fill } \\
\text { alluvium }\end{array}$ & $\begin{array}{l}\text { Valley-fill } \\
\text { alluvium }\end{array}$ & \\
\hline Pleistocene & 4 gravel terraces & 3 gravel terraces & \\
\hline Upper Tertiary & Conglomerates, silts & $\begin{array}{l}\text { Conglomerates, silts } \\
\text { fresh-water limestone }\end{array}$ & $\begin{array}{l}\text { Conglomerates, } \\
\text { silts }\end{array}$ \\
\hline $\begin{array}{l}\text { Eocene- } \\
\text { Oligocene }\end{array}$ & $\begin{array}{l}\text { Andesite dykes. } \\
\text { Pillow-Basalt } \\
\text { intrusive. } \\
\text { Agglomerates }\end{array}$ & $\begin{array}{l}\text { Andesite dykes. } \\
\text { Basalt, Andesite, } \\
\text { Agglomerate, Tuff }\end{array}$ & Absent \\
\hline Cretaceous & $\begin{array}{l}\text { Cherty limestone } \\
\text { with bands of shale. } \\
\text { Massive Limestone }\end{array}$ & $\begin{array}{l}\text { Shale } \\
\text { Massive Limestone }\end{array}$ & Absent \\
\hline ? Nesozoic & $\begin{array}{l}\text { Carbonaceous slates, } \\
\text { bleaching to grey- } \\
\text { white colour. } \\
\text { To north and north- } \\
\text { east of Asarisum: } \\
\text { area of Flysch, con- } \\
\text { sisting of calc.silts, } \\
\text { silty limestones and } \\
\text { calc.sandstones }\end{array}$ & $\begin{array}{l}\text { Sedimentary contact } \\
\text { on eroded surfaces. } \\
\text { Granodiorite Complex }\end{array}$ & Absent \\
\hline ? Palaeozoic & & & $\begin{array}{l}\text { Dark slates, } \\
\text { Phyllites and } \\
\text { Quartzites }\end{array}$ \\
\hline
\end{tabular}

\section{Faulting}

19.15 The Hari Rud valley has been eroded along a major east-west fault zone. Particularly at Asarisum, there is clear faulting on both sides of the valley. The straight almost east-west ridge which is $6 \mathrm{Km}$. due north of the dam site represents a fault scarp. A syncline of Flysch has been obliquely truncated and faulted against a zone of volcanics. The fault is evident for $15 \mathrm{Km}$. in the photographs. 
19.16 On the south side of the Hari Rud there is a system of ENE-WSW echelon faults, two of which, 9 and $12 \mathrm{Km}$. in length, are well displayed in map No.411-D-4, where

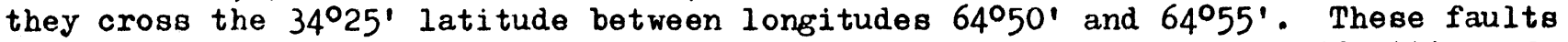
have a transcurrent component and are evidently responsible for the offsetting of the drainafe pattern by about $0.75 \mathrm{Km}$., the northern block having moved east relative to the southern blook. To determine the detailed nature of this fault zone would require much field work. Where it was inspected south of Asarisum the fault zone is about $0.5 \mathrm{Km}$. wide, and is demarcated by the presence of wedges of highly sheared limestone and brecciated slate, possibly of Mesozoic age, associated with Upper Tertiary sediments. Exanination failed to reveal any offsetting of recent talus cones, such as has occurred along the San Andreas fault system in California, and it is not possible to state whether the faults are still active. This zone of faulting is probably continuous with that which occurs along the north side of the Hari

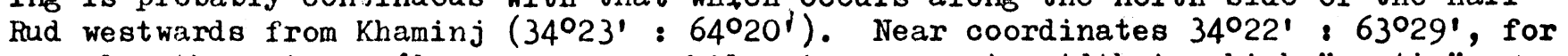
example, there is a mélange zone one kilometre or so in width in which "exotic" blocks of limestone occur within sheared shale and purple conglomerate. This mélange is obviously connected with the faulting, even though the mechanism of the tectonios is not understood. It is suggestive of transcurrent movements.

19.17 There is another group of east-west faults further south of Asarisum, near the conspicuous bend at the headwaters of the Kawgan (Kaoghan) river $\left(34^{\circ} 17^{\prime}:\right.$ : $^{\circ} 4^{\circ} 52^{\prime}$ ) which converges westwards towards the Hari fud in the Khaminj area.

19.18 The apparent extent of this system of faults is between longitudes $63^{\circ} 20^{\prime}$ and $65^{\circ}$, a distance of $160 \mathrm{Km}$., but the faults certainly extend both to the east and west, although largely almost obscured by Upper Tertiary deposits. For example, traces of the southern fault are indicated from the air photographs $6 \mathrm{Krn}$. S.S.W. of the Tasra Kai dam site, although for the most part the Upper Tertiaries conceal the fault pattern in the underlying early Tertiary and pre-Tertiary rocks. It would appear, therefore, that the recent movements which have resulted in displacement of the Upper Tertiary formations and stream patterns south of Asarisum are relatively local. Otherwise their influence on the Upper Tertiary rocks would have been more general and conspicuous in the air photographs.

\section{Asarisum Dam Site}

19.19 The Asarisum dam site is located on the conspicuous outcrop of dark rocks, seen in air photographs $46-\mathrm{B} / 16880$ \& 16881 , which covers approximately 38 ha. Similar isolated dark outcrops occur $4 \mathrm{Km}$. due north and $6 \mathrm{Km}$. north-west of Asarisum. The blanket of Upper Tertiary sediments conceals most of the relationships between the older rocks, but it is considered probable that each of the dark outcrops represents early Tertiary volcanic vents.

19.20 At Asarisum the volcanics are intrusive, with discordant contact, into carbonaceous slates. The volcanics have a faulted contact with the massive limestone on the north side, but it is thought that the faultins has taken place along the formerly intmaive contact with the limestones.

19.21 Wedges of slate are found within the volcanic rock on the right bank at the dam site, and in the NNW-SSE reach of the river, just upstream of the dam site. 


\section{Volcanic Rocks}

19.22 The volcanic rock is a pillow basalt, with balls and pillows up to two metres in diameter. The rock was at first regarded in places as a very coarse agglomerate, with blocks of lava embedded within volcanic ash. Agglomerate and dark green ash do in fact occur in the outcrop which is $4 \mathrm{Km}$. north of the dam site. In reality, however, the pillows of basalt at Asarisum are not surrounded by volcanic ash, but by softer more friable basalt, and the rock is not pyroclastio, but a gemuine pillow basalt. Unlike normal pillow lavas, which are extruded orer sub-marine slopes, this rock is definitely intrusive, and probably represents the intrusive magma which has solidified in a volcanic vent and must once have been a feeder to more truly extrusive basalt. The nearest equivalent of which the writer has seen published photographs is the pillow lava described by Bailey \& McCallien at Imrahor, $4 \mathrm{Km}$. south-east of Ankara in Turkey (Trans.Roy.Soc.Ed. 62, p.419, plate 1, 1951-53).

19.23 The basalt has abundant mimute amygdaloidal spherulites of calcite, quartz, serpentine and probably epidote. It is also out through by veins of quartz, caloite and micaceous haematite. Haematite is indeed the most characteristic product of mineralisation, although it does not occur in sufficient quantity to justify any attempt at commercial exploitation.

19.24 The softer basalt matrix between the hard pillows, the amygdales, and the mineralised veins, probably all represent different stages in hydro-thermal alteration during extrusion of the magma.

\section{Slates}

19.25 The slates in a weathered condition have a grey-white colour, but freshly exposed surfaces are almost black, and the rook is clearly carbonaceous. The pale weathering colour is due to bleaching.

19.26 Structural relationships in the slates are obscured by the intrusion of basalt. About 300 metres upstream of the dam site the slates are disposed in the form of a syncline, with axis aligned ENE-WSW, and pitch towards the ENE. The dominant divisional plane in the slates is not however the bedding, but represents a strong cleavage, which is orientated between ENE-WSW and NNE-SSW. The cleavage planes are sometimes vertical. Elsewhere they are inclined steeply towards the N.W.

19.27 On the right bank at the dam site the intrusive basalt outs right across the slaty cleavage, and the cleavage developed before intrusion of the basalt.

\section{Limestones}

19.28 The limestones do not come within the vicinity of the possible dam sites. They form the north-west side of the valley above elevations 2250-2280. m. On acoount of the topography of the reservoir, it is unlikely that any dam in the Asarisum gorge could exceed a height of $55 \mathrm{~m}$. up to elevation $2222 \mathrm{~m}$.

19.29 Some of the limestone is massive, but much is more thinly bedded and associated with calcareous slates. The limestone mass has developed a pronounced fracture cleavage which is aligned ENE-WSW, in the same manner as the true cleavage of the carbonaceous slates. The limestone is clearly strongly folded, although the fracture cleavage tends to obscure the true fold disposition. The dip is sometimes discernible on account of zones of chert nodules which occur parallel to the bedding planes. 


\section{Upper Tertiaries}

19.30 The Upper Tertiary formations consist of conglomerates, sandstones, and silts almost with a loess aspect. These formations oap the hill on the left bank of the river at the dam site, dropping westwards in elevation from 2255 to $2185 \mathrm{~m}$. in a distance of 560 metres, equivalent to a dip of $7^{\circ}$. Further south the Upper Tertiary rocks are much thicker, and they occupy a former valley which had been excavated by the Hari Rud during the middle Tertiary. This relationship is similar to that at the Darunter frorge of the Kabul river just upstream from Jalalabad, whioh is now the location of a dam under construction by Soviet engineers. In both cases, the present gorge of the river is cut through hard older rocks, while former channels are now occupied by Upper Tertiary formations.

19. 31 There is an area of conglomerates on the left bank by survey stations 3,4 and 8 , where the conglomerates may average $15 \mathrm{~m}$. in thickness, and cover about $45,000 \mathrm{~m}^{2}$. Out of the total volume within this area of about $675,000 \mathrm{~m}^{3}$, possibly $300,000 \mathrm{~m}^{3}$ may represent recoverable pebbles and cobbles for concrete aggregate in the event of a concrete dam being constructed. The material is very varied, consisting of basalts, andesites, limestones, slates, calc-sandstones, calc-shales, embedded within a matrix of partially calcified sandstone.

\section{Dykes}

19. 32 Dykes of fine-grained andesitic rock cut the pillow basalt, the slates and the limestones, but do not penetrate the Upper Tertiaries. One dyke, orientated N.E.S.W. runs obliquely up the right abutment of the upper dam site. The dykes appear to follow the general direction of cleavage in the slates and limestone, but must be long subsequent in time to the development of the cleavage.

\section{Faults}

19.33 In addition to the faults discussed in paragraphs 19.6 to 19.9 , there is considered to be a fault of sone magnitude along the former intrusive contact between the pillow basalt and the limestones. The limestones are cut by ENE-WSW faults, while one NW-SE fault cuts both limestone and basalt and reaches the Hari Rud just downstream of the toe of the upper dam site.

Location of Dam

19.34 The best location for a dam at Asarisum is considered to be between survey stations 5 and 18, with a N.W.-S.E. orientation of axis. The crest length up to $2230 \mathrm{~m}$. elevation on present topography, and without regard to the stripping which will be necessary in order to reach foundation grade, is 140 metres. The left abutment would be located entirely within pillow basalt. The upper part of the right abutment would lie against a wedge of carbonaceous slate which is $20 \mathrm{~m}$. wide in horizontal projection.

19. 35 One other possible location is $550 \mathrm{~m}$. downstream from the proposed alignment, and 1.2 metres lower in river-bed elevation. This alignment would be located entirely within basalt. Crest length before stripping would be about 190 metres.

19.36 It is considered that the pillow basalt would make a suitable foundation for a concrete lain. In spite of the appearance of the rock, it is not an agglomerate. The pillows of massive basalt are in any case impermeable, and have obvious strongth. The softer matrix of the more hydro-thernally altered basalt which forms envel pes 
to the pillows contains more hydro-thermal minerals than the enclosed pillows, and such minerals may be regarded as adding to the impermeability. As seen in a weathered condition, the matrix between the pillows lacks the strength of the pillows themselves, but it may be expected that fresh material is appreciably stronger. It should be stressed, however, that the pillows are essentially in contact with each other, in a manner resembling sand grains, while the matrix tends to develop in the interstices between the pillows. Thus, any stresses imposed by a dam would be taken up essentially by the pillows of basalt, whioh form about 95 percent of the volume of the rock.

Depth of River Gravels

19.37 Rocks are exposed in the river bed just $100 \mathrm{~m}$. upstream of the dam site. It is considered that the depth of gravels at'the suggested dam alignment is only a matter of a few metres.

Foundation Grade

19. 38 While it is almost certain that the depth of stripping required in the river bed will be small, on account of the shallow depth of the gravels, it is clear that considerable excavation will be necessary on the abutments in order to remove weathered basalt and slate, and in particular to reach fresh basaltic matrix between the pillows. Only drilling and tunnelling, will establish the extent to which such strippine will be necessary, but it is unlikely to be less than 5-10 metres on each abutment.

Tye of Dam

19.39 It may be accepted that the Hari Rud gorge at Asarisum is suitable for the construction of a concrete dam. Assregate is available in the Upper Tertiary comglonerates, although it is beterogeneous in character, and has a considerable component of volcanic rocks. The haulage of cement to a dam located at Asarisum would, however, be costly, for the site is about $508 \mathrm{Km}$. from Kabul and $580 \mathrm{Km}$. from Jabal Saraj. It might be easier to import cement from the U.S.S.R. via Kushka and Herat, but even so, the haulage from railhead would be not less than $500 \mathrm{Km}$.

19.40 There is abundant rock material for a rock-fill dam. The limestones on the north bank would probably be more suitable than the conglomerates on the south bank, and a cravity feed from a limestone quarry situated directly above the dam site would be easy. There is a deficiency in suitable material for an impervious core, since the Upper Tertiary silts probably lack shear strength. A concrete slab may be necessary if a rock-fill structure were built.

19.41 No suitable spillway exists at the dam site, and the gap in the south bank ridge could never be used as a spillway because of the presence of easily eroded silts.

\section{Limiting Height for Dam}

19.42 The critical factor, which limits the height of a dam in the Asarisum gorge, is the gap in the north-south ridge which is $1.6 \mathrm{Km}$. south of the upper dam site, a and $250 \mathrm{~m}$. east of the acute-angle bend in the Hari Rud that is $2 \mathrm{Km}$. downstream of the dam site. This ridge is part of the left perimeter of the reservoir. It is very narrow, and has been breached by the backward eastward erosion of a gully descending to the Hari Rud at the acute-angle bend. The gully has cut back through the cliffs of easily eroded conglomerates and silts belonging to the Upper Tertiaries. 
19.43 Unfortunately, the gap in the cliff is outside the area of the 1:2,000 topographical map prepared in September-October 1961, and its exact elevation is not known. It is thought, however, to be about 55-60 m. above the level of the Hari Rud.

19.44 This gap would support an earth dyke, but it should be stressed that the dyke would be based on silts and conglomerates which expose a vertical cliff face towards the west side. It must be accepted that the cohesion and shear strength of the loess-like silts is low. Consequently, if a dyke were to be constructed close to the cliff, in order to block the small erosion gap, the horizontal shear under the downstream part of the dam foundation could not be neutralised on account of the absence of any support at the edge of the cliff. Any dyke which might be constructed round the gully which has been eroded in the ridge would consequently have to be looated some distance away from the edge of the cliff, in order to obtain sufficient shear resistance in the silt foundations, and that would involve a much higher dyke.

19.45 Indeed, the whole of the ridge, with its exposed cliff on the west side, must be regarded as somewhat suspect, if the reservoir were to reach up to near the crest. Inasmuch as the materials comprising the ridge consist of silts and partially cemented conglomerates, there is probably not much fear of the ridge being too permeable, but large-scale survey work would be required, and a cross section must be obtained, before the ridge could be regarded as structurally safe near its crest to act as a perimeter to the reservoir.

\section{Alternative Dam Site}

$19.46 \mathrm{~A}$ bend in the Hari Rud which is $4.5 \mathrm{Km}$. west of Asarisum, and 7.25 river-Km. downstream from the site (grid coordinates 6784: 38154) has a narrow gorge eroded probably in volcanic rocks. There is a saddle within the loop of the bend, which is lower than the gorge itself and might act as a spillway.

19.47 A.E.Pallister has estimated that the saddle may be 50 metres in elevation above river level. Since the gradient of the Hari Rud at Asarisum was found by the topographical group of the U.N. Special Fund to be $3.9 \mathrm{~m} / \mathrm{Km}$., it follows that the level of the river at the bend which is $7.25 \mathrm{Km}$. downstream from Asarisum may be $28 \mathrm{~m}$. lower, or say at elevation 2139 (based on the U.S.S.R. bench mark at Shotor Khan). Since any dam at the lower bend would have to be almost $30 \mathrm{~m}$. higher than one at Asarisum in order to obtain equivalent storage, it follows that a dam at the lower bend presents no advantages on account of the limiting height of the low saddle.

19.48 More work will be required in this part of the Hari Rud than the group was able to undertake during its two short visits to this upland area. It would appear, however, that if the storage provided by a dam about $55 \mathrm{~m}$. in height at Asarisum is insufficient, it may be necessary to consider the Tasra Kai site which is described in the following section of this report.

\section{Tasra Kai Dam Site}

19.49 The topographical map of the Tasra Kai gorge was prepared between October and early November 1961, but it was not completed until it was too late to return to the area that year. Warning signs of impending winter snows occurred on November 7 th while the group was in camp at Tangi Azao, 120 air-Km. WSW of Tasra Kai, at an altitude of 2300 metres (7546 feet), and snow in fact began to fall on November 10th, two days after the group had left the highlands for Obeh and Herat. 
19.50 The geology is accordingly represented by a map based on the 12-inoh focallength photographs 48-20336 and 20336A, which in that partioular area have a scale of almost exactly $1: 25,000$, as cheoked from map 412-C-2 just now reoeived.

19.51 The possible dam sites are in the gorge of the Hari Fud between 1,000 and 1,500 metres downstream of the confluence of the Tasra Kai stream with the Hari Rud. River-bed elevations in this reach of the river were determined by the Topographical Group to lie between 2300.7 and 2301.8 metres above sea level, based on the Soviet bench mark near Shotor Khan village (paragraph above). The Hari Rud here has a gradient of $2.5 \mathrm{~m} / \mathrm{km}$.

\section{Geological Structure}

19.52 The dam sites are located in Cretaceous limestones and interbedded shales. Overlying the limestone is a group of shales which crop out on the east-west ridge forming the left bank, but do not descend to river level near the possible alignments. The limestones rest with sedimentary contact upon a granodiorite complex, and are invaded by volcanic intrusions. A fine-grained voloanic ash forms the hill in the southward olosing loop of the river. Basio dykes out the limestones in a WNW-ESE direction.

19.53 The whole complex occurs in the form of a partial dome, and is overlain unconformably by Upper Tertiary rocks, which consist of conglomerates, silts, and beds of marly fresh-water limestone. The conglomerates are strongly cemented with calcite. The Upper Tertiaries dip gently outward from the crest of the dome, dips being southwards along the Tasra Kai and westwards downstream of the main gorge.

19.54 The area is extensively faulted, the majority of fauts being aligned ENE-WSW, although there is another group with a direction NW-SE. The faults do not appear to out the Upper Tertiary formations and must therefore be regarded as early Tertiary in age, and static. The ENE-WSW faults have the same direction as those which olose to Asarisum have resulted in offsetting of the drainage pattern. It may be assumed therefore that rejuvenation of fault movement has occurred locally around Asarisum, but that in general the faults became inactive before the Upper Tertiary.

\section{Upper Alignment}

Approx. East-West: Crest Length at $+60 \mathrm{~m} .=135 \mathrm{~m}$.

19.55 The right abutment consists of a dip slope of dark cherty limestones, shaly limestones and calcareous shales. The dip is $25^{\circ}$ - $30^{\circ}$ in a $260^{\circ}$ direction, down the slope of the right bank. The left abutment is a steep scarp slope, with the dip awa into the hill away from the gorge.

19.56 In some formations, particularly in the case of alternations of porous permeable sandstones and clays, or with a marl succession, a down-slope dip such as exists on the right bank at Tasra Kai would be unstable and liable to slipping. In the case of these cretaceous limestones and calcareous shales, however, the different lithological units appear to have a high coefficient of friction which is likely to remain constant regardless of the presence or absence of water in the limestone joints. Consequently, it is considered that the right abutment is stable, and that landslips along the bedding planes should not occur. 
19.57 The left abutment is steep, being a cliff of limestone with underlying chloareous shales. There is a steep joint system which dips to the south-east, and there are two fault gullies, orientated N.W.-S.E., in both cases with a downthrow of about $30 \mathrm{~m}$. on the north-east side. The basio disposition is stable, but the fault gullies will certainly require further investigation.

19.58 The depth of the river-bed gravels should be very small.

Lower Alisnment

Approx. north-south: Crest Length at $+60 \mathrm{~m} \cdot=115 \mathrm{~m}$.

19.59 In this reach, the river has turned westwards, while the limestones and calcareous shales still retain their westerly dip of about $20^{\circ}$. Both banks therefore display a moderately gentle downstream dip.

19.60 The right abutment has alternations of limestone cliffs and more gentle alopes with scree.

19.61 The left abutment is almost vertical. It looks sounder from a distance than from close proximity along the river bed. When seen near at hand the two curved generally east-west gullies which come down to river edge at the bend give the impression of being shatter zones, and of having weakened the abutment. From a distance, however, this large limestone buttress looks reasonably sound.

19.62 There are not likely to be any river gravels along this alignment, and foundation grade should not be at a great depth below low water level.

\section{Discussion}

19.63 The limestone mass present in the northward closing loop that would form the left abutment at both alignments is broken by two NW-SE faults and two ENE-WSW faults. The limestone has some cavernous zones, but in general would appear to be free from karstic solution effects. This left abutment would certainly require much investifation by means of tunnels.

19.64 Of the two alignments, the lower one in the part of the gorge which runs approximately east-west, is probably the sounder in possessing a more symmetrical profile and in having downstream dips on both banks.

Type of Dam

19.65 There is little doubt that the gorge would take a concrete dam, but it is certain that much foundation treatment would be required on the left abutment.

19.66 In view of the distance of this site from Kabul and Herat (it is almost equidistant from both cities and in the heart of the Afghanistan highlands) the transport of cement in the case of a concrete dam being constructed would be very costly. Consequently, it would be more desirable to consider the design of a rock-fill structure, with an upstream concrete blanket.

19.67 The saddle on the left bank with elevation $2399.7 \mathrm{~m}$. or $99 \mathrm{~m}$. above the level of the river at the lower alignment, could be excavated as a spillway. The spillwaters through this saddle would not return to the Hari Rud until $2.5 \mathrm{Km}$. below the lower alignment, and there would be no danger of erosion of the downstream toe of the dam by back-eddies from floods passed by the spillway. 


\section{Reservoir Basin}

19.68 The reservoir basin upstream of the two alignments is principally composed of granodiorite complex. There are, however, outcrops of Cretaceous limestone on the right bank just downstream of Badgah village and on both banks in the Badgah/Tasra Kai gorge.

19.69 Along the south bank of the Badgah basin there are steeply dipping probably Cretaceous conglomerates together with chocolate coloured shales. Overlyins all the formations upon an irregular erosion surface are Tertiary cemented conglomerates and silts.

19.70 Aside from the Cretaceous limestone outcrops downstream of Badgah, tle formations forming the perimeter of the reservoir basin are impermeable. The limestones themselves are associated with variagated shales, and the sedimentary complex appears to be perched upon the granodiorite complex, and to have been invaded by post-Cretaceous volcanic rocks.

19.71 The structural disposition is certainly complicated, and it is difficult to determine a satisfactory three-dimensional structural pattern. But the basic disposition may be regarded as favourable in regard to permeability. The granodiorite forms a basement, while the voloanio injections, and steeply in-faulted shales (such as $2 \mathrm{Km}$. downstream of the lower alignment) would act as barriers to lateral groundwater migration.

\section{Conclusions}

19.72 It is clear that much more work will be required before a decision can be made regarding the best location for a dam on the Upper Hari Rud. Such work can only be undertaken during the limited period of five months between mid-June and mid-November.

19.73 The Asarisum dam site is located principally within pillow basalt and it is not thought that much foundation treatment will be required in this rock. Unfortunately, however, the ridge of soft Upper Tertiary sediments which forms the left perimeter of the reservoir $1.6 \mathrm{Km}$. south of the dam site is suspect in regard to stability, and forms a limiting factor in the heightof a dam at Asarisum. No suitable spillway exists.

19.74 Foundation treatment of the limestones at Tasra Kai will be heavy, as there are many weak zones in the left abutment. This site possesses a saddle, $99 \mathrm{~m}$. in elevation above river level, which could be excavated into a spillway.

19.75 Both sides are remote from cement factories and it is probable that a rockfill struoture would be the most economical. Neither site possesses very suitable impervious core material, as the Upper Tertiary silts lack shear strength. 
CHAPTER 20 - GEOLOG ICAL REPOHT ON THE: TANG-I-SHAH

DAY SITE, KAWGAN RIVER

(Maps 15,16)

1. Introduction

20.1 The Tang-i-Shah dam site was first located from the Fairchild air photographs and was discussed in a report dated 3rd Dctober 1961. An estimate from the air photorraphs guggested that the gorge might be 20 metres wide at the bottom, with sides that sloped between $60^{\circ}$ and $70^{\circ}$ from the horizontal.

20.2 A reconnaissance visit was made to the gorge on November $15 \mathrm{th} / 16 \mathrm{th} 1961$ at the end of field work on dam sites in central Afghanistan. The basic geological features of the dam site were given in paragraphs 17-25 of a progress report dated 24th November, 1961. The gorge was found to be $26 \mathrm{~m}$. wide at its north-exit, and the sides slope at $70^{\circ}$ to $75^{\circ}$ from the horizontal. The site was considered to be feasible for the construction of a high dam, and it was recommended that a topoeraphical survey should be undertaken. It was realised that storage upstream of the canyon was not large, but it was thought that, with an assumed river gradient of $1: 333$, at dam $60 \mathrm{~m}$. in height might store about $200,000,000$ cubic metres of water.

20.3 In January 1962 the topographical group of the Special Fund team started a detailed survey of the dam site and reservoir basin. An excellent topographical map on the scale of $1: 2,500$, with contour intervals $10 \mathrm{~m}$., was carried out by Messrs. Pallister and Rijsdijk of an area of $2.85 \mathrm{~km}^{2}(1.1 \mathrm{sq} . \mathrm{miles})$. The river gradient was found to be $1: 200$, and the storage is unfortunately even less than had been anticipatied in November 1961.

20.4 On completion of the topographical map the present writer undertook a geological survey of the dam site between March 5th and 17th, 1962. He was accompanied by counterparts Mr. Abdul Rauf and Mr. Lal Mohanmad, who were most helpful in making camp and transport arrangements, and in sorting out the grade sizes of gravel from an exploratory pit. Work on the reservoir basin could not be undertaken on account of other commitments in the area, but it is hoped that the essential geological characteristics of the dam site and its vicinity have been determined.

\section{Location of Tang-i-Shah}

Approx coordinates

Elevation

Fairchild Air photographs

Soviet Air Photograph

Catchment Area

Nearest motorable village

Air distance of Tangi from Herat City

\author{
$34^{\circ} 10^{\prime}: 63^{\circ} 06^{\prime}$ \\ 1284 m. a.s.l. \\ $41 / 4017-4018$ \\ $41-\mathrm{A} / 21644-21645$ \\ 5513-58 of line 9 . \\ End of series, and no \\ stereoscopic pair available. \\ $7,000 \mathrm{Km}^{2}$ \\ Langar $\left(34^{\circ} 13^{\prime}: 62^{\circ} 59^{\prime}\right)$ \\ $85 \mathrm{Km}$. (53 miles) E.S.E. of \\ Herat City.
}




\section{Acoess Road}

20.5 With the completion of the Soviet Bridge over the Hari Rud south of Shahr-1Nau, Herat, the distance from the Ariana air office at Herat to Langar Village is $98 \mathrm{Km}$. ( $61 \mathrm{miles}$ ), based on the kilometre readings of a USSR Jeep and a Dodge Power Wagon. A Willys Jeep also used on one trip reads $7.3 \%$ in excess of the other vehicles.

20.6 The track from the Herat-Shindand concrete highway near Herat airfield to Langar village is at present $83.5 \mathrm{Km}$. (52 miles) but is liable to variation depending on diversions over sandy zones and canal-flooded reaches. The track runs mainly along the northern edge of coalescing outwash fans (Bajada) spreading from the range south of the Hari Rud with a cover in some parts of wind-blown sand. The fans have northward gradients of 1.20 to $1: 50$ and are subject to frequent and variable washouts from looal rain storms, but the construction of Irish Bridges should not be excessively costly. The heights of Herat airfield and Langar village are respeotively 970 and 1240-1280 m. a.s.1. The whole route is covered by Soviet air photographs $5457-5475$ of Line 8 and $5492-5511$ of Line 9.

20.7 The time taken to traverse the traok from the airfield to Langar is about 3 to 3.5 hours, the average speed being around $25 \mathrm{Km} . \mathrm{p} . \mathrm{h}$. (15.5 m.p.h.)

Langar to Safed Khara

20.8 The route from Langar to Safed Khara, the village situated $1.3 \mathrm{Km}$. north of the dam site, is about $11 \mathrm{Km}$. in length and involves three crossings of the Kawgan river. It must at present be done by foot or on horse back. Pack animals take 3 hours over the journey.

20.9 The river was low and clear on the outward journey of the group on 5.3.62, but had risen as a consequence of rains on 11.3 .62 while returning on 17.3.62. It was then too turbid to see bottom and may have been running 5-6 m/sec. (say 200 cuseos.)

20.10 No estimate has been received from the Hydrologist for annual and abnnmal floods. Normal annual floods may be guessed as around $200 \mathrm{~m} / \mathrm{sec}$. Based on Arghandab data major floods of the order of $1: 100$ years may approximate to $2,500 \mathrm{~m} / \mathrm{sec}$. (say 90,000 cusecs.). This figure is however virtually a guess.

20.11 An acoess road from Langar to Safed Khara and the dam site could only keep on the left bank of the Kaoghan river, upstream of Kawgan village, at great cost in culverts and retaining walls. It would probably be cheaper to construct one bridge over the river near Kawgan village and then to keep to the right bank as far as Safed Khare and the dam site. The route is covered by Soviet air photographs 55125513 of Line 9, and Fairchild air photographs 40-C/21704 and 41/4017.

\section{Geological Succession}

20.12 The area has not hitherto been mapped geologically, and the whole succession has yet to be tied to the results of an ultimate regional survey. Not a single fossil was found, except in cobbles in the inferred Neogene conglomerates and terrace gravels, and the age-differentiation of the formations is a matter of speculation.

20.13 An extensive blanket of Terrace Gravels at various elevations covers wide areas of the older rocks and renders photo-geological interpretation difficult and often misleading. Indeed, quite aside from the terrace gravels, photo-geological studies of much of the area of central and south-west Afghanistan can do little more 
than indicate the broad geological grain of the country. Topographically, however, the air photographs have been of erreat value in selection of dam sites for investigation, and elimination of sites such as Tagau Kaza where a cover of outwash gravels was anticipated.

Geological Succession

Tang-i-Shah Area

\begin{tabular}{|c|c|c|}
\hline Inferred Age & Formation & $\begin{array}{l}\text { Approximate } \\
\text { Thickness }\end{array}$ \\
\hline Recent & River Alluvium & \\
\hline Pleistocene & $\begin{array}{l}\text { Terrace Gravels grading into moraine- } \\
\text { like boulder till. Present in at } \\
\text { least } 4 \text { levels } \\
\text { Angular Unconformity }\end{array}$ & $\begin{array}{l}\text { Near dam site from } \\
\text { river level to top } \\
\text { of third terraoe:- } \\
50 \mathrm{~m} \text {. }\end{array}$ \\
\hline Neogene & $\begin{array}{l}\text { Conglomerates, flaggy sandstones, } \\
\text { gypsiferous clays } \\
\text { Angular Unconformity }\end{array}$ & $+200 \mathrm{~m}$. \\
\hline Cretaceous & $\begin{array}{l}\text { Massive unbedded limestone of the } \\
\text { Tang-i-Shah Eorge } \\
\text { Disharmonic Contact }\end{array}$ & $0-+140 \mathrm{~m}$. \\
\hline $\begin{array}{l}\text { Mesozoio or } \\
\text { Palaeozoic }\end{array}$ & $\begin{array}{l}\text { Green is purple shale-slate-phyllite, } \\
\text { quartzitic phyllite, phyllitic quartzite, } \\
\text { altered diabage, vein quartz. } \\
\text { Faulted Contact }\end{array}$ & $\begin{array}{l}\text { indeterminate: } \\
\text { probably not less } \\
\text { than } 300 \mathrm{~m} .\end{array}$ \\
\hline $\begin{array}{l}\text { Palaeozoic or } \\
\text { Pre-Cambrian }\end{array}$ & $\begin{array}{l}\text { Wetamorphic Group } \\
\text { Gneiss, amphibolite, marble, carbon- } \\
\text { aceous phyllite, schist, dolomitic } \\
\text { tillite, acid injections }\end{array}$ & $\begin{array}{l}\text { indeterminate: } \\
\text { folded Basement: } \\
\text { part of fundamental } \\
\text { crust. }\end{array}$ \\
\hline
\end{tabular}

\section{Litholorical Characteristics}

Terrace Gravels

20.14 The terrace gravels are generally unbedded, uncemented and unsorted, although occasional outcrops do occur in which there is both bedding and slight cementation by calcium carbonate.

20.15 On the right bank of the Tagao Guzak, which joins the Kawgan at Safed Khara village, there is a high-level terrace of large boulder material recalling glacial moraine. Here the boulders reach a volume of 1-2 cubic metres, and consist of fossiliferous limestone, Neogene conglomerate, granite, gneiss and marble. This 
material is very similar to that seen on both sides of the Herat-Kushka road about $5 \mathrm{Km}$. from the entrance to the hill section along the new Soviet route near coordinates 34\%25' : 62011'. In the exposures north of Herat the blocks of Metamorphios reach a volume of as much as 40 cubic metres, but the material is totally ungraded, and there is every gradation from large blocks to rock flour.

20.16 In general, however, in the vicinity of the dam site, the terrace gravels have more the appearance of river gravels and not of glacial till. A pit was dug in the middle of $1305 \mathrm{~m}$. terrace 800 metres N.N.E. from survey station $\mathrm{R}-1$, and the larger pebbles and cobbles, exceeding about $5 \mathrm{~cm}$. in mean diameter, were separated by hand into size groups, no screens being available. In the table below is given an approximate evaluation of the material as a potential souroe of conorete aggregate. From this single pit it would appear that there is a considerable proportion of slaty and flaggy material which would be unsuitable as aggregate.

20.17 It should be stressed however that the terrace gravels are very variable in composition, and that a single pit cannot be regarded as representative.

20.18 The greater part of the terrace gravels, being uncemented, would respond easily to mechanical excavators.

Lithological Classifioation of Pebbles and Cobbles

form 0.5 cubic metre pit of terrace gravels

Mean diameter

Number of pebbles

etc.

Lithological

Types in percent

Quartzite andstone some flaggy

Slaty quartzite

Quartzitic slate

Slate

Limestone

Granite + Netamorphic

BasaltAndesite
$5-10 \mathrm{~cm}$

578
$15 \%$

$\begin{array}{ll}6 & 40 \\ 8.5 & 20\end{array}$

$\begin{array}{ll}6 & 40 \\ 8.5 & 20\end{array}$

$\begin{array}{ll}36 & 40 \\ 8.5 & 20\end{array}$

3

14

30

25

$15-20 \mathrm{~cm}$

50

20

$+20 \mathrm{~cm}$

80

0 
20.20 The conglomerates occur in beds averaging 3-4 metres in thickness and oonsist mainly of pebbles and cobbles of dav limestone, ranging in size from $2 \mathrm{~cm}$. to $15 \mathrm{~cm}$. There is a strong calcium-carbonate cement and the conglomerates have a ringing sound under the hammer.

20.21 The predominant limestone pebbles and cobbles, and relatively limited range in diameter, would provide excellent and more consistent material for concrete aggregate than the terrace gravels. Unfortunately, however, the calcite cement would necessitate blasting of the rock and crushing.

20.22 Moreover, the relative thinness of the conglomerate bands, and the greater proportion of interbedded clay, would involve a great deal of waste material if it were decided to quarry the conglomerates for aggregate.

\section{Dam Limestone}

20.23 The limestone flanking the gorge, and forming the serrated hills to the N.W., west, S.W. and east of the gorge, is massive and lacks visible bedding. It is typically pale grey in colour, although darker varieties do exist.

20.24 The linestone as exposed on the dome crest on either side of the gorge is a cemented limestone breccia, in which angular fragments of grey limestone are enclosed in a matrix of pale to dark-grey limestone. It is often only by close inspection that the composite nature of the material becomes manifest, for it normally looks homogeneous.

20.25 The breccia is almost without question not of tectonic origin, and may have arisen as a result of partial solution and re-cementation of the rock when the limestone had ceased to be under the sea and was subject to variable ground-water-table conditions prior to deposition of the Neogene formations.

20.26 The lack of bedding in a mass of limestone which, where fully developed and not succumbed to pre-lNeogene erosion, cannot be less than $140 \mathrm{~m}$. in thickness, is surprising. No fossils have been found, and it is difficult therefore to suppose that the limestone was originally a reef accumulation. It must have been formed from a calcite paste in which no organisms were present.

Green \& Purole Slates

20.27 This Eroup of variegated green and purple slates forms an extensive outcrop on the southern part of the map, and along the east side of the Kulao valley about $1 \mathrm{Km}$. west of the gorge.

20.28 The following rock types are present in the group:-

Shale, slate, phyllite

Quartzitic phyllite

Phyllitic quartzite

Lenticular beds of dark quartzite or greywacke

outcrops of bedded darkish limestone, with steep and erratic dips, occur just north and west of Tang-i-Shah village, infolded within, and probably part of, the slate succession. These limestones are separately indicated on the $1: 2,500$ map, from the Massive Limestone. 
intrusive diabase of dark greenish oolour representing altered dolerite intrusions.

veins and irregular bodies of quartz.

20.29 The group forms the foundation of the dam limestone and may be regarded as impermeable. Any ground-water percolating through the massive limestone must be held by the slates, and diverted along the interface between limestone and slates. The slates will thus be barriers against downward percolation of water, and against lateral migration in cases where the contact of limestone and slates is inclined.

\section{Metamorphics}

20.30 The Metamorphics do not directly concern this report since they crop out some distance to the west, and north-west of the dam site. The nearest outcrops are around Kulao, $1.25 \mathrm{Km}$. WSW of Safed Khara and probably in the hills on the left bank of the Kawgan just WSW of Tane-i-Shah village.

20. 31 There is a very varied assemblace of rocks in this group, including:- amphibolite, quartzite, phyllite, and schist, interbanded re-crystallised psammitepelite, pale marbles, and acid injection material. In addition, two interesting types are present between 2 and $2.5 \mathrm{Km}$. north-west of Safed Khara:- a brecciated carbonaceous phyllite with smears of graphitic material and a dolomitic rock with soattered ungraded inclusions suggestive of a metamorphosed calcareous tillite. This assooiation is reminiscent of the Blaini and Infra Krol stages of the SimlaMussoorie Hills in India, except for the greater degree of metamorphism in the case of the Kawgan formations.

20. 32 The Metamorphics may be regarded as impermeable. The abundance of phyllite and schist, and the high and variable dips, indicate that there are lithological and structural barriers throughout the outcrops of this group.

\section{Rerional Structure}

20.33 Between Langar and Safed Khara there are two zones of Metamorphics, with an intervening narrow zone of Neocene sediments by Kawgan village. At Safed Khara there is a second zone of Neogene sediments, which possibly joins up with the Kawgan outcrop, but the junction, if it occurs, is concealed by the Terrace Gravels of the right bank of the Tagao Guzak.

20. 34 The vicinity of the dam site comprises a foundation of green and purple slates upon which rests the massive unbedded limestones of the Tangi itself. The outcrop of the limestone is shaped like a foot, flanked on both sides by green and yurple slates, and these in turn are partially enclosed, except towards the north and northeast, by Metamorphics. Essentially the limestone has been folded into an unsymmetrical basin within which are smaller-magnitude corrugations in the form of secondary synclines and the gorge dome.

20.35 It is inferred that the underlying green and purple slates are broadly folded in accordance with the visible apparent pattern of the limestone, but the actual contact of the two formations where seen, for example 580 inetres N.N.F. of Tang-iShah village, shows a tectonic discordance. It is assumed that this discordance is due to the disharmonic manner of folding of the rigid limestone and more mobile slates to the same stresses in post-Cretaceous and post-Neogene times. 
20. 36 The complex of limest one and underlying slates was folded and was then eroded in several areas on the north side of the synoline during what is assumed to be the Paleogene. It was subsequently covered by Neogene sediments, with a strong unconformity on the north side. A striking exposure of this unconformity is seen at the north-west corner of the map 1:2,500 map, 750 metres north-west of survey station L-1, where green and purple slates dipping S.S.W., and overlying limestone, are overlapped by Neogene conglomerates dipping E.S.E. On the right bank of the Tagao Guzak, near Safed Khara village, Neogene conglomerates rest partly on two thin residual masses of massive limestone, and partly on the green and purple slates.

20.37 The complex, by now of slates, limestone and Neogene, was then refolded in the form of an unsymmetrioal syncline, with $30^{\circ} \mathrm{N}$. W. dips on the east side and $65^{\circ}$ east dips on the west side near Safed Khara village. Erosion followed, and there is now an unconformit; of Terrace Gravels across Neogene, limestone, slates and Metamorphics.

20.38 The contact between the slates and the Metamorphics runs NNE-SSW along the Kulao valley about $1 \mathrm{Km}$. west of the dam gorge, and crosses the Kawgan river downstream of Safed Khara village. This contact is now with strong probability in part a faulted one, but the fault where present will have followed along the old interface between slates and the original basement floor of Metamorphios. In the Kulao nala the Metamorphios strike orthogonally against the contact with the slates.

20. 39 Just downstream of Kawgan village, and extending to Dasht-i-Bala ( $34^{\circ} 11^{\prime}$, $62^{\circ} 581^{\prime}$ ), is a long narrow outorop of Neogene sediments with steep to vertical dips which is probably thrust-faulted against the Metamorphios on the southern side. These Neogene conglomerates, sandstones and shales are mainly chocolate-coloured, and might be thought to be a distinct group from the brown-coloured Neogene of Safed Khara village and the dam area. The writer has observed, however, north-west of Tang-i-Azao (about 100 air-kilometres east of Safed Khara) a very rapid and striking colour-change in a single major outcrop of Neogene sediments, and it is almost certain that the Kawgan and Safed Khara outcrops are of the same formation which has for an unexplained reason taken on different colours.

\section{Age of Faulting}

20.40 Actual fault contacts are difficult to observe. The obscure but vertical contact between the Metamorphics and slates is capped on both banks of the Kawgan river by Terrace Gravels, and the gravels have not suffered any faulting. Movement, along this fault must have stopped before the deposition of the gravels, which are of inferred Pleistocene age.

20.41 About $10 \mathrm{Km}$. north of Herat City (near coordinates 34\%26':62011'), and again $2.5 \mathrm{Km}$. north of Pastan village (near 34023':620261), a large-boulder conglomerate resembling moraine appears to be part of the folded Neogene group. The folded boulder conglomerate north of Herat is overlain by more distinctly moraine-like material which lacks folding. It appears to the writer that the peculiar and anomalously folded large-boulder conglomerates may represent either the earliest glaciation, or land-slip material, of the Pleistocene coincident with the final phases of earth movement, whereas the normal Terrace Gravels and more conspicuously morainic formation are unfolded and therefore subsequent to the last period of earth movement. These movements are certainly very young but are not, it is suggested, "Recent". 
20.42 At a distanoe of 170 air-kilometres E.N.E. of Tang-i-Shah, near the Amrutak dam site $\left(34^{\circ} 28^{\prime}, 64^{\circ} 59^{\prime}\right)$ the air photographs show displaced drainage patterns whioh oertainly ouggest very young. tear-faulting. It was not possible to establish, In the field, however, that the movements are so young as aotually to displaoe modern outirash fans and terrao gravels in the manner well known from the San Andreas and Haywards faults of California.

20.43 Consequently, while it must be allowed that there has been young folding and faulting in different areas along the Hari Rud valley, the evidence for the exietence of recent active seismic faults in this area is lacking.

\section{Looal Structure}

20.44 Due to the lack of interior bedding in the massive limestone, it is difficult to determine the local structure with absolute certainty. However, the outcrops of the underlying green and purple slates, and of the overlying Neogene sediments, provide a key to the disposition of the limestone, and it would appear that the configuration of the surface of the massive limestone corresponds fairly convinoingly with the geometry of the folding.

20.45 The main north-south part of the gorge is regarded as a dome in massive monolithio limestone, and it is concluded that the river, which has cut such a dramatio gorge with abutments that are $70^{\circ}$ to $75^{\circ}$ from the horizontal to a depth of $120 \mathrm{~m}$. ( 394 feet), and $138 / 151 \mathrm{~m}$. below survey stations $\mathrm{R}-1$ and $\mathrm{L}-1$, must be moderately close at its present level to the inferred arched substratum of green and purple slates.

20.46 The northern exit of the gorge ia thought to be a northern dip-slope, with a cover of Neogene sediments on either flank. Where the gorge at its upper end swings from north-south to N.W.-S.E. It is considered that a synclinal axis runs east-west, with a thin cover of Neogene on the left bank along the axis. The southern entry to the gorge shows north-dipping limestones resting on green and purple slates.

Slumped Zone

20.47 There is a very extensive zone of slumped limestone along the southern part of the map. This slumping is a consequence of gravitational sliding and settlement of the limestone over the green and purple slates along the southern scarp face. It is not an indication of any inherent weakness in the limestone, but is an example of the inevitable result of the superposition of a formation (however strong) that is exposed by erosion to the action of gravity over a foundation of shales, slates or schists which have low coefficients of friction. Between the area of slumped limestone and the north-south gorge there is a synclinal axis, with green and purple slates depressed well below the level of the river, and the influence of gravitatlonal sliding. Consequently, no significant northward advance of the slumped zone towards the north-south gorge can be envisaged in foreseeable time.

Open and Closed Joints

$20.48 \mathrm{As}$ a result of the slumping of the limestone over its shale/slate foundation, the massive limestone at its southern end is subject to open joints more or less parallel to the vertical scarp face. Further north, away from the influence of the slumping scarp face, the joints become tight. There are occasional cavities along the joints in the main north-south gorge, such as near station $6-3$ in an $80^{\circ}-260^{\circ}$ joint, and a slight water seep was noticed on the left bank from a $36^{\circ}-216^{\circ}$ joint which crosses the gorge near station G-2. But in general the joints are non- 
cavernous and tight, and the massive limestone has an altogether more compact, unbroken and robust aspect than the conspicuously bedded and jointed Cretaceous limestone which forms the foundation to the Kajakai dam near Kandahar.

No Faulting in N. - S. Gorge

20.49 It will naturally be asked if the straight and deep north-south gorge, which would be the location of any high dam on this river, has followed a major fault or shear zone. If any extensive fault or shear zone existed, its southern extrapolation should certainly be observable on the left bank where the gorge changes direction from north-south to N.W.-S.E. Yet, at this bend in the river, the limestone is singularly nassive, free from fault features, and possessing tight joints. It is concluded, therefore, that the north-south gorge has not followed a fault plane or zone of weakness of any important lateral extent.

Faults on the Right Bank

20.50 On the other hand, the limestone dome on the right (east) bank has been cut by two faults. A minor north-south fault with downthrow to the east is seen at the downstream end of the Tangi bringing Neogene sediments against limestone. A muoh more important fault runs N.N.E.-S.S.W. through the $1387.6 \mathrm{~m}$. saddle between stations $\mathrm{R}-1$ (1421.7) and $\mathrm{R}-4(1454.5)$, and enters the gorge in its N.W.-S.E. part 750 metres N.N.W. of Tang-i-Shah villace. This fault also has a downthrow to the east, and brings W.N.W. dipping Neogene sediments against a fault face of limestone just below survey station $\mathrm{R}-14(1396 \mathrm{~m}$.). On the east side of this fault there is an inlier of green and purple slates, together with intrusive diabase, and it is evident that in this local east of the fault there must have been much reduction of the limestone by erosion during the early Tertiary.

20.51 Neither of the faults mentioned in paragraph 20.50 above affects the stability of the dam. However, if the 1387.6 saddle were to be used as a spillway, some exploration would be necessary for the spillway foundations. Since the fault has brought slates in juxtaposition with limestone, there is not likely to be much leakage at the contact.

\section{Seismic Hazard}

20.52 It has already been suggested in paragraphs 20.40 to 20.43 that, although some of the faulting and folding is unquestionably young, there is no evidence in this region of the existence of actual active seismic faults.

20.53 In Herat City are the 5 striking minars associated with the mediaeval Massala, some of them now leaning westwards. They appear in imminent danger of collapsing and yet have stood intact for several centuries aside from crumbling of the superstructure and exfoliation of the glazed surface tiles. As mentioned in Chapter 5, paragraph 5.21, the writer has been informed by Tkacher that the minars of mosques in Ashkhabad have withstood near shocks of large magnitude, and it is evident that deductions in regard to absence of shocks near to Herat, which are based on the survival of minars, should not be pressed too far.

20.54 The area is in fact remote from the clusters of instrumentally-located epicentres which are prevalent near Ashkhabad, in Badakhshan (north-east Afghanistan), and around the Quetta re-entrant in Baluchistan, and is distant also from the more dispersed epicentres of Iran and the Makran coast. It is true that accurate determination of earthquake epicentres and magnitudes goes back only some 60 years, 
which is a short period in relation to the geological time scale, but it is reasonable on present evidence to assume that western and central Afghanistan forms part of an inverted triangle between Iran, Baluchistan and Badakhshan which is immune from major indigenous shocks, even though it may feel the fringe effects of large shallow-focus shocks originating in the neighbouring countries.

20.55 It is suggested, therefore, that a factor of $0.10 \mathrm{~g}$ should be sufficient in the design of a dam at Tang-i-Shah.

\section{Location of Dam Axis}

20.56 If, on account of the lack of any large storage basin upstream of Tang-i-Shah, a high dam of $120 \mathrm{~m}$. (394 feet) is necessary to provide the required 200,000,000 cubic metres of water, then only a very limited zone in the north-south gorge is possible on either side of a line joining survey stations R-1 and L-1. The limestone walls of the north-south gorge are massive and apparently monolithic. There is a N.E.-S.W. major joint, dipping steeply to the south-east (para. 20.48) along which a minor water seep was observed on the left bank. In addition, a large curved joint rises from river level to below station L-1 which may be related to the arching of the limestone dome.

20.57 At river level on the left bank there is a low elongated mass of limestone which appears to be separated from the main cliff. This mass will require investigation since the manner of its connection with the main wall of limestone is obscure.

20.58 The depth of river gravels in the gorge is unknown, but is thought to be less than 5 metres. However, a boring programme will be essential in order to determine gravel depth and excavation grade.

$20.59 \mathrm{As}$ indicated in paragraph 20.45, it is concluded that the green and purple slates which underlie the massive limestone should be at a shallow depth below river level in the core of the limestone dome. Those slates are indeed found alone the N.N.E.-S.S.W. fault at an elevation of $1360 \mathrm{~m}$. at a distance of $50-80 \mathrm{~m}$. E.N.E. of station R-14. They are only some 330-360 m. E.N.E. of the likely location of the dam axis. The downthrow of this fault is on the east side, and the fault would be expected to have depressed the slates on the east side relative to those which are on the west side in the area of the dam axis. Yet the exposed slates are not less than 80 metres higher in elevation on the east side of the fault than in the gorge itself. It is concluded that late-Cretaceous or early Palaeogene folding and erosion was responsible for original elevation of the slates on the east side of the gorge, and that post-Neogene faulting in the opposite sense must have partially reversed the formerly more accentuated height difference.

20.60 This anticipated proximity of the green and purple slates to the base of the dam will require a very careful drilling programme. It is conceivable that the base of the dam may actually descend to the level (now concealed) of the green and purple slates, and that the dam would thus be constructed on two formations, with slates at the base and limestone on the abutments. These two lithological fypes will have different moduli of elasticity. As it is probable that an arch-dam would be constructed in the gorge, much of the water load would be transferred to the massive limestone abutments by arch action, and the contrast in physical properties between the slates and the limestone may not be too serious. 
20.61 In the writer's opinion, the determination of the spatial relationship betwoen the massive limestone and its base of green and purple shales in the north-south gorge is the most crucial feature of the exploration. The exploration will require vertical and angle holes by means of diamond drills.

$20.62 \mathrm{~A}$ dam $120 \mathrm{~m}$. in height (from present river level) in the main gorge would neoessitate the construction of a subsidiary dam, perhaps as an emergency spillway, on the $1387.6 \mathrm{~m}$. saddle between stations $\mathrm{R}-1$ and $\mathrm{R}-4$, to a height of about $16 \mathrm{~m}$. above present saddle level. This subsidiary dam would be located across a fault, and would be founded on Neogene conglomerates, attenuated massive limestone, and green and purple slates. Exploration will be required on this saddle.

\section{Leakage}

Reservoir Basin

20.63 No exploration of the reservoir basin has yet been done, but the prevalence in the basin of Ketamorphics suggests that the reservoir should be tight. The prevailing strike of the Metamorphics in the lower part of the reservoir is N.E. - S.W. to E.N.E.-W.S.W., across the basin, and not north-south out of the basin, (Fairchild air photograph 41-A/21644). The extensive outcrops of rather featureless Metamorphics which are in the area covered by air photographs 41-A1/23245-23246 would not form a terrain liable to reservoir leakage.

Area of Dam

20.64 In paragraph 20.29 it was indicated that the green and purple slates would form an impermeable base to the massive limestone on which the dam would be mostly constructed. The question arises, however, about the possible migration of water, under full reservoir head, through the limestone and along the interface between the limestone and underlying slates. Could water that entered the limestone upstream of the dam under a head of 120 metres continue along the boundary surface between the limestone and slates so as to escape downstream?

20.65 The limestone is certainly jointed, in a rather complex manner, with east-west, N. E. -S.W. and N.W. -S.E. joints, but the majority of these in the area of the limestone, remote from the slumping scarp face, appear to be tight. Consequently, it is not thought that there would be serious migration of water through the joints. Some migration must be expected, however, under full reservoir head. This water would find its way partly in a northward direction around the limestone abutments, and partly along the base of the limestone where held by the underlying slates.

20.66 Escape of minor quantities of water through the apparently tight joints of the abutments would have to be controlled by a grout programme. Water moving along the boundary surface between the limestone and the underlying slates would be forced down the northern slopes of the dome and might come out where the dome changes over to a synoline, with southward dips. However, such a synclinal disposition in the limestone as may have existed at the beginning of the Palaeogene must have been largely eliminated by erosion before the unconformable deposition of the Neogene conglomerates, sandstones and shales. The contact of S.S.W. dipping slates with overlying limestone, and the overlap of both these formations by Neogene sediments, is well seen at the north-west corner of the 1:2,500 map, 750 metres N.N.W. of survey station $\mathrm{L}-1$, and a similar condition, but at a lower level and concealed by river terrace gravels, must exist under the bed of the river possibly 300 to 400 metres north of the dam site. 
20.67 Even if water were to move from the reservoir along the limestone slate interface, it would be held up north of the dam by the cover of Neogene conglomerates, sandstones and clays, which must abruptly truncate the inclined boundary surface between the two older formations. The Neogene conglomerates are strongly cemented with calcium carbonate and are impermeable. The sandstones would be permeable, but the predominant formation of the Neogene is gypsiferous clay, which is certainly an impermeable formation. Consequently, it is concluded that such leakage as might occur along the basal surface of the massive limestone would be prevented from final escape into the Kaweran valley by the undonformable cover of mainly impermeable Neogene sediments, which would act as a seal to water migrating through the preTertiary sediments.

20.68 The col which lies W.S.W. of Tang-i-Shah village, and separates the Kalao drainage from the Tang-i-Shah drainage, is not less than $1430 \mathrm{~m}$. in elevation. Green and purple slates form the greater part of the outcrop on both sides of the col, although there may be some limestone whioh is thought to belong to the slate formation. The col should be water-tight. This col might be considered as an alternative spillway to that of the $1387.6 \mathrm{~m}$. saddle which is 220 metres east of the dam location, and would require a tunnel.

\section{Raw Materials for Construction}

20.69 It is assumed that in a gorge of the type present at Tang-i-Shah any dam constructed would be of concrete. Consequently, it is necessary to look for coarse and fine aggregate, and possible raw materials for cement manufacture.

$20.70 \mathrm{As}$ discussed in paragraphs 20.14 to 20.22 , alternatives for supply of conorete aggregate exist in the uncemented terrace gravels and in the cemented Neogene conElomerates. The conglomerates have a more consistent supply of sound limestone cobbles, but would require blasting and crushing. Moreover, they are interbedded with clay and sandstone, which would involve the existence of much dead material. Of the pebbles, cobbles and boulders in the terrace gravels, only 50-70\% appeared to be suitable for aggregate in the case of the single pit sample studied. Further work would be required on these gravels.

20.71 An approximate estimate of volume of terrace gravels on the right bank, 550 to 950 metres north of the dam site, gives a figure of about 2,000,000 cubic metres. Other terrace gravels occur on the left bank at station L-4, 700 metres N.N.W. of station L-1, and about 500,000 cubic metres of gravel are available on the right bank of the Kawgan downstream of the confluence with the Tagao Guzak. As regards volume, there is no doubt that sufficient material is present in these terraces for the construction of a concrete dam. The problem is in regard to the physical suitability of the potential aggregate.

20.72 If the defects of the terrace gravels and Neogene conglomerates are considered to vitiate their use as conorete aggregate, the nearest material to the dam site would be the massive limestone itself. A suitable quarry site would be around the Pigeon Cave, 530 metres W.N.W. of survey station L-1 and the crushing plant could be in the flatter slopes below the cave. In spite of the brecciated nature of some of the limestone, the material is thoroughly cemented and consists only of carbonates. It is therefore a single component rock, with two lithological phases which are practically identical, and should react to crushing as if it were a normal unbrecciated limestone.

20.73 Clean sand has not been seen, but material washed from the terrace gravels might be suitable. 
20.74 In regard to cement, the only cement factory in Afghanistan is at Djebel-usSaraj, near Kabul, and the haulage distance would be about $1330 \mathrm{~km}$. or $830 \mathrm{miles}$, over an at present very rough track. The massive limestone of the Tangi has not yet been chemically analysed, and it is not known if $\mathrm{MgO}$ exceeds the normal limit for Portland Cement. Even if the limestone is chemically suitable for the manufacture of cement, there is no fuel in the neighbourhood other than some attenuated coal seams that are reported to occur about 90 air-kilometres E.N.E. of Herat and which are apparently not extensive enough for the coal to be marketed in Herat.

20.75 It is presumed, therefore, that cement for the construction of the dam would have to be imported from the U.S.S.R. in the same manner as the cement used in the concrete highway between Kushka, Herat and Shindand.

\section{Conclusions}

20.76 The Tang-i-Shah site would appear to be suitable for the construction of a thin-arch dam $120 \mathrm{~m}$. (394 feet) in height from present bed level, but this opinion is subject to the results obtained from the exploration recommended in the following paragraph.

20.77 Rigorous exploration by diamond drill holes will be required in the bed of the river to ascertain the disposition of the green and purple slates which should be present near the dam axis at shallow depth in the core of the limestone dome.

20.78 If an arch dam, or a cupola type of structure, were to be constructed in the gorge at Tang-i-Shah, the thrust under full reservoir load would be transferred mainly to the massive limestone abutments. Consequently, even if slates are proved by drilling to be present close to the base of the dam at a shallow depth under the bed of the river, this condition is not thought to be a very serious defect. This is a matter, however, which will require review by the engineers when the configuration of the slates under the river bed, and laterally into the two abutments at the lower levels, has been determined by diamond-drill exploration.

20.79 It is not considered that the north-south gorge has been carred out along any major fault, since no fault occurs on the left bank of the river where the gorge changes direction.

20.80 Active faults have not been found in the area, although there are many indications along the central and lower Hari Rud that some of the faulting and folding is relatively recent. Neither on geological grounds, nor in the light of seismographic evidence, nor on account of the state of preservation of the Massala minars in Herat, it is believed that the seismic hazard is great.

20.81 It is suggested that any ground-water migration that might occur through the base of the limestone above its boundary contact with the underlying slates would be stopped north of the dam on account of the unconformable truncation of both limestone and slates by impermeable facies in the Neogene.

20.82 Further work is required in order to select the most suitable aggregate material for concrete. The present choice is between the terrace gravels, crushed Neogene conglomerates and crushed massive limestone. 
CHAPTER 21 - GEOLOGICAL REPORT ON THE TANG I AZAO DAM SITE KAWGAN (KAOGHAN) RIVER

\section{Introduction}

21.1 The Tangi Azao gorge was visited on November 7 th and 8 th, 1961, after having first been located in September 1960 from the air photographs.

\section{Location}

\author{
21.2 Map Nos \\ Approx. coordinates: \\ Air Photographs \\ Elevation: \\ Road distances: \\ Catchment Area: \\ Discharge on $8.11 .61:$
}

Average annual runoff:

\author{
411-E-3 (not available in Rome) \\ $34^{\circ} 09^{\prime}: 64^{\circ} 11^{\prime}$ \\ $45 / 4243$ and $45-\mathrm{A} / 22736$ \\ $2250 \mathrm{~m}$. \\ Herat $237 \mathrm{Km}$. \\ Kabul $616 \mathrm{Km}$. \\ $2240 \mathrm{Km}^{2}$ \\ 900 litres/seo. (approx.) \\ This discharge must be related to \\ the freezing up of small springs \\ and streamlets which had started \\ at the onset of winter. \\ $200,000,000 \mathrm{~m}^{3}$ (estimate of Hydrologist)
}

21.3 Aside from a reconnaissance Progress Report prepared in November 1961, other duties have prevented this somewhat fuller note being written until over two years later.

\section{Nature of Reservoir Basin}

21.4 Topographically the Tangi Azao basin resembles that above the Asarisum dam site on the Hari Rud, and one would have expected similar storage. The capacity curve, computed from advance copies of maps 411-E-3+4 (which are not available in Rome) suggests however that the storage obtained from a dam $60 \mathrm{~m}$. in height would be only $59,000,000 \mathrm{~m}^{3}$. In order to obtain a storage of $200,000,000 \mathrm{~m}^{3}$, which is the average annual runoff, it would be necessary to construct a dam 80 metres in height. It is possible, however, that the contours of these maps are so placed in regard to the Tangi Azao basin that a slightly low capacity curve is obtained.

\section{Geological Succession}

21.5 The following is the geological succession in the area of the Tangi Azao dam site:-

Upper Tertiary

? Middle Tertiary
Conglomerates, sandstones, shales and fresh-water marly limestones Very variable colours

\section{Unconformity}

Dark chocolate-coloured conglomerates, sandstones, thin limestones, resembling the Murree Beds (Miocene) of West Pakistan and north-west India. Thickness possibly $1,000 \mathrm{~m}$. gently folded carapace, largely concealing older rocks

south side of grorge 


\section{Unconformity}

Cretaceous

Mesozolc or Palaezoic
Massive cream-white limestone

Probable Unconformity

Phyllites, grey slates, carbonaceous slates, with reins of quartz and calcite. Probably equivalent to slates below limestones at Tangi Shah, $100 \mathrm{Km}$. due west of Tangi Azao. the Tangi Azao gorge

north side of gorge

\section{Nature of Gorge}

21.6 The gorge is located in Cretaceous limestone, which has large gastropod, and possibly hippurite, fossils. The limestone is present in a band with steep southerly dip and east-west strike. It is underlain on the north side by phyllites and slates, and is overlain on the south side by a group of silicified sandstones and shales, followed by possibly Miocene conflomerates and sandstones. The limestone disappears to the east under a cover of Upper Tertiary conglomerates and marly limestones.

21.7 The limestone is massive and almost monolithio, with few visible bedding planes. On the east side of the gorge the slope is about $70^{\circ}$. On the west side it is about $50^{\circ}$. There is a large bollard on the left abutment, upstream of the anoient, possibly Pali, rock inscription, which may not be strictly in situ. Allowing for removal of this block, the bottom width of the Tangi is about $40 \mathrm{~m}$. The orest length at an elevation of 80 metres above river level, before stripping would be about 140 metres. The longitudinal length of the main section of the gorge is only about 110 metres, but downstream of this section there is a less narrow reach of about 100 metres with a considerable amount of boulder talus on the left bank.

21.8 There are virtually no gravels in the river bed, and the walls of the gorge, with the possible exception of the major buttress occupying the upstream half of the left abutment, consist of sound massive limestone. The buttress may prove by oxploration to have slipped from above. Aside from the possible necessity of removing this buttress, it is not considered that much excavation will be required on the abutments in order to reach foundations grade.

21.9 The limestone is not visibly karstic. It has a steep southward dip, and is underlain on the north, or downstream, side by impermeable phyllites and slates. There should be no danger of percolation losses out of the reservoir since the slaty rocks would act as a barrier on the downstream side. Exploration will be necessary to determine if the limestone itself lacks karstic solution effeots. The limestone is presumably in the form of a syncline, and must be underlain throughout by slates. Any loss of reservoir water into the limestone would therefore be retained therein, and would not leave the structural basin on which the reservoir would be founded. 


\section{Nature of Dam}

\section{Concrete Dam Feasible}

21.10 The gorge is certainly suitable for the construction of a concrete arch dam, but it is much less symmetrical than the Tangi Shah gorge which is cut by the same river $100 \mathrm{~km}$. due west of Tangi Azao.

21.11 The area is isolated. Although the present road distance of $237 \mathrm{Km}$. from Herat is not excessive, the road is extremely difficult between Tangi Azao and Pul-i-Sher Khaj, and transport of cement would be a problem. Assuming that an aroh dam at Tangi Azao might be $200,000 \mathrm{~m}^{3}$ in volume, and that the cement used would be $250 \mathrm{Kg} / \mathrm{m}^{3}$, the quantity of cement required for the dam itself would be 50,000 tons. This cement would have to be imported from the U.S.S.R., over a road distance of almost $400 \mathrm{Km}$. from railhead at Kushka.

21.12 The Upper Tertiary conglomerates would provide already rounded aggregate, but in cemented form which would require blasting. River-bed gravels are available $0.5 \mathrm{Km}$. upstream of the gorge.

\section{Rock-Fill Alternative}

21.13 The longitudinal length of the main section of the gorge between entrance and exit is only about 110 metres, although a wider and less satisfactory section exists downstream. If it were considered necessary to construct a dam 80 metres in height above river-bed level, any rock-fill struoture of that height is not likely to be less than 160-220 metres in base width. Such a dam would have therefore to extend downstream beyond the narrow section of the gorge.

21.14 No spillway exists at the dam site. The faulted gaps in the limestone ridges $6.5 \mathrm{Km}$. W.S.W. of Tangi Azao have not been visited, but are probably much higher than any dam likely to be constructed in the gorge.

21.15 The impermeable phylites and slates on the north side of the gorge could not be used as core-fill material since metamorphism has destroyed any plasticity that they may formerly have possessed. The Upper Tertiary silts probably lack shear strength and would not by themselves be suitable as impervious fill. It is probable that a concrete slab would be required on the upstream face of the dam. 
CHAPTER 22 - MARWA WEIR SITE : PASHDAN DAM SITE

Marwa Weir Site

22.1 The Marwa weir site is looated at coordinates $34^{\circ} 15^{\prime}$ : 62056'. River bed elevation is $1166 \mathrm{~m}$. , and in its narrow section just downstream of the confluence of the Hari Rud with the Kawgan, the floodplain gravels are only about $0.75 \mathrm{Km}$. wide. The rocky flanks of the valley are $12 \mathrm{Km}$. apart.

22.2 On the north side there is an outwash colluvial fan $5 \mathrm{Km}$. in width with an average gradient of $1: 23$. Rock does not occur until an elevation of 1480, or over $300 \mathrm{~m}$. above river level. North of Pushbar and the Cinar and Ganda springs, is an outcrop of granite, whioh closes westwards at longitude $62^{\circ} 52^{\prime}$, under a cover of metamorphic schists and gneisses. The two springs are possibly located along a fault line between the Metamorphics with granite intrusions, and poorly exposed red beds.

22.3 On the south side of the valley, Metamorphics are exposed in the bed of the Langar (34 $\left.{ }^{\circ} 13^{\prime}: 6^{\circ} 00^{\prime}\right)$ tributary, but they are overlain by up to $70 \mathrm{~m}$. of colluvium. South of the Metamorphics, near Dash-i-Bala village, there is a zone of Neogene sediments, but still further south is the main outcrop of Metamorphics, which extends south-eastwards to near the Tangi Shah dam site.

22.4 As a weir site no special geological studies are necessary. The construotion of weirs on river flood plain deposits is a technique which is already so well developed that geological opinion is unnecessary. It has however been suggested that a dam of 80 metres height might be constructed at the Marwa site, up to an elevation of $1246 \mathrm{~m}$. Such a dam would store much of the runoff of the combined Hari Rud and Kawgan rivers.

22.5 It should be stressed that the Marwa site is not suitable for the construction of even a rock-fill dam of $80 \mathrm{~m}$. height. Every possible alignment for such a dam would be based on colluvial outwash fans, river terraces, and the bed gravels. No rock is exposed throughout $12 \mathrm{Km}$. width of the valley, and a dam of $80 \mathrm{~m}$. height would be not less than $6 \mathrm{Km}$. in length, with unsatisfactory foundations.

Karrukh River: Pashdan Dam Site

22.6 The Karrukh dam site is located at the junction of 3 streams near coordinates $34^{\circ} 24^{\prime}$ : $62^{\circ} 25^{\prime}$, at an elevation of $1100 \mathrm{~m} ., 23 \mathrm{Km}$. E.N.E. of Herat. The catchment area is about $1,500 \mathrm{Km}^{2}$.

22.7 The site was first visited in 1950 by Tim de Jong during a winter snow storm. From pebbles which were shown to him, he concluded that the abutments consisted of metamorphic rooks.

22.8 The site is $450 \mathrm{~m}$. wide between the 1120 contours and both abutments consist of Neogene conglomerates, sandstones and shales dipping $35^{\circ}$ from the horizontal in a S.S.E. direction. The conglomerates have numerous cobbles of metamorphic rocks, which is the reason why Tim de Jong, in poor visibility, assumed that the abutments belonged to the Metamorphics. The river bed is occupied by coarse gravels. 
22.9 A rock-fill structure might be constructed here, but it should be noted that the bed gravels are coarse and permeable, and that a deep cut-off would almost certainly be necessary.

22.10 The upstream slope is about $1: 80$, and a 30 metre struoture would only flood back $2.4 \mathrm{~km}$. An immense amount of outwash detritus has been brought down by the Karrukh river, which has been deposited in a fan that has an area of about $110 \mathrm{Km}^{2}$. This points to a river which is highly charged with silt during flood periods, and to a short reservoir life.

22.11 It is consequently sugeested that the Karrukh site is not suitable for the construction of a storage reservoir. The site is wide. The bed gravels are permeable and probably deep. The gradient upstream is high. Finally, the rapid rate of silting would imply a short reservoir life. 
CHAPTER 23 - HARI RUD VALLLEY BELOW OBEH

23.1 The Hari frud valley expands below Obeh into two partial basins. The Herat basin has a leneth of about $90 \mathrm{~km}$. and maximum width $25 \mathrm{Km}$. The Ghurian basin measures $50 \times 20 \mathrm{~km}$. The basins are separated by the northward prolongation of a limestone outorop which points towards an east-west metamorphic inlier on the northern side. The Eeneral trend of the valley is WNW-ESE.

23.2 There are extensive colluvial outwash fans on both flanks of the valley, with gradients varyine between $1: 20$ and 1:60. The fans are covered in several places by wind-blown sand, one of the principal exposures being $17 \mathrm{Km}$. east of the Herat airstrip. The cclluvium, in extending towards the axis of the valley, probably interdigitates with alluvial terraces along the axis of the valley. These deposits obscure the ceolosical relationships, and there is no knowledge of the astual thiokness of alluvium within the two basins.

\section{Valley Flanks}

23.3 Metamorphic rocks occur on the north side of the valley in three outcrops, separated by two east-west gaps each $20 \mathrm{Km}$. in width. The gaps are occupied by Neogene and have probably arisen by kNE-WSW cross warping, oblique to the axi.s of the valley. Neozene crops out around these Metamorphic inliers. On Hill 861 $\left(34^{\circ} 27^{\prime}: 61^{\circ} 35^{\prime}\right)$ there is a section of Neogene clays, sandstones and conglomerates $200 \mathrm{~m}$. wide which dip $60^{\circ}$ towards the south, that is, below the valley. The Neogene is, however, largely obscured by its own eluvial detritus.

23.4 On the south side of the valley there are several ENE-WSW faults which strike towards the Herat basin. Near Ghurian there is a complex association of Flysch, sandstone, shale and limestone, which has evidently been folded or faulted down alone a NE-SW axis and filled with Neogene, in the gap leading over to the Dasht-iRandan.

\section{Valley Floor}

23.5 The concealed base of the Herat and Ghurian basins probably includes faulted and folded representatives of all the formations which are exposed on the flanks. For instance, the wedge-shaped western termination of the Obeh Metamorphics $40 \mathrm{Km}$. east of Herat represents the plunge of the basement under the pitching anticline of Neogene, and it may be expected that both Neogene and underlying Metamorphics continue below colluvium and alluvium towards Herat.

\section{Valley Deposits}

23.6 A good section of the alluvium may be seen in the cliffs bordering the Rud-iKarobagh, $10 \mathrm{Km}$. west of the Ariana air office in Herat. Within the 4 metres exposed are alternations of clay, sandy silt, current-bedded sand, and pebbly sand, the average thickness of the alternations being $40 \mathrm{~cm}$. In other sections the silts have the appearance of being loess, and intermingling must take place between the alluvial formations and wind-blown silts and sands.

23.7 In January 1962 it was noticed that there was much wastage of water irrigation west of Herat, and for a distance of about $5 \mathrm{~km}$. east of the Ful-i-Hashimi bridge there were considerable spreads of saline efflorescenses due to saturation of the 
ground and evaporation. No drainage canals exist to remove the exoess water, whiob just flows over the ground into stagnant pools and slowly infiltrates below.

23.8 In oontrast to the lower Farah valley (Chapter 16, para.8), cemented Pleistocene conglomerates have not been noticed in the Herat and Ghurian basins exoept for partially cemented gravels $12 \mathrm{Km}$. W.S.W. of Ghurian. Moreover, the alluvium of the Herat basin, at least in the area between the Hari Rud and Herat oity, and for some distance west of the city, is in a more dissected condition than around Farah. The absence of the cemented conglomerates, and the more dissected condition of the alluvium, point to better drainage conditions near Herat, even though looally, as mentioned in paragraph 7 above, excess water may lead to salinity.

23.9 The whole Ghurian basin oloses towards the north-west in the Shabash gap $\left(34^{\circ} 30^{\prime}\right.$ : $\left.61^{\circ} 22^{\prime}\right)$ which is cut through folded Neogene sediments. The gap is about $2 \mathrm{Km}$. wide, while the flood-plain gravels of the Hari Rud river average about $0.5 \mathrm{Km}$. in width. There is likely to be sub-surface flow of groundwater from the upper levels of the Ghurian and Herat basin alluvium through the gap towards Kohistan. Since, however, it is improbable that the river gravels which overlie Neogene in the Shabash gap are as deep as the alluvium of the two basins, it may be conoluded that the deeper levels of groundwater within the basins are unable to spill over the Neogene sill at Shabash.

\section{Exploration}

23.10 The groundwater conditions of the Herat and Ghurian basins have not been studied. Much detailed work will be necessary before the disposition of the groundwater horizons is known. The following investigations are recommended:-

(1) Large-scale mapping on a soale of $1: 10,000$, with contours at 1 metre intervals.

(2) About 5 deep exploratory drill holes, designed to descend to a depth of $200-300 \mathrm{~m}$.

(3) Numerous shallow drill holes to be taken to a depth of $50-100 \mathrm{~m}$.

(4) Refraction-seismic profiles along and across the basins in order to determine the configuration of the floor to the alluvial basin. This seismic work would bo calibrated with the deep drilling.

(5) Water-table observations. 
PART IV - ADRASKAND RUD AND KASH RUD

\section{CONTENTS}

$\begin{array}{llr}\text { Chapter 24 } & \text { ADRASKAND RUD } & 1-26 \\ & \begin{array}{l}\text { Introduction } \\ \text { Rud-1-Gaz (Northern Adraskand) } \\ \text { Adraskand South of Shindand }\end{array} & 2-21 \\ & & 22-26 \\ 25 & \text { KASH RUD : AIR RECONNAISSANCE } & 1-9\end{array}$




\section{Introduction}

24.1 Only two parts of the Adraskand river system were examined for dam sites and reservoir basins. In March 1961 a visit was made to the gorge which is $32 \mathrm{Km}$. south of Shindand, where there is a site which would take a concrete dam. In July 1963 an examination was made of the Rud-i-Gaz tributary of the Adraskand. Otherwise little geological work has been done on this river.

\section{Rud-i-Gaz (Northern Adraskand)}

\section{Location}

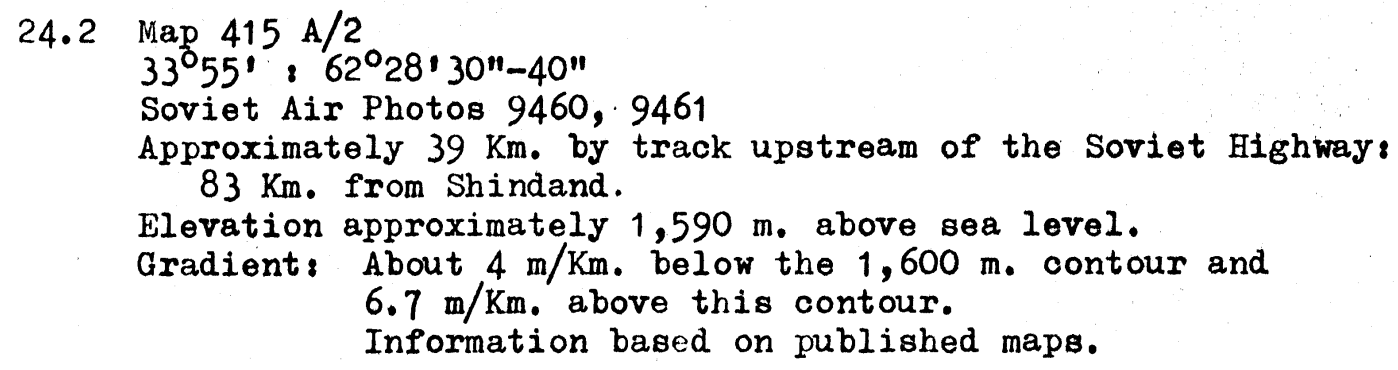

\section{Itinerary}

24.2 Abdul Rauf, and two Topographic counterparts, left Kabul on July 10th, 1963 with one Willys Jeep, two Gaz Jeeps and one Gaz truck. One vehicle went straight to Herat. The remainder made a route reconnaissance up the Rud-i-Gaz, turning off the main Soviet highway at coordinates $33^{\circ} 43^{\prime}: 62^{\circ} 17^{\prime}$ in $1: 50,000$ map $415 \mathrm{~A} / 4$, at a distance of $73 \mathrm{~km}$. from the Park Hotel, Herat, and $1 \mathrm{Km}$. north of the road bridge over the Rud-i-Gaz.

24. 3 A.E. Pallister and the writer reached Herat by air on July 14th 1963, and the whole party moved to the Rud-i-Gaz on July 15th, being able to take the transport upstream for a distance of $10.5 \mathrm{Km}$. On July $16 \mathrm{th}$ a march of $23 \mathrm{Km}$. was made in a temperature of $38^{\circ} \mathrm{C}$ to the Barghanak river settlement at $33^{\circ} 55^{\prime}: 62^{\circ} 26^{\prime}$. An inspection of two dam alignments on the Rud-i-Gaz about 4 air-kilometres east of Barehanak was made on July 17th, after which the party returned to Herat and continued up the Hari Rud for work at Salmah.

\section{Two Alignments}

24.4 Two alignments were studied, neither of which is very satisfactory. The upper site would take a dam $29 \mathrm{~m}$. in height above river level, while the lower site would accommodate a dam $36 \mathrm{~m}$. in height. Above these levels there are extensive highlevel river gravels.

24.5 The Rud-i-Gaz is deeply entrenched for $30 \mathrm{~m}$, and the valley only widens above this level. It is unfortunate that the $1,600 \mathrm{~m}$. contour on the 1:50,000 map does not correctly indicate the narrow nature of the valley below the $30 \mathrm{~m}$. elevation, and gives a somewhat deceptive impression of possible reservoir volumes. 
24.6 It is unlikely that the storage upstream of a $30 \mathrm{~m}$. dam in this gorge would exceed $15,000,000 \mathrm{~m}^{3}$.

\section{Geology}

24.7 The lower part of the Rud-i-Gaz muns through young Tertiary conglomerates and silts, which have a profound unconformity against the underlying voloanic rooks whioh are present upstream of Barghanak. The Barghanak gorge is out through voloanics and acid intrusive rocks, together with minor dykes of andesitic composition.

24.8 The two alignments east of Barghanak are located within rhyolites which dip at an angle of $60^{\circ}$ from the horizontal in a direction of $160-170^{\circ}$ or S.S.E. Downstream these rhyolites are associated with acid, almost granitic, rocks, which must extend upwards and form the greater part of hill 1892 on the left bank. They evidently formed the more slowly-cooled part of the acid magma in the voloanio terrain.

24.9 Cutting the rhyolites are dykes, usually less than one metre in width, of andesitio composition.

Upper Alignment

24.10 At the upper alignment river gravels rest upon rhyolite on the right bank at an elevation of $28.9 \mathrm{~m}$. as determined by A.E. Pallister. On the left bank the height of the rock is even less, being only $20 \mathrm{~m}$. above river level. During an earlier régime of the Rud-i-Gaz, the river had formerly cut a channel behind the rock on the left bank, almost down to present river level. This channel is now filled with gravels and topped by talus which has descended by gravity down the slopes on the left side.

24.11 The rhyolites dip steeply into the left abutment, but the rook of this abutment is only an isolated mass, flanked on the south side by the trench which is now filled with eravels and talus.

24.12 It would be possible to construct a concrete dam within the rhyolites which would be $80 \mathrm{~m}$. long at an elevation of $+29 \mathrm{~m}$., but the south flank of the dam would have to be built of rock-fill material, since this would rest on gravels.

24.13 As the percolation path through the gravels on the left abutment would be not greater than $100 \mathrm{~m}$., there would be a risk of piping, and this would endanger the stability of the part of the dam that was construoted upon the gravels.

24.14 Because of the composite nature of any dam that would be constructed at this alignment, and of the low height, the locality need not be considered further.

Lower Alignment

24.15 The lower alignment, situated about 400-500 m. downstream of the upper one, and possibly $3 \mathrm{~m}$. lower in elevation above sea level, would be orientated almost due north-south (magnetic $5^{\circ}-185^{\circ}$ ) whereas the river in this part runs in a $125^{\circ}-305^{\circ}$ direotion. The top of the rock below river gravels was found by A.E.Palliater to be $36.3 \mathrm{~m}$. above river level, and the width at this elevation between the two abutments is about $155 \mathrm{~m}$. 
24.16 The rocks at this site are bedded rhyolites which dip $50^{\circ}-60^{\circ}$ towards a direction of $165^{\circ}$ or S.S.E. The consequence is that the rhyolite flows strike obliquely across the valley and the dam would rest across at least 3 major lava flows, as well as upon the softer volcanic elements which occur between the flows.

24.17 River gravels occupy the right abutment above a level of $36.3 \mathrm{~m}$. from the river bed.

24.18 The highly jointed and broken nature of the rhyolites would require much stripping if a concrete dam were to be constructed. The site would take a rock-fill structure, except that impervious roll-fill material is absent, and there is no natural spillway.

24.19 This site is slightly superior to the upper one, but even so it cannot be strongly recommended. Bed level being about 3 metres lower than at the upper site, the effective increase in possible height over the upper site is only $4.4 \mathrm{~m}$., and the increase in storage that would be gained by the extra 4.4 metres, above the possible $15,000,000 \mathrm{~m}^{3}$ that might be impounded by the upper dam, is not likely to be considerable.

\section{Conclusions}

24.20 It is not therefore considered that a suitable dam site exists in this part of the Rud-i-Gaz gorge.

24.21 A study of the topographical sheet $415 \mathrm{~B} / 3$ indicates that there is another narrow reach of the Rud-i-Gaz further upstream at $33^{\circ} 49^{\prime}$ : $62^{\circ} 39^{\prime}$, but it was not possible to visit this location due to its inaccessibility. The catchment upstream of the more distant site is only about $650 \mathrm{Km}^{2}$, and the runoff might not exceed $60,000,000 \mathrm{~m}^{3}$.

\section{Adraskand South of Shindand}

\section{Location}

24.22 About $32 \mathrm{Km}$. south of Shindand the Adraskand leaves its open and much cultivated valley and enters a gorge in Cretaceous linestones at coordinates $33^{\circ} 01^{\prime}$ ' 62009 ' in topographical sheet No. $415 \mathrm{E} / 3$, at an elevation of about $940 \mathrm{~m}$. The river then runs through the Mil Koh range for a distance of $24 \mathrm{Km}$. until the valley widens out at Jija Sarai.

24.23 At the time of visit on 21.3.61 the Adraskand was in flood, and could not be crossed on foot. A compass and tape survey along the right bank indicated that the gorge narrows from 120 metres width to 80 metres. Massive Cretaceous limestone, with sporadic fossils, shows dips ranging from $50^{\circ}$ to $30^{\circ}$ in an ESE direction, or downstream. The limestone overlies thin-bedded limestones and shales, which in turn rest upon Flysch.

24.24 The gorge would certainly be suitable for the construction of a dam 50-100 metres in height. The actual height would however be limited by the existence of a saddle $5 \mathrm{~km}$. west of the gorge which may have an elevation of about 980 metres. Unless this saddle were blocked, water from the reservoir would spill over and enter the Adraskand through the gap in the range which is $7 \mathrm{Km}$. south-west of the dam site. 
24.25 Even a dam 40 metres in height would create a reservoir which would flood back towards Shindand and destroy much valuable cultivated land. Consequently, it is not considered that this dam site requires further investigation.

24.26 A moderately narrow section of the Adraskand, of possibly 500 metres width, exists a short distance upstream of Jija Sarai, near coordinates $32^{\circ} 54^{\prime}, 62^{\circ} 03^{\prime}$, but this was not visited. The gradient of the river in its passage through the Mil Koh range is approximately $1.3 \mathrm{~m} / \mathrm{Km}$. according to the topographical sheets received in 1963. This is a very low gradient for Afghanistan, and considerable storage might be achieved within the range, and without destruction of the valuable cultivated land which is nearer to Shindand. 
CHAPTER 25 - KASH RUD : AIR RECONNAISSANCE

25.1 The Kash Rud emerges from its course through the Flysoh mountains, and flows along an inoised channel within Plio-Pleistocene gravels. At Dilaram the ohannel must be at least 30 metres below the flat plateau-like top of these gravels.

25.2 Within the mountains the course of the Kash Rud is extremely meandering, so muoh so that it was often difficult to piok up the river from the air photographs on account of the most intricately carred channel through the monotonous Flysch. It was quite clear that no large storage could be obtained along this river. An earlier investigation of the soils of the Bhakwa plain by the Helmand Valley authority did not indicate ary soils of good quality in the area, and consequently the present Speoial Fund project did not oonsider it necessary to devote muoh time to the Bhakwa plain.

25.3 Sinoe, however, there had long been a desire by the Government to develop the Bhakwa plain west of Dilaram and south of the Siah Band Koh, possible sources of water had to be considered for this area. It was at first wished that the Special Fund Project should investigate a scheme for bringing water from the Farah Rud by oanal and tunnel through the Siah Band Koh in order to irrigate the Bhakwa plain. On acoount of the great extent of high ground, exceeding 1500 metres in elevation, between the Farah Rud valley and the Bhakwa plain, suoh a scheme would have required extremely costly open channels and tunnels and was manifestly not economic. Consequently, it was preferable to oonsider diversion of water from the Kash Rud valley rather than from the Farah Bud. The Kash Pud is the only perennial stream in the area.

25.4 An alternative proposal for developing the ground-water potential of the Bhakwa plain has also been under consideration, and it is understood that suoh a scheme will be one of the problems under investigation by a Special Fund ground-water survey.

25.5 While the Land and Water Resources team of the Special Fund did not actually visit the mountainous course of the Kash fud on the ground, it may be of interest to detail observations which were made from an Ariana air plane while flying from Herat to Kandahar. The civil airline route crosses the Kash Rud over a wide range of courses, depending on meteorological conditions. On 25th Jamuary, 1962, as well as on 25th July, 1963, the routes passed just south of a possible dam site which is located at coordinates $32^{\circ} 22^{\prime}: 63^{\circ} 45^{\prime} 22^{\prime \prime}$. This location is 38 air-kilometres E.N.E. of Dilaram, and 9.25 air-kilometres upstream from the exit of the Kash Rud from its mountainous course.

25.6 The dam site is located on a N.W.-S.E. bend of the river, along which Flysch sediments dip steeply downstream towards the south-east. North of the left abutment there is a weak zone which is orientated WNW-ESE and may represent either a fault or a zone of shearing. There is no doubt from the nature of the terrain that the Flysch at the dam site must consist of the normal association of calcareous sandstones and calcareous shales. The gorge would take a dam of 50-70 metres height, and the crest length might be between 150 and 200 metres.

25.7 A.E.Pallister has estimated from the advance copies of the topographical sheets that a dam 48 metres in height would store about $92,000,000 \mathrm{~m}^{3}$. This is certainly not a good storage capacity and would presumably only be considered if other means of watering the Bhakwa plain are not feasible. 
25.8 It should be stressed that any oanal that might be designed to oarry water from the Kash Rud to the Bhakwa plain would have to avoid the strongly incised part of the river near Dilaram in order to obviate pumping lift. The canal take-off would thus have to be a long distance upstream of Dilaram, approximately at the nodal point where the river leaves the Flysoh and enters the cover of Plio-Pleistocene gravels.

25.9 W.N.W. of the Kash Rud there is a non-perennial stream which is not inoised. At coordinates $32^{\circ} 34^{\prime}, 63^{\circ} 34^{\prime}$ a constriction in the valley might serve as the site for a dam, but the dam would be some 400-500 metres long for a modest height. This river normally only supports sub-surfaceflow through the river gravels, and it is doubtful if such a site would be economic. 


\section{CONTENTS}

Chapter 26 KABUL RIVER SYSTEM (GENERAL)

Investigations Undertaken Topography and Structural Setting Position of the Kabul River System

27 KAJAO DAM SITE : LOGAR RIVER

Location

Previous Work

Regional Geology

Disposition of the Formations

Location of the Dam

Fractured Nature of the Quartzites

Seepages and Open Joints

Reservoir Impermeability

Raw Materials for Construction

Conclusions and Exploration

28 TANOI SAIDAN DAM SITE : BALA MAIDAN RIVER

Location

History of Investigations

The Gorge and Reservoir Basin

Geology

Tangi Saidan Gorge

The Right-Bank Saddle

Choice of Alignment

Raw Materials for Construction

Exploration

Main Dam

Saddle

Conclusions

Report on the Geology of Tangi Saidan

by Mr. J.P. Hunger, Mineralogist,

U.N.T.A.B., Kabul

$45-55$

Comment 
aps

Map 17 Goological Map of the Kajao Dam Site

18 Geologioal Map of Tangi Saidan Dam Site (by J.P. Hunger, Mineralogist, UNTAB, Kabul) 
CHAPTER 26 - KABUL RIVER SYSTEM

\section{Investigations Undertaken}

26.1 Little geological work has been done by the Special Fund in the Kabul river basin. The area bas been the subject of study by several geologists, including H.H. Hayden, and more recently by continental geologists attached as temporary Professors to Kabul University. It is probable that several technical papers have been published on the results of their researches, but the writer has not yet been able to locate them.

26.2 Detailed geological work was undertaken in conneotion with the Kajao dam site, which is described in Chapter 27. An investigation was also made of the Tangi Saidan gorge on the Bala Maidan, near Kabul, but the detailed mapping of this gorge has been the work of Mr.J.P. Hunger, Mineralogist, U.N.T.A.B., Kabul, and was carried out in the summer of 1962 while the writer was away from Afghanistan. J.Y. Hunger's geological map is published in this volume, together with a summary of his geological conolusions, which forms the second half of Chapter 28.

26.3 Traverses were made up the Panjsher and Ghorband rivers, but the work was of a very cursory nature, and it is thought advisable to postpone discussion of these two branches of the Kabul river until a further examination may be possible under what is hoped will be the second phase of the Special Fund operations.

\section{Topography and Stmuctural Settinf}

26.4 The most striking feature of central Asia is the bunching together of the mountain chains from both the east and west sides. The Himalaya, Karakoram, Kuen Lun and Tien Shan all approach towards the Hindu Kush and what may be called the Pamir "Knot". Similarly, there is a convergence towards the Pamir from the west of the Sulaiman, Toba, Koh-i-Baba and Parapomissus ranges. It is sienificant that within this concentration of fold systems around the Pamir Knot there is an arcuate zone of deep-focus seismicity which is $600 \mathrm{Km}$. in length and $150 \mathrm{Km}$. in width, and has been well figured by Vvedenskaya. This zone of deep-focus earthquakes is named the "Hindu Kush Source" by Gutenbere and Richter, and an average depth of $220 \mathrm{Km}$. is indioated for the origins of the shocks in the area. It would appear probable that this syntaxis of folds has resulted in a deep sub-crustal extension of the continental orust into the underlyine Sima zone.

26.5 Although these mountain massifs may be called ranges, in general they lack the singular and extended orographical orientation which is characteristic of the Great Himalayan and Karakoram ranges. It is suggested that this lack of any persistent orientation, and the splaying out of the folds in the form of a fan, may be connected with rotational movements during the period of Himalayan folding. This folding resulted from the compression of the Tethys geosyncline between the approaching continental shielde of Angaraland on the northern side, and Gondwanaland (peninsular India and Arabia) on the southern side. There were probably rotational movements between the two blocks around the hinge area of the Pamir Knot, with the development of couples rather than straight compression. 
26.6 While on a small-scale map it is possible to demarcate the Hindu Kush in a general manner, in detail it is more difficult to assign the name to any particular orographic feature. This is because the Hindu Kush constitutes a bundle of ranges, which diverge towards the west. The Salang Range $(5480 \mathrm{~m}$.$) north of the Panjsher$ muns W.S.W. to the north of Bamian. The Mir Samir range (Mir Samir $6060 \mathrm{~m} .35^{\circ} 35^{\prime}$, $70^{\circ} 10^{\prime}$, and peak $6293 \mathrm{~m}$ ) contimes beyond the Charikar gap and splits up into the Koh-i-Baba range $(5142 \mathrm{~m}$ ) and the Paghman range $(4700 \mathrm{~m}$.$) .$

26.7 Further south there is another mountain massif in the form of the Safed Koh Range (peak Sikaram: $4760 \mathrm{~m}$ ) which lies between Jalalabad and Parachinar. Towards the east this range forms the zone of metamorphic rocks which continues south of Peshawar across the Indus and loses its individuality in Hazara (not the Hazarajat of Afghanistan) near Abbotabad. This range belongs to the Attock Slate and Simla Slate foundation of what the writer has termed the Peninsular Himalaya (The Structure of the Garhwal Himalaya: Rec.Geol.Surv. Ind., 71, 1937).

26.8 South of the Safed Koh in western Pakistan is the Kala Chitta or Margala zone of overthrust Mesozoic and. Tertiary rocks which is well developed between Kohat and Haripur. The Kala Chitta stratigraphical succession belongs strictly to the IndoPakistan province, and is not connected with the Flysch and Eocene zone between the Chaman and Sulaiman faults.

26.9 The western extension of the Safed Koh is almost certainly the mountain massif which strikes N.E.-S.W. between Ghazni and Gardez, and the Safed Koh under-

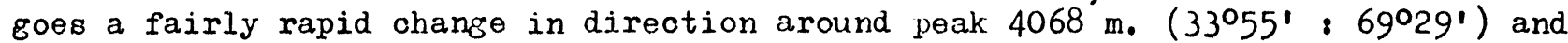
peak 4279 , in a manner recalling the change in direction of the Mir Samir range into the Paghman range across the Charikar gap.

Position of the Kabul River System

26.10 The zone between the Safed Koh and Gardez massif on the south, and the Mir Samir-Paghman massif further north has been the locus of movements along faults, possibly with a transcurrent horizontal component. One prominent fault runs along the longitudinal depression followed by the Kabul-Ghazni road, and is almost certain ly an extension of the Chaman fault which is known to run from north of the Makran to near Mukur, over a length of $700 \mathrm{Km}$. (Chapter 4 para.7).

26.11 The southern branches of the Kabul river system occupy this zone between the two massifs. Within this zone there is a profusion of ridges which lack orientation, and which separate the region into basins and broad valleys or depressions of irregular shape.

26.12 The Ghorband and Panjsher valleys, on the other hand, mun along strike valleys which are controlled by faults and folds which possess a moderately continuous ENE-WSW orientation, related to the Salang range.

26.13 The Kabul basin was evidently at one time filled with Neogene conglomerates, sands and silts. These formations were subsequently eroded and now remain as residual plateaux upon which have been constructed forts, and on one of which is the tomb of Nadir Shah. Recent alluvium now occupies the whole basin between the walls of limestone and metamorphics and the residual masses of Neogene sediments. The thiokness of the Neogene and alluvial sediments is not known, so far as the writer is aware. The valley would certainly be a favourable terrain for conducting a refraction seismic survey, since there should be considerable contrasts in elastio properties between the alluvium, the Neogene, and the mainly metamorphic floor. 
26.14 Numerous ancient river terraces exist in the Charikar area, while on the flanks of the Shakardhara and Ghorband valleys are large-boulder deposits of probable fluvio-glacial origin. Such a terrace is well exposed in the Ghorband valley opposite the Nanakab, $31 \mathrm{Km}$. upstream from its exit into the Charikar valley. 
$\frac{\text { CHAPTER } 27 \text { - KAJAO DAM SITE : LOAAR RIVER }}{(\text { MAP 17) }}$

Introduction

\section{Looation}

27.1 Exact geographical coordinates for the Kajao dam site oannot be given until the new topographical maps are recoived from America, as this is one of the few areas in Afghanistan where the earlier reconnaissance sheets are quite inaccurate. The dam site is looated approximately as follows:-

\author{
Coordinates \\ Air distance from kabul \\ Air distance from Chuka \\ Wardak Dam \\ River distance above \\ Chuka Wardak Dam \\ Road distanoe from Kabul \\ Elevation \\ Air Photographs
}

\author{
$34^{\circ} 14^{\prime}: 68^{\circ} 30^{\prime}$ \\ $70 \mathrm{Km}$. W. S.W. \\ $17.5 \mathrm{Km}$. N.W. (determined \\ from air photographa) \\ $28 \mathrm{Km}$. \\ $130 \mathrm{Km}$. \\ $2,300 \mathrm{~m}$. \\ $62-A / 9852-9853$ \\ 62-B/ 9634-9635
}

\section{Previous Work}

27.2 A preliminary geologioal report was prepared by the writer in August 1962, at a time when J. Rijedijk, Topographical Engineer, had just started preparing a 1.2000 map of the area. For insertion of geological details a compass and tapemeasure sketch map of the gorge was prepared in August 1962 on the soale of 1:2000, whioh was provisional until the topographical map had been completed.

27.3 The topographical map was finished in November 1962, and the writer returned to Kajao in June 1963 in order to add the geological details. Little change in the geological conolusions regardine the dam site itself proved to be necessary, but the regional structure became even more obscure than it was originally thought to be.

\section{Regional Geology}

27.4 Until 1963 no regional geological survey had been made of the area, but work was then begun by the German Geolofical Mission. The writer did not have access to the results, but did once discuss the problem of suocession with Herr Klaus Fesefeldt who had visited the Kajao.

27.5 Mxch of the area between the main Kabul-Ghazni road and Kajao consists of epimetamorphic argillaceous rocks in the form of slates and phyllites. Granite injectIons are common west of the main road just north of Top, and also $17 \mathrm{Km}$. west of Top. A remarkable band of grey limestone with chert, not less than 500 metres in thickness, occurs as a vertical outcrop striking N.E.-S.W. across the road $15 \mathrm{Km}$. from Chuka Wardak towards Kajao. This limestone has brachiopod fossils and may be Palaeozoio in age. 
27.6 Between this limestone and Kajao the predominant rock, over a road distance of $28 \mathrm{Km}$., is slate with minor bands of quartzite. Dips are usually steep, and within $2 \mathrm{~km}$. of the kajao grorge there is an anticlinal axis.

27.7 The dam site itself is located within a vertical band of quartzite which strikes ENE-WSW and has a thickness varying from 200 to 220 metres.

27.8 North of the dam site there is another zone of slates, similar to those on the south side with the exception that they lack the minor bands of quartzite. These slates are also anticlinal in structure, the axis of the anticline being 800 metres north of the dam site.

27.9 North of the slates is a further band of quartzite, slightly more argillaceous in appearance than the dam quartzite. The tentative conclusion is that the two bands of quartzite are the same, and represent two limbs of the northern anticline. It should be noted, however, that the southern anticline does not cause any repetition of the main massive quartzite in that direction.

27.10 The geometry of these two apparent anticlines in relation to the dam quartzite is not understood, and would require much more extensive field work than it was possible to give. One flank of the quartzite may in fact represent a thrust plane, with the result that one anticlinal unit is thrust upon another anticline, with virtual elimination of the intervening syncline.

27.11 Klaus Fesefeldt believes that the slates on the north and south sides of the dam quartzite are the same, and that the quartzite occurs as a syncline between similar slates. It is generally unsound to attempt a study of regional stmucture on the basis of field work confined to a very limited area, and the writer is reluctant to disagres with a geologist who has had a more extensive experience of the particular region. The following points may, however, be mentioned in connection with this problem.

(1) The dam quartzite occurs as an outcrop of more than $10 \mathrm{Km}$. lateral extent, and between elevations 2300 and $2700 \mathrm{~m}$. If the quartzite were a synclinal wedge embedded within identical slates, signs of its downward termination at the axis of the syncline should be observable within the height difference of 400 metres in which it is exposed. The only synclinal wedreout is in fact on the right bank just downstream of the dam site, but this represents a buckle in the main mass of quartzite that has been thrust over the group of slates and quartzites which crop out on the south side. It is true that on the west side of the river the quartzite is sheared off into a series of lenses, but such shearing is part of the system of N.W.-S.E. faults which affects the whole outcrop.

(2) The slates on the south side of the dam quartzite have numerous bands of quartzite up to 12 metres in thickness, which stand out as ribs that are more resistant to erosion. The slates on the north side of the dam quartzite, at least in the area studied, have no thin bands of quartzite. If the dam quartzite were present in the form of a syncline, it would have been expected that the slates of both north and south limbs of the supposed syncline should have similar bands of quartzite, and the same thin bands of quartzite which occur on the south side should also be present on the north side. In fact, however, 
thin quartzite bands are absent in the northern group of slates. One further difference, which may also be diagnostic, is the fact that the slates on the north side of the Dam Quartzite possess a well-developed cleavage, while those on the south side are not oleaved in any marked degree.

27.12 Provisionally, therefore, and without any wish to be dogmatio over the issue, it is suggested that there are in fact two distinot groups of slates, separated by 200-220 m. of the Dam Quartzite. The point at issue is not entirely academic. If the quartzite occurs in the form of a tight syncline, between identical slates, it should wedge out at depth a short distance below Kajao river level. If, on the other hand, the slates are distinct, and the quartzite represents an arenaceous zone between slates of different ages, then the quartzite should contime in depth. The formations present at Kajao are given in the table below:-

\section{Formations Present at Kajao}

$\begin{array}{lll}\text { Recent } & 6 & \text { River Gravels } \\ \text { ? Pleistocene } & 5 & \begin{array}{l}\text { Large-boulder gravels of terraces, at } \\ \text { various levels. }\end{array} \\ 4 & \begin{array}{l}\text { Lacustrine silts, sands, gravels and } \\ \text { extensive calcarous tufa or travertine, } \\ \text { occupying terraces on previously eroded } \\ \text { slates. }\end{array}\end{array}$

Group of slates and quartzites on the south side of the Tangi Dam Quartzite. Cleavage not well developed.

Metamorphic

Lower Palaeozoic
200-220 metres of massive quartzite, forming the dam site.

Group of slates, without thin quartzite bands, on the north side of the Dam Quartzite. Well developed cleavage.

27.13 The slates on the north side of the Dam quartzite are assumed to be older than the quartzite, and to form the core of the anticline which has caused the repetition of the Dam Quartzite still further north. The slates dip southwards near the Dam Quartzite, but 800 metres to the north of the gorge is an anticlinal axis, beyond which the slates have a steep northern dip. Cleavage dip is vertical on the north limb of the fold, and southwards on the south limb, near the quartzite.

27.14 From an engineering point of view the question as to which beds are older and which younger is not of much practical importance at this particular dam site. The significant feature is that the Dam Quartzite is flanked on both the north and south sides by slates, and that the slates are impermeable. The two groups of slates, and the intermediate Dam Quartzite that lies between them, are considered to be vertical units in the limb of a major fold, and the problem of the stratigraphic geometry is irrelevant to the question of stability and watertightness, provided that the slates are of different ages. The geometric relationships are only impor- 
tant in this case if the northern and southern slates are of the same age, and the quartzite suddenly terminates at depth in the core of a syncline. Even if this synolinal disposition ultimately proves to be the correct one, no problem arises in regard to permeability but solely in regard to the depth to which the quartizite extends as a stable foundation to the dam.

Lithology

27.15 The main quartzite, which is 200-220 metres thick on the east side, but somewhat thicker in the main outcrop on the west side, is a clastic quartzite with a cement of secondary silica. It occurs as thick beds, individually up to 2 metres, without any noticeable shale breaks. It may be stated that the quartzite possesses no matrix porosity on account of the silica cenent.

27.16 The main quartzite is affected by very pronounced joints and shear zones. Indeed, so stronely developed are these features that in certain exposures they dominate over the true beddine planes. This is particularly marked on the east side of the gorge north of tric. station 19, where joint planes dipping $50^{\circ}$ north are extremely conspicuous. The true bedding planes are however manifest on the east bank about 100 metres above river level.

27.17 The abundance of these beddinf, joint and shear planes must $\varepsilon^{i v e}$ to the Dam Quartzite a very stronf permeability notwithstanding the lack of matrix porosity and permeability within the actual mass of the material. One of the principal functions of the exploration will be to establish the distance at which the open beddine, joint and shear planes close away from the exposed abutment surface.

\section{Disposition of the Formations}

$27.18 \mathrm{As}$ already stated, the quartzite, together with the slates which flank it on both sides, dip vertically, and strike in an ENE-WSW direction. The quartzite at the south end of the Tangi on the west bank is sharply folded in on itself in the form of a tight "S", and the fold is dislocated by a reversed fault which has brought the quartzite abruptly to truncate the slates and thin quartzites of the youngest of the three units. This reversed fault is orientated N.W.-S.E.

27.19 A study of the air photographs shows that similar dislocations of the main quartzite are very marked on the west side of the Tangi throughout a distance of $6 \mathrm{Km}$. from the dam site. The quartzite bend is sheared off along N.W.-S.E. faults in an echelon manner in the form of lenticular masses surrounded by the younger and older slates which in many places must be in juxtaposition.

27.20 All these dislocations are evidently of a secondary nature, in as much as they are thought to occur within the single limb of a major regional fold.

27.21 In addition to the "S" fold and thrust fault which are evident on the west side of the river mouth of the Tangi, there is a NNW-SSE cross-fault running along the axis of the Tangi, which has resulted in the dislocation of the quartzite band. The horizontal component of movement along this fault is about 60 metres, with the east side moving that distance south relative to the west side. 
Location of the Dam

27.22 The topography of the corge indicates that any dam that might be constmucted would be located mainly upon the Jarn cuartzite, which in the grorge is 200-220 metres in horizontal extent. On account, however, of the river fault mentioned in the precedine paragraph, the quartzite has been displaced by horizontal movement. As a consequence, the net width of quartzite on the west side of the fault that abuts against quartzite on the east side of the fault is not greater than 180 metres. This width may be less than 180 metres, because there is some uncertainty about the extrapolation of the boundary between the northern slates and the quartzite under the bed of the river on the two sides of the fault. The minimum net width may be 140 metres.

27.23 In the event of a concrete dam being constructed, it is the net width of quartzite in juxtajosition between the two blocks that have been faulted which is important, since it is assumed that a concrete dam would be confined to the quartzite, and would not be based on either the northern or southern slates. Since a base width of 140 metres would permit of a concrete gravity dam of at least 100 metres height being constructed (allowing for some quartzite in the river bed being left free of dam at upstream heel and downstream toe) there is evidently sufficient net width of quartzite to accornmodate any concrete structure that might be built in the forge. On the other hand, a rock-fill dam of height 100 metres would ocaupy a base width of not less than 300 metres, and possibly 350 metres. Consequently, a rock-fill structure would of necessity overlap across the confines of the quartzite and rest in part upon the northern and southern groups of slates.

27.24 Any dam that is constructed in the gorge would rest across the river fault. This fault has not been seen in any exposed form, but must definitely exist on account of the very clear horizontal shift between the quartzites of the two abutments. The fault lies totally concealed below river gravels.

\section{Topography of the Gorge}

27.25 The width of the gorge between the cliffs varies from 56 to 62 metres in the narrow seotion. The right bank has a vertical cliff for 10 metres, and then slopes upwards with a gradient of $1: 1.2$. The left bank has a very steep cliff for a height of 80 metres, above which the ridge slopes much more gently with a gradient of 1:2.5. The cross section of the gorge is thus unsymmetrical. This fact, and the broken nature of the quartzites, would suguest that an arch-type of dam would not be suitable, and that a concrete gravity structure is preferable.

27.26 The depth of gravels in the gorge is not known. It may be assumed to be 5-10 metres for preliminary design purposes.

\section{Fractured Nature of the Quartzites}

27.27 The main Dam Quartzite is manifestly very fractured. Movement on a minor scale has taken place along the bedding planes and joints, with the result that these are open at the surface and give the impression of remaining open a considerable distance into each abutment. In addition, there are numerous inclined planes alone which more considerable movements have taken place, sometimes with fracturin; of the rock. Some of these planes justify the term "shatter zone". They are well developed on the left bank upstream of the probable dam axis. 
27.28 It is impossible without driving tunnels into the banks to indicate just how deep these open features extend into the hill side, and this will be a primary object of the exploration programme. It would not be surprising if the divisional planes remain open up to 20 metres within each abutment, but tunnel exploration is essential to establish where the divisional planes olose and beoome tight. It may be mentioned that the Speoial Fund team was able to visit the Naghlu dam site on the Kabul River through the courtesy of the Soviet engineers. This site shows a great profusion of open joints within the gneiss, but where the right abutment was penetrated by a tunnel near the proposed dam axis there was a relatively rapid closing of the joints away from the exposed hill side. It may be, therefore, that the oliffs of quartzite at Kajao present an over-pessimistic impression in regard to the amount of stripping which will be necessary in order to reach compact rock free from open bedding planes and joints. Nevertheless, the writer would suggest that any design for a concrete dam in the Kajao gorge should allow for not less than 10 metres of strippine on either abitment.

\section{Seepages and Open Joints}

27.29 A small seepage issues from the quartzite on the left (east) bank about 40 metres above river level and 90 metres north of trig. station 19. This seepage is associated with one of the northward inclined joints along which some shearing has taken place. Water percolating into the quartzite from rainfall on the ridge is confined by the slates which lie on both sides of the quartzite. The water thus travels within the quartzite down the joints and beddine planes, until it finds an exit on the oliff face.

27. 30 There is another seepage associated with the junction between the dam quartzite and the adjacent slates 800 metres ENE of trigestation 19 and at an elevation of about $200 \mathrm{~m}$. above river level. At this place there is a large mass of travertine and the first impression is that the travertine has been produoed by the spring. It is difficult to accept this conclusion, since neither the quartzite nor the slates contain appreciable amounts of calcium carbonate, and there is consequently no source of carbonates from which the ground water could aoquire caloium bicarbonate and liberate travertine. It is conoluded that this particular travertine is part of the extensive development of travertine that is present along the Kajao valley, especially upstream of Saidan village, and which was formed during an earlier régime of the river when the Kajao river was issuing from a limestone terrain and depositing travertine in lakes in a manner similar to Band-i-Amir. The small spring near the dam site issues from the quartzite, and is now camsing a re-distribution of caloium oarbonate as a secondary travertine cone located upon the original and ancient travertine terrace.

27.31 The open joints, shears and bedding planes have been caused by the teotonio forces to which the quartzite has been submitted, and not by chemical solution. They will certainly require an elaborate and costly grout programme.

\section{Reservoir Impermeability}

27.32 The reservoir will be located principally on slates of the northern group. The band of quartzites which is $2 \mathrm{Km}$. north of Saidan village converges to the Kajao river $5 \mathrm{Km}$. upstream of Saidan. It is possible, as stated above, that this band is a repetition of the dam quartzite, duplicated by folding, although it appears to be more slaty than the rock which occurs at the dam site. 
27.33 A third formation is present in the large masses of travertine which are present in the form of terraces from Saidan village itself westwards to beyond Dharani village. It is suspected that the large outcrop showing grey white in air photocraph $62 / 19299$ between the two main branches of the Kajao is also travertine.

27.34 In spite of the abundance of travertine, wherever seen it lies on slates or quartzites, from which it cannot have been derived. As exposed on cliffs above the river it rests on a platform of slates and must have been built up in a lake which formerly ocoupied the valley, perhaps due to a natural dam. The Kajao river later cut down through the travertine deposits and deeper into the slates upon which the travertine reats.

27.35 It is considered that there is no need to suspect leakage from a reservoir in this valley, for the travertine has no visible connection with limestone outcrops, and the true floor of the valley is predominantly slaty and impermeable. The bands of quartzite which occur within the reservoir basin, such as that $5 \mathrm{Km}$. west of Saidan village, are open jointed, but at depth these joints must certainly close and the quartzite cannot be considered as a conduit which will lead water from the reservoir outside the basin.

Perrneability at the Dam Site

$27.36 \mathrm{As}$ pointed out in paragraph 27.11 , the main quartzite upon which the dam would be built is bounded both to north and south by slates and phyllites. This band is almost vertical, and continues to depth below river level. It has no matrix porosity or permeability, but must possess strong joint permeability on the abutments of the Eorge. Below river level such joints and bedding planes as are open may be regarded as saturated, and it is not considered that any loss of reservoir water could occur into the quartzite below bed level. These open planes must close at a shallow depth.

27.37 The losses which might occur through both abutments on account of the open nature of the joint and bedding planes will have to be counteracted by a grout programme. To discover the nature of these open planes within the abutments it will not be enough merely to undertake diamond drilling. It will be essential to drive tunnels into both abutments in order to obtain a visual impression of the nature of the open planes and other weak zones. Diamond drilling will also of course be required, in particular to test the extent of water-loss under pressures of up to $20 \mathrm{Kg} / \mathrm{cm}^{2}$, and the amount of cement-grout that would be accepted,

\section{Raw Materials for Construction}

27. 38 There is a deficiency of impervious material in the river terraces which could be used for the impervious roll-fill section of a rock-fill dam. It is possible that the fields upstream of Saidan village may have a sufficient percentage of clay fraotion in the soil to provide impermeability, but a large area of cultivation would have to be scraped in order to collect enough material.

27. 39 There is an abundance of boulder gravels in the form of dissected terraces both upstream and downstream of the dam site. The material in places has the aspect of glacial moraine, with boulders up to $1.5 \mathrm{~m}^{3}$ in volume, although the more nornal diameters of the boulders are between 20 and $30 \mathrm{~cm}$. Upstream of the dam site there is a large proportion of limestone with subordinate quartzite. Downstream of the dam site limestone is scarce, and the majority of the boulders are of quartzite, with some quartzitic slate. 
27.40 Estimates of volume are difficult in the case of the terraces just opposite Saidan village on account of the very variable elevation of the slate platform underlying the gravels. The terrace which is $500 \mathrm{~m}$. ENE of Saidan village covers about $20,000 \mathrm{~m}^{2}$, and may have volume of $200,000 \mathrm{~m}^{3}$.

27.41 The largest accumulation of boulder gravels is on the left bank of the river $1.5 \mathrm{Km}$. SSE of the dam site. This terrace is over $2 \mathrm{Km}$. in length in an east-west direction and $1 \mathrm{Km}$. in breadth near the road.

27.42 It should be stressed that if these terraces were to be exploited as a source of aggregate for the dam concrete, most of the boulders would have to be crushed on account of their larese size. Inasmuch as the terraces do have non-quartzitio elements in them, the aegregate material derived from them would be somewhat heterogeneous. Finally, the material would have to be transported by truck or endless belt from the quarry to the dam site.

27.43 It is possible, therefore, that the most convenient source of aggregate would be the quartzitic outcrop on the west bank of the gorge immediately overlooking the dam site. The quartzite would have to be quarried and crushed, but could be brought down by gravity straight to the dam, without the necessity of long haulace. Moreover, the quartzite is homogeneous, and the aggregate would be of uniform composition. The same quarry could produce the fine aggregate or sand, with closer crushing.

27.44 The nearest cement works to Kajao is $210 \mathrm{Km}$. distant by road.

Conclusions and Exploration

$27.45 \mathrm{It}$ is considered that the Kajao gorge just downstream of Saidan village is a feasible site for the construction of a concrete gravity dam upon an almost vertical band of quartzite 200-220 $\mathrm{m}$. in width.

$27.46 \mathrm{~A}$ fault runs along the axis of the gorge, and the quartzite abutments are interseoted by numerous open joints, shear planes and bedding planes. Foundation treatment will certainly be costly, and will involve undertakins a very extensive grout programme.

27.47 The reservoir will be located on a foundation of slates and quartzites, and should be impermeable. The almost vertical quartzite at the dam site is flanked on both sides by impermeable slates. Leakage through the quartzitic abutments above river level can be obviated by means of the grout programme. No leakage can take place from the quartzite band in a downstream direction since the band has an almost vertical contact with extensive impermeable slates on the south side.

27.48 The abutments will require 4 exploratory tunnels, 2 on each side, and the tunnels will have to be approximately of $100 \mathrm{~m}$. length.

$27.49 \mathrm{~A}$ shaft, leading to an under-river tunnel, will be required in order to explore the concealed fault which runs along the axis of the gorge.

27.50 Borings will be required in the river bed to determine the thickness of river gravels.

27.51 Extensive water-pressure tests will be required on both abutments from diamond drill holes. These holes will have to be $100 \mathrm{~m}$. in length. 
27.52 It is ouggested that the most convenient source of a consistent aggregate will be by quarrying and crushing quartzite on the west abutment of the dam site between survey station 13 and the river. 
CHAPTYR 28 - TANGI SAIDAN DAM SITE : BAILA MAIDAN RIVER

(Map 18)

Introduction

Location

28.1 The Tangi Saidan dam gite is located on the Bala Maidan tributary of the Kabul river, west of Rishk or and about $16 \mathrm{Km}$. by road from the Demazang gasoline station. Elevation $1865 \mathrm{~m}$. above sea level. Air Photograph 64/4677.

History of Investigations

28.2 The derman Hydrological Mission in Afghanistan had considered the posgibility of constructing a dam in the Tangi Saidan as early as 1960 but, so far as is known, no investications were undertaken. The Mission installed a gauge at the lower end of the Eorge.

28. 3 In the summer of 1962, when the writer was away from Afghanistan, A.P.Pallister of the Toporgraphical Group, Special Fund, and Mr. J.P. Hunger, Mineralogist, U.N.T. A.B., Kabul, visjted the gorge and decided on the limits of a large-scale topoeraphical map. This topocraphical survey, on the scale of $1: 2,000$. was undertaken by P. Leggiad ro of the śpecial Fund team during August 1962, while J. P. Hunger made a photo-geolofical interpretation of the gorge, selectine four alignments for later study. He later reduced the number of alignments to three.

28.4 In October 1962 the writer made a brief visit to the gorge and suggested that an alicnment located $520 \mathrm{~m}$. on the right bank from the water mill might be the most suitable. (Memorandum dated 3.10.62). It was again necessary to leave Afghanistan before detailed work had been undertaken, and the large-soale geologioal mapping was in fact carried out by J.P. Hunger early in 1963, using the topographical foundation prepared by the Special Fund. J.P. Hunger wrote a report in German on 5.6.63, but no copy of this report reached the Special fund until 9 months later, in March 1964. In the meantime the writer studied the gorge in greater detail during August 1963, in the comvany of Mr. Abdul Rauf, and prepared a report dated 17.8.1963.

28.5 In consequence, there are two reports concerning this dam site. Both are reproduced in this chapter. The geological map, however, is the work of J. P.Hunger.

The Gorge and Reservoir Basin

28.6 The gorge in which the main dam would be looated is about $1200 \mathrm{~m}$. long and averages $100 \mathrm{~m}$. in width between the abutments. It is orientated N.E.-S.W.

28.7 Reservoir capacity has been determined by the topographers to be as follows:Height of dam above River Bed Capacity in Cubic metres

$60 \mathrm{~m}$.

$80 \mathrm{~m}$.

$75,000,000 \mathrm{~m}^{3}$

$170,000,000 \mathrm{~m}^{3}$

28.8 About $2 \mathrm{~km}$. upstream from the east end of the gorge, on the south side of the valley, there is a low saddle which separates the Bala Maidan valley from the Logar valley. This saddle rests across a possible former channel of the Bala Maidan river which is orientated WNW-HSE, and is parallel to another depression which joints the two river systems $2 \mathrm{Km}$. downstream from the eastern exit of the Bala Maidan gorge. 
28.9 The level of the river in the Tangi Saidan at the probable dam alignment is about $1863 \mathrm{~m}$. a.s.l. The lowest point of the saddle $2 \mathrm{Km}$. upstream is $1917.5 \mathrm{~m}$., or $54.5 \mathrm{~m}$. higher than the river bed. In order to achieve a dam in the main valley of $60 \mathrm{~m}$. height above present river level, it would be necessary to construct two subsidiary dams on the saddle 102 and $148 \mathrm{~m}$. in length, a total of $250 \mathrm{~m}$.

28.10 If a dam $80 \mathrm{~m}$, in height above present bed level were considered, in order to store $170,000,000 \mathrm{~m}^{3}$ of water, a subsidiary dam $1020 \mathrm{~m}$. in length would be required aoross the saddle, with a maximum height of $25.5 \mathrm{~m}$. As will be disoussed, such a dam would have to be constructed of earth and rook-fill, and would be of very large volume.

28.11 On eoonomic srounds, therefore, it is possible that a dam oonstructed across the main valley should not exceed $60 \mathrm{~m}$. above present bed level, and that the volume of impounded water in the reservoir would be only $75,000,000 \mathrm{~m} 3$.

Geology

Tangi Saidan Gorge

28.12 J.P. Hunger has recognised the following main rock types on his geological map within the Tangi Saidan Eorge:

Sedimentary

dolomitio and bedded Carboniferous limestones

dolomitic and sandy marbles of pre-Carboniferous age

conglomeratic sohist

black shale and phyllite

Igneous

Diabase and Hornblende Gabbro

Diabase breccia

28.13 The diabase and hornblende cabbro are intrusive into the metamorphic limestones. There is an extensive area on the right (south-east) bank which is coloured green on J.P. Hunger's map and termed "Diabase Breccia". This designation is not altofether suitable for the exposures which are 320-480 m. south-west of the eastern water-mill, for the rocks exposed on the right bank above the highest canal are highly banded, vertical with a $70^{\circ}-250^{\circ}$ orientation, and consist of a complex mixture of phyllite, quartz, calcareous matter, and injection lenses. "Injeotion mélange" may be a better designation.

28.14 Broadly, the oalcareous rocks of the Tangi Saidan have been folded into a major aroh, the dips mainly westerly on the west side, and on the east side towards the east. But. the arch has been broken up by a number of thrust faults, the most conspicuous of which is north-west of the eastern mill.

28.15 A very pronounced weak zone, of vertical sheared limestones, occurs at the downstream end on the right bank, cutting the ridge $300 \mathrm{~m}$. S.S.E. of the eastern water-mill. This weak zone is orientated WNW-ESE, and is thus parallel to the erosion channels, one of which is now occupied by the saddle described in paragraph 28.8 above. 
28.16 It is olear that the dominant direotion of faulting and weakness in the metamorphic rocks of this area is WNW-ESE. A major fault zone along this direction is seen on the air photographs eouth of the Logar river, and is not less than $7 \mathrm{Km}$. in length, terminating about $6 \mathrm{Km}$. E.S. H. of Dar-ul-Aman.

28.17 The discrepancies between the stmoture on the sides of the Tanei Saidan certainly would suegest that a N.E.-S.W. fault may mu along the axis of the gorge. Yet this inferred fault is not seen at the two ends of the gorge, where the river bends to the north-west and south-east, and the more definite direction of weakness is certainly WNW-ESHE, as discussed in paragraphs 15 and 16 above.

28.18 At three places along the axis of the Eorge there are deposits of travertine. These are chemioal deposits derived from springs, and the existence of such springs may possibly indicate that they issue from a fault zone running along the gorge.

28.19 The largest of these travertine deposits is $850 \mathrm{~m}$. south-west of the eastern water-mill, and eives the impression that it might have been derived from spring discharge issuing throuch the alluvial terrace on the left bank. Whether the spring arises from a fault zone, or merely from ground-water migration through the limestones on the left bank, is difficult to determine without further investigation.

28.20 In the south-western half of the corce there is limestone on both banks. According to J.P.Ifuncer, the limestone on the right bank is inverted, and is designated "Ilakenwurf". The north-eastern half of the EorEe has mainly basic iEneous rocks in the lower levels, together with Diabase Breccia and what is suggested (paracraph 28.13) may be called "Injection Mélange". On the right abutment this material dips SSE below limestone. On the left abutment the basic rock dips WSW to SSW below limestone.

28.21 The impress." is thined that the basic rock is probably contimuous below river level in the north-eastern part of the crorge, and that there is a single intrusive mass, located unilerneath the limestone, which has possibly been arched in consequence of the intrusive mechanism.

The Right-Bank Solldle

28.22 As discussed above, there is a low saddle on the right side of the reservoir, which blocks a WWW-ESW valley within the metamorphic rocks. This saddle is composed of alternations of cemented and uncemented Pleistocene conglomerates belonging to the Lataband Series. The alternations of horizontal cemented and uncemented conglomerate are well seen on the small hill close to Lalander village. Cemented conglomerates are found close to the uppermost canal in the embayment leading to the saddle, but in the neighbourhood of the saddle cementation appears to be absent, and the conglomerates are soft and easily weathering.

28.23 It is not known if silts occur within the conglomerate layers, but it is thought that silts, if present, must be very subordinate in amount.

28.24 On either side of the saddle there are metamorphic rocks, but the outcrop of young conglomerates is at least $1 \mathrm{Km}$. wide. The depth of the floor of the young conglomerates below the saddle is not known, but is likely to be around the $1870 \mathrm{~m}$. level.

28.25 On both sides of the saddle there are old karezes, evidently long in disuse, and with the karez shafts all filled in. The karez on the E.S.E. side of the saddle is about $1200 \mathrm{~m}$. long. 
28.26 It is not known if these karezes were ever successful. The fact that they are now blocked and not functioning may indicate that the yield of water was so poor that the expense of maintenance was not considered justified. But the existence of such karezes points to some degree of permeability in the less cemented conglomerates of the Lataband Series. This point is important in connection with the question of the water-tightness of the saddle, if it were to function as part of the reservoir perimeter.

\section{Choice of Alignment}

28.27 It was suggested in paragraph 28.11 that the probable economic height for a dam in Tangi Saidan would be $60 \mathrm{~m}$. above present river level. There are four possible alignments for a dam in this gorge. None is good, and in three alignments the topographically suitable abutments do not face each other orthogonally to the valley axis.

28.28 The alignments are as follows, distances being measured up the valley from the lowest water-mill on the left bank.

No. Approx. Elevation of Valley Bottom

Distance From

lowest Mill

1

1.

1859

$1859 \mathrm{~m}$.

$140 \mathrm{~m}$.

2. 1863

3.

1866

870

4. $\quad 1870$

1080
$215 \mathrm{~m}$.

250

275

Lensth of Dam without stripping up to $60 \mathrm{~m}$. from valley bottom

310
Left Abutment Right

Abutment

Diabase Breccia and

Diabase limestone

Diabase and Gabbro Breccia. Injection mélange. Shear zone

Diabase, Cabbro, Limestone.

Steeply folded limestone on both abutments

West-dipping

Inverted limestone

28.29 Apart from the greater length of the two upstream alignments, the abutments are located on limestone, and the bed foundation is likely also to be limestone. While many dams have been constructed on limestone, it is usually preferable, if alternative non-calcareous formations exist, to avoid limestone, which may require more foundation treatment and grouting. Consequently, it is suggested that alignments 3 and 4 at Tangi Saidan may be abandoned.

28. 30 Alignment 1 is the shortest, but the brecciated nature of the diabase on the left abutment, and the probable proximity of the WNW-ESE shear zone on the right abutment, indicate that the foundation treatment might be considerable. Consequently, it may be suggested that alignment 2, which is 500 metres upstream from the mill, may be the best. 
28. 31 The shortest distance between actual rock outcrops at the No.2 alifnuent is in a WWW-ESE direction, which is very inclined to the axis of the valley. A more suitable direction for the alignment would be NW-SE which would involve the clearanoe of more talus on the left bank. Both abutments would be located on basic rocks, diabase and hornblende gabbro, except for the topmost 10 metres of the dam which would rest on the right abutment upon linestone. No rock is exposed in the bed of the river or along the road, but there is a probability that basio igneous rock is contimuous below the river and would form the foundation of the dam over about 90 percent of its length.

28. 32 There are patches of travertine on this alignment, the origin of which is unoertain. The travertine may, as mentioned in parafraph 28.18 , be connected with a fault running along the axis of the valley, but could have arisen from normal ground-water discharge.

28. 33 It was hoped that it might be possible to construct a rock-fill dam in the Tanei, and to use the saddle on the south-east side of the reservoir as a spillway, with a conorete section of limited volume. The saddle is, however, characterised by mainly uncemented and unconsolidated gravels, and would be unsuitable for the constmuction of a normal type of concrete spillway. Moreover, the soft unconsolidated sediments of the Lataband series continue in an E. S. E. direction towards Chehl-lokhteran village, and if the saddle were unprotected and used as a spillway, there would be serious erosion and the deposition of detritus in the neighbourhood of the village.

28. 34 Consequently, it would appear probable that the saddle cannot be used as a splllway, and would have to be blocked by an earth-fill dyke. Hence the main dam in the Tangi Saidan would have to be constructed of concrete and be employed as a spill for flood-water discharge.

\section{Raw Materials for Construotion}

28. 35 The conglomerates of the Lataband series are partly cemented and partly uncemented. They consist of a variety of limestones, marble, gneiss, cranite, diabase, schist and slate. The majority of the cobbles would be suitable for conorete aggregate.

28. 36 The earth dyke on the saddle could be constructed of the same conclomerates. Impervious material would have to be obtained from the cultivated fields which would be flooded by the reservoir.

Exploration

Main Dam

28. 37 It is quite evident from the discussion above that there are uncertainties about the nature of the rock in the valley bottom of the Tangi Saidan gorge and whother or not the travertine has arisen from spring discharge alone a river fault. These uncertainties could only be removed by an extensive series of borings in the valley bottom, arranged in a grid pattern at 20 metre intervals. The borings will establish both the nature of the bed rock which is now concealed below talus and alluvium, and the linear extent and direction of the possible river fault.

28. 38 If the possible river fault is inclined to the vertical it will be located by normal vertical borings. But such borines might fail to detect a vertical fault, and it would be necessary to drill several anfle-holes in addition to the usual vertical borings. 


\section{Saddle}

28.39 In regard to the saddle there are two main uncertainties. First, it is not known to what extent the conglomerates at depth are cemented. Second, the permeability of the gravels is not known, but a moderate permeability is suspected because of the existence of karezes in the gravels.

28.40 Borings will be required along the saddle to establish the nature of the gravels, and the depth of the floor of metamorphic rocks. These borings should also be used for water-pressure tests in order to determine the permeability.

\section{Conclusions}

28.41 It is suggested that alignment 2 in the Tangi Saidan Gorge may be the most suitable for the construction of a dam. The abutments consist mainly of Diabase and Hornblende Gabbro, and it is possible that similar rook is present concealed below talus and alluvium. The presence of a river fault is suspected.

28.42 The saddle between the villages of Lalander and Chehl Dokhteran consists of mainly uncemented gravels, which possibly possess a moderate permeability. The saddle would be unsuitable as a spillway.

28.43 The main dam would probably have to be constructed of concrete, with a spillsection. The saddle would have to be blocked by an earth-fill dyke.

28.44 The maximum economic height for the main dam is probably $60 \mathrm{~m}$. above present river level, with construction of two small dykes on the saddle. Any dam higher than $60 \mathrm{~m}$. would involve the construction of a costly earth dam upon the saddle. 
REPORT ON THE GEOLOGY OF TANGI SAIDAN

(Gorge on the Kabul River West of Rishkor)

by J.P. Hunger,

Mineralogist, U.N.T.A.B.,

Kabul.

(Translated from the German text: Report dated 5.6 .63 , but received by the $\mathbb{F} . \Lambda .0$ in Rome in March 1964)

28.45 The detalled mapping of the area covered by the new topographioal map was oarrled out during the middle of May 1963. The following notes are oomplementary to the geological map.

Roak Aroups

28.46 The lowest rooks cropping out in the gorge comprise predominantly an epi- to meso-metamorphio sonistose series of sedimentary origin, which consists of the following types:-

\author{
quartzose mioa schist \\ black sericitio roofing slates \\ quartzite \\ thin-bedded to limestone marmor, which \\ locally grades into dolomitic marmor.
}

28.47 These sedimentary metamorphic rocks are intruded by clearly defined basio areenstones of magmatio origin. They form intrusive bodies (slightly sohistose hornblende-diorite), are marginally strongly affected by tectonio stresses and rendered sohistose (hornblende-chlorite schist, chlorite-epidote schist, greenstone brecoia). Smaller masses of basic rook ocour in the form of lenses, become sohistose and broken, and have an appearance resembling Diabase. The following types are separated on the map:-

\author{
Diabase-brecoia \\ Diabase schist \\ Massive hornblende-Diorite ranging to gabbro.
}

The rocks have only been studied macroscopically. A mioroscopic study, as well as analytical determinations, yet remain to be undertaken.

28.48 Above the formations already described comes a bed of conglomeratio serioitio schist, strongly affected by dislocations metamorphism. Looally a kyanite rook is found as a stress indicator. The next formation consists of a platy thin-bedded limestone marmor with conglomeratio inclusions. In the upper part of this mass oocur irregular masses of reef-like dolomite. Two types are distinguished on the map:-

Platy limestone (carrying coral fossils)

Reef-dolomite. 
28.49 The age of these beds is not known. The Platy limestone and Reef-dolomite may belong to the Carboniferous, while the formations (1isted in paragraph 28.46) would oonsequently be pre-Carboniferous. The schistose intrusive rocks would lie between the two in geological time.

Tectonic and Related Technical Considerations

28.50 The rooks are intensively folded. The fold axes are indicated on the geological map. They plunge in general steeply towards the south-west, hence upstream. Faults and fractures are numerous, and are in part sealed. A vertical mylonite occurs on the right bank at the lower end of the gorge (this is stated in the text as having been shown on the map, but in fact no mylonite is indicateds it is presumed that the mylonite may be the same as the injeotion melange mentioned in para raph 28.13 no microscopic study has been made of any of the rocks in the gor $\mathrm{B}^{\mathrm{e}}$, and the exact petroeraphic description must await microscopic diagnosis: J.B. Auden). Mylonite, fault planes and fractures must be grouted in order to be rendered water-tight. The overthrust and other planes of movement dip W.S.W., and hence upstream, which is a favourable disposition in regard to dam design.

28.51 The travertine deposit. (calc-tufa) point to the aotivity of springs. The spring water arises at the intersection of planes of thrusting or disturbance with fractures. Test borings must be undertaken in such places in order to determine the intensity of flow. In addition to finding the quantity of discharge, the quality of the water must also be observed on account of possible solution effects on the oonorete.

28.52 The structural strengths of the schists, conglomeratio schists and greenstones are small, (see oomment in paragraph 28.56 below).

Dam Sites

28.53 Three possible dam sites were selected quite early in the investigation.

No. 1 Site Lowest alignment a little to the west of the water gauge constructed by the German Hydrological Mission.

Advantaces:- narrowest valley section; maximum possibility of reservoir storages relatively free from gravel and sand in the river bed.

Disadvantages:- The Greenstones have been stronfly affected by tectonic stresses and therefore lack strength: they will have to be excavated to a depth of some metres which will involve high stripping costs; grouting will be necessary. The sheared mylonite on the south side of the valley must be rendered water-tight.

No. 2 Site Middle dam site.

Advantages:- Rock spurs are present on both sides of the valley: the valley bottom under alluvial cover is relatively narrow. 
Disadvantares:- The rocks are locally rendered strongly schistose, dipping, however, inwards towards the valley; the contact between the Greenstones and the sohistose series has little strength, here also it will be necessary to remove a thick surface layer in order to reach fresh rocks remains of a travertine cover are present in the valley bottom, pointing to the activity of springs.

\section{No. 3 Site Upper Dam Site}

Advantages:- Both valley sides stand up as steep buttresses and comprise Platy limestones and dolomites, which are more stable: open fractures and joints can be easily rendered water-tight by grouting.

Disadvantages:- Largest valley cross section: valley bottom with deep alluvial deposits: the planes of movement between the underlying schistose series and the overlying limestone/dolomite lie cuvered with valley-bottom gravels, and mast be disclosed by test boring: the large travertine deposit (calo-tufa) in the valley bottom must be further studied, spring water must be located and diverted: on the south side of the valley the limestones tend towards inversion and must undergo a considerable amount of excavation.

28.54 The foundation rock of all three dam sites must be rendered water-tight by grouting.

28.55 The valley opens out behind the gorge into a capacious basin. On 1ts south side a low saddle leads southwards towards the Logar valley. Only slight compacted conglomerates and sand layers of the Lataband series orop out on this saddle. It will be necessary to determine the thickness of these relatively permeable beds upon the Crystalline foundation. They could result in leakage and the lowering of the effective reservoir surface!

(End of J.P. Hunger's Report)

Comment by J.B. Auden

28.56 In regard to paragraph 28.52 , J.P. Hunger's original reads "Die Verbandsfestigkeit der Sohiefer, konglomeratischen Schiefer und der Gruengesteine iat gering". It is not quite, clear if the author is referring to the crushing strengths of the individual rock types, which might perhaps have been expressed as "Druckfestigkeit", or to the weak planes of junction between the rock types where they are in juxtaposition. If, as is anticipated, but certainly not yet proved, basic intrusive rock ocoupies the valley floor, below river gravels, alone alignment 2 of paragraphs 28.28 and 28.31 , it is not thought that these rocks are so weak that they oannot support a concrete structure. 
PART VI - GROUND-WATER CONDITIONS IN KATAWAZ

\section{CONTENTS}

Chapter 29 GEOLOGICAL RECONNAISSANCE REPORT ON GROUND-WATER CONDITIONS IN KATAWAZ, AFOHANISTAN

$1-85$
1
7
23
46
51
55
66
73

Map

Map 19 Preliminary Geological Map of a Part of Katawaz, Ghazni Province 
GHAPTER 29 - GLOLOCICAL RECONNAISSANCE RETORT ON GROUND-WATER CONDIT IONS IN KATAWAZ, AFGHANISTAN

(Map 19)

1. Introduction

\section{Objeot of Investigation}

29.1 The Government of Afghanistan proposes if possible to settle nomads in parts of Katawaz, south of Ghazni. For this purpose it is necessary to assess the possibilities of ground-water development. The present report concerns a visit lasting two weoks made in the Nahar (Paltu) Valley during September 1962. The writer was accompanied by Messrs. Abdul Rauf and Lal Mohammad.

\section{Looation}

29.2 The area visited extends from the Ab-i-Istada in a north-east direotion to Yusuf Khel, both sides of the Nahar valley being studied. Excursions were also made to the Aoband and Nani areas, and southwards to the north side of the Wazikhwa plain. The two camps were at Kushaman (32041':68014'), formerly known as Adin Khel, and at Zarghun Shah (32051': 68027').

Photographs and Maps

29.3 Fairohild air photographs, strips 31-B to 34, were available together with advance copies of the Fairchild topographical sheets of part of Degree Sheet 521, on the soale of $1: 50,000$. The preliminary geologioal map which accompanies this report is based on a study of the air photographs, and the use of the excellent topographical sheets, as well as on traverses through the country. No maps were available between longitudes $68^{\circ} 45^{\prime}$ and $69^{\circ} 00^{\prime}$.

\section{Previous Work}

29.4 In 1955 various reports were prepared on the Dil Project (named after Dila village $32^{\circ} 36^{\prime}$, 68002'). The F.A.O. of U.N. made a preliminary soil study dated March 1955, while Dr. H. Furrer, at that time U.N. Geological Adviser to the Government of Afghanistan, prepared a report accompanied by a geologioal map dated 6.3.55 of the area between Adin Khel and Mukur, on the scale of $1: 253,440$.

E. Furrer's report was not available, but a copy of his map exists. During the last few years the German Geological Mission in Afghanistan has also been working in the region south of Ghazni. Both the F.A.O. report, and it seems H. Furrer, made reoommendations regarding further investigations in the region, but no action was taken.

29.5 In July $1962 \mathrm{Mr}$. Lenk Chevitz made a reconnaissance of the Katawaz area and suggested that the Nahar Valley should be selected as the site for nomad settlement. His map, which was not available when the writer visited Katawaz, has been extended by the Ministry of Agriculture, into a larger map that shows the division of the region into 4 sub-areas according to priority of further investigation. On this map open wells have been demarcated. The map is of value in having the wells, but, being based on the old Survey of India Quarter-Inch reconnaissance topo-sheets, it

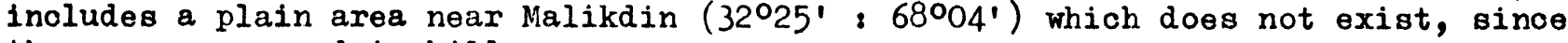
the area concerned is hilly. 
29.6 Finally, V.S. Subramanian, K. N. Satyapal and R.G. Menon made a reconnaissanct soil study of the area in July 1962. Mr. Subramanian oonoluded that in certain instances the use of irrigation water has rendered the soil more saline than when in a fallow condition.

\section{Aoknowledgement}

29.7 The thanks of the U.N. Speoial Fund team are due to Mr. E.O. Dahle and Mr. D. Yakubi, of the Offico of Mapping and Aerial Photography, Afghan Geologioal Survey, for much assistance offered in connection with the aerial photographs and advance copies of the maps.

\section{Topography, Precipitation, Run-Off}

\section{Topography}

29.8 The Nahar Valley is a wide flat valley running NE-SW from Yusuf Khel to the $\mathrm{Ab}-\mathrm{i}$-Istada. It is fed by minor streams coming in from the north-west and southeast, and a major tributary (perhaps the Nahar itself) flows north from the Woomna upland basin to join the main valley opposite Yusuf Khel. Woomna is the same village as "Omna" shown at $32^{\circ} 48^{\prime}$ ' $68^{\circ} 50^{\prime}$ ' on the 1 million aeronautical sheet at the head of the Gomal river, but the correct coordinates are not yet known, and the Woomna catchment definitely forms part of the Nahar drainage, and not that of the Gomal.

29.9 The Ab-i-Istada is given a height of $1968 \mathrm{~m}$. on the new maps. Yusuf Khel is probably at $2200 \mathrm{~m}$. but the maps do not extend that far. The overall gradient of the Thalweg is of the order of $1: 350$, but the flanks of the valley have gradients of $1: 40$ to $1: 150$.

29.10 The hills bordering the valley are for the most part gentle and rolling. An exception is in the steep scarp face which exists E.S.E. of Mest $\left(32^{\circ} 58^{\prime}: 68^{\circ} 33^{\prime}\right)$ where the hills rise to an elevation of $3300 \mathrm{~m}$. The Noomna basin is geologically a flat synoline, and has an elevation of $2500 \mathrm{~m}$.

\section{Preoipitation}

29.11 No data are available about precipitation in this region. The preoipitation may be of the order of 250-300 mm. per anmum, but the variation is likely to be large. The average annual rainfall of Fort Sandeman and Hindubagh in West Pakistan is as follows:-

\section{Elevation}

$1410 \mathrm{~m}$.

Fort Sandeman

Hindubagh

\section{Precipitation}

$274 \mathrm{~mm}$. $242 \mathrm{~mm}$.
Distance from Zarghun Shah

$193 \mathrm{Km}$.

$235 \mathrm{Km}$.

29.12 Some of the precipitation occurs as snow. At Kushaman the snow fall is said to average about $10 \mathrm{~cm}$. Over the Woomna basin the looal people indicated that $50 \mathrm{~cm}$. is about average. 


\section{Vegetation}

29.13 The greater part of the area is devoid of trees, and shows only a fair abundance of small shrubs seldom greater than $60 \mathrm{~cm}$. in height. Trees are normally only present in the valleys in places irrigated by karezes.

29.14 A marked exception exists, however, in the higher hills, of 2600 to $3300 \mathrm{~m}$. elevation bordering the Woomna basin east of Zargun Shah and E. S.E. of Mest. Air photographs in strips 34-A/1729-1730, 34-A.1/12326-12328, demonstrate the relative abundance of trees in this limited area. The trees are probably oak. There is a considerable export of timber and charcoal from the area, the village of Yahia Khel being a depot.

29.15 It may be questioned if there is any control of tree felling in this area. It would be unfortunate if even the few remaining hills that are forested are allowed to be deforested within a few yeare time.

Run-Off

29.16 Run-off in most areas should not be too rapid owing to the prevalent gentle hills slopes. Since the terrain on the south-east side of the valley shows outcrops of predominant Flysch shales, the Infiltration Capacity of the ground should be small, and such precipitation as occurs should largely find its was down to the tributary streams of the Nahar.

29.17 The Infiltration Capaoity of the Mio-Pliocene sandstones and conglomerates on the north-west side of the valley may be considerable. As will be discussed later, these formations dip to the north-west, away from the valley, and some proportion of the precipitation may be lost into the permeable sandstones and conglomerates, and diverted by structural disposition away from the Nahar Valley.

River Flow

29.18 The Nahar River, and its tributaries, were dry at the time of visit in September 1962. There are zones in the Nahar upstream of Loikhel $\left(32^{\circ} 39^{\prime}: 68^{\circ} 1^{\prime}\right.$ ) where the river sands are saturated to the surface, but no contimous surface flow was present along the river.

Discharges of the Gomal

29.19 In view of the scarcity of data concerning rainfall and run-off in the Katawaz area, particulars may be given concerning the run-off of the domal River for the 25-year period 1929-1953 incl. past the Murtaza gauge (32009' : 70005') in West Pakistan, the catchment area of which is $31,800 \mathrm{Km}^{2}$. It is true that the Gomal river at Murtaza includes the important tributaries of the Kundar and Zhob rivers, which rise in the hilly area south of Wazikhwa, but the variations of the Gomal at Murtaza may be accepted as representative of those which are likely to be expected at the Gomal headwaters in Afghanistan and the Nahar (Paltu) river which rises near the Gomal headwaters. The discharge figures must also have a close relationship with variations in precipitation.

29.20 The average anmual discharge of the Gomal at Murtaza throughout the 25-year period was 390,100 acre-feet, equivalent to $481,400,000 \mathrm{~m}$. The following are averages for consecutive years for high and low discharge:- 


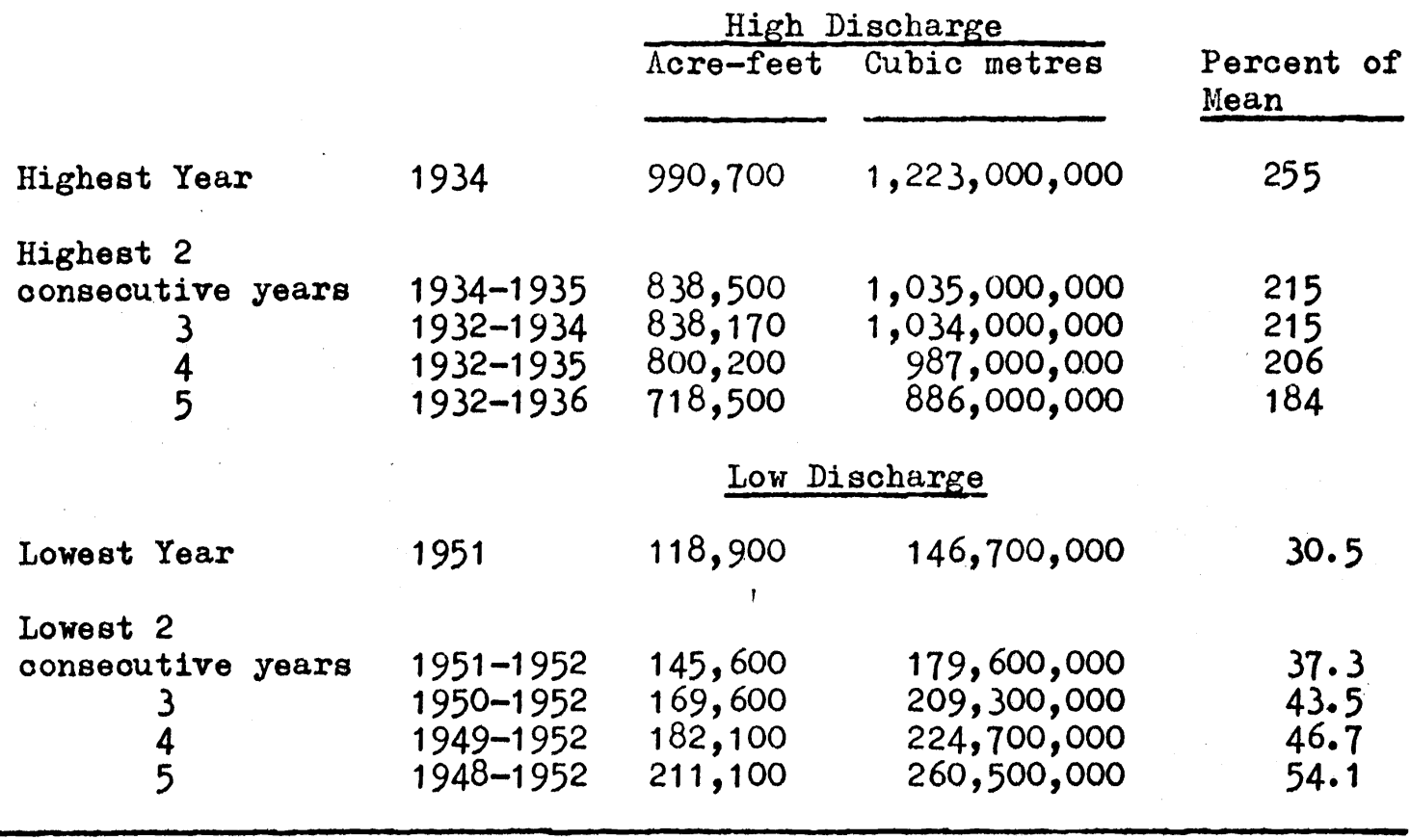

29.21 The above table emphasises the variability of the Gomal discharge which lies between $255 \%$ and $30.5 \%$ of the mean. For five consecutive years the discharge may average virtually only half of the mean. Since the base period of 25 years inoludes discharges that are so widely divergent, it may be assumed to be moderately representative. The mean discharge over the Gomal oatohment of $31,800 \mathrm{Km}^{2}$ upstream of the Murtaza gauge is $15,100 \mathrm{~m} 3 / \mathrm{Km}^{2}$, while the specific discharge is $0.48 \mathrm{litres} / \mathrm{sec} /$ $\mathrm{Km}^{2}$. This low mean specific discharge may be compared with those of the Kabul river. At the German Tangi Guru gauge the specific discharge averaged 1.4 litres/ $\mathrm{sec} / \mathrm{Km}^{2}$ for the three water years 1959/60 to 1961/62, while the same river at Warsak, after it has received glacier-fed tributaries, has a specific disoharge of the order of $7-9$ litres/sec/ $\mathrm{Km}^{2}$.

29.22 Most of the Gomal catchment is located on rocks of Flysoh type, and in a geological sense the infiltration characteristios of the smaller terrain of the Gomal and Nahar headwaters may be regarded as similar to those of the full catchment at Murtaza. On the other hand, the Nahar and upper Gomal rise in high terrain, over $2,000 \mathrm{~m}$. in elevation, where snow must lie for $2-3$ months in the year, and it is probable that the run-off per square kilometre of catchment in the Nahar and upper Gomal will be somewhat higher than the average run-off for the much larger catchment down as far as the Murtaza gauge. The Gomal at Nurtaza never, however, ceases to flow, while the Nahar is dry for several months in the year.

\section{Geological Framework}

29.23 The following is the geological sequence in the Nahar valley area, but it must be pointed out that on account of the past tectonic history and periods of erosion, the succession is a composite one, arranged in the inferred geological succession, but without the contacts between units necessary to establish the true relationships. 
Inferred Age

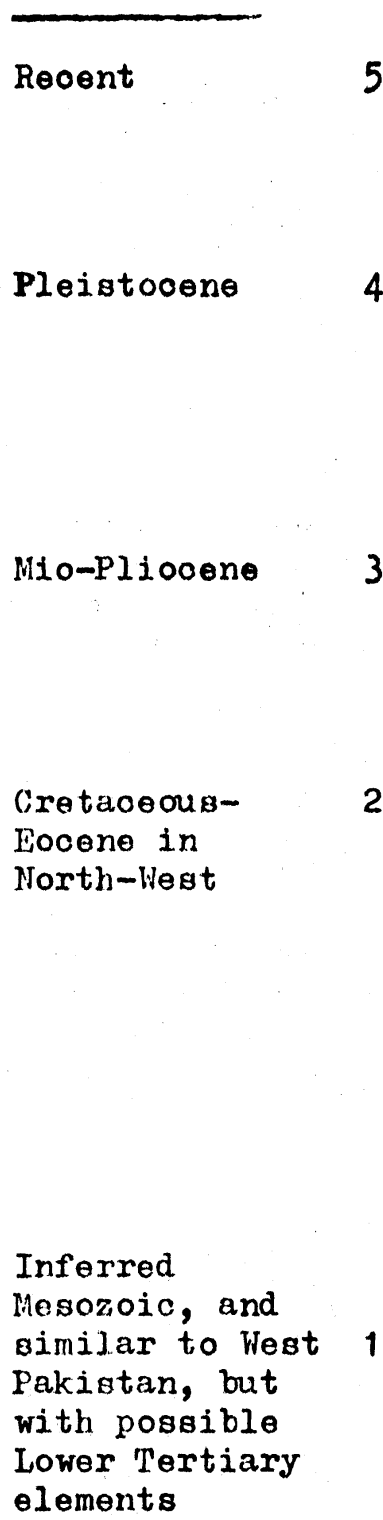

Formation

5 River alluvium, wind blown sand, Loess

r w r r ara on sides of valley

$4 \quad$ Clays with a capping of Terrace Gravels

นกนกนกนก

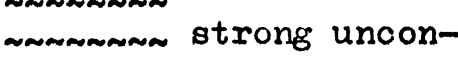
formity

3 Conglomerates, sandstones, silts and clays

น น น น น น

น น น น น น

2 Sandstones and Shales, Eocene Limestone, Volcanics. Seen in different looalities in north-west but not in contact with each other or with formations 1 and 3 .

น น น น น

น น น บนก

Flysch: predominant calcareous shales, and shales, some with fracture cleavage, together with thick and thin beds of cemented calcareous sandstone, containiné quartz, calcite, and quartz + caloite veins. Present south-east side of Nahar valley, and no contact seen with formations 2 and 3.
Earth Movements

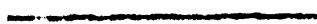

tilting and erosion

Over $100 \mathrm{~m}$.

strone folding and erosion alone N. E. -S.W. axes

not lese than $2,000 \mathrm{~m}$.

strong folding and erosion

strong folding alone NNE-SSW axes, possibly earlier than the folding of formation 2 .
Approximate thickness in metres several $1,000 \mathrm{~m}$. 
Lithology and Disposition

\section{Flysch}

29.24 The Flysch consists of a great thickness of grey shales and oalcareous shales interbedded with beds of cemented calcareous sandstone. Over most of the area the shales form about 70 percent of the observed thickness, but in the cliffs of the range east of Zarghun Shah the relative proportions of shale and sandstone may be about $40: 60$. The shales have fracture cleavage while the sandstones are strongly jointed. Neither shales nor sandstone bave matrix porosity, but water must be held by the joints in the sandstones where these are open near ground surface.

29.25 The Flysch is disposed in tight and more open folds, some of great axial length, and the folds strike N.N.E.-S.S.W. obliquely into the Nahar Velley which is aligned N.E.-S.W.. Flysch occupies all the hill area on the south-east side of the valley, as far south as the north edge' of the Wazikhe plain, which was visited at coordinates $32^{\circ} 17^{\prime}: 68^{\circ} 18^{\prime}$. It extends almost certainly southwards beyond this point. From the Woomna pass the Flysch was seen to ocour in broad folds across the valley for a distance of about $12 \mathrm{~km}$. and Flysch probably forms the strong folds of air stri.ps $34-\mathrm{A}-2,34-\mathrm{A}-3$ and $34-\mathrm{A}-4$ in Photo Index map 3369.

29.26 The Flysch is not seen in contact with formations 2 and 3 of the tabulated succession given above, and it is not known if formerly the thick Mio-Pliocene succession may have extended to the south-east over the top of the extensive Flysoh outcrop, and was later eroded away.

29.27 All that is apparent is that Flysch forms the south-eastern side of the Nahar Valley, while Mio-Pliocene is present on the north-west side. Both the Flysch and the Mio-Pliocene are unconformably overlain by Terrace Gravels and clays. It appears to be very probable that the Flysch extends below the Nahar alluvium and forms the "basement" of the valley.

Eocene \& Cretaceous

29.28 Isolated outcrops of Eocene limestones, somewhat flysch-like shales and sandstones, and voloanios occur in the area just south and north-west of Bedi $\left(32^{\circ} 58^{\prime}\right.$. $68^{\circ} 21^{\prime}$ but the relationships, both between these formations, and with the MioPliocene, are obscure. The narrow highly folded outcrops of Eocene Limestone, such as that on hill $2447 \mathrm{~m}$. $\left(32^{\circ} 59^{\prime}: 68^{\circ} 6^{\prime}\right)$, certainly do not continue at depth towards the south-east to form a limestone basement below the Nahar River. These limestones therefore have no significance from the point of view of ground-water distribution below the Nahar Valley.

\section{Mio-Pliocene}

29.29 The rocks described in this section as Mio-Pliocene resemble the Siwaliks of India and Pakistan, but there is no direct fossil proof that they fall within the period of time indicated by Miocene and Pliocene. A thick succession of oonglomerates, sandstones, silts and clays occurs in the form of a pronounced syncline north-west of Zarghun Shah. The axis is $8.5 \mathrm{Km}$. W.N.W. of the fort. Beyond the synoline is an anticline, the north-west limb of which has been truncated by an east-west fault. The south-east limb of the syncline has dips varying between $40^{\circ}$ and $50^{\circ}$ over a horizontal extent of $2.5 \mathrm{Km}$. but the dips flatten out at the axis. The minimum thickness of beds cannot be less than 2200 metres, and may approach 
3,000 metres. The succession along the south-west limb of the syncline is well exposed on the traok 4.5 to $7.5 \mathrm{Km}$. north-west of Zarghun Shah fort towards Bedi (32058': 68021') but the other limb is not clearly manifest on this route although it is magnificently displayed in another part of the fold in air photograph 33-7546.

29.30 Between the clear outcrops of Mio-Pliocene and Zarghun Shah, and forming isolated ridges between Zarghun Shah, Saighana and Mest (32058': $68^{\circ} 33^{\prime}$ ), there are outcrops of conglomerates, sandstones and shales with strong dips which are almost completely covered by flatlying clays and Terrace Gravels. It is presumed that the steeply dipping beds seen near the road on the south side of Mest village, at Yusuf Khel village, and 3.5-4.0 Km. N.N.E. Zarghun Shah fort, belong also to the Mio-Pliocene. At every isolated outcrop except one which was seen the beds dip to the west, W.N.W. or N.W., and if they form part of a normal undisturbed succession with the well exposed beds that lie further north-west, the true thickness of the inferred Mio-Pliocene will be over $4,000 \mathrm{~m}$. It is possible however that the poorly exposed beds, mainly submerged below Terrace Gravels, may form part of another fold, faulted against the one described in para. 29 above.

29.31 The sandstones and conclomerates are usually without calcareous cement, but some of the sandstones show zones of nodules which are calcified portions of the more usual soft uncemented sandstone. The Mio-Pliocene sandstones should have a high infiltration capacity, and should be good aquifers. In India and Pakistan the Siwalik waters are however frequently saline.

29.32 Since these sandstones almost without exception have dips towards the west, W.N.W. and north-west, away from the Nahar valley, their disposition is such that water penetrating them will migrate down-dip and not towards the main part of the valley. The sandstone members must be confined aquifers and there is a potential artesian condition within the syncline, located some $15 \mathrm{~km}$. north-west of the Nahar river.

29.33 The axis of the syncline has, however, a culmination in such manner that the fold pitches both E.N.E. and W.S.W. The pitch towards the W.S.W. is well developed in map $521 \mathrm{~A} / 2$ near coordinates $32^{\circ} 52^{\prime}$ : $68^{\circ} 19^{\prime}$, and should result in the movement of the confined water within the syncline towards the lower part of the Nahar and Ghazni valleys. The inlier of Mio-Pliocene in map No. $521 \mathrm{~A} / 4$ near coordinates $32^{\circ} 46^{\prime}$ : $68^{\circ} 17^{\prime}$ probably has north-west dips, so that there can be no migration of confined water directly southwards into the part of the Nahar valley where development is likely to take place.

\section{Pleistocene}

29.34 The Terrace Gravels and Clays were originally classified as late Siwalik when work was being carried out from Kushaman. On seeing the large inlier of strongly folded and more typical Siwalik rocks which is present north-west of Zarghun Shah in map $521 \mathrm{~A} / 2$, unconformably overlain by Terrace Gravels and Clays, it became necessary to separate the only slightly tilted younger beds from the folded MioPliocene, and to place them in the Pleistocene.

29. 35 Gravels form the capping to the slightly tilted plateaux on both sides of the Nahar valley, overlying a group of clays. The beds are best exposed in map $521 \mathrm{c} / 2$, where they are present on hills 2169,2173 and 2184 (32038': 68028'), and possess a gentle N.N.W. dip of the order of $1^{\circ}$ or 1:57. The lower part of the scarps are occupied by clays. At hill 2184 the thickness of these gravels and clays is not less than $105 \mathrm{~m}$. 
29.36 Gravels, sandstones and clays are well exposed between Kushaman and Ushli around hill $2076\left(32^{\circ} 44^{\prime}: 68^{\circ} 10^{\prime}\right)$, where they give the impression of a very gentle dip towards the S.S.E. In this area there are anonalous erratics of Eocene Limestone within the gravels. It was thought at first that there might be inliers of early Tertiary that had escaped complete submergence below, the Pleistocene cover, but some of the small limestone outcrops, up to about $50 \mathrm{~m}^{3}$ in volume, have exactly the appearance of erratics floatine on the gravels, and it is possible that they were brought down to their present position during the late pleistocene when the higher ranges may have had a covering of ice.

29.37 The Pleistocene almost covers the outer group of inferred Mio-Pliocene represented by narrow ridges which are exposed between Zarghun Shah, Saighana, Meat and Yusuf Khel. These show steeply dipping conglomerates and sandstones and olays under a cover of gravels.

29. 38 An important inlier of gravels, 'stioking up out of alluvium, is present in the group of miniature hills in map $521 \mathrm{C} / 1$, near coordinates $32^{\circ} 35^{\prime}: 68^{\circ} 081^{\prime}$, between Dila and Minaure. This outcrop is significant since it indicates that the Pleistocene gravels and clays are probably present below alluvium throughout the extent of the Nahar valley.

29.39 On the south-east side of the Nahar valley the Pleistocene gravels and clays have been cut into by tributary streams flowing into the Nahar, which is probably a result of the tilt that has been imposed on these beds. Consequently, the recent alluvium shows an unconformity against elevated and dissected gravels and clays. In this area, therefore, the Pleistocene gravels are not contimuous. It appears probable, however, that this unconformity is local and confined to the south-east side of the valley, while towards the axis of the valley it is probable that the alluvium rests on uneroded gravels and clays.

29.40 In Eeneral, therefore, we may expect the Pleistocene gravels and clays to be contimuous below alluvium along the main part of the Nahar valley. Consequently, there should be a moderately widespread gravel aquifer of Pleistocene age below the Nahar alluvium in the axial zone of the valley.

\section{Alluvium}

29.41 The alluvium occupies the centre of the Nahar valley, and is a composite formation, mainly fluviatile, but partly composed of wind-blown loess-like material, and wind-blown dune sand. The sequence of beds in the bottom 7.7 metres of the Juari well $\left(32^{\circ} 50^{\prime}: 68^{\circ} 29^{\prime}\right)$ is as follows:

10 metres to ground level

$$
\begin{aligned}
& 1.30 \mathrm{~m} \\
& 1.45 \\
& 0.25 \\
& 1.60 \\
& 0.80 \\
& 1.00 \\
& 1.30
\end{aligned}
$$

silty sand

silt

clean medium-grained sand silty sand with pebbles medium to coarse sand with cravel up to $5 \mathrm{~mm}$. in diameter coarse sand with $10 \mathrm{~mm}$. pebbles very fine sand, within the ground-water zone. 
29.42 The upper beds of alluvium, where exposed along the river banks, are more argillaceous, consisting of sandy silts, silts and clay-silts. Zones of saline efflorescences are present, such as that well displayed at a depth of $2.60 \mathrm{~m}$. below ground surface in the Kushaman (Loikhela) well.

29.43 In the open wells which were visited, all of which are in the axial zone adjacent to the Nahar river, the water table varied from 5.8-7.0 m. below ground surface in the Kushaman-Musa area, and 15.6-17.6 m. below ground surface east of Zarghun Shah.

29.44 The Kushaman (Loikhela) well is close to the Nahar river, which is in that area incised into its own alluvium to a depth of $3.4 \mathrm{~m}$. The water table in this well is $6.80 \mathrm{~m}$. below ground surface, and thus $3.4 \mathrm{~m}$. below river-bed level. This disposition indicates that, when water does flow in the Nahar river, the relationship of the river to the water table in Influent.

29.45 The thickness of the alluvium is not known. It may be of the order of $200 \mathrm{~m}$. alone the centre of the valley, but this is a guess.

\section{Summary of Aquifer Distribution}

29.46 Flysch ocoupies the south-east side of the Nahar valley, and is probably the "basement" to the valley itself, under a cover of Pleistocene and Alluvium. The predominantly argillaceous nature of the Flysch, and the fact that the sandstone members are cemented, indicates that this formation has a low infiltration capacity. The structural grain of the tightly folded Flysch is oblique to the axis of the valley. It is not recommended that any boring for water should be undertaken into the Flysch "basement".

29.47 The Eocene limestones are located along a zone $26 \mathrm{~km}$. to the north-west of the area, and have no sub-surface extension towards the Nahar.

29.48 The Mio-Pliocene which forms the north-west flank of the Nahar valley has potential aquifers, but the disposition of the strata is such that water penetrating into the sandstones and conglomerates would be diverted away from the valley towards the syncline. This syncline has a culmination, with reversal of pitch, and was seriously eroded before deposition of the Pleistocene. Artesian conditions would therefore be poorly developed within this syncline. The ground-water in the MioPliocene probably has a moderately high salinity.

29.49 The principal aquifers of the Nahar area are considered to be in the Pleistocene gravels and the overlying Alluvium. The combined thickness of the Pleistocene gravels and Alluvium must vary considerably depending on factors of local erosion and wash-outs. As an approximation it is possible that the maximum thickness of Pleistocene and Alluvium, along the axis of the valley, may be $300 \mathrm{~m}$. Since, however, clays form an important part of the Pleistocene, lying below the gravels, the potential thickness of aquifer formations may not greatly exceed $200 \mathrm{~m}$. Aotual drilling would be required in order to obtain accurate figures.

29.50 It is understood that the possibility of deep artesian aquifers in the Dila area had been considered in 1955 by Dr. H. Furrer. In the writer's opinion, it would appear to be most improbable that artesian aquifers are present at depth along the Nahar valley, since tightly folded Flysch almost certainly forms the floor to the valley at quite a shallow depth below Pleistocene clays and gravels. The only area in the Flysch outcrop which might have artesian conditions is in the upland Woomna basin, to the east of the mountains which form the south-east flank of the 
valley due east of Zarghun Shah where the folds are of a much broader nature. Even here, however, the lithological nature of the Flysoh is ouoh that good aquifers are absent.

\section{Water Salinity}

29.51 Eight samples of Karez and well water were colleoted for analysis. Unfortunately, the well of the Ministry of Agriculture, Kabul, went dry, and it was impossible for Dr. K.N. Satyapal, Soil Chemist of the U.N.S.F. team, to undertake full analyses. However, he was able to determine pH by the glass-electrode Beokman pH metre, total salts by means of conductivity measurements using the standard Solu Bridge, and Sodium and Potassium by means of the Lange Flame Photometer. The following are the results of the determinations undertaken by Dr. K.N. Satyapal. All samples were colleoted in Septernier 1962 :

$$
\begin{aligned}
& \text { pH' Total Salts Na K } \\
& \text { - p.p.m. p.p.m. p.p.m. }
\end{aligned}
$$

Wello Waterg

Musa Well

Kushaman Well

Juari Well.

$\begin{array}{llr}32^{\circ} 37^{\prime}: 68^{\circ} 05^{\prime} & 7.8 & 3840 \\ 32^{\circ} 40^{\prime}: 68^{\circ} 15^{\prime} & 7.7 & 1792 \\ 32^{\circ} 50^{\prime}: 68^{\circ} 29^{\prime} & 7.7 & 672\end{array}$

900

400

110
15

7

Karez Waters

\begin{tabular}{lllrrr} 
Ushlan & $32^{\circ} 46^{\prime}: 68^{\circ} 09^{\prime}$ & 7.4 & 2112 & 600 & 10 \\
Wazikhwa- & $32^{\circ} 14^{\prime}: 68^{\circ} 19^{\prime}$ & 7.5 & 832 & 150 & 4.5 \\
$\quad$ Mushulie & $32^{\circ} 52^{\prime}: 68^{\circ} 31^{\prime}$ & 7.7 & 576 & 120 & 3.5 \\
$\begin{array}{l}\text { Painda } \\
\text { Zarghun Shah }\end{array}$ & $32^{\circ} 27^{\prime}: 68^{\circ} 51^{\prime}$ & 7.2 & 448 & 100 & 5.5 \\
\hline Lake Water & & 9.6 & 71680 & 30000 & 300 \\
\hline Ab-i-lotada & & 9.6 & & & \\
\hline
\end{tabular}

29.52 The Musa well, which was sampled at a time of active sanat-pumping, was manifestly very saline to the taste. It is seen to have a total salinity of 3840 , and this concentration must be regarded as representative. Water was not being extracted from the Kushaman well, and its total salinity of 1792 p.p.m. is possibly not typical of the ground water of that area when in active oirculation. One might expeot a salinity of the ground water in the Kushaman area of around $1000 \mathrm{p} . \mathrm{p} . \mathrm{m}$. The Juari well was under active pumping, and the salinity of $672 \mathrm{p.p.m}$. may be regarded as representative for the ground water of the alluvial area around Zarghun Shah. There is a clear increase in salinity in the ground water from north-east towards the south-west.

29.53 of the Karez waters, that at Ushlan is out of the Nahar valley and is probably derived indirectly from the Mio-Pliocene rocks. Its high salinity is not typical of that of the karez waters on the upper Nahar valley itself. The Painda and Zarghun Shah karezes may be regarded as characteristic of the waters derived from the flanks of the Nahar valley, both being very suitable for irrigation. 
29.54 The water from the Ab-i-Istada has extremely high alkalinity, and it may be suspeoted that carbonates and bicarbonates are high. The concentration of this water at the time of sampling in September 1962 was roughly twice that of sea water. No doubt the concentration decreases on the infrequent occasions when flood water from the Ghazni and Nahar rivers reach the lake. The amount of potassium is only $1 \%$ that of sodium. Unfortunately, the failure of the laboratory water supply in Kabul has prevented further study of this interesting lake water, and it is impossible at present to compare it with inland waters of somewhat similar locations, such as Sambhar and Didwana in Rajasthan, India.

\section{Present Ground-Water Exploitation}

\section{$\underline{\text { Karezes }}$}

29.55 The development of karezes in the upper part of the Nahar valley is quite remarkable. The new topographical maps show the karezes with great clarity, and in an area of $20 \mathrm{Km}^{2}$ east of Kushaman the aggregate length of the karezes is $38 \mathrm{~km}$., or almost $2 \mathrm{Km}$. per square kilometre. The karezes are of the following main types:

(a) Karezes which take off directly from river bed gravels and intercept sub-surface stream flow:-

(i) Minsure $\left(32^{\circ} 31^{\prime}: 68^{\circ} 12^{\prime}\right)$. Length $6.75 \mathrm{Km}$. Depth of up-gradient shaft near intake $36.4 \mathrm{~m}$. Karez intake depth possibly $10 \mathrm{~m}$. below river-bed level. Yield approximately 2.9 litres/sec. +++

(ii) Malikdin $\left(32^{\circ} 25^{\prime}: 68^{\circ} 04^{\prime}\right) .2 \mathrm{Km}$. long: 38 Litres/sec.

(iii) Mest $\left(32^{\circ} 58^{\prime}: 68^{\circ} 33^{\prime}\right)$. Two karezes take off from the dry bed of the Mest tributary. The disoharge of the right-bank karez was 50 litres/sec on 16.9 .1961$.

(b) Karezes taking off down the alluvial cones deposited by the Saighana and Mest tributaries 5-6 Km. from their debouchures into the Nahar valley. The surface slope of these flat cones is $1: 120$ to $1: 150$, but the gradients of the karez tunnels is likely to be about $1: 300$.

(o) Karezes taking off from the flanks of the Nahar valley, particularly on the south-east side in map No. $521 \mathrm{~B} / 1$ where the up-gradient shafts start some $4-6 \mathrm{Km}$. north-west of the Pleistocene/Flysch boundary. The maximum surface gradient is about 1:140, but the karezes run diagonally to the maximum slope, and the component of surface slope in the direction of the karezes is about $1: 250$. The karez tunnels may have a gradient of $1: 300$ with up-gradient shafts of the order of 10-15 m. in depth. Many of these tunnels would appear to start at the intake end at an elevation of about $2130-2135 \mathrm{~m}$. a.s.1., possibly within Pleistocene gravels. A karez near Kushaman had a discharge of 11.6 litres/seo., while one at Painda yielded 4 litres/sec.

+++ Estimates of karez flow were made by obtaining the oross-sectional area of ohannels, determining the maximum surface velocity, and subsequently applying a $2 / 3$ factor to obtain mean velocity. 
29.56 It is impossible without detailed study to estimate the total discharge $t_{\alpha}$, m 'the karezes of the Nahar valley. Some karezes were dry at the time of viait, while the discharge of the running karezes obviously varies within wide limits. Leaving out the karezes which take off from river-gravel beds, and are intercepting the oub-surface stream flow, and considering only the karezes within the Nahar valley, there is an area of about $400 \mathrm{Km}^{2}$ in which the karezes are particularly well developed. If one assumes the existence of 400 karezes, with an average discharge of 5 litres per second, the total discharge would be 2,000 1/s., but such a figure is no more than a guess.

\section{Open Wells}

29.57 In a map on the scale of 1:253,440 which was prepared by the Ministry of Africulture, 16 open wells have been shown in the main Nahar valley, with depths ranging from 6 to $21 \mathrm{~m}$. Time did not permit of a visit to all the wells whioh are present, but representative wells were seen around Musa, by Kushaman-Loikhela, and near Zarghun Shah.

29.58 The Musa well waters are saline, one sample analysed by Dr. Satyapal having total salts of 3840 p.p.m. (paragraph 29.51 above). The wind-driven pump has been out of action for some years, but there are several active sanat wells. The water table is 5.6 to $7 \mathrm{~m}$. below ground surface which is at an elevation of about $1982 \mathrm{~m}$. Hence, the water table is at an elevation of about $1976 \mathrm{~m}$. The present level of the $\mathrm{Ab}$-i-Istada is given as $1968 \mathrm{~m}$, or 8 metres below the water table at Musa. Hence the salinity of the Musa ground water is not due to any sub-surface landward and influent extension of the lake water, but both the Musa salinity and the lake salinity must be due to common factors, which find their strongest expression in the remarkable salinity and alkalinity of the lake water itself.

29.59 The main development of diesel-driven contrifugal pumped wells is north-east of Loikhela $\left(32^{\circ} 39^{1 / 2} \mathrm{2}^{\prime}: 68^{\circ} 1^{\prime}\right)$. These wells are located within $2-3 \mathrm{Km}$. of the Nahar river, and show a progressive increase in depth of the water table below ground surface from $6.8 \mathrm{~m}$. near Loikhela to about $18 \mathrm{~m}$. south-east of Zarghun Shah.

29.60 The Juari water has total salts amounting to 672 p.p.m. Water salinities should be mainly below 1,000 p.p.m., and the majority of the water are probably class 1 .

29.61 No proper estimates of water discharge were made, but it appeared from the eye, that the discharge of the Juari and Amir Shah wells, south-east and east of Zarghun Shah, might be of the order of half a cubic foot per seoond or 14 litres/seo.

29.62 It is difficult to obtain reliable information from the well owners, but it appears that the Amir Shah well may be pumped for 1.5 hours when the draw-down reaches $2.60 \mathrm{~m}$., which is the end of the pipe below water-table level, and then requires 30 mimutes to recuperate. This would point to a somewhat low perneability coefficient, but the full thickness of the aquifer is not known, and it might be that with a longer intake pipe, if the aquifer exceeds $2.60 \mathrm{~m}$. in thickness, more prolonged pumping would be possible.

29.63 On the other hand, some of the diesel-driver pumped wells are stated to run throughout the 24 hours without the draw-down falling below the intake pipe. 
29.64 The aquifer sands would appear from eye inspection to have permeability coefficients as defined in the United States of between 300 and 1000 , equivalent to 1.22 to 4.07 l.p.d. $/ \mathrm{cm}^{2}$ with a $100 \%$ gradient, or say $4 \mathrm{~cm}^{3}$ to $12 \mathrm{~cm}^{3} / \mathrm{cm}^{2}$ per day with a gradient of $1: 300$. It is difficult to translate these figures into terns of discharge per day per given draw-down since the thicknesses of the aquifers are not known.

29.65 Some quantities of sand were brought up by the pumps in two of the wells which were seen, and according to one well owner, collapsed walls are frequent. In the case of a bored well, with strainer sections, it is probable that shrouding, or packing, with gravel round the strainer sections would be desirable in order to reduce entrance velocities, clogging up of the slots and collapse of the aquifer round the pipe.

\section{Conclusions}

29.66 It has been indicated that the aquifers of the Nahar valley are likely to be located mainly in the Pleistocene gravels and the alluvium-cum-loess, within a vertical thickness of possibly $200 \mathrm{~m}$.

29.67 The Nahar river was dry during September, except for patches of stagnant pools in the river gravels. The tributaries were dry, but sub-surface flow in the river gravels of the tributaries is tapped by karezes with quite considerable yields. The rivers are influent, their beds being at a considerably higher elevation than the water table.

29.68 It will be exceptionally difficult to determine the rate of re-charge from the surface streams, down to the water table, durine periods of actual flow, since the streams are wide, and the river channels are numerous. Stream-gauging will therefore be almost impossible except during periods of flood, when the quantity of water lost by influent seepage is likely to be only a small fraction of the total volume of flood discharge.

29.69 There is a considerable exploitation of ground water in the Nahar valley, both by karezes and by open wells. To what extent the withdrawal of ground-water can be increased by additional wells is difficult to state without further investigation. It is sound practice to withdraw as much ground-water as possible so as to allow re-charge from river sources which would otherwise have been discharged urutilised by surface flow out of the region. In this area, however, there is no surface flow for several months in the year, whioh suggests that there is in any case not much surplus water discharged without utilisation. It is not sound praotice, however, to withdraw more ground-water from storage than is replenished anmually into storaze from re-charge areas.

29.70 It is customary to use the term Safe Yield to indicate the yield which in any particular area would not result in withdrawal of ground-water from storage in excess of that which is added by re-charge to storage, but in practice this is a difficult concept to define without a great amount of data. It would be necessary on the one hand to have accurate measurements of the yields of all the karezes and wells, and of the quantities of influent seepage. It would be necessary also to make seasonal water-table maps to compare ground-water levels with areas of re-charge and of withdrawal from wells. Finally, the determination of permeability coefficients and specific capacities would be required by means of test wells with associated observation wells. These investigations will have to be undertaken in Katawaz, but they require time and personnel, and no early answer to the problem of Safe Yield can be expected. 
29.71 It would appear very probable that a considerably increased development of the ground-water resources in the Nahar valley will be possible, but it would be a mistake to give any optimistic target for the mumber of nomads which could be acoommodated in the area. The following points may be stressed:

(a) There are no meteorological data.

(b) Even the main Nahar is an intermittent stream.

(o) The south-western part of the area has saline ground-water, and salinity increases in the direction of the Ab-i-Istada. If excessive withdrawal of ground water, in the north-eastern part of the area which is likely to be developed, were to result in a reversal of water-table gradient, there might be an encroachment of saline water from the south-west.

(d) While the karezes usually take off from aquifers which are at a higher level than the level of ground water tapped by the wells, the relationship between the aquifers in the alluvium is not known. If there is a wedge-like interconnection between the aquifer sands, excessive withdrawal of water from wells might affect the intake of water to the karezes.

(e) The problem of using ground-water of varying salinity for purposes of irrigation does not come within the scope of this report. The report by V.S.Subramanian dated July 1962 indicates that near kushaman the surface soils where irrigated by poor quality water develop into saline-alkaline soils. That this phenomenon cannot hold everywhere in the Nahar valley is evident from the fact that cultivation of the area has been undertaken for centuries, without progressive deterioration and poisoning of the surface soil. But the problem clearly requires much further attention.

29.72 These uncertainties indicate the need for caution, and a gradual approach to the problem of nomad settlement. It is sugfested that development should be confined to the north-east side of an arbitrary line drawn through Churi village (32038', $680^{11}$ ) as shown on the map which accompanies this report. South-west of this line the ground-water becomes too saline for profitable use.

\section{Recommendations}

29.73 A meteorological station should be installed at Zarghun Shah.

29.74 A survey of the Karezes of the Nahar valley should be undertaken in order to obtain information concerning the total discharge. Representative karezes should be gauged seasonally in order to study fluctuations in discharge.

29.75 All existing wells should be located on the new 1:50,000 topographical sheets. Pumping discharges should be measured by a device such as a "V" notch. 


\section{Experimental Wells}

29.76 It will be necessary to sink 3 experimental tube wells so as to reach the base of the Pleistooene gravels and to $\mathrm{log}$ the aquifers which are encountered. The depths which will be required for these wells to reach the Pleistocene gravels are not known, but may be of the order of $200 \mathrm{~m}$. Pumping tests on the individual aquifers should be carried out, and the draw-down determined by means of observation wells. In this way it will be possible to determine permeability coeffioients. It is ouggested that one of these wells should be located on the south-east flank of the valley alone the zone from which the karezes start. The other two experimental wells should be alone the axis of the valley, one south-east of Zarghun Shah, and one near Loikhela.

\section{Automatio Water Stase Recorders}

29.77 Automatic water-stage recorders should be installed in 2 open wells that are not in use, so that a continuous record of fluctuations of the water table may be obtained.

Water-Table Contour liaps

29.78 It will be necessary to prepare periodic water-table maps in order to study variations in level of the water table in relation to pumping from wells and re-charge from streams. The contour interval of $25 \mathrm{~m}$. on the new topographioal sheets $i$ s rather wide for this purpose, since interpolation may lead to errors of the same magnitude as the probable variations in level of the ground water. It may be necessary therefore to have lines of levels between the existing contours in order to reduce the water table levels to a reliable datum. On account of the large development of karezes, and the relative paucity of wells, determination of the regional water table contours will be difficult until new wells have been sunk over a wider area.

29.79 It will be particularly important to keep a check on the disposition of the water table contours at the south-west end of the area, between Zaudhakhan and Churi, in case excessive lowering of the water table through heavy pumpine might result in a reversal of gradient, and encroachment of saline water from the southwest.

\section{Artificial Re-Charge}

29.80 It is premature at present to consider the question of water-spreadine in order to supplement re-charce. The following streams may, however, be considered as potential sites for temporary or permanent storage, and release of water a.t the heads of the apices of alluvial cones:

(a) Saighana: in the tangi, $103 \mathrm{~m}$. wide at river level, upstream of Saighana and aligned $215^{\circ}-35^{\circ}$. Right bank 1:2.5 slope, left bank 1:7 slope. Upstream gradient $1: 76$ approx. Abutments gently dipping conglomerates of probable Pleistocene age.

(b) Mest: in the tangi upstream of Mest village. River Eravels $133 \mathrm{~m}$. wide, but $230 \mathrm{~m}$. wide including colluvial slopes. An alignment $60^{\circ}-240^{\circ}$, sliehtly oblique to the axis of the valley. Banks slope at $1: 2.2$, and consist of Eently dipping conglomerates of probable Pleistocene age. 
(0) Woomna river where it debouches from the hills on the south-west side of the Nahar valley in air photographs $34-A-1 / 12331,34-a-2 / 7302$. Approx. $26 \mathrm{Km}$. E.N.E. of Mest and $16.5 \mathrm{Km}$. east of Yusuf $\mathrm{Khel}$. No map is available at present of this site. The site is located on an outcrop of Flysch sandstones and shales, striking NNE-SSW. The width between abutments, as measured from the 12 inch ( $30.5 \mathrm{~cm}$.) photography is about 125 metres. Dips are steep towards the WNW, or downstream. This site might take a $30 \mathrm{~m}$. masonry or concrete dam. The river gradient is not known but, in view of the rapid drop in levels from the Woomna basin to the Nahar valley, the gradient is likely to be steep, and storage volume may be small.

29.81 Water-spreading has long been developed in California. At the height of the water-spreading season January-April the volume of water spread into the apices of the alluvium cones in Ventura County, and the St. Gabriel River near Azuza, amounts to 1.0 to 3.5 cubic metres per second.

Well Improvement

29.82 Since some of the aquifers consist of fine sands, it will be advisable to insert gravel packing between the strainers of the tube wells and the walls of the boring. The purpose of this gravel envelope is twofold:-

to reduce entrance velocities of the water moving into the well

and to prevent cavitation of the walls of the well.

29.83 The existing wells with diesel pumps may not penetrate the full thickness of the aquifers. Lengthening of the intake pipe may be helpful in some cases.

Chemioal Analyses

29.84 The salinities of the karez waters and well waters should be studied seasonally. A mobile chemical laboratory, whioh would fit into the body of a Jeep Station Wagon, would be useful.

Workshop

29.85 A mechanical workshop will be necessary to service the well machinery. 


\section{PART VII}

\section{CHAPTER 30 - BCONOMIC GEOLOGY}

30.1 The final chapter is conoerned with the few minerals which have been observed during the work of the Speoial Fund, and with a short discussion on the hydrocarbon potentialities.

30.2 In the area which was examined unfortunately no minerals have yet been found which are likely to increase the economic prospects of the region, but it must be stressed that no systematio surveys were carried out.

30.3 It was hoped to find Bauxite in consequence of the knowledge that the Cretaceous limestones had been exposed above sea level at the end of the Cretaceous period. Evidently, however, the earth movements resulted in acute folding, immediately followed by active erosion, so that no time elapsed for the quiescent development of Bauxite under plateau conditions.

30.4 The following minerals will be discussed:-

Wollastonite

Haematite

Suspected Kaolin

Limestones

Rock Salt and Gypsum

Rock Salt

Hydrocarbons
Contact-metamorphic mineral in Flysch.

Late magmatic hydro-thermal veins in pillow basalt.

Metasomatised aoid sills intmuded within the Farah Volcanic Series, but not found to be of interest. A chemical analysis of one sample of Cretaceous limestone is given. Evaporites in inferred Lower Cretaceous Saline Series. Evaporites in Namakzur Lake. A brief discussion is given on the possibility of locating hydrocarbons in southern Afghanistan.

\section{Wollastonite $\left(\mathrm{CaSiO}_{3}\right)$}

30.5 Amongst a group of hills located about $6 \mathrm{Km}$. south-west of Dehzak village, there is a remarkable exposure of Wollastonite on hill 902 at geographical coordinates $32^{\circ} 34$ !: 620 $29^{\prime}$, which rises about 100 metres from the Dehzak plain. The south western part of the hill consists of granodiorite with some greenstone bodies. On the eastern quadrant are alternations of marble and calo-silicate bands which dip $15-20$ towards the northwest, except where contorted at the ieneous contact. The summit has rhyolite and metamorphosed Flysch sandetone.

30.6 The Wollastonite occurs in continuous bands, and discontinuous lenses, within marble and calc-silicate rock. The bands are up to $10 \mathrm{~cm}$. in thickness and individual crystals of Wollastonite are as much as $2 \mathrm{~cm}$. in length. The whole assemblage is a contact-metamorphic facies of the Flysch, and demonstrates that the parent rock, before metamorphism, must have consisted of alternations of purer limestone beds with beds of sandy limestone or calcareous sandstone. Some of these bands must have had a mineral composition of about $62.5 \%$ calcium carbonate and $37.5 \%$ quartz in order that pure Wollastonite could be produced. 
30.7 Wollastonite has a commercial use in the mamufacture of refractories. In the case of the Dehzak oocurrence there is certainly a considerable amount of the mineral present on the east side and north-east side of the hill. With the new highway between Herat and Kandahar under construction, oommunioations will be greatly improved, but it is unlikely that the Wollastonite will have any commeroial use in the near future on acoount of the lack of indigenous industries. At present the material is only of theoretical interest.

\section{Haematite}

30.8 Numerous veins of micaceous heematite were found in the pillow basalt at the Asarisum dam site, Hari Rud $\left(34^{\circ} 28^{\prime}, 64^{\circ} 59^{\prime}\right)$. These veins are lentioular, expanding in places to a few centimetres, and dying out laterally along the shear zone. The veins are of late magmatic origin. For haematite to be present in commeroially exploitable quantities, several million tons are required. The veins at Asarisum are only of academic interest.

30.9 A somewhat similar material was found in November 1960 as pebbles in the Malman Rud gravels. The pebbles are olearly derived from higher up the catohment, and may have come from the layered basic rocks which are seen from the air on the Ariana route between Kandahar and Herat. Hills $1909 \mathrm{~m}$. (32 $\left.42^{\prime}: 63^{\circ} 16^{\prime}\right)$ and $1730 \mathrm{~m}$. $\left(32^{\circ} 43^{\prime}: 63^{\circ} 19^{\prime}\right)$ consist of dark basic or ultrabasio rocks whioh may be basalts or layered gabbros, and rest upon the acid granites or granophyres of the conspicuous oval depressed outcrop $57 \mathrm{Km}$ in area which is mentioned in Chapter 4 para. 5. The relative abundance of the pebbles in the Malman gravels near the Farah Rud confluence sugests a near source, and further prospecting would be justified. The material of the pebbles was never positively identified, since samples which were taken to Kabul were mislaid.

\section{Suspected Kaolin}

30.10 The grey and white-weathering aoid sills which are so prevalent as intrusions within the more basio Farah Volcanio series have the external appearance of showing some degree of kaolinisation. The material is so altered by metasomatism that no satisfactory thin section for examination under a polarising mioroscope could be made. A sample of white acid sill from Robai Turkan ( $32^{\circ} 43^{\prime}$ : $62^{\circ} 56^{\prime}$ ) was analysed, with disappointing results.

\section{Normative Constituents}

$\begin{array}{lc}\mathrm{SiO}_{2} & 74.26 \% \\ \mathrm{Al}_{2} \mathrm{O}_{3} & 10.40 \\ \mathrm{Fe}_{2} \mathrm{O}_{3} & 0.98 \\ \mathrm{TiO}_{2} & 0.22 \\ \mathrm{CaO} & 2.42 \\ \mathrm{MgO} & 0.51 \\ \mathrm{~K} 2 \mathrm{O} & 2.24 \\ \mathrm{Na}_{20} & 2.35 \\ \mathrm{H}_{2} \mathrm{O}+105^{\circ} \mathrm{C} & 4.12 \\ & \\ & 97.50\end{array}$

Analyst W.H. Herdsman

$\begin{array}{llr}\text { Free quartz } & 47.2 \% & \\ \text { Orthoclase } & 13.3 & \\ \text { Albite } & 19.8 & \\ \text { Anorthite } & 11.2 & \text { or Kaolin } \\ & & 10.3 \\ \text { Ilmenite } & 0.4 & \end{array}$

There is excess combined water even if Kaolin is assumed to be present. If Kaolin is present, there is uncombined lime. If Anorthite is present, there is muoh water not capable of being combined with alumina as Kaolin. 
30.11 The analysis is somewhat suspeot, but it may be accepted that alumina is present in small quantity. Indeed, the alumina in a normal granite averages $13.1 \%$ and in an alkali granite 12.5\%. In spite of appearances, therefore, these metasomatised granophyrio rocks have no excess alumina, and such Kaolin as may be present is not of any economic interest.

\section{Limestones}

30.12 The Farah region abound in outcrops of limestone of potential value for the manufacture of cement. Due to the lack of suitable fuel it does not appear as if any cement faotory is likely to be established in the near future. One sample of limestone was, however, collected for chemical analysis. This sample oonsisted of a series of small ohips of Cretaceous limestone collected from the Adraskand tangi, $32 \mathrm{Km}$. south of Shindand, near coordinates 33001' : 62009'.

$\begin{array}{lrlr}\mathrm{SiO}_{2} & 2.06 \% & \text { Calcite } & 86.6 \\ \mathrm{Al}_{2} \mathrm{O}_{3} & 0.95 & \text { Magnesite } & 8.8 \\ \mathrm{Fe}_{2} \mathrm{O}_{3} & 0.41 & \text { Iron Oxides } & 0.41 \\ \mathrm{CaO} & 48.51 & \text { normative albite } & 3.0 \\ \mathrm{MgO} & 4.21 & & 98.81 \\ \mathrm{~K} 2 \mathrm{O} & 0.09 & & \\ \mathrm{Na}_{2} \mathrm{O} & 0.82 & & \\ \mathrm{CO}_{2} & 42.66 & & \\ & \overline{99.71} & & \end{array}$

Analyst W.H. Herdsman

30.13 A magnesia content of $4.21 \%$ is somewhat high, being above the $2.6 \%$ which is normally regarded as the upper limit for the mamufacture of Portland Cement. Alkalis are slightly above what is regarded in the United States as acceptable in the case of Portland Cement being used with aggregates from voloanic rooks which contain opaline silica. While many of the sources of aggregate along the Farah Rud and Hari Rud contain volcanio cobbles and pebbles, it is not as yet known to what extent these might be reactive, and might induce an alkali reaction with highalkali cement.

\section{Rook Salt and Gypoum}

30.14 Rook salt and gypoum are found associated with a sedimentary Saline Series of probable Cretaceous age on the north side of the range between Shaharak and Khaminj in western Hazarajat. The Saline Series orops out in the core of a dome, surrounded by inferred Cretaceous limestones. The oore is orientated almost north-south and is $8 \mathrm{Km}$. long and $2-4 \mathrm{Km}$. wide. About $2 \mathrm{Km}$. NNW of Zer-i-Kotal village (34015', $64^{\circ} 23^{\prime}$ approx.) at an altitude of approximately $2500 \mathrm{~m}$., there is an adit leading to underground salt excavations. The Saline Series is provisionally regarded as Lower Cretaceous in age, but no fossil evidence was obtained from the overlying Ilmestones which could substantiate this supposition.

30.15 The greater part of the Saline Series consists of pale chocolate-coloured marls. Interbedded with the marls are beds of dolomite, gypsum and marl-breocia. The dolomite and gypsum are well exposed on cliffs overlooking the route one kilometre north-west of Zer-i-Kotal. The massive rock salt is only found in the mine whioh could not be visited due to lack of time. The salt was stook-piled along the route, and is evidently taken over the $2900 \mathrm{~m}$. Kotal for sale in Shaharak baza ar The area is probably snow-bound for 4-5 months in the year. 
Recent Salt

30.16 The lake of Namakzar $\left(34^{\circ} 00^{\prime}, 60^{\circ} 30^{\prime}\right)$ on the frontier between Afghantstan and Iran, has for long been the source of salt sold in the bazars of the lower Har1 Pud Valley. In the Ghurian bazar $\left(34^{\circ} 20^{\prime}, 61^{\circ} 28^{\prime}\right.$ ) some samples of the lake salts were obtained, and were analysed by Dr. Menon of the U.N. Special Fund team.

30.17 The analyses of three separate layers within one blook of lake salt indicated a sodium ohloride content varying from 79.5 to 83.3 percent with small amounts of sodium and potassium bicarbonate and up to 5 percent of magnesium and caloium chloride. The sulphate ion is absent from one of the layers and was only 0.016 and 0.018 percent in the other two layers, indicating that gypsum is virtually absent. This lack of cypoum is a characteristic of evaporites derived from inland lake waters as distinct from sea water.

\section{Hydrocarbons}

$30.18 \mathrm{~A}$ long discussion of the oil potentialities of southern Afghanistan would be out of place in the context of engineexing geology, and only a few aspects of the problem will be discussed in this report. Oil and natural gas have been located in some quantity in northern Afghanistan around Sar-i-Pul, but it has not been poseible to obtain any details from official sources. It is understood that produotion will be derived from several thin Cretaceous sands at relatively shallow depths down to 2,000 m., located in moderately open anticlines. These occurrences belong to the Amu Darya oil belt, other fields being located north of the river in south-central Soviet Asia.

30.19 In Pakistan oil and natural gas produotion is mainly from Eocene limestones in moderately folded structures which lie adjacent to the Basement Complex of peninsular Indo-Pakistan, and on the peninsular side of the highly folded and overthrust Kala Chitta (Margala) zone. The natural gas accumulation of the four main structures located in the Khairpur-Jacobabad re-entrant was estimated by Tainsh, Stringer and Azad up to 1959 to be $280,000,000,000 \mathrm{~m}^{3}$, of whioh $200,000,000,000 \mathrm{~m}^{3}$ is methane. (Bull. Ass. Am. Petr. Geol. 43, p.2694, 1959).

30.20 In the Cambay region of Gujarat, India, production is from Eocene-Oligocene sands located in gentlo antiolines close to the peninsular Basement.

30.21 Several unsuccessful exploratory holes, between 3,000 and 4,000 metres in depth, have been drilled from the Makran coast, past Karachi, and along the flanks of the Kirthar and sulaiman ranges. These met great thicknesses of Flysoh-like sediments. It is understood that the Eooene Flysch of Paktia Provinoe, between Urgun and Gardez, which consists of shales with an inoreasing proportion of sandstone towards the top of the succession, reaches a thickness of 9500 metres. By contrast, the mainly calcareous Eooene of the Sui natural gas field in Pakistan $\left(28^{\circ} 38^{\prime}: 69^{\circ} 13^{\prime}\right)$ has a thiokness of 1640 metres.

30.22 Attempts to obtain production from the highly folded and overthrust zone of Mesozoic and Paleogene rocks in the Kala Chitta (Margala) north of the Potwar plateau have failed, and it is improbable that the Mor and Pab ranges north of Karaohi would have retained former oil accumulation. 
30.23 In south-west Iran the oil occurs in the Oligocene-Miocene Asmari limestone, in antiolines which are moderately squeezed. The oil belt lies south-west of the much more highly disturbed zone of the Zagros mountains. East of longitude $57^{\circ} \mathrm{E}$ the oil belt dies out and is replaced by the Makran zone of coloured Mélange and Flysch with exotic blocks. The Jurassic-Cretaceous Coloured Mélange consists of a mixture of shales, marls, limestones and cherts, which are associated with a volcanic group of basalts, pillow lavas, serpentines and agglomerates. Southwards, towards the Makran coast, there is a zone of exotic blocks resting on Flysch-type grey shales, somewhat analogous to the great saucers of sandstones in Ramree and Cheduba islands, off the Arakan coast of Burma, which rest on highly disturbed shales. Indications of hydrocarbons are very rare in this region, and deep tests on the Makran coast near Karachi were failures.

30.24 Southern Afghanistan lies in a triangular region that is wedged between the productive zones of Iran, Indo-Pakistan and the Amu Darya. The relations with the Amu Derya zone on the north side are not known. Between southern Afghanistan and the hydrocarbon zones of Iran and Indo-Pakistan it may be noted that there intervene zones of highly complex folds that have hitherto proved to be unproductive. As discussed in Chapter 4 para.18 and Chapter 5 para.11, the area has a different stratigraphical and tectonic character from Indo-Pakistan, and from the Persian gulf.

30.25 Vredenburg showed as early as 1901 that the Eocene shales of western Baluchistan possess both regional and contact metamorphism. The regional metamorphism is of epi-grade type, with production of sheeny micaceous phyllites. This condition has been confirmed by more recent work by the writer in West Pakistan and Afghanistan (Chapter 3, paragraphs 14-18), and it must be accepted that over wide areas the Flysch, ranging in age probably from Cretaceous to Miocene, is in no condition to contain oil. It is possible that the Flysch may originally have been the source rock for hydrocarbon generation, but the hydrocarbons would have been driven out by tectonic stress and low-grade metamorphism, and the question is whether or not they could have migrated and remained trapped in some of the sandstone members of the Flysch, and in adjacent bodies of Cretaceous and Tertiary limestones. In general the Flysch sandstones tend to have a calcareous cement and to lack matrix porosity, although hydrocarbons could accumulate along the joint and bedding planes.

30.26 There is much evidence for the folding and active erosion of the Cretaceous limestone before eruption of the Farah Voloanios and associated Flysch. Indeed, cobbles of fossiliferous Cretaceous limestone are found in Flysoh conglomerates that underlie the Farah Volcanics between Robai Turkan and Aliki Nai (32048', 62059'). It would appear probable, therefore, that in such areas any hydrocarbons which may have migrated into the Cretaceous limestone would have been released and lost when the limestone was uplifted and eroded.

30.27 In the highlands of south-central Afghanistan the Cretaceous limestone is in many places present as outliers on high mountain masses. The limestones of Tasra Kai, Asarisum, Tangi Azao and Tangi Shah are all tilted by folding and partially eroded. At Tangi Shah the limestone only $1 \mathrm{Km}$. north of the dam site was completely eroded before deposition of the Neogene, which rests directly on the same slates that in the gorge itself underlie the limestone. Such oonditions are not favourable for retention of hydrocarbons. 
30.28 It does not necessarily follow that uplift and erosion was ubiquitous. Hydrooarbons may esoape along actively rising and eroding antiolines but may yet be retained in intervening areas where folding was less intense, and erosion did not reach the partioular stratum in which hydrocarbons had accumilated. It may be considered, therefore, if hydrooarbons are likely to have been preserved in Cretaoeous limestones that may lie at depth below the Registan, under a oover of PlioPleistocene conglomerates. Dr. Tokarski, reoently U.N.T.A.B. Geological Adviser to the Government of Afghanistan, oonsidered that the Kandahar Cretaceous is overlain by $400 \mathrm{~m}$. of Flysch and that there are prospects of disoovering oil in submerged structures below the Registan.

30.29 The geological environment would not appear to be propitious, partly by analogy because of the failure of so many deep holes in the Flysch zone of Pakistan, and partly on account of the earth movements whioh up-ended the Cretaceous before any of the folds plunged down into the Registan. Theoretical oonsiderations have, however, so often proved to be wrong regarding oil distribution, that geophysical work and exploratory drilling may be advisable in the Registan, even though small hopes can be entertained for preservation of oil in the exposed mountain $z$ one. 


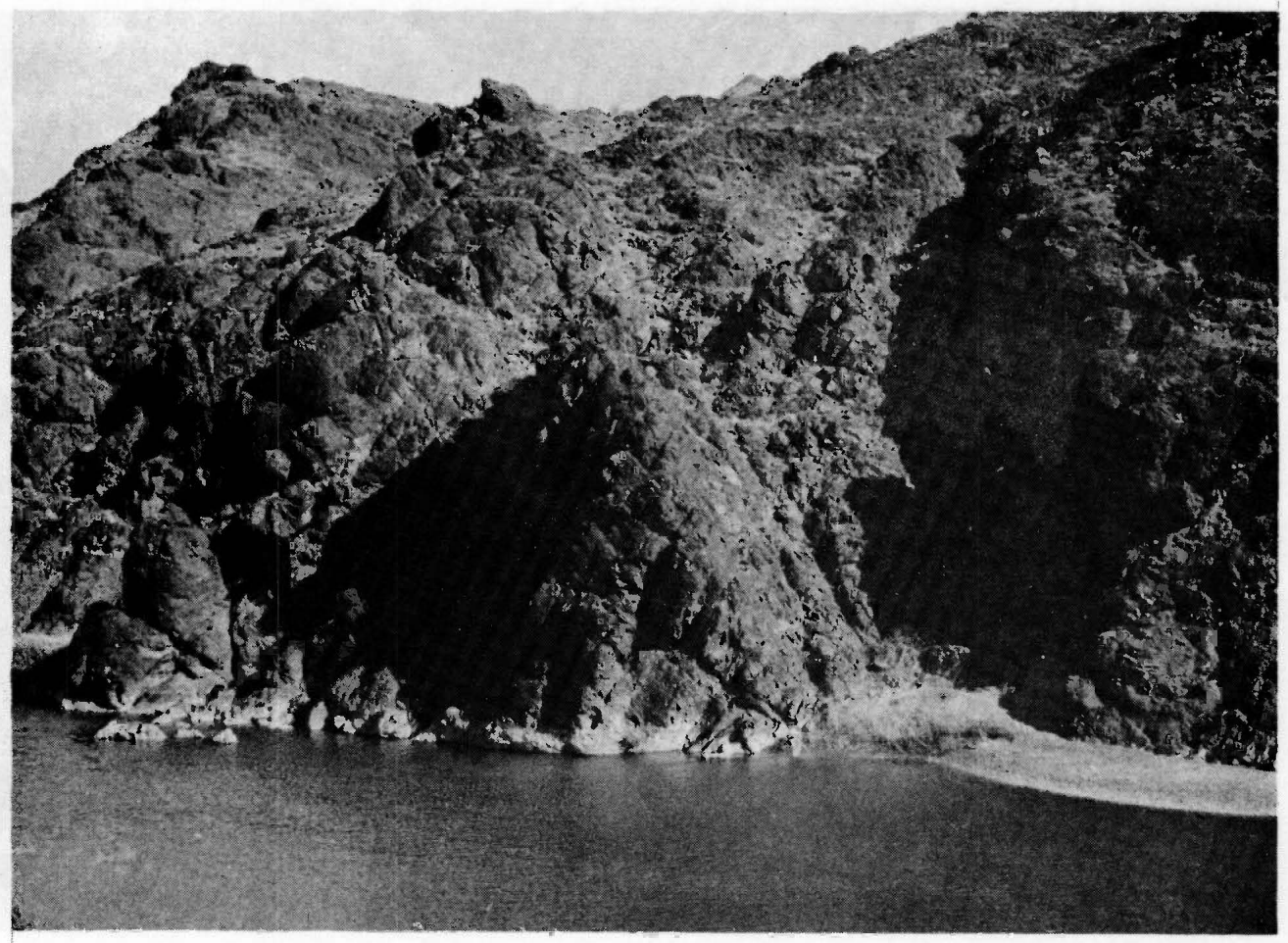

Photo 1. Gully formed along shatter zone: left bank: Farah Rud: Bakhshabad Dam Site. February 1961

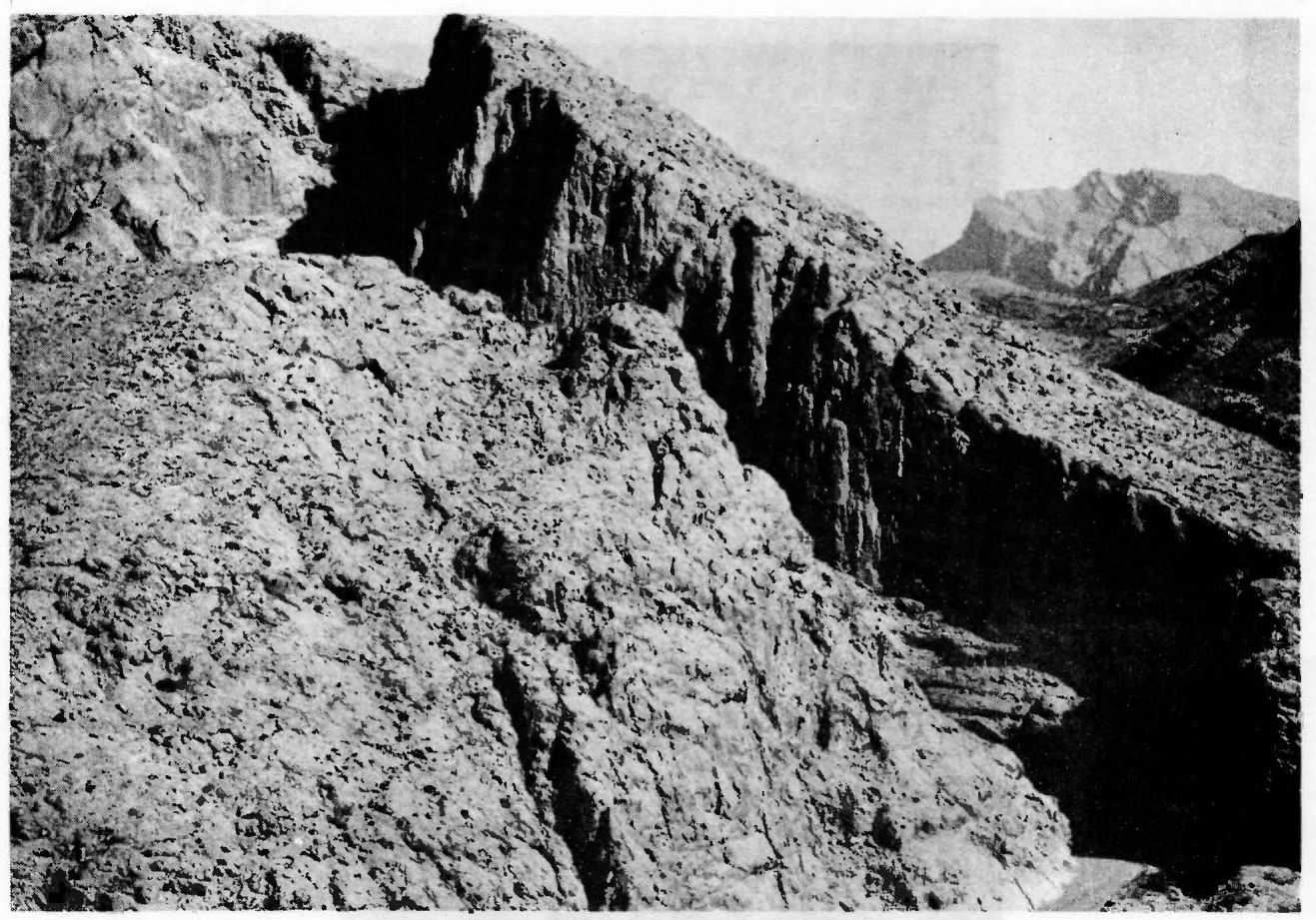

Photo 2. Exit of Lashkar Ghar Gorge: Farah Rud.

Cretaceous limestone dipping east below Farah

Volcanics: thrust fault along ravine on left

side of photograph. October 1962 


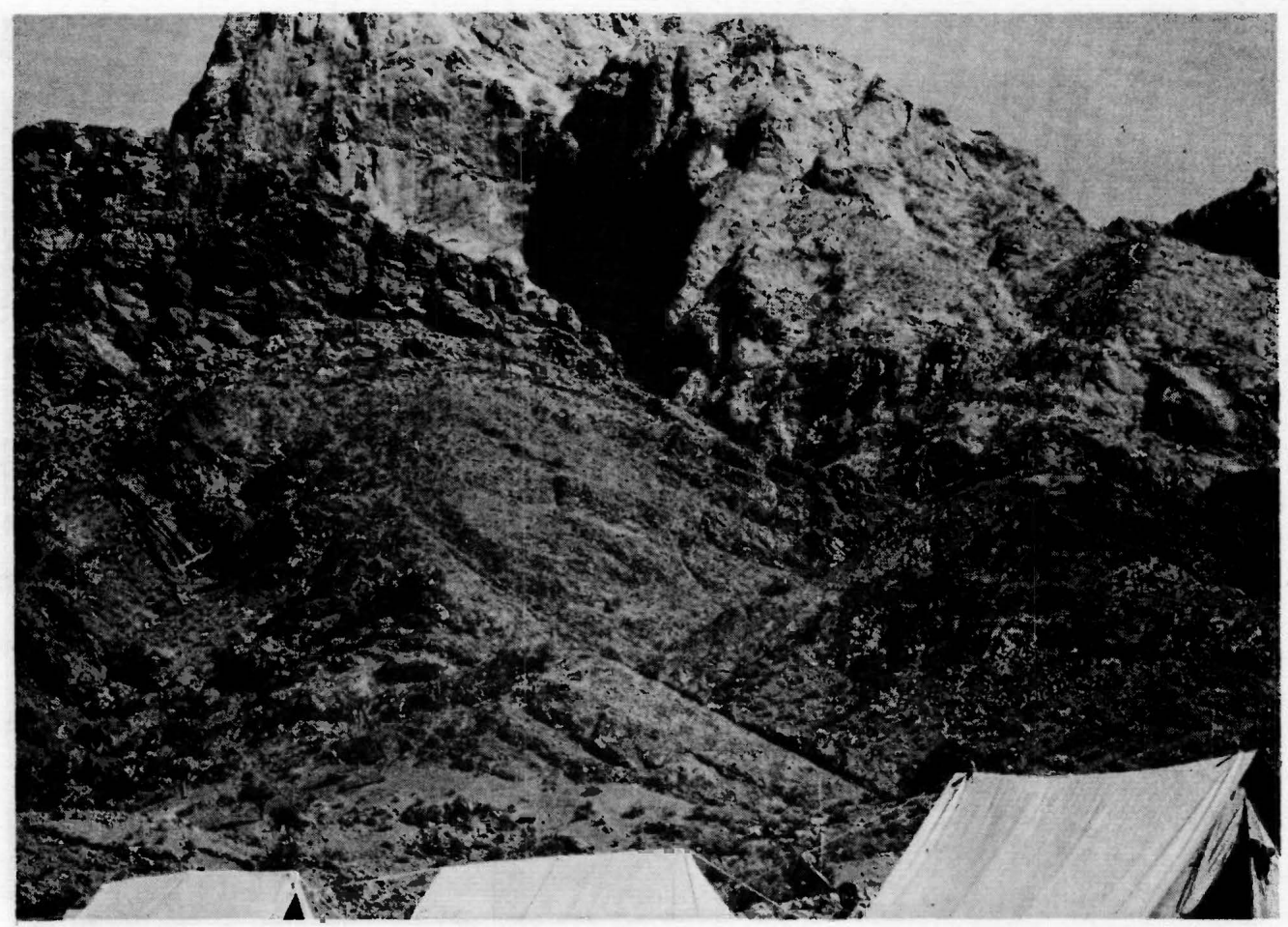

Photo 3. Overthrust of Cretaceous Limestone upon Farah Volcanics. Lashkar Ghar: Farah Rud. October 1962

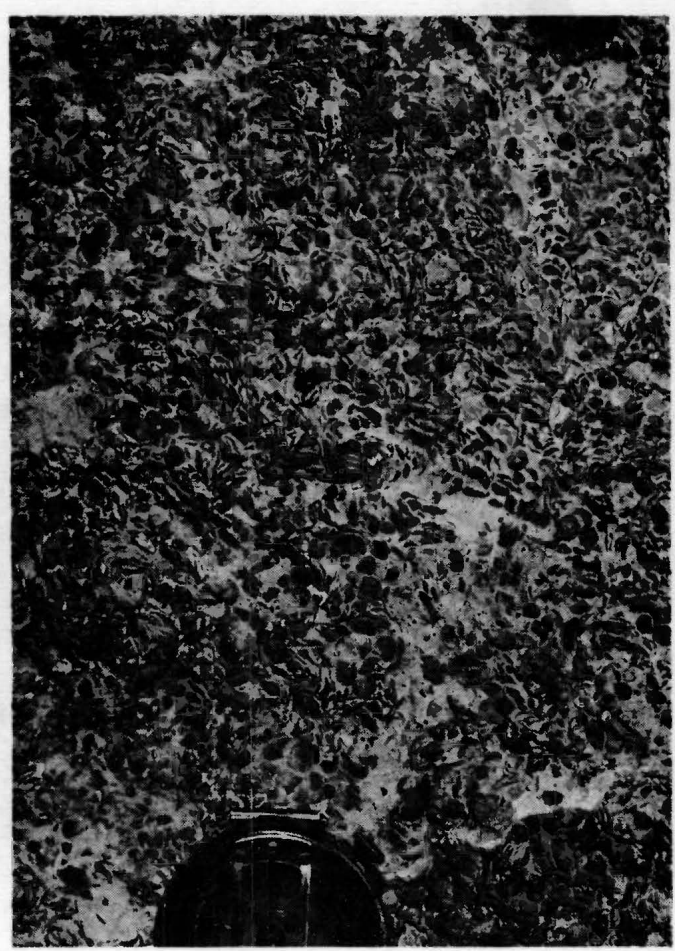

Photo 4. Orbitolina Limestone: right bank of Ghor Rud, $1 \mathrm{Km}$. upstream of confluence with Farah Rud: Lashkar Ghar. October 1962 


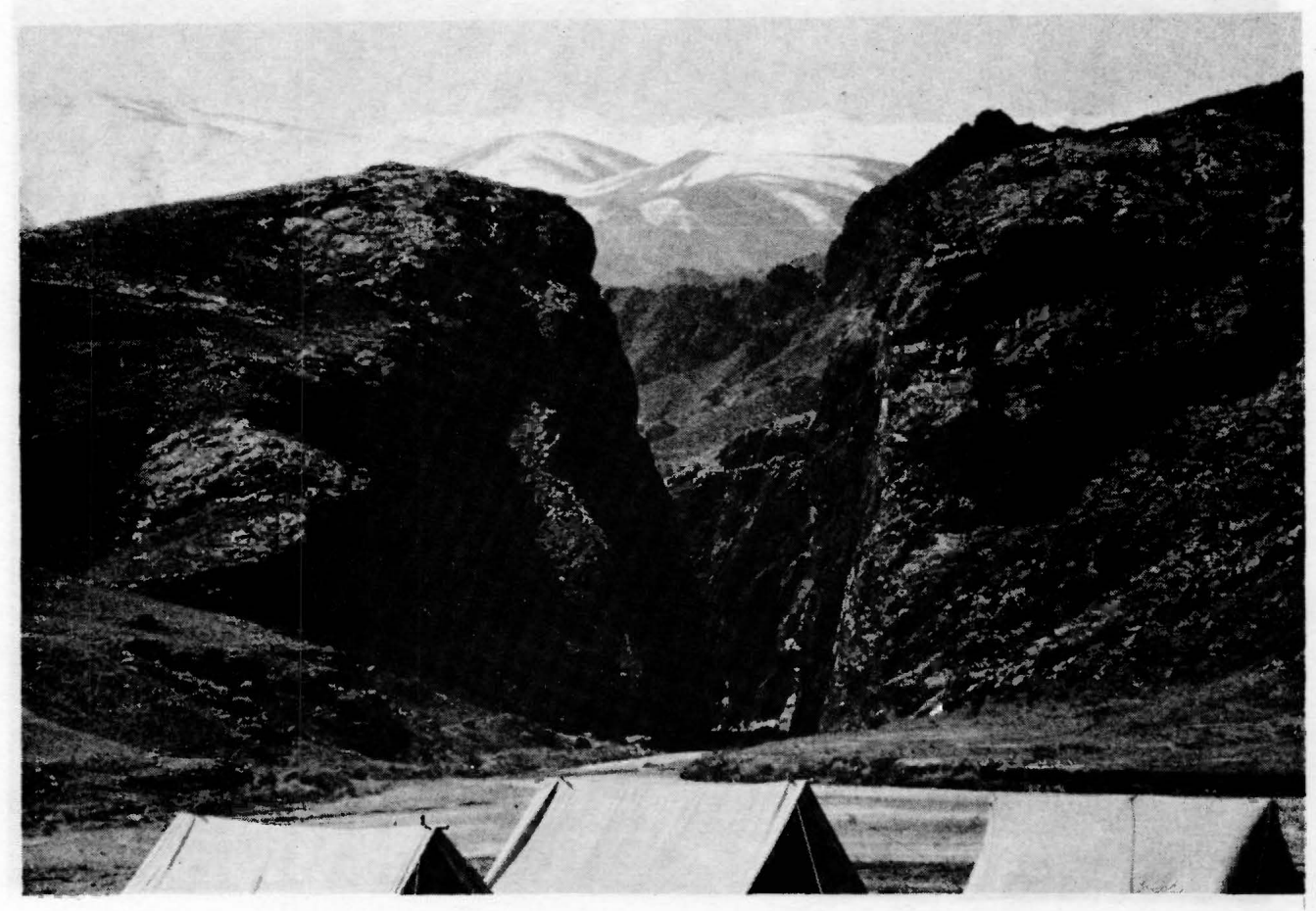

Photo 5. Tangi Shah Dam Site, Kawgan Tributary of the Hari Rud. View upstream from Safed Khara camp. March 1962

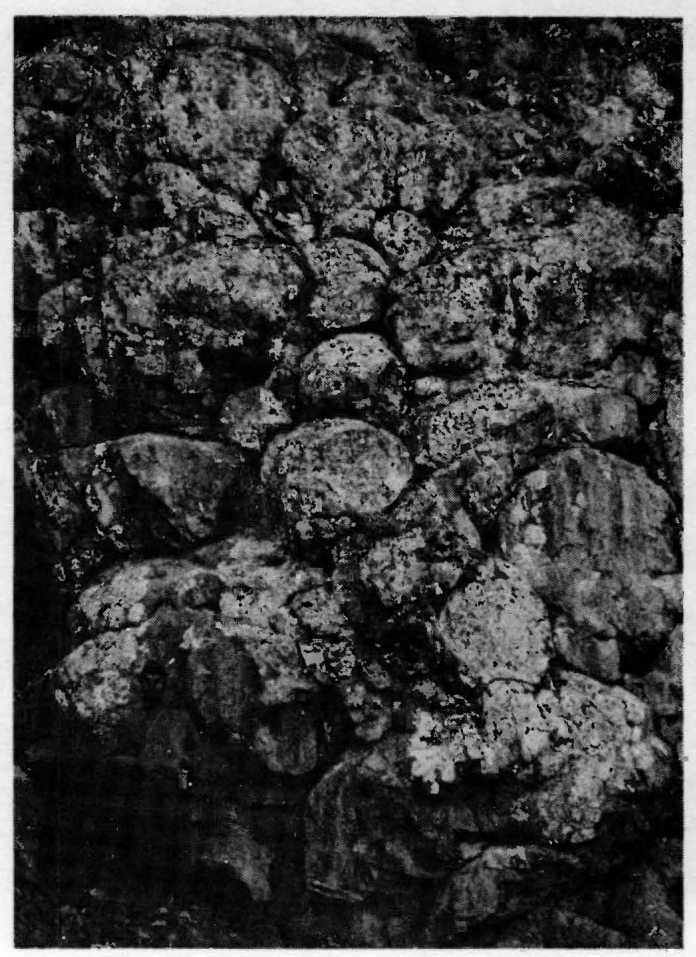

Photo 6. Pillow Lava: left bank: Hari Rud: Asarisum Dam Site. October 1961 


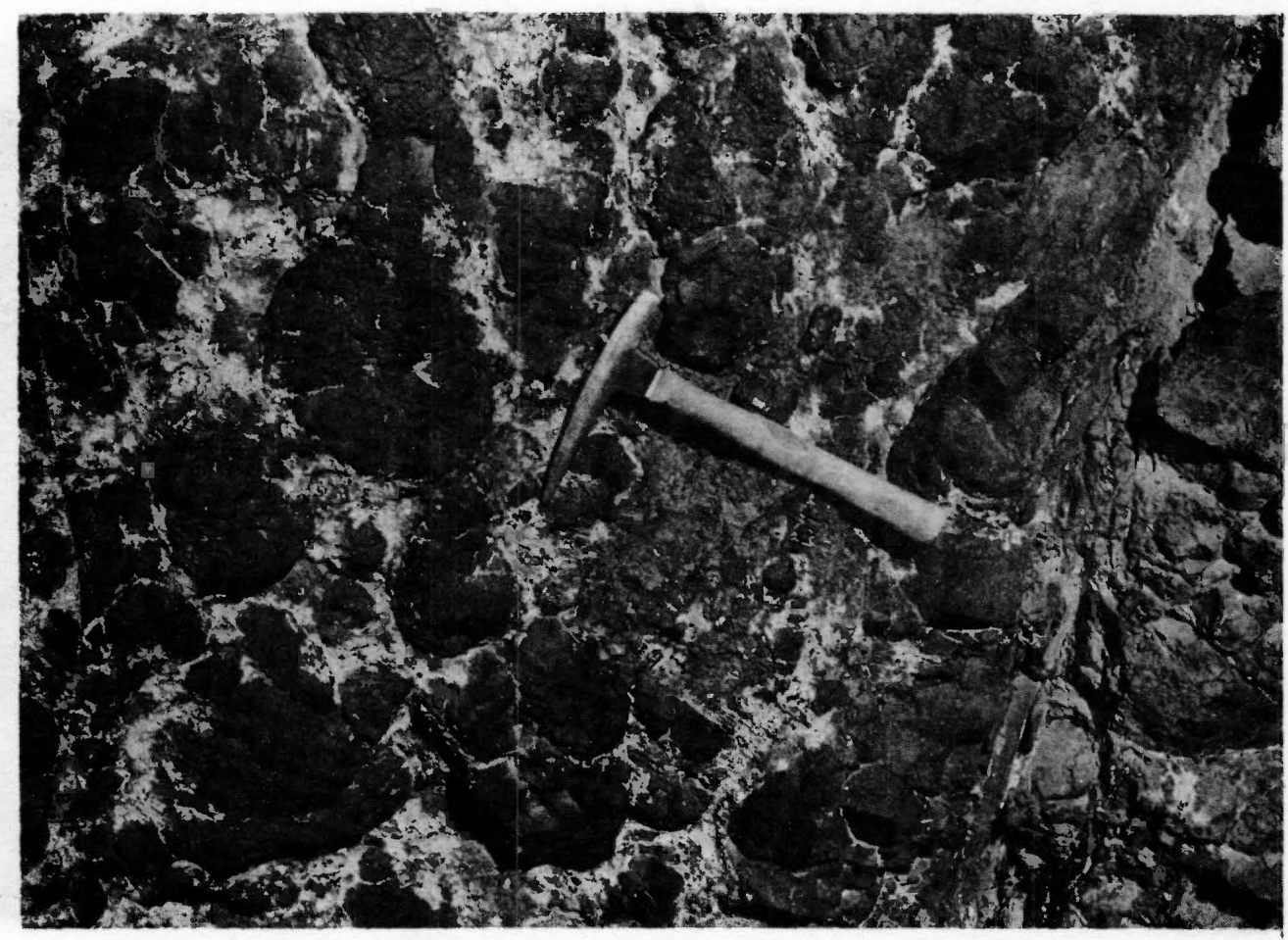

Photo 7. Pillow Lava: right bank: Hari Rud: Asarisum Dam Site. October 1961

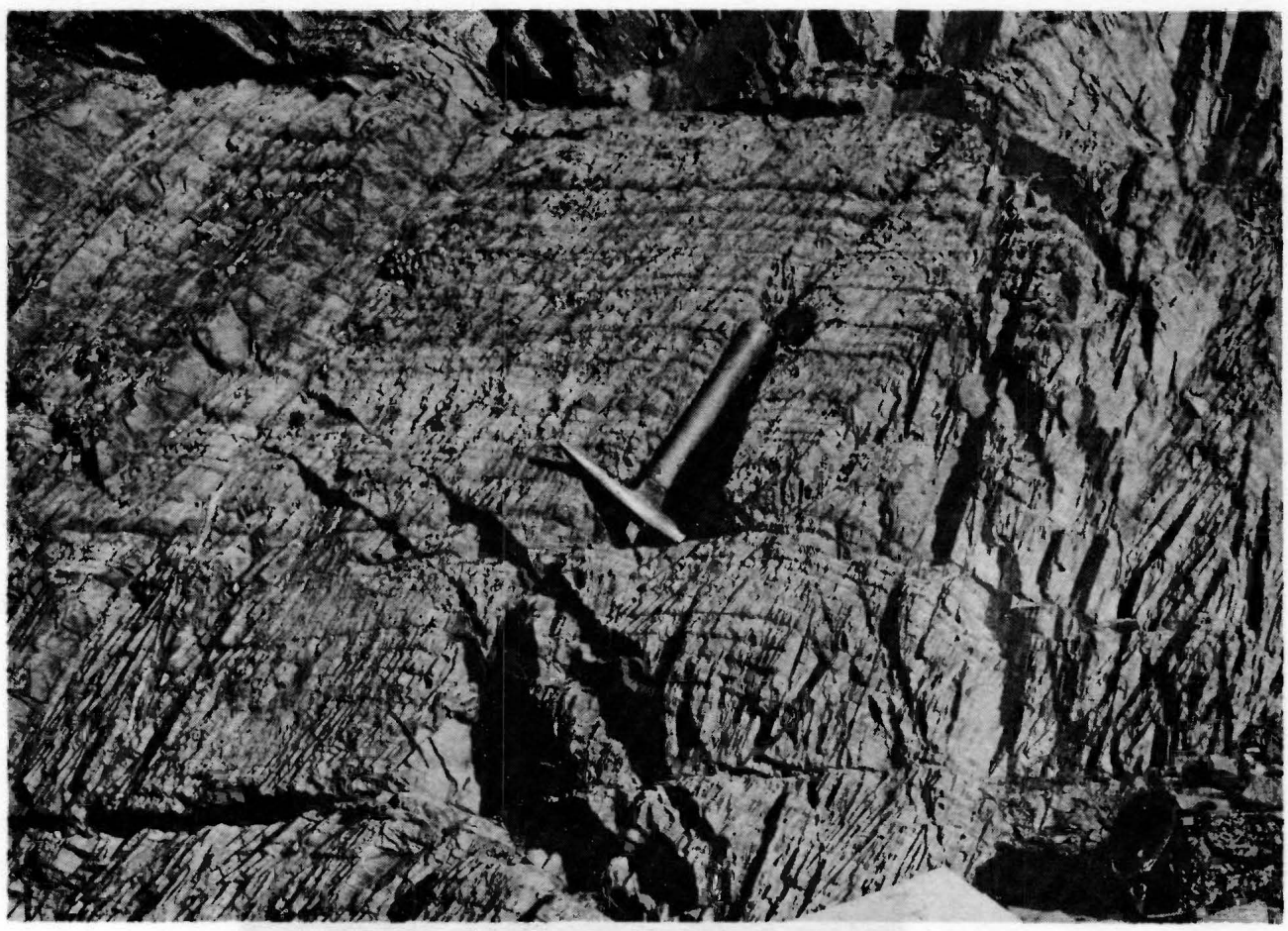

Photo 8. Slates of probable Cretaceous age, showing bedding and cleavage. Left bank: Hari Rud: Asarisum Dam Site. October 1961 


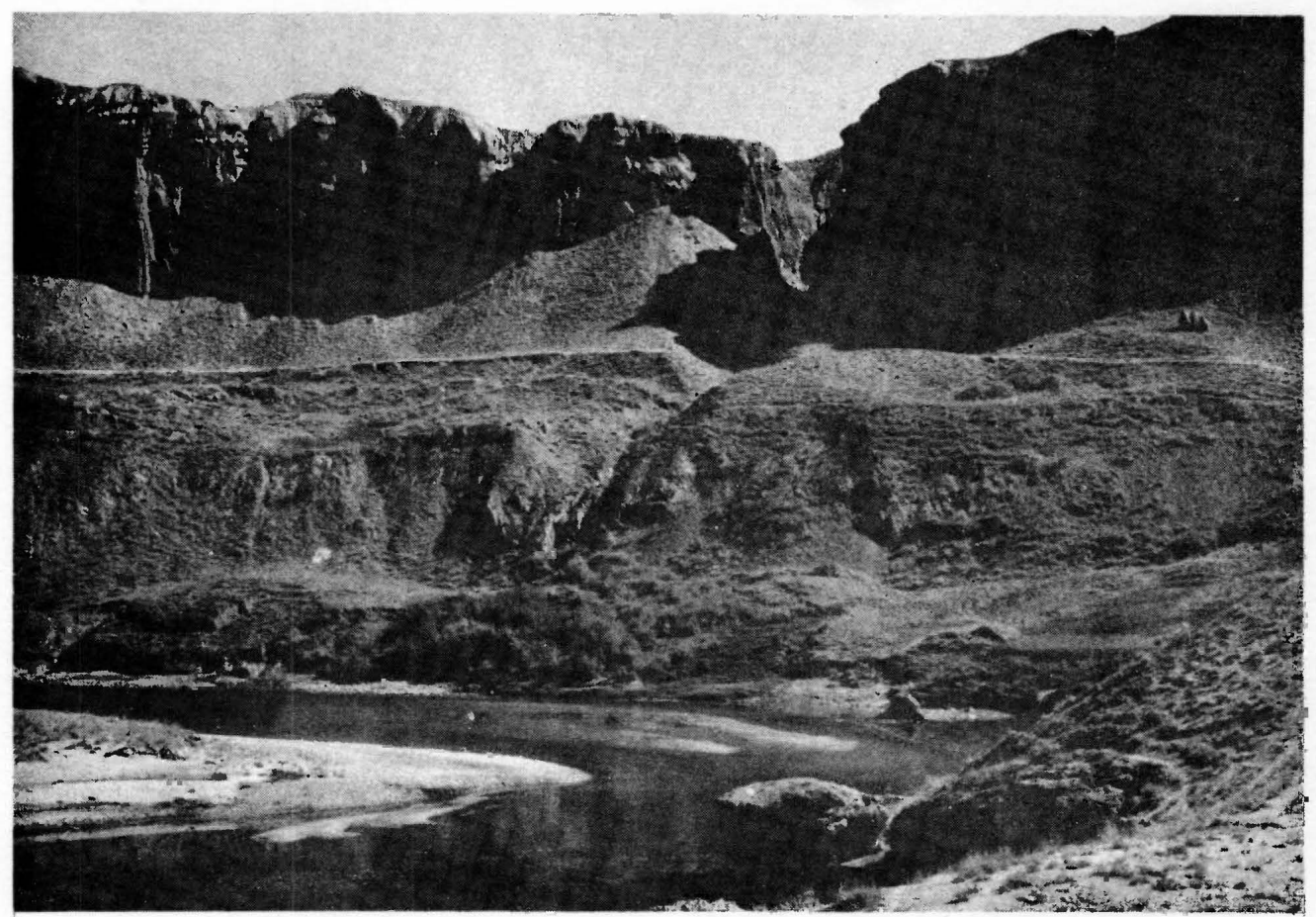

Photo 9. View eastwards of gully eroded in Neogene silts and conglomerates, $1.6 \mathrm{Km}$. south of Asarisum Dam Site, Hari Rud. The reservoir would be on the far side of the oully, which may be a limiting factor in the heigh, of the dam. November 1961

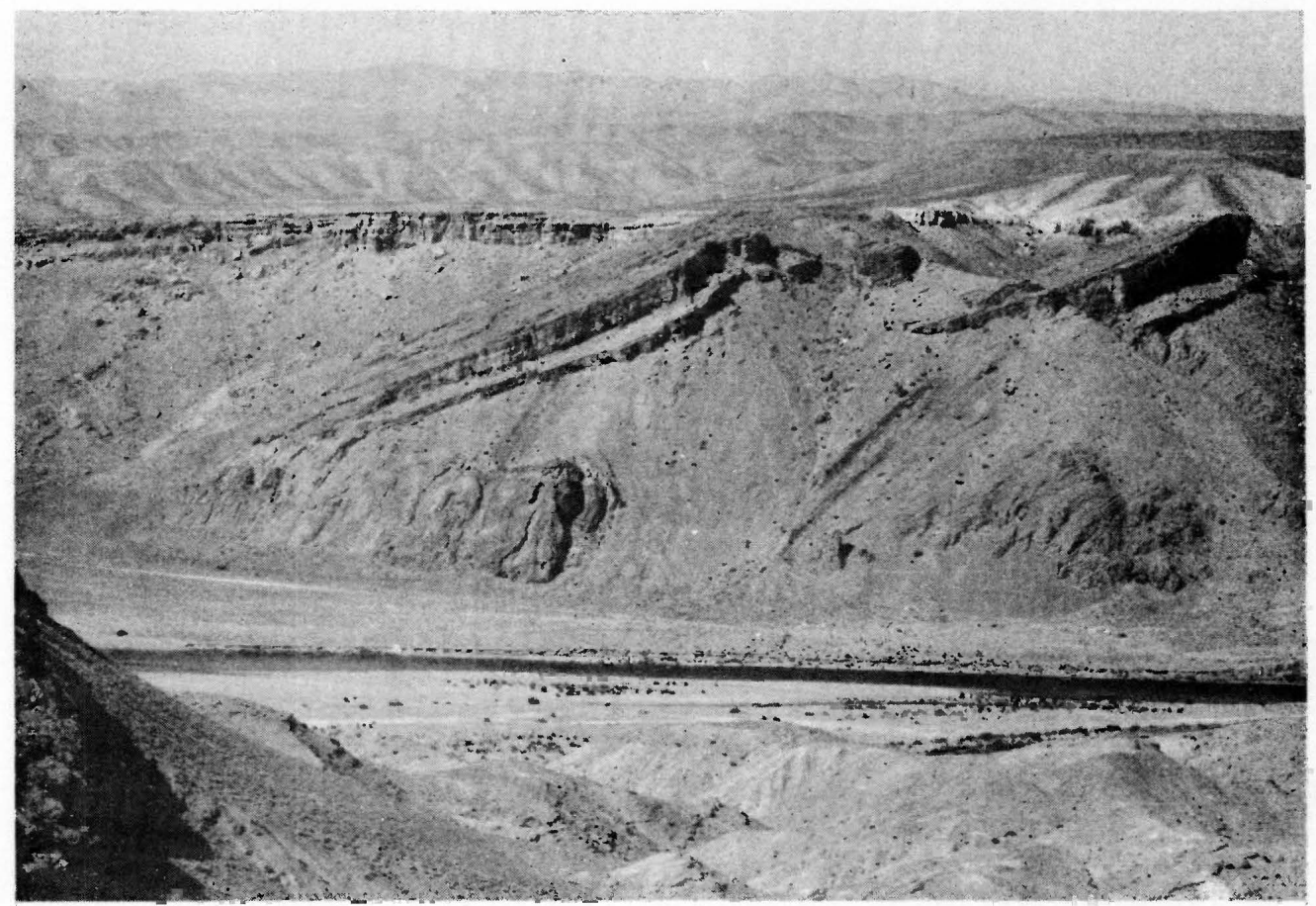

Photo 10. Unconformity of Neogene upon more steeply dipping Cretaceous limestones and shales. Right bank: Hari Rud; downstream of Tasra Kai Dam Site. October 1961 
SURVEY OF LAND AND WATER RESOURCES

\begin{tabular}{lllllllllll}
$A$ & $F$ & $G$ & $H$ & $A$ & $N$ & $I$ & $S$ & $T$ & $A$ & $N$ \\
\hline
\end{tabular}

Volume II

Section II

TOPOGRAPHIC SURVEYS

SPECIAL FUND OF THE UITTED NATTONS

FOOD AND AGRICULTURE ORGANIZATION OF THE UNITED NATIONS 
1. Introduction

2. Personrel

SCIIEDULE OF TOFOGRAPHIC SIJRVEYS

Details of Survey

1.1 Farah Plain

1.2 Bakhshahbacl Dam Site and Reservoir on the Farah Rud

1.3 Aliki Nai Ilam Site and Reservuir on the Farah Rud

1.4 Gashkber Dam Site on the Farah Rud,

1.5 Lashker Gah Dam Site and Reservoir on the Farah Rud

2. HARI RITD

2.1 Assarjsum Dam Site and Reservolr on the Hari Rud

2.2 Tasrakny Dam Site and Re:servoir on the Hari Rud

2.3 Tanci Sheh Dam site and Reservoir on the Kawgan Rud

2.4 Tagaw Kaza Dam Site aid Reservoir on the Hari Rud

2.5 Salma Dam Site and Reservoir on the Hari lud.

2.6 liarwa Weir jits on the Hari Rud

2.7 Turan Irrigation Design Plor of Represeatative Area of Herat Valley

3. KABUL

3.1 Tanci Saidam Dam Site and Reservoir on the Bala Maidan (Kabul)

13

13

3.2 Kajaw Dam Site and Reservoir on the Kajaw Rud

3.3 Gulbahar Dam Site and Reservuir on the Panjshir River

3.4 Iower Ushturshar Dam Site and Reservoir on the Ghorband

3.5 Ushturshar Dam Site and Reservoir on the Ghorbend

3.6 Jungle Chari-di-Ginorvand Dam Site and Reservoir on the Ghorband

3.7 Turknam Dam Site and Reservoir on the Tiıkman

3.8 Other Storige Possibilities investigated

CHAFTER II - NOTE ON TIE NATIOIAL MAPYING PROGRAIIE IN AFGHANISTAN!

CHAPTSR III - O'PHFR MAPS

Soil Maps

TARIES OF RESERVOIR AREAS AND CAPACITY CURVES 
No.

Title

1-19 See Section I - Geolowy

Bakhshabad and Auxiliury Reservoirs thap

Aliki Jai Reservoir lfap

Lashkorgah Reservoir Jiap

Assarasum and Tasrakay Reservir biap

Tasrakey Dam Site liap

Tangi Shah Reservoir liap

Salma Resorvoir Map

liarwa Weir Sito Map

Kajaw Reservir Mlap

Tangi Saidan Rezervoir Nap

Ghorband and Panjsilir Reservoirs lian

Bakshabad Resarvnir Area and Capacity Curves

Aliki Nai

Lashargah

Assarasum "

Tarigi Shah "

Salma "

Tangi Saidan "

Kajaw "

Tasrakay "

Tangi Azao "

Barghanah "

Khash Rud "

Gulbahar "

Lower Ushturshar

Ushturshar "

Char-di-Ghorvand.

Turkman

"

" " "

" 111111

" 1111

" " "

" 11 "

" 11 "

" 11 "

11 "

11 11

" 11

11 11

" 1111

" 11 "

" " " "

" 11 "

Air Photographic cover.

References are made in the text of Part II Vol IJ to the Drawings of Part I but refer only to the toporaphy shown thareon. 


\section{ACKNOWLEDGEMENTS}

Grateful acknowledgements of assistance given are mado to both cooperating agencies. Royal Afghan Ministry of Arriculture, Soptember 1960 - April 1963; The Water and Soil Authority of Afghanistan, April 1963 - October 1963; Office of Aerial Photography and Mappius, Ministry of Mines and Industry; for their very valuable and urfailing help in providing air photo material and maps as well as advice; the Cartographic Institute for permission to use various instruments; Govemors of Farah and Herat Provinces. 
CHAPTER I - TOPOGRAPHICAI SURVEYS

1. Introduction

Topographic surveys carried out within the United Nations Special Fund Land and Water Resources Survey, Afghanistan, were mainly concentrated on water storage sohemes al though some surveys were made to facilitate irrigation design.

All small scale mapping, at scales smaller than 1:10,000, was accomplished photogrammetrically. The average scale of the air photograph used was 1:50,000. Contouring was effected by a Zeiss Stereotope. To satisfy the engineers, 10 metre contours were attempted, but these can only be considered as good from lines. The mappine; oarried out in this manner is only of a reconnaissance standard, producing only first estimate data for engineering design.

The mapping done at soales $1: 10,000$ and larger have all been acoomplished on the ground by conventional survey methods and can be considered as being of a good engineering standard. Practically all the proposed dam sites have been mapped at scales of $1: 2,000$ or $1: 2,500$ with a 10 metre contour vertical interval. On the less precipitous sites the maps show 5 metre contours.

Dam sites were usually chosen in collaboration with the engineering geologist and maximum economic dam heights were decided upon. Consequently the reservoir contouring was usually only done up to this height.

Most of the mapping was carried out from local vertical datums. In areas where absolute datums could be tied in economically, connections were made by spirit level lines.

Except for Bakhshahbad and Tangi Saidan reservoirs where vertical photo control was aocomplished by spirit levelling, all other photo control heights were done by al timetrio levelling.

No special attempt was made to tie the mapping into the national grid. In areas where it has been done it was usually accomplished by using data from the Geological Survey advance maps. In areas where no geodetic data or advance maps existed, air photo scales were controlled by traverses or local triangulation schemes.

Nothing concrete can be said about mapping accuraoies as time has not permitted any field cheoking. However, it is obvious if development on any of the proposed projects proceeds, additional maps will be required for final design plans.

At the beginning of the survey in September 1960 and on various occasions later, the Project office borrowed air photograph check prints from the office of Aerial Photography and Mapping, Ministry of Mines and $I_{n}$ dustry.

This could only be a temporary solution and in those areas where major investigations were to take place, the air photographs were obtained. Ultimately the project had its own set of air photographs of selected areas of Afghanistan, mainly in the Farah, Herat, Katawaz, Adraskand and Kabul regions. The number of photographs were between 3,000 and 4,000 . 


\section{Personnel}

The oounterpart personnel system was in practice throughout the period of the survey. That is, one or more Afghans were attached to a U.N. officer as assistants for training in his particular field. In theory the system is sound. This section of the survey has had a total of 12 counterparts, for various lengths of time. The smallest number at any one time was five. The maximum number of U.N. technioians in the section was three. Due to the laok of continuity of service of the various counterparts, and to the lack of proper facilities for training, it is difficult to ascertain how much has been gained. If efforts could have been concentrated on those 3 or 4 counterperts who showed promise and had the background to grasp the problems, the results would have been very much better.

No attempt will be made in this report to evaluate the services of the counterpart personnel but a brief desoription is given of their partioipation in the Survey. Grateful acknowledgement is given to the counterpart personnel for their valuable assistanoe often under adverse conditions.

\section{COUNTERPART PERSONNEL}

$\underline{\text { Name }}$

Approx. Period of Service

Feb. 1961-

Aug. 1963

A. Hashimi

Nasrullah Saadyar $V$ Jan.1961-

Oct. 1963

Hamayun . Jan.1961-

Mar. 1962

A. Karim ' Jan. 1961-

Sep. 1962

Aminullah $\checkmark \quad$ Sep. 1960-

Feb. 1963

Culham Haidar

Sep. 1960-

Feb. 1963

Obidullah

M. Zahir $V$

Mohd. Yousaf

A. Hafiz $\sqrt{ }$
Apr. 1962-

Nov. 1962 .

Apr. 1962-

Nov. 1962

Dec. 1962-

Oct. 1963

Dec. 1962-

Oct. 1963
Background and Description of Participation

Graduate, University of Kabul, Civil Eng. Assisted in a number of field surveys and office computations and compilations.

Cadastral Survey School, assisted mainly in drafting and Photo Lab., spent little time on field surveys.

Afghan Institute of Technology (AIT).Assisted in field surveys, mainly levelling.

AIT. Assisted in field surveys, mainly levelling.

Cartographic Institute. Assisted in all types of field surveys.

Cartographic Institute. Assisted in all types of field surveys.

AIT. Assisted in the field for short periods only.

AIT. Assisted in the field for short periods only.

AIT. Assisted in levelling for irrigation design mainly.

AIT. Assisted in the field for short periods and drafting. 
Name

Amir Shah

a. Farouk

\section{A. F. Palliater}

P. Leggiadro

J.a. Rijadijk
Approx. Period of Service

Dec. 1962-

Oct. 1963

Deo. 1962-

Oct. 1963
Background and Description of Participation

AIT. Assisted in levelling for irrigation designs mainly.

AIT. Assisted in levelling for irrigations designs mainly.

\section{UNITED NATIONS SPECIAL FUND PERSONNEH}

Survey Engineer. September 1960October 1963. Officer in Charge of Topographic Survey Section.

Survey Engineer. March 1961-March 1963. Charged with mapping by both conventional and photogrammetric methods and photo lab. work.

Associate Expert. Survey Engineer. December 1960-June 1963. Charged with all types of mapping and office compilations. 


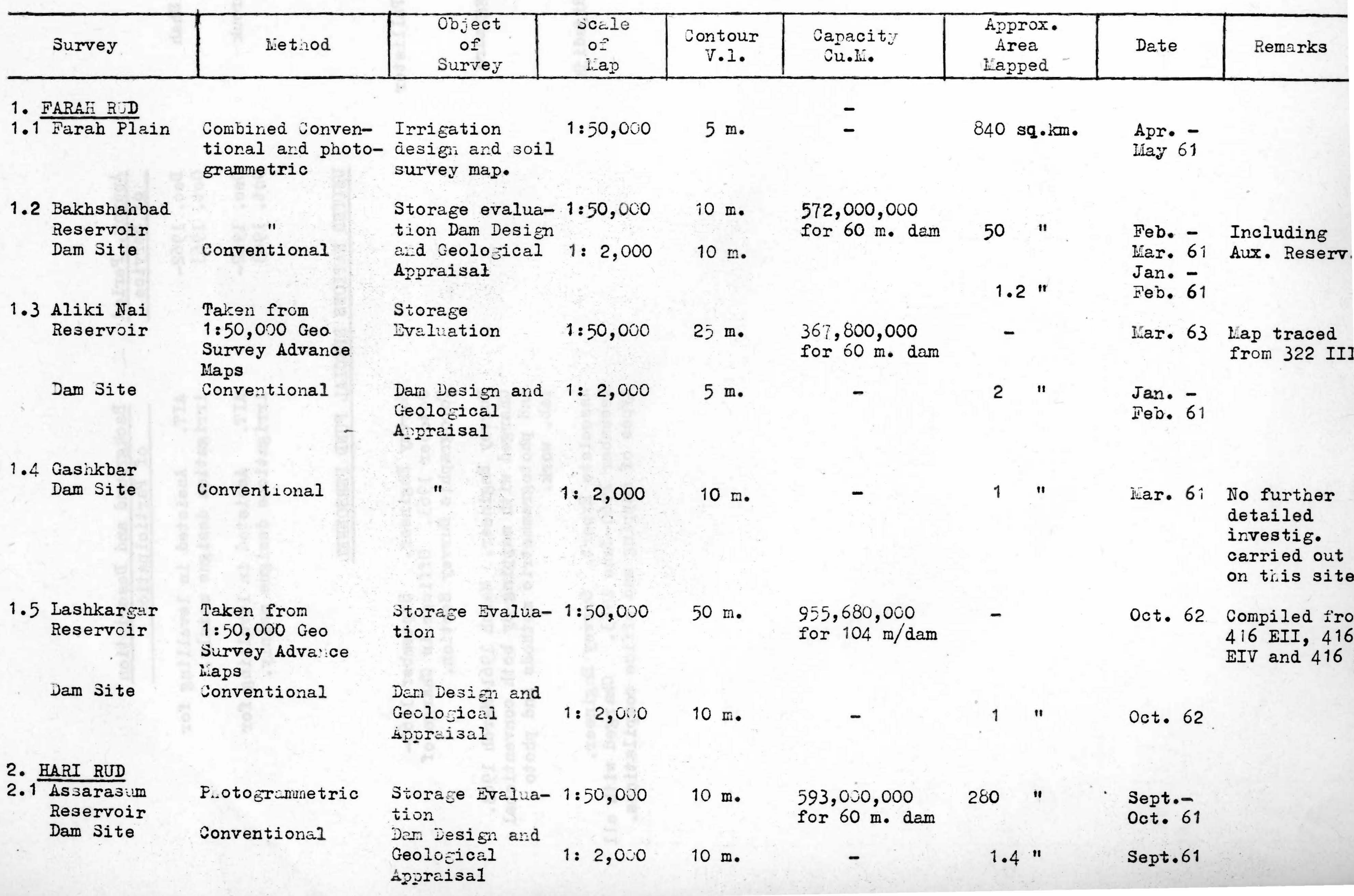




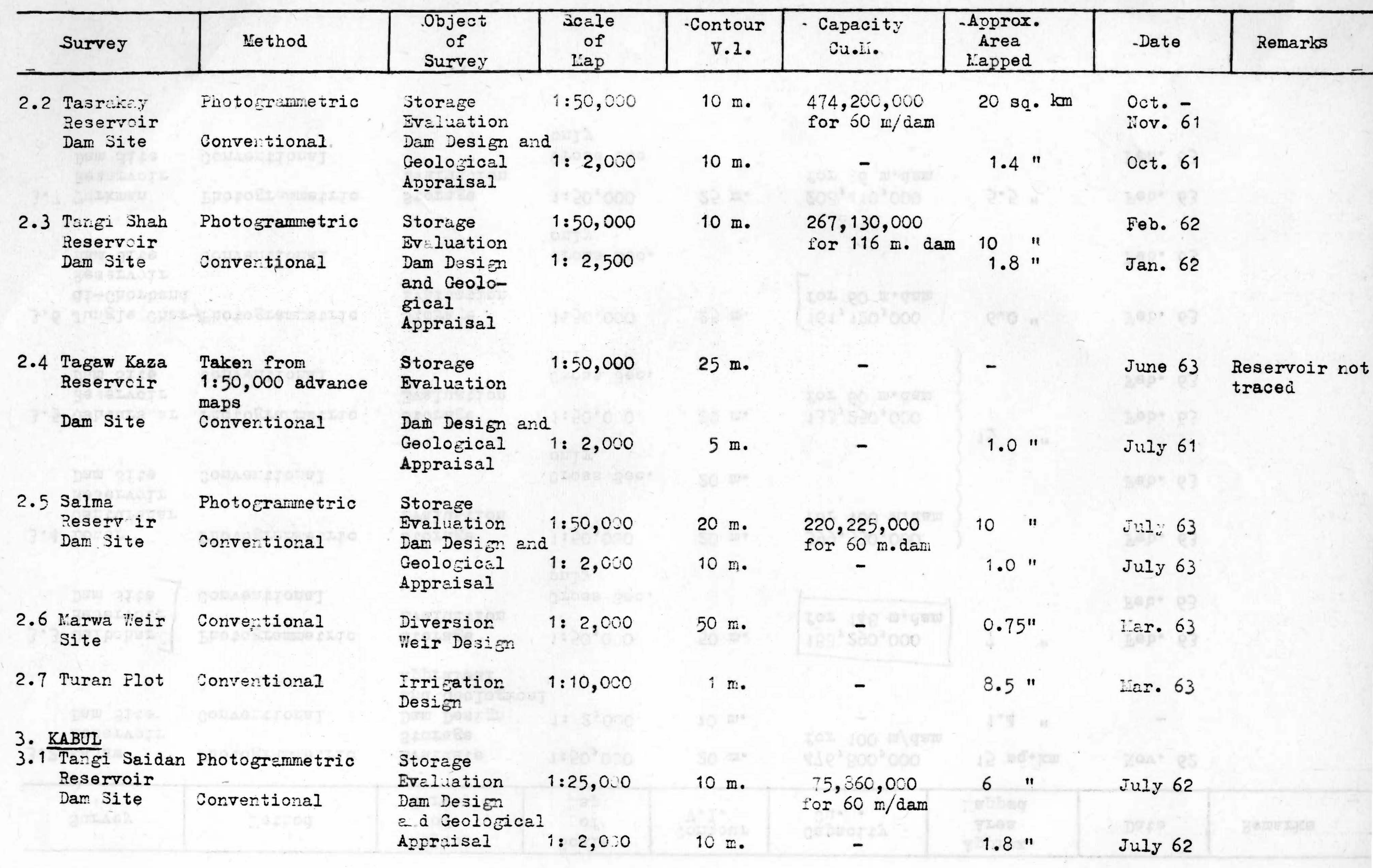




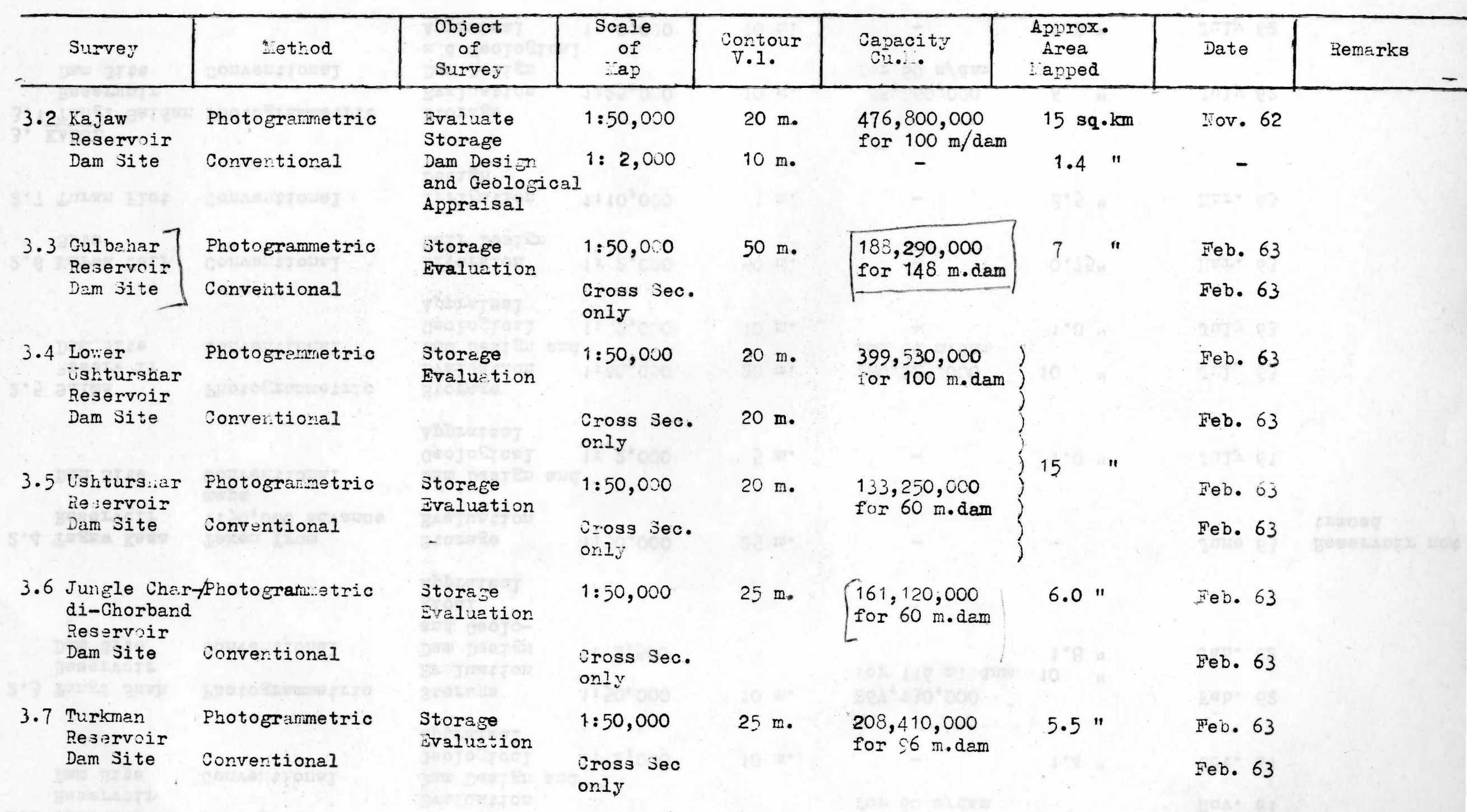




\section{$1.1 \quad$ Farah Plain}

\section{DETAIIS OF SURVEY}

Location: The area mapped is situated along the Farah Rud from Desishk village to approximately $12 \mathrm{~km}$. downstream from Farah and extends on both sides of the river to the hills.

\section{Survey: This area was mapped for two main purposes -}

(a) Base map for soil survey.

(b) Irrigation design.

To facilitate the latter, 5 metre contours were established over a portion of the total area mapped.

Air photo cover of the valley existed on a scale $1: 57,000$ approximately. Horizontal control was effected by a graphical triangulation carried out at a scale 1:20,000. This was further broken down by slotted template in scale $1: 50,000$ which was the compilation scale. Details were taken from the air photographs with Zeiss Sketchmaster. The map appears in the report on a scale $1: 100,000$ in Vol. I Drawing No. 12. The original will be in the files of Afghan Land and Water Authority.

Contours have been derived from level traverses plotted directly on the photographs in the field. All elevations and contours are referred to Afghan Geological Survey BM 7-159 (Elev. 652.757 m).

Fortytwo bench marks were established throughout the area.

\subsection{Bakhshahbad Dam Site and Reservoir on the Farah Rud}

Location: Approximate geographical coordinates are N. 32052: 7' E 62049: 7' as scaled from advance map $1: 50,000$ series.

The site is approximately 85 air kilometres N.E. of Farah. The site is in air photographs N. 7-1-14627 and 28.

Survey: At the time of the survey no reliable maps existed of the area. Ground control of air photographs was carried out in February and March 1961. This was accomplished by running levelled tacheometric traverses, both along the main river and up the large side streams to a height $+60 \mathrm{~m}$. at the dam site. The air photographs were scaled from the traverse and 10 metre contours were drawn in a Zeiss Stereotope.

In early 1962 when the 1:50,000 advance maps became available the original map was revised to scale. It was found that the original map had a progressive scale error, reaching a maximum of $5 \%$

In March 1962 additional field work was carried out to evaluate both the col into Wadi Takhtay Taymor and the storage capacity of the Wadi itself. It was thought that the Wadi might be used as an auxiliary reservoir. Both the main Bakhshahbad and the auxiliary reservoir are shown on Drawing No. Vol. II-20.

The capacity of the Bakhshahbad reservoir for a $60 \mathrm{~m}$. dam is $572,700 \mathrm{cu}$. metre (see Plan Drawing Vol. II-3I) and with a barrage in the Wadi Takhtay Taymor with its maximum level the same as the dam on the main river a further $232,810,000 \mathrm{cu}$. metres of water can be stored. A total area approximately $50 \mathrm{~km}^{2}$ was mapped at $1: 50,000$ scale. 
To fecilitate a dam desien and detailed eeological studies a large scale topographic map, 1:2,000 with 10 met,re contours was made. (See Draving lio. Vol. II-5). This survey covered about $1 \mathrm{~km}^{2}$. Both the $1: 2,000$ and $1: 50,000$ maps are referred to the same datum. BM l, situated at the upstream end of the Bakhshahbad-Gashakbar Tangi, was assumed as 300.00 metres.

\subsection{Aliki llai Dam Site and Reservoir on the Farah Pud}

Location: Approximate Geogrephical coordinates are N. 32049' E 63003' as scaled from advance maps $1: 50,000$ series.

This site is situaled approximately 100 air kilometres N.E.E. from Farah.

The site appears in air photographs N. $8^{\text {A }} 14397$ and 98.

Survey: A lerese scale topo plan was prepared for dam design and detalled geolofical mappine. Approximately $2 \mathrm{~km}^{2}$ were mapped at a scale $1: 2$,000 with a 5 metre vertical interval contour in January and February 1961. A local datum was used for the map. BM 5 was assumed as being 200 metres.

The original map was later traced with only 10 metre V.l contours and is contained in Drawine lio. Vol. II-7.

The reservoir man has been traced directly from the Afghan Geological Survey advance map 422 A III and the capacity was computed on the 25 metre contours shown thereon. (See Drawing No. Vol. II-21). The volume for a 58 metre high dam is 367,800,000 cu. metres (see Drawing lo. Vol. II-32).

By interpolation between the contours on the 1:50,000 map, bed level at the dam site arpears to be 892 m. M.S.I.

1.4 Gashlibar Dam Site on the Farah Rud

Location: The sjte is situated $2.7 \mathrm{~km}$. upstream from the Bakhshahbad site and appears in air photocraph No. 7-1-14627 and 28. Approximate geographical coordinates are $N 32052 \mathrm{I} .62051$, scale from 1:50,000 advance maps.

Survey: A Jare scale topo map, $1: 2,000$ with a 10 metre contour V.I was made in Farch 1961. The survey was based on the same vertical datum as Bakshahbad.

No further work was done on this site as it was ruled less suitable than either Aliki Nai or Bakshahbad sites.

1.5 Lashkar Gah Dam Site and Reservoir on the Farah Rud

Location: :

This site is situated $5.3 \mathrm{~km}$. downstream along the main Farah Rud from its confluence with the Ghor Rud (Nezgan) and approximately 137 air km. N.E. of Farah town.

Geographical coordinates as scaled from $1: 50,000$ advance maps are N $33^{\circ} 02^{\prime} 54^{\prime \prime}$ E 63021'44". It is shown in air photographs 9-14308 and 09.

Survey: A survey was made in order to map the dam site area in a scale $1: 2,000$ with a 10 metre contour V.I covering an area of approximately $1 \mathrm{~km}^{2}$.

A local vertical datum was used, BM 1 , as shown in Drawing No. Vol. II-9 was assumed at 74.00 metres. 
By interpolating between contours on the $1: 50,000$ advance map sheet $416 \mathrm{EIV}$, bed level at the dam site was taken to be 1,076 metres M.S.L.

No mapping was carried out to evaluate reservolr capacity. This has been measured and computed from the $1: 50,000$ advance map sheets 416 EII, 416 EIV, and 416 FII, using 50 metre contour and applying the formula $\mathrm{A} K \mathrm{~d}^{\mathrm{n}}$.

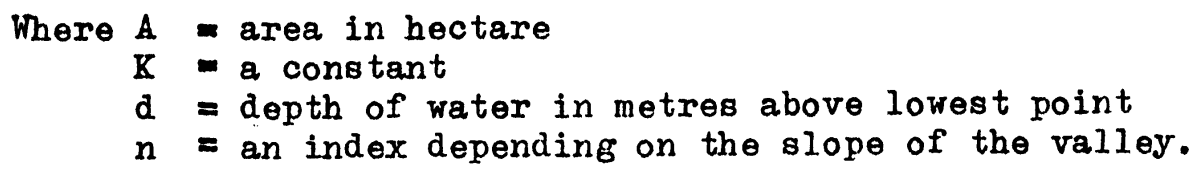

Values for $K$ and $n$ can be computed substituting in the above equation the values of the areas of two contours measured at two depths, thus:

$$
c=\frac{\mathrm{Kd}^{\mathrm{n}+1}}{\mathrm{n}+1}
$$

Where C - Capacity in Cubic Metres

Vol. II-24.

A tracing was made covering the reservoir area and is shown on Drawing No.

The capacity for a 94 metre dam is 656,680 cu metres. (See Drawing No. Vol. II-33).

\section{2. $\quad$ HARI RUD}

\subsection{Assarasum Dam Site Reservoir on the Hari Rud.}

Location: Geographical coordinates as scaled from $7: 50,000$ Geological Survey Advance Maps are N. $34^{\circ} 287^{\prime}$ E $64^{\circ} 594^{\prime}$. The site is about $6 \mathrm{~km}$. downstream from the village of QalaAhangaran. It is covered by air photographs $46 \mathrm{~B} 16880$ and 81 .

Survey: Ground survey was carried out in September 1961 of the dam site area covering $+1.4 \mathrm{~km}^{2}$. It was mapped at $l: 2,000$ with a 10 metre contour $\mathrm{V} .1$ and 1s show on Drawing No. Vol. II-13. The Afghan Geological Survey point 412-c-1 was used as datum for both the dam site survey and the reservoir map. The point was not found in the field so the elevation of the ground was taken as 2,176.6 metres M.S.I.,

Fortunately, within the reservoir area, there were three coordinated points:

$\begin{array}{lcccc}412 C-1 & \text { Photo } & 16879-80 & \mathbf{x} & \mathbf{y} \\ 412 D-1 & " & 20338-39 & 3,815,499.3 & 11,685,242.7 \\ 05646 & " & 20337-38 & 3,823,753.0 & 11,731,134.5 \\ & & 3,822,590.5 & 11,726,061.5\end{array}$

Only photo identification existed for all three points and none of the marks were found in the field.

A double line of levels were run from 412C-1 upstream for a distance of approximately $55 \mathrm{~km}$. Along this levelled line 14 Bench marks were established. Bench marks were not referenced nor are their descriptions recorded. Only photo identification of each point exists. 
A radial triangulation (olotted template) was oarried out using the threo mentioned coordinated points as control. Height oontrol was effeoted by altimetry, employing the double base method of observation. A minimum of five height points were placed in each stereo model. The height points were so placed in the field so that they became pass points in the slotted template lay down. Although this arrangement took more time and care in choosing points in the field it was a great advantage for the plotting. Fifty points were heighted.

Contouring to the $2,370 \mathrm{~m}$. level was carried out in a Zeiss Stereotope with a 10 metre contour V.I. The total area plotted was approximately $300 \mathrm{~km}^{2} \mathrm{which}$ included the Tasrakay Reservoir as well. Both reservoirs are shown on Drawing No. Vol. II-23.

The capacity of the Assarasum Reservoir to $+60 \mathrm{~m}$. level was computed as $593,000,000 \mathrm{~m}^{3}$. (See Drawing No. Vol. II-34).

This reservoir capacity was also computed with the formula as described in (1.5) Lashkar Gah Reservoir Survey, using the areas of the 30 and 60 metre contours. By this method it was found that the capacity differed by $+0.5 \%$ from that which was computed by the classioal method.

\subsection{Tasrakay Dam Site and Reservoir on the Hari Rud}

Location: Geographical coordinates as scaled from the $1: 50,000$ Geological Survey Advance Map are N. $34^{\circ} 32^{\prime} \mathrm{E} 65^{\circ} 25^{\prime}$. The site is situated $1.0 \mathrm{~km}$. downstream from the Hari-Rud-Tasrakay Rud confluence. It is show on air photographs 48-20336 and 37 .

Survey: A large scale map of the dam site area was made using convention al ground survey methods at a scale $1: 2,000$ with 10 metre contours. Area covered at this soale is $1.4 \mathrm{~km}^{2}$. The map is shown on Drawing No. Vol. II-24.

The reservoir map is included in Drawing No. Vol. II-26 with Assarasum Reservoir and the Survey is described under 2.1 .

The reservoir capacity for a dam +68 metres is computed at $474,200,000 \mathrm{~m}^{3}$.

Again the capacity was computed on the formula $A=K \mathrm{~d}^{\mathrm{n}}$ using area values of two contours. The difference in capacity by this method was $+4.0 \%$. (Drawing No. Vol. II-39).

\subsection{Tangi Shah Dam Site and Reservoir on the Kawgan Rud}

Location:

Teographical coordinates as scaled from geological survey advance map 410 EIII are N. $340908^{\prime} \mathrm{E} 63^{\circ} 055^{\prime}$. The site is 11 air km. E.S.E. from Langar Village, and appears in air photographs $41 \mathrm{~A} 21644-45$ and $5513 \rightarrow 58$.

Survey: The dam site and reservoir was surveyed in January and February 1962 under adverse weather conditions. Nuch of the area to be mapped at a large soale has near vertical slopes and they were often covered with snow and ice which made progress slow and treacherous. A map was made by ground survey methods, covering $1.8 \mathrm{~km}^{2}$ at a scale $1: 2,500$ with $10 \mathrm{~V} .1$ contours of the dam site area and is show in Drawing No. Vol. II-15. 
Aerial photographs were height controlled in the field by altimeter to faoilitate plotting. Horizontal control for plotting was effeoted by soaling identifiable points from map sheet 409 FII and laying down a slotted template at 1:50,000 scale. This meant that the entire horizontal control was extrapolated. The map compiled in this manner has recently been checked with advance map 410 HII and the scale compares favourably. Plotting was carried out on a Zeiss Stereotope at one $1: 50,000$ with 10 metre contour V.1.

Absolute elevation was carried into the site by a levelled line from the Afghan Geological Survey BM 409F (Elev. 1207.5). Vol. II-25.

An area of approximately $10 \mathrm{~km}^{2}$ was mapped and is shown in Drawing No.

The reservoir capacity for a dam + 116 metres was computed to be $267,130,000 \mathrm{~m}^{3}$ See Drawing No. Vol. II-44.

2.4 Tagaw Kaza Dam Site and Reservoir on the Hari Rud

Location: Geographical coordinates as scaled from advance map 410 DIII are N. $34^{\circ} 20.4 \mathrm{E} 63^{\circ} 40$. Site is 149 route $\mathrm{km}$. from Herat on the central road to Kabul. It appears in air photographs $41 \mathrm{C} 21610$ and 11.

Survey: A map on a scale $1: 2,000$ with 5 metre V.1. contours was made in the field covering approximately $1.0 \mathrm{~km}^{2}$ in July 1961. A local vertical datum BM "A" assumed 300.00 metres was used.

By interpolation between contrurs, river level at the dam site appears to be $1,468.5$ metres.

The capacity of this site has been computed directly from contours shown on advance map sheets 410 DIII and $410 \mathrm{FI}$. (See Table 17).

2.5 Salma Dam Site and Reservoir on the Hari Rud

Location: Geographical coordinates as scaled fxom advance map sheet 410 FII are $N$. 34019. I 63049.1. The site is situated $1.69 \mathrm{~km}$. east from Herat on the control route to Kabul. It appears in air photographs 43-4047-48.

Survey: An area of approximately $1.0 \mathrm{~km}^{2}$ was mapped in the area of the proposed site. It was mapped by conventional ground methods on a scale $1: 2,000$ with 10 metre V.l. contours. A local vertical datum was used. Station 5 as shown on Drawing No. Vol. II-12 was assumed at 200.00 metres.

Advance map sheets 410 DIV, 410 FII and 411 CIII were used as a basis for the reservoir map. However vertical control was established within the reservoir area by altimetry and new contours were plotted. Contours at 20 metre intervals were plotted in a Zeiss Stereotope to a maximum height of +60 metre above water level at the dam site. By interpolating between contours the river level at the site was found to be $1,530.5$ metres.

The reservoir capacity for a dam +60 metres was computed to be $220,225,000 \mathrm{~m}^{2}$ (See Drawing No. Vol. II-36).

A map of the reservoir is found on Drawing No. Vol. II-26. 


\subsection{Marwa Weir Site on the Hari Rud}

Iooation: Geographical coordinates as scaled from $1: 100,000$ series map 409F are N. $\frac{34^{\circ} 15.4}{1}$ E 62056.61 . The Weir site ia sj tuated anproximately $73 \mathrm{~km}$. from Herat on the road to Obeh and the alignment crosses the river about 220 metres downstream from the most westerly Qala in the village of Rabat-i-Adham.

Survey: A large scale topo survey was carried out in this area to faoilitate design studies. Approximately $0.75 \mathrm{~km}^{2}$ was mapped at $1: 2,000$ scale with $50 \mathrm{~cm}$.contours. The survey was done in March 1963 by conventional survey methods. Elevations are referred to Afghan Ceological Survey BM 409F-7.

A map of the area surveyed can be found in Drawing No. Vol. II-27.

\subsection{Turan Irrigation Design Plot of Representative Area of Herat Valley}

Location: The plot is situated about $37 \mathrm{~km}$. east of Herat on the road to Obeh, and takes in most of the village of Turan and all of the village of Qalia-iNamak. Its southerm boundary is the right bank of the Hari Rud, while the northerm boundary is approximately the Herat-Obeh road between stations C 35 and $C 36$. The boundary breaks away from the road at $\mathrm{C} 36$ and roughly follows just north of a large canal.

The westerm boundary is roughly the $11,458,000 \mathrm{~m}$. grid line while the eastern edge averages about 2,000 metres to the east running slightly west of north.

Survey: A topographical survey was carried out of the area in April 1963 to facilitate irrigation design. The area was mapped at $1: 10,000$ with 1 metre V.l. contours, on the ground by couventional survey methods.

The perimeter was first traversed and staked at distanoes of every 100 metres and levelled. Cross lines spaced 600 metres apart were staked in an east-west direction every 100 metres and levelled.

Two auto reducing tacheometers were used, setting up on the same distance pegs but on different oross lines 600 metres aprt. Then each sighted on the other for line and staff men were sent out along that line at various distances (average 100 metres) until they met. When a line was finished both instmuments moved simultaneously to the next. Applying this method it was found that one man in an average day could map 65 ha. in open flat terrain with a small amount of detail.

The coordinates shown on the plan appear to be the same as those shown on the 1:100,000 map. However, they were determined in the following manner. Coordinates of the culvert on the road near Sta. C36 were scaled from the $1: 100,000$ maps and the traverse is only orientated by compass bearing and correcting for the declinations. The reverse when computed closeci to $1 / 17,000$.

Vertical datum was taken from Sta. 036 which had previously been taken from Afghan Geological Survey BM -7 by the UNSF Irrigation Engineer.

Approximately $8.5 \mathrm{~km}^{2}$ has been mapped and is shown on Drawing No. Vol. VI-3. 
3. $\mathrm{KABUL}$

3.1 Tangi Saidan Dam Site and Reservoir on the Bala Maidan (Kabul)

Location: Geographical coordinates as scaled from 1:50,000 advance map sheet 5 CIO CIII are N $34^{\circ} 24.4^{\prime}$ E $69^{\circ} 06.1^{\prime}$. The site is $16 \mathrm{~km}$. by road from the Demazang petrol station. It is shown inair photographs 64-467 and 77 .

Survey: A large scale topo survey was carried out of the dam site area by conventional methods at a scale $1: 2,000$ with a 10 metre contour V.1. A double levelled line was carried from geological survey BM A8 (elev. 1,821,792). to establieh the vertical datum.

The large scale map is shown in Drawing No. Vol. II-l8 and covers $1.8 \mathrm{~km}^{2}$.

The reservoir was mapped from air photographs. Horizontal control was effected by a subtense bar traverse and vertical control was oarried out by level. The map was plotted in a wild A8 autograph in the Cartographic Institute on a soale 1:25,000 with a 10 metre V.1. contour. Approximately $6 \mathrm{~km}^{2}$ was mapped and is shown in Drawing No. Vol. II-29.

The reservoir capacity for a 60 metre dam is $75,860,000 \mathrm{~m}^{3}$. (See Drawing Vol. II-46).

It will be noticed on the reservoir map that the contours are referred to river bed level at the dam site. For absolute elevations add 1,857 metres.

Approximately $2 \mathrm{~km}$ from the east end of the gorge on the south side of valley there is a low saddle. Its level has been evaluated and the results are shown in Plan No. $T / K / 3$, left in the office of the Afghan Land and Water Authority. $28-55$.

Implications of the col are discussed in Vol. II, Section I, Chapters 20-22 and

3.2 Kajaw Dam Site and Reservoir on the Kajaw Rud

Location: Geographical coordinates can only be given very approximately from the 1:1,000,000 aeronautical chart, as N. 34\%13' E 68028'; aII existing maps are badly in error in this area. The site is approximately 75 air $\mathrm{km}$ W.S.W. from Kabul. It appears in air photographs $62 \mathrm{~A}-9852$ and 53.

Survey: A large scale topo map of the dam site area was started in August 1962 but was not finalized until November. Mapping at a scale 1:2,000 with 10 metre $\nabla .1$. contours covered an area of $1.4 \mathrm{~km}^{2}$. This was done by conventional ground survey methods. The map is contained in Drawing No. Vol. II-17.

The reservoir area was mapped at a scale $1: 50,000$ from air photographs with 20 metre V.I. contours in November 1962. A local vertical datum was used for both maps. BM 1 was assumed 199.453 metres. Horizontal control for the air photographs was effected by a local triangilation scheme consisting of a subtense base expanded into a single quadrilateral. The scheme was orientated by compass only. Since only 4 5 overlaps were involved control was further broken down by radial line hand templates Vertical control for the air photographs was done with altimeters. Plotting was carried out on a Zeiss Stereotope.

The reservoir map covers an area of approximately $15 \mathrm{~km}^{2}$, and is contained in Drawing No. Vol. II-28.

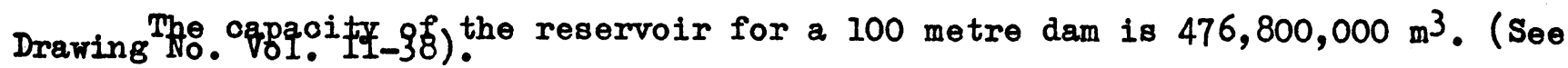




\subsection{Qulbahar Dam Site and Reservoir on the Panhshir River}

Location:

Geographical coordinates with reference to the $1: 1,000,000$ aeronautical chart are N. $35^{\circ} 03^{\prime}$ E $69^{\circ} 17^{\prime}$. The site is situated $1.0 \mathrm{~km}$ upstream from the village of Culbahar.

Survey: This site along with four others on the Ghorband were first investigated in August 1962. Al though none of the sites showed sufficient conclusive evidence to warrant detailed topographic mapping, it was decided that surveys to determine major dimension of dams and initial estimates of reservoir capacities should be carried out.

Surveys of all five sites were executed in the same patterm and were carried out in the following manner:

One or more cross sections of the valley were surveyed on or near each proposed dam axis, to determine roughly the height and width of the dam.

Reservoirs were mapped with the aid of aerial photographs. In all cases the reservoir areas were covered by not more than three overlaps. The photographs were controlled horizontally by open tacheometric traverses and vertical control was effected by altimeters. For the most part the valleys are narrow, and only that portion of the stereo models were controlled. Sufficient height control was established in each reservoir to plot contours by parallax measurements and interpolation. However, all stereo models plotted were found to be relatively free from errar, so it was possible to plot the contours in the stereotope in the normal manner. Reservoirs were plotted at $1: 50,000$ but the contour interval varied from 20 to 50 metres depending on the terrain of the reservoirs. Only preliminaxy capacity curves could be compiled and drawn. All reservoirs as mapped are shown on Drawing No.

Vol. II-30.

The survey datadetermined for the Gulbahar reservoir is as follows:

\begin{tabular}{|c|c|c|c|}
\hline$\theta$ & $\begin{array}{l}\text { I: } 50,000 \\
\text { Assumed water level at dam site } \\
50 \mathrm{~m} . \\
65 \mathrm{ha} . \\
15 \\
10 \mathrm{~km} \text { of Gulbahar-Panjshir } \\
188,290,000 \mathrm{~m}^{3}\end{array}$ & $\begin{array}{l}! \\
! \\
! \\
! \\
! \\
! \\
!\end{array}$ & $\begin{array}{l}148 \text { m. dam } \\
\text { See Drawing No. } \\
\text { Vol. II- } 43 \text { and } \\
\text { Table No. } 10\end{array}$ \\
\hline
\end{tabular}

3.4 Iower Ushturshar Dam Site and Reservoir on the Ghorband

Location: With reference to $1: 1,000,000$ aeronautical chart the geographical coordinates are N. $35^{\circ} 0369^{\circ} 01$. The site is located $24.7 \mathrm{~km}$ from Pul-i-Matak on the road to Char-di-Chorband.

Survey: It was executed in the same way as desoribed in 3.3 (Culbahar Reservoir) shown on Drawing No. Vol. II-30.

As shown by the cross section at the site the maximum feasible height for a dam would be 75 metres. 
Data determined by survey is:

$\begin{array}{ll}\text { Scale } & 1: 50,000 \\ \text { Datum } & \text { Assumed } 100 \text { metres W.I. at } \\ & \text { Ushturshar dam site } \\ \text { Contour V.I. } & 20 \text { metres } \\ \text { Cultivated Land Flooded } & 415 \text { ha. } \\ \text { Road flooded } & 10 \mathrm{~km} \text { approx. } \\ \text { Reservoir Capacity } & 216,580,000 \mathrm{~m}^{3}\end{array}$

$80 \mathrm{~m}$. Dam

See Drawing No.

Vol. II -44 and

Table No. 11

\subsection{Ushturshar Dam Site and Reservoir on the Ghorband}

Location: Geographical coordinates are N. $35^{\circ} 02$ E $68^{\circ} 57$ with referenoe to the $1: 1,000,000$ aeronautical chart. It is $31.6 \mathrm{~km}$ from Pul-i-Matak on the Char-diGhorband road.

(Gulbahar) reservoir. The survey was executed in the same manner as given in 3.3
(Gul

Data determined by survey is:

$\begin{array}{lll}\text { Scale } & 1: 50,000 & ! \\ \text { Datum } & \text { Assumed } 100 \mathrm{~m} . \text { W.L. at } & ! 60 \mathrm{~m} \text {. Dam } \\ & \text { dam site } & ! \text { Seo Drawing No. } \\ \text { Contour V.I. } & 20 \text { metres } & ! \text { Vol. II-45 and } \\ \text { Cultiveted lands flooded } & 270 \mathrm{ha.} & ! \text { Table No. 12 } \\ \text { Farmsteads flooded } & 80 & ! \\ \text { Road Ilooded } & 7 \mathrm{~km} \text { approx. } & ! \\ \text { Reserroir capacity } & 133,250,000 \mathrm{~m} & !\end{array}$

3.6 Junric Chari-diGhorband Dam Site and Reservoir on the Ghorband

Incation: Geosraphical coordinates with reference to $1: 1,000,000$ aeronautical chart are N. $35^{\circ} \mathrm{OI}$ E $68^{\circ} 45^{\prime}$. The site is situated $4.5 \mathrm{~km}$ downstream from Char-di-Ghorband village.

Survey: It is executed in the same manner as described in 3.3 (Gulbahar Reservoir) and is shown on Drawing No. Vol. II-30.

The data determined by survey is:

Scale

Datum

Cultivation flooded

Farmsteads flooded

Road flooded

Reservoir capacity
$1: 50,000$

Assumed 100 m. W.L. at

Ushturshar dam site

Forest 61 ha, crop land

346 ha.

40 (This does not include

dwellings in the village

of Char-di-Ghorband

$10 \mathrm{~km}$ approx.

$161,120,000 \mathrm{~m}^{3}$
$76 \mathrm{~m}$. Dam

1 See Drawing No.

1 Vol. II-46 and

1 Table No. 13

Water level at this site was established by a series of altimetric readings and referred to W.L. at Ushturshar dam site. 


\subsection{Turkman Dam Site and Reservoir on the Turkman}

Location: The geographioal coordinates with reference to the $1: 1,000,000$ aeronautioal chart are N. $34^{057} \mathrm{E}$ 68038. The site is situated $2.3 \mathrm{~km}$ upstream on the Turkman River from the bridge on the Chorband river.

Survey: Tho survey was executed in the same manner as described in 3.3 (Gulbahar Reservoir) and is shown on Drawing No. Vol. II-3.,

Data determined by survey is:

Scale

Datum

Contour V.I.

Cultivation flooded

Farmsteads flooded

Road flooded

Reservoir capaoity
$1: 50,000$

Assumed $100 \mathrm{~m}$. at Ushturshar

dam site W.I.

25 metres

235 ha.

52

$6 \mathrm{~km}$ approx.

$161,120,000 \mathrm{~m}^{3}$
1

l $96 \mathrm{~m}$. Dam

1 See Drawing No.

I. Vol. II-47 and

1. Table No. 14

The datum was established at this site by a series of altimeter readings and are. referred to W.I. at Ushturshar dam site.

The number of farmsteads shown as flooded have only been determined from air photography and no actual count has been taken in the field. Therefore the figures can only be approximate.

\subsection{Other Storage Possibilities Investigated}

A number of other possible storage sites were investigated in varying degrees of detail, ranging from field reconnaissance to solely office studies on air photosraphs and advance copies $1: 50,000$ scale maps.

Four sites were reconnoitred in the Upper Kabul Basin.

1. Puri Site - approximately $20 \mathrm{~km}$ upstream from Jalrez on the Bala Maidan.

2. Sanglokh Site - approximately $13 \mathrm{~km}$ from Jalrez on the Sanglokh River.

3. Shiniz Site - approximately $3 \mathrm{~km}$ upstream on the Shiniz River from the Logar confluence.

4. Nerkh-i-Maidan - on Nerkh-i-Maidan River.

Stream gradients were determined on each of these sites and with the aid of air photographs capacities were roughly determined. The gradients at these sites ranged from $1: 100$ to $1: 20$. Storage possibilities were found to be very limited on all four sites.

Kawgan Rad.

5. Tangi-Azao Site - approximately $15 \mathrm{~km}$ downstream from Qal-i-Shararak on the 
Area and capacity curves were computed from $1: 50,000$ advance copy map sheets 4II, EIII and IV showing 25 metre intermediate contours. From a study of the air photographs as well as having travelled through the reservoir basin the writer thinks that the results shown by the ourve (See Drawing No. Vol. II-40 and Table 15) gives a false impression of the actual capacity. The topography of the reservoir basin indicates that the capacity may be somewhat larger than shown by the advance copy maps. This site was visited by the project's engineering geologist. (See Vol. II, Seotion II, Chapter 21).

6. Barghanak Site - situated on the Rud-i-Gaz about $4 \mathrm{~km}$ east of Barghanak village and is shown in map sheet 415 AII.

Area and capacity curves were computed from the 1:50,000 scale map with 20 metre intermediate contours (See Drawing No. Vol. II-4l, and Table 16). The 20 metre contour as shown on the map does not give a true picture of the configuration of the valley. The river flows in narrcw valley about 30 metres deep so that the ourve possibly shows a larger oapacity actually exists.

The writer visited this site with the project's engineering geologist in July 1963. Results of this visit are discussed in Vol. II, Section I, Ghapter 24.

7. Khash Rud Site - shown in map sheets 422 DIII: and IV.

Area and capacity curves were computed from the advance cony 1:50,000 map sheots using two contours only(See Drawing No. Vol. II-42, and Table 18).

The site is discussed in more detail in Vol. II, Section I, Chapter 25. 


\section{CHAPTER II}

NOTE ON THE NATIONAI MAPP ING PROGRAMRME II AFGHANISTAN

In 1957 Afghanistan launched a nation-wide mapping progrgmme under two separato project areas. The northerm part of approximately $140,000 \mathrm{~km}^{2}$ was contraoted to Technoexport of the U.S.S. R., while the southerm part, of about $500,000 \mathrm{~km}^{2}$, was awarded to Fairchild Aerial Surveys Division of the United States of America.

By late 1959 the entire country had been air photographed at scales ranging from 1840,000 to 115,000. Howerer, the vast majority of the photography averages about $1: 50,000$.

The maps in the northern project area were completed and delivered to the Afghan Geological Survey in November 1960. The compilation scale in the area was 18100,000 series a 1:250,000 scale series was compiled with 100 metre contours plus intermediate 50 metre contours in flat areas.

In addition to these two series a 1:50,000 enlargement series was made directly from the 1:100,000 maps. These sheets were delivered on a transparent base so helio typo prints could be made.

The compilation scale in the southern project is 1:50,000 with basic 50 metre and intermediate 25 metre contours. This series will be a monotone publication. From these 1:50,000 scale maps a 1:100,000 scale series will be produced with the same contour interval. A 1:250,000 scale series will also be compiled with basic 100 metre and supplementary 50 metre and 25 metre contours in flat areas.

At December 1963 the southern part of the mapping project was not complete.

Apart from the above mentioned maps, 1:100,000 scale uncontrolled photo mosaics were produced in the northern area. While in the southern area a 1:100,000 series of controlled mosaics will be produced. The northerm part of the southern area will be covered by 1:50,000 controlled photo mosaics.

Although the mapping project in the southern contract area is not completed as such advance maps are being delivered from the contractor. The maps have been made available to the UNSF project in the form of ozalid prints of machine plots. These advance maps have been of tremendous help, especially in the Farah, Adraskand, Katawaz, Upper Hari Rud and Kabul areas. Seo Drawing Vol. II - 48. 


\section{CHAPTER III}

\section{OTHER MAPS}

Maps for various purposes have been compiled for the project apart from those mentioned in chapter I, mainly sub-catchment maps and basic soil maps.

\section{Sub-Catchment Maps}

Adraskand: This map has been compiled direotly from the 1:50,000 scale advance mape by precision pantograph and reduced to $1: 250,000$.

Although this project has carried out relatively little investigation in this area it was thought that at least one sub-catchment map should be compiled as an example. At the time of compilation it was the only river basin where the majority of advance maps were available.

Kabul. Sub-Catchment maps have been compiled of the upper Kabul tributaries in two parts, the southern streams, Bala Viaidan, Logar and Paghman on one sheet, and the Ghorband, Panjshir and Salang on another.

Only the $1 / 4 "$ to 1 mile Survey of India 1941 series and the $1: 1,000,000$ aeronnutical charts exist in this area as a complete coverage. Both these publications are badiy in error in many places.

This sub-catchment map was compiled mainly from the photo index sheets. Watershed boundaries were drawn directly onto the index sheets with the aid of the air photo con tacti prints. The sheets were then traced and adjusted as far as possible to a common scale and orientatea vith relation to one another. The areas determined from such a map can only be approximate. However, they are more realistic than those taken from any otiler available material. It is almost impossible to locate, for instance, the Kajaw dam site on either the 1/4" series or the aeronautical chart. The catchment area computed for Kajaw dam site from the 1/4" series was approximately $550 \mathrm{~km}^{2}$ while the area measured from the compiled map is more than $4,500 \mathrm{~km}^{2}$. Certainly this latter figure is more consistent with the amount of runoff at the site.

\section{SOIL YAPS}

The following table shows the soil maps which have been drawn and the method of compilation of the basic map:

Area

Farat Valley

Herat Valley

Shindand Basin

Waza Khwa

Ab-I-Is tada

Upper and Middle Namar Valley

Jilga Biver Valley

Panjohir, Ghorband and

Shakar Darya Valley

Part of Logar Valley

\section{Compilation Scale}

1: 50,000

$1: 100,000$

$1: 100,000$

$1: 100,000$

$1: 100,000$

$1: 100,000$

$1: 100,000$ approx.

1860,000 approx.

1860,000 approx.
Method of Compilation

Slotited template laid down on a graphical triangulation. Compiled from Geological Survey Maps.

Compiled from advance copy mapa

$\begin{array}{lllll}11 & 11 & 11 & 11 & 11 \\ 11 & 11 & 11 & 11 & 11 \\ 11 & 11 & 11 & 11\end{array}$

Traced from uncontrolled air photographs.

"

11 i"

n
"

n
11 


\section{SOIL MAPS (cont'd)}

Ohazni Valley

Kabul Valley
1:100,000 approx.

1850,000
Traced from unoontrolled alr photographs.

Radial line template control taken from advance mape 510 CI and 510 CIII.

\section{TABLES OF RESERVOIR AREAS AND CAPACITI CURVES}

\section{Note on Compilation of Tabless}

In general curves that have been compiled from mape with 10 metre contours have been computed at 2 metre intervals. The tables shown here have been condensed to - ither 5 or 10 metre levels. Therefore, the areas will not give exactly the volumen as shown in the table when computed out.

Complete a tables a computed will be left in the files of the Land and Water Authority of Afghanistan.

The area of each plotted contour within the range from minimum to maximum reservolx water level was determined by planimeter. A provisional area curve from planimeter readings was dram. From this area curve intermediate level values were taken and treated to give a mooth mathematioal curve. 


\section{TABLE I}

FARAH RUD

Bakhohabad Dam Site

Numerical Values for Reservoir Area and Capaol ty Curves

Heration

In Metrea

Aseumed Datum

Area in

Cepaoity in

Heotares

Cu. motres

280

0

290

53

300

260

310

955

320

2,225

330

340

4,113

6,860

0

$1,200,000$

$9,100,000$

$40,040,000$

$124,440,000$

$289,720,000$

$572,700,000$

TABLE 2

FARAH ROD

Aliki Nai Dam Site

Numerical Values for Reservoir Area and Capact ty Curves

Elevation

In Metres

892 MSI

900

910

920

930

940

950
Area in

Hectares

0

65

195

410

750

1,319

1,980
Capaoity in

Cu. Metres

$1,625,000$

$14,025,000$

$43,700,000$

$100,600,000$

$202,800,000$

$367,800,000$ 
TABIE 3

FARAR RUD

Lashkar Gah Dam Site

Numerical Values for Reservoir Area and Capacity Curves

El evation

In Metres MSL

1,076 WL at sito

1,080

1,090

1,100

1,110

1,120

1,130

1,140

1,150

1,160

1,170

1,180

1,190

1,200
Area in

Heotares.

0

4

70

145

258

397

580

842

1,207

1,785

2,560

3,420

4,569

5,920
Capaoity in

Cu. Metres

$$
\begin{array}{r}
80,000 \\
3,780,000 \\
14,530,000 \\
34,680,000 \\
67,430,000 \\
116,280,000 \\
187,380,000 \\
289,830,000 \\
439,430,000 \\
656,680,000 \\
955,680,000 \\
1,355,130,000 \\
1,879,580,000
\end{array}
$$

\section{TABLE 4}

HARI RUD

Assarasum Dam Site

Numerical Values for Reservoir Area and Capacity Curves

Elevation

in Metres

$2,167 \cdot 4$ MSL WL at Site

2,170

2,180

2,190

2,200

2,210

2,220

2,230
Area in

Hectares
Capacity in Cu. Metres

$\begin{array}{rr}0 & 0 \\ 7 \cdot 5 & 96,000 \\ 235 & 10,101,000 \\ 620 & 52,571,000 \\ 997 \cdot 5 & 133,426,000 \\ 1,467 \cdot 5 & 255,716,000 \\ 2,015 & 428,981,000 \\ 2,642.5 & 660,376,000\end{array}$




\section{TABLE 5}

\section{HARI RUD}

\section{Tasxakay Dam Sito}

Numerioel Velues for Reservoir Area and Capaoity Curves

\begin{tabular}{lcr} 
Elevation & $\begin{array}{c}\text { Area in } \\
\text { In Metres }\end{array}$ & $\begin{array}{r}\text { Capacity in } \\
\text { Cue Motres }\end{array}$ \\
\cline { 2 - 3 } 2,302 MSI Wh at sito & 0 & 0 \\
2,310 & 12.5 & $1,140,000$ \\
2,320 & 280 & $20,270,000$ \\
2,330 & 505 & $64,620,000$ \\
2,340 & 735 & $131,030,000$ \\
2,350 & 1,000 & $222,760,000$ \\
2,360 & 1,354 & $347,350,000$ \\
2,370 & 1,757 & $474,200,000$
\end{tabular}

\section{TABLE 6}

KAWGAN RUD

Tangi Shah Dam Site

Numerical Values for Reservoir Area and Capaci ty Curves

Elevation

in lietres

1,284 MSL WL at Site

1,290

1,300

1,310

1,320

1,330

1,340

1,350

1,360

1,370

1,380

1,390

1,400
Area in

Hectares

0

5

$17 \cdot 5$

42.5

72.5

97.5

155.0

232.5

297.5

367.5

470.0

572.5

702. 5
Capacity in Cu. Metres

$$
\begin{array}{r}
0 \\
130,000 \\
1,185,000 \\
4,115,000 \\
9,830,000 \\
18,270,000 \\
30,675,000 \\
50,070,000 \\
76,750,000 \\
110,020,000 \\
151,515,000 \\
263,540,000 \\
267,130,000
\end{array}
$$


TABLE 7

HARI RUD

Salme Dam Site

Numerioal Values for Reservoir Area and Capaos ty Curves

\begin{tabular}{lcr}
$\begin{array}{l}\text { El ovation } \\
\text { In Metres }\end{array}$ & $\begin{array}{c}\text { Area in } \\
\text { Heotares }\end{array}$ & \multicolumn{1}{c}{$\begin{array}{c}\text { Capaoity in } \\
\text { Cu. Metres }\end{array}$} \\
\cline { 2 - 3 } 190 WL assumed & 0 & 0 \\
200 & 53 & $2,325,000$ \\
210 & 167.5 & $12,590,000$ \\
220 & 317 & $36,650,000$ \\
230 & 486 & $76,725,000$ \\
240 & 700 & $135,725,000$ \\
250 & 1,000 & $220,225,000$
\end{tabular}

TABLE 8

KABUL RIVER

Tangi Saidan Dam Site

Numerioal Values for Reservoir Area and Capaci ty Curves

\begin{tabular}{lcr} 
Elevation & $\begin{array}{c}\text { Area in } \\
\text { in Metres }\end{array}$ & $\begin{array}{r}\text { Capacity in } \\
\text { Hectares }\end{array}$ \\
\cline { 2 - 3 } $\begin{array}{ccr}\text { Cue Metres } \\
1,857 \text { MSL WL at Site }\end{array}$ & 0 & 0 \\
1,867 & 12.5 & 460,000 \\
1,877 & 59.5 & $3,970,000$ \\
1,887 & 106.3 & $12,230,000$ \\
1,897 & 158.0 & $25,310,000$ \\
1,907 & 240.3 & $44,920,000$ \\
1,917 & 385.6 & $75,860,000$ \\
1,927 & & $116,500,000$
\end{tabular}




\section{TABLE 9}

KABUL RIVER SYSTEM

Kajaw Dam Site

Iumerical Values for Reservoir Area and Capacity Curves

\begin{tabular}{lcr}
$\begin{array}{c}\text { Eleration } \\
\text { In Metres }\end{array}$ & $\begin{array}{c}\text { Area in } \\
\text { Hectares }\end{array}$ & $\begin{array}{r}\text { Capacity in } \\
\text { Cur Metres }\end{array}$ \\
\cline { 3 - 3 } 200 WL assumed & 0 & 0 \\
210 & 15 & 750,000 \\
220 & 42.5 & $3,625,000$ \\
230 & 110 & $11,250,000$ \\
240 & 230 & $28,250,000$ \\
250 & 350 & $57,250,000$ \\
260 & 500 & $99,750,000$ \\
270 & 713 & $160,400,000$ \\
280 & 952.5 & $243,675,000$ \\
290 & 1,165 & $349,550,000$ \\
300 & 1,380 & $476,800,000$
\end{tabular}

TABLE 10

PANJ SHIR RIVER

Gulbahar Dam Site

Numerical Values for Reservoir Area and Capacity Curves

Elevation

in Netres

52 WL assumed

60

70

80

90

100

110

120

130

140

150

160

170

180

190

200
Area in

Hectares

0

1

2

4

9

17.5

29

46

68

99

142. 5

200

268

340

412

490
Capacity in

Cu. Metres

0

40,000

190,000

490,000

$1,140,000$

$2,465,000$

$4,790,000$

$8,540,000$

$14,240,000$

$22,590,000$

$34,665,000$

$51,790,000$

$75,190,000$

$105,590,000$

$143,190,000$

$188,290,000$ 


\section{TABLE 11}

\section{GHORBAND RIVER}

Lower Ushturshar Dam Site

Numerical Values for Reservoir Area and Capacity Curves

Elevation
in Metres

60 WL assumed

70

80

90

100

110

120

130

140

150

160
Area in
Hectares

0
42
95
166
245
316
395
538
737.5
922
$1,077.5$

Capacity in

Cu. Metres

$$
2,100,000
$$$$
8,950,000
$$$$
22,000,000
$$$$
42,550,000
$$$$
70,600,000
$$$$
106,150,000
$$

$152,800,000$

$216,580,000$

$299,550,000$

$399,530,000$

\section{TABIT 12}

\section{GHORBAND RIVER}

Ushturshar Dam Site

Numerical Values for Reservoir Area and Capacity Curves

\begin{tabular}{|c|c|c|}
\hline $\begin{array}{l}\text { Elevation } \\
\text { in Netres }\end{array}$ & $\begin{array}{l}\text { Area in } \\
\text { Hectares }\end{array}$ & $\begin{array}{l}\text { Capacity in } \\
\text { Cu. Metres }\end{array}$ \\
\hline $\begin{array}{l}100 \\
110 \\
120 \\
130 \\
140 \\
150 \\
160\end{array}$ & $\begin{array}{c}0 \\
21 \\
57 \cdot 5 \\
170 \\
330 \\
464 \\
580\end{array}$ & $\begin{array}{r}0 \\
1,050,000 \\
4,975,000 \\
16,350,000 \\
41,350,000 \\
81,050,000 \\
133,250,000\end{array}$ \\
\hline
\end{tabular}


TABLE 13

GHORBAND RIVER

Jungle Char-di-Ghorband Dam Site

Numerical Values for Reservoir Area and Capaoi ty Curves

\begin{tabular}{lcr}
$\begin{array}{l}\text { Elevation } \\
\text { In Metres }\end{array}$ & $\begin{array}{c}\text { Area in } \\
\text { Heotares }\end{array}$ & $\begin{array}{r}\text { Capaoity in } \\
\text { Cu. Metres }\end{array}$ \\
\cline { 2 - 3 } 224 WL assumed & 0 & 0 \\
230 & 19 & 570,000 \\
240 & 52 & $4,120,000$ \\
250 & 95 & $11,470,000$ \\
260 & 148 & $23,620,000$ \\
270 & 222 & $42,120,000$ \\
280 & 331 & $69,770,000$ \\
290 & 458 & $109,280,000$ \\
300 & 580 & $161,120,000$
\end{tabular}

\section{TABLE 14}

TURXOAAT RIVER

Turkman Dam Site

Numerical Values for Reservoir Area and Capacity Curves

Elevation

in Metres

354 assumed

360

370

380

390

400

410

420

430

440

450
Area in

Hectares

0

7
24

52

96

152.5

240

340

420

484

540
Capacity in

Cu. Metres

0

210,000

$1,760,000$

$5,560,000$

$12,960,000$

$25,385,000$

$45,010,000$

$74,010,000$

$112,010,000$

$157,210,000$

$208,410,000$ 


\section{TABLE 15}

\section{KAWGAN RUD}

\section{Tangi Azao Dam Site}

Numexical Values for Reservoir Area and Capacity Curves

Elevation

in Metres

2,251 MSL WL At Site

2,260

2,270

2,280

2,290

2,300

2,310

2,320

2,330

2,340

2,350
Area in

Hectares

0
4
20
55
114
215
386
615
1,040
1,400
1,768

86

615

, 040

1,768
Capacity in Cu. Metres
Cu. Metros

145,000

$1,245,000$

4,870,000

$13,095,000$

$29,270,000$

$58,795,000$

$111,770,000$

$195,545,000$

$317,545,000$

$476,045,000$

\section{TABIE 16}

ADRASTAND

Barghanak Dam Site

Numerical Values for Reservoir Area and Capacity Curves

Elevation

in Metres

1,592

1,602

1,612

1,622

1,632

1,642

1,652

1,62

1,672

1,682
Area in

Hectares

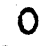

86

165

242

324

410

525

690

907

1,185
Capacity in Cu. Metres

$4,300,000$

$16,000,000$

$37,200,000$

$65,500,000$

$102,200,000$

$148,900,000$

$209,600,000$

$289,500,000$

$394,100,000$ 
TABLE 17

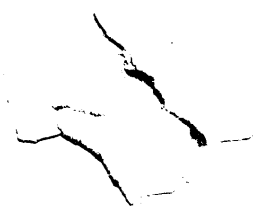

HARI RUD

Tagaw Kaza Dam Site

Mumerioal Values for Reservoir Area and Capaoity Curres

Eleration

in Wetres

0 Aotual elevation $1,468.5$

10 from map

20

30

40

50

60

70
Area in

Hectares

0

1,680

3,240

4,700

6,090

7,460

8,810

1,014
Capaoity in

Gu. Motres

0

$8,500,000$

$33,900,000$

$73,500,000$

$127,300,000$

$157,200,000$

$276,000,000$

$370,900,000$

\section{TABLE 18}

\section{KBASH RUD}

Khash Fud Dam Site

Numerioal Values for Reservoir Area and Capaoity Curves

Elevation

in Metres

942 MSL WL at Site

$$
950
$$

960

970

980

990

1,000
Area in

Hectares

0

17.3

64.0

130.5

213.5

311.2

422.5
Capacity in

Cu. Metres

$$
\begin{array}{r}
692,000 \\
2,757,000 \\
12,482,000 \\
29,682,000 \\
55,912,000 \\
92,597,000
\end{array}
$$

